\title{
Tandem Enyne Metathesis and Claisen Rearrangement: A Versatile Approach to Conjugated Dienes of Variable Substitution Patterns
}

\author{
Daniel A. Clark, Amol A. Kulkarni, Kyle Kalbarczyk, Bryan Schertzer \\ and Steven T. Diver* \\ Department of Chemistry, University at Buffalo, the State University of \\ New York, Amherst, NY, 14260-3000
}

\section{SUPPORTING INFORMATION}

\section{Table of Contents}
A. General Information S1
B. Table 1: Metathesis to form Acyclic Dienes/Claisen.
C. Table 2
1. Metathesis to form Cyclic Dienes/Claisen S12
2. Ireland-Claisen Rearrangement. General Procedure...................S14

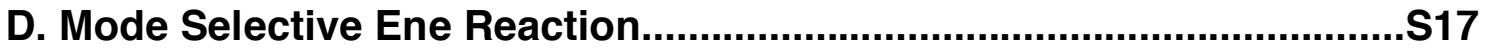

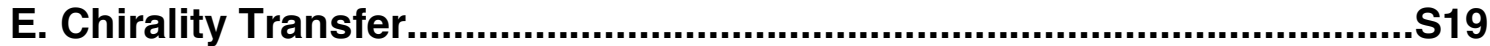

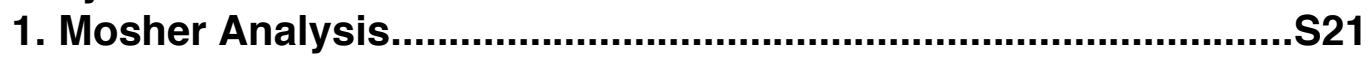

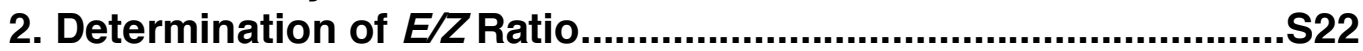
F. Enantiospecific Synthesis of Chiral Cyclohexadiene Diols....................S23
G. ${ }^{1} \mathrm{H}$ and ${ }^{13} \mathrm{C}$ NMR Spectra for New Compounds........................................ 28

\section{General Information}

All reactions were conducted under an argon atmosphere unless otherwise noted. Dichloromethane $\left(\mathrm{CH}_{2} \mathrm{Cl}_{2}\right)$ (alumina), benzene and toluene (alumina + Q5) were drawn from a solvent purifier immediately prior to use. Dry tetrahydrofuran (THF) was obtained from a still ( $\mathrm{Na} /$ benzophenone). Reagent 
grade methanol was used for trituration and the cycloaddition reaction. Ruthenium [1,3-bis-(2,4,6-trimethylphenyl)-2-imidazolidinylidine]dichloro (phenylmethylene)(tricyclohexylphosphine) (Grubbs' second generation catalyst) was obtained from Materia Inc. (Pasadena, CA). 1,5-Cyclooctadiene (COD) was distilled from sodium prior to use. Amines were purchased from Aldrich and distilled from $\mathrm{CaH}_{2}$ and stored over $\mathrm{KOH}$. Polymer grade ethylene gas was obtained from Matheson Tri-gas. Triethylchlorosilane was obtained from Gelest, Inc. and distilled under reduced pressure prior to use. $\mathrm{N}, \mathrm{N}$-dimethylaminopyridine was obtained from Acros. The remaining reagents were purchased from Aldrich and distilled when applicable. Column chromatography was carried out on Bodman industries silica gel 60 (230 - 400 mesh). Thin layer chromatography was developed on glass-backed EM science F254 silica plates and made visible with UV light, iodine, $1.7 \% \mathrm{KMnO}_{4}$ solution in water or Hanessian's stain $\left(5 \% \mathrm{w}_{\mathrm{w}}\right.$ cerium molybdate in $0.72 \mathrm{M} \mathrm{H}_{2} \mathrm{SO}_{4}$ ). ${ }^{1} \mathrm{H}-\mathrm{NMR}$ spectra were recorded at $500 \mathrm{MHz}$ and ${ }^{13} \mathrm{C}$-NMR spectra at $125 \mathrm{MHz}$ in $\mathrm{CDCl}_{3} .{ }^{1} \mathrm{H}$-NMR spectra were referenced on the TMS signal for $\mathrm{CDCl}_{3}$. The ${ }^{13} \mathrm{C}$-NMR spectra were referenced at $77.0 \mathrm{ppm}$ for $\mathrm{CDCl}_{3}$. High resolution mass spectra were obtained using a ThermoFinnigan MAT95XL. Gas chromatography was performed on a Shimadzu GC-17A FID Gas chromatograph (thermal program: $40{ }^{\circ} \mathrm{C}, 4 \mathrm{~min} ; 25^{\circ} \mathrm{C} / \mathrm{min}$ to $280{ }^{\circ} \mathrm{C} ; 280$ ${ }^{\circ} \mathrm{C}, 16.4 \mathrm{~min}$ ) using an Agilent Technologies $19091 \mathrm{~J}-433$ capillary column (30m X $0.250 \mathrm{~mm}, 0.25$ micron). FT-IR spectra were recorded on a Nicolet Impact series 420 IR. Optical rotations were measured on a Jasco DIP-370 polarimeter using the sodium D line at $589 \mathrm{~nm}$ in a $50 \mathrm{~mm}$ cell held at $25^{\circ} \mathrm{C}$. 


\section{Table 1 Acyclic Diene/Ireland Claisen Rearrangement}

(E)-2-Methylene-1-phenyl-oct-3-enyl acetate (2B, metathesis step, entry 1). As reported in the literature: ${ }^{1}$ To an oven-dried $50 \mathrm{~mL}$ Schlenk tube was added 500 $\mathrm{mg}$ of alkyne $2 \mathrm{~A}$ (2.87 mmol), $3.2 \mathrm{~mL}$ of 1-hexene (9 equiv, $25.86 \mathrm{mmol})$, and 3 $\mathrm{mL}$ of dichloromethane. The clear solution was stirred for $5 \mathrm{~min}$ and $122 \mathrm{mg}$ Grubbs' catalyst $1(0.14 \mathrm{mmol}, 5 \mathrm{~mol} \%)$ was added as a single portion. Then reaction was heated at reflux for $18 \mathrm{~h}$, cooled to room temperature, concentrated in vacuo (rotary evaporator), and loaded directly onto a silica gel column ( $3 \times 15$ $\mathrm{cm})$. Elution with $5 \%$ ethyl acetate/hexane gave $500 \mathrm{mg}$ of $\mathbf{2 B}(68 \%)$ as a clear oil. Analytical TLC (10\% ethyl acetate/hexane) $\mathrm{R}_{f}$ 0.36. ${ }^{1} \mathrm{H}$ NMR $(500 \mathrm{MHz}$, $\left.\mathrm{CDCl}_{3}\right) \delta 7.35(\mathrm{~d}, \mathrm{~J}=8.0 \mathrm{~Hz}, 2 \mathrm{H}), 7.30(\mathrm{t}, \mathrm{J}=8.0 \mathrm{~Hz}, 1 \mathrm{H}), 7.26(\mathrm{~d}, \mathrm{~J}=8.0 \mathrm{~Hz}$, 2H), $6.50(\mathrm{~s}, 1 \mathrm{H}), 5.95(\mathrm{~d}, \mathrm{~J}=16.5 \mathrm{~Hz}, 1 \mathrm{H}), 5.67(\mathrm{dt}, \mathrm{J}=16.5 \mathrm{~Hz}, 15.5 \mathrm{~Hz}, 1 \mathrm{H})$, $5.19(\mathrm{~s}, 1 \mathrm{H}), 5.15(\mathrm{~s}, 1 \mathrm{H}), 2.07(\mathrm{~s}, 3 \mathrm{H}), 1.99-1.95(\mathrm{~m}, 2 \mathrm{H}), 1.27-1.15(\mathrm{~m}, 4 \mathrm{H})$, $0.81(\mathrm{t}, \mathrm{J}=7.5 \mathrm{~Hz}, 3 \mathrm{H}) ;{ }^{13} \mathrm{C} \mathrm{NMR}\left(75 \mathrm{MHz}, \mathrm{CDCl}_{3}\right) \delta 169.76,144.12,138.58$, $132.83,128.47,128.29,128.01,127.54,113.95,74.90,32.60,31.12,21.96$, 21.10, 13.76; FT-IR (thin flim, $\mathrm{cm}^{-1}$ ) 3033, 2928, 1743, 1371, 1232, 1024; High resolution ESI molecular ion calcd for $\mathrm{C}_{17} \mathrm{H}_{22} \mathrm{O}_{2} 258.1620$, found 258.1614 $\left(\mathrm{C}_{17} \mathrm{H}_{22} \mathrm{O}_{2}\right)$, error $2.3 \mathrm{ppm}$.

(Z)-4-Benzylidenehex-5-enoic acid (2C, Claisen step, entry 1): To an ovendried $50 \mathrm{~mL}$ Schlenk tube at room temperature was added $2.23 \mathrm{~mL}$ LiHMDS (1M solution in THF), and $260 \mu \mathrm{L} \mathrm{HMPA}$, the yellow solution was cooled to $-78{ }^{\circ} \mathrm{C}$ (dry ice/acetone) and stirred for $5 \mathrm{~min}$. Then, a solution of $300 \mathrm{mg}(1.49 \mathrm{mmol})$ of diene 2B, and $336 \mathrm{mg}(2.23 \mathrm{mmol})$ of TBSCl in $1 \mathrm{~mL}$ of THF were added dropwise via syringe at $-78{ }^{\circ} \mathrm{C}$ over a 5 min period. Orange solution was allowed to stir at $-78{ }^{\circ} \mathrm{C}$ for $15 \mathrm{~min}$ then warmed to room temperature over a period of $1 \mathrm{~h}$. Reaction was then heated to reflux and stirred for a further $2 \mathrm{~h}$ before cooled to room temperature. At this time $3 \mathrm{~mL}$ of $1 \mathrm{M} \mathrm{AcOH}_{(\mathrm{aq})}$ was added and the reaction was stirred at room temperature for $1 \mathrm{~h}$. The reaction was diluted with $15 \mathrm{~mL}$ of dichloromethane, washed $3 \times 15 \mathrm{~mL}$ water, $15 \mathrm{~mL}$ of $1 \mathrm{M} \mathrm{NH}_{4} \mathrm{Cl}$; aqueous layers were extracted with $3 \times 15 \mathrm{~mL}$ of dichloromethane. The organic layers were combined, dried $\left(\mathrm{Na}_{2} \mathrm{SO}_{4}\right)$, filtered, concentrated in vacuo (rotary evaporator), loaded directly onto a silica gel column $(2 \times 10 \mathrm{~cm})$. Gradient elution 10-50\% ethyl acetate/hexane containing $1 \% \mathrm{AcOH}$ gave $247 \mathrm{mg}$ of $2 \mathrm{C} \mathrm{(82 \% )} \mathrm{as} \mathrm{a} \mathrm{slightly}$ yellow oil. Analytical TLC (30\% ethyl acetate/hexane) $\mathrm{R}_{f} 0.14 .{ }^{1} \mathrm{H}$ NMR (500 $\left.\mathrm{MHz}, \mathrm{CDCl}_{3}\right) \delta 11.9(\mathrm{bs}, 1 \mathrm{H}), 7.34(\mathrm{~d}, \mathrm{~J}=8.0 \mathrm{~Hz}, 2 \mathrm{H}), 7.27-7.23(\mathrm{~m}, 3 \mathrm{H}), 6.84$ (dd, J = 17.5 Hz, $11 \mathrm{~Hz}, 1 \mathrm{H}), 5.68(\mathrm{t}, \mathrm{J}=7.5 \mathrm{~Hz}, 1 \mathrm{H}), 5.39(\mathrm{~d}, \mathrm{~J}=17.5 \mathrm{~Hz}, 1 \mathrm{H})$, $5.28(\mathrm{~d}, \mathrm{~J}=11.0 \mathrm{~Hz}, 1 \mathrm{H}), 3.59(\mathrm{~d}, \mathrm{~J}=7.5 \mathrm{~Hz}, 2 \mathrm{H}), 2.65(\mathrm{t}, \mathrm{J}=6.0 \mathrm{~Hz}, 2 \mathrm{H}), 2.62$ (t, J $=6.0 \mathrm{~Hz}, 2 \mathrm{H}) ;{ }^{13} \mathrm{C} \mathrm{NMR}\left(75 \mathrm{MHz}, \mathrm{CDCl}_{3}\right) \delta 179.79,140.45,135.39,131.94$, 129.39, 128.45, 128.33, 126.00, 114.53, 33.50, 33.46, 28.24; FT-IR (thin flim, $\mathrm{cm}^{-}$

${ }^{1}$ Smulik, J.A.; Diver, S.T. J. Org. Chem. 2000, 65,1788-1792. 
$\left.{ }^{1}\right) 3027,2669,1708,1416,1303,909$; High resolution ESI molecular ion calcd for $\mathrm{C}_{14} \mathrm{H}_{16} \mathrm{O}_{2} 216.1150$, found $216.1145\left(\mathrm{C}_{14} \mathrm{H}_{16} \mathrm{O}_{2}\right)$, error $3.1 \mathrm{ppm}$.

(Z)-Methyl 4-benzylidenehex-5-enoate (3C, Claisen step, entry 2): To an ovendried $50 \mathrm{~mL}$ Schlenk tube at room temperature was added $2.23 \mathrm{~mL}$ LiHMDS (1M solution in THF), and $260 \mu \mathrm{L} \mathrm{HMPA}$, the solution was cooled to $-78{ }^{\circ} \mathrm{C}$ (dry ice/acetone) and stirred for $5 \mathrm{~min}$. A solution of $300 \mathrm{mg}(1.49 \mathrm{mmol})$ of diene 2B, and $336 \mathrm{mg}(2.23 \mathrm{mmol})$ of TBSCl in $1 \mathrm{~mL}$ of THF was then added dropwise via syringe at $-78^{\circ} \mathrm{C}$ over a 5 min period. The orange solution was allowed to stir at $-78{ }^{\circ} \mathrm{C}$ for $15 \mathrm{~min}$, warmed to room temperature and stirred at that temperature for $3 \mathrm{~h}$. Next, $25 \mathrm{~mL}$ of water were added and extracted with $3 \times 20 \mathrm{~mL}$ of pentane. The organic layers were combined, concentrated in vacuo (rotary evaporator) to an orange oil that was dissolved in $3 \mathrm{~mL}$ of HMPA, to which 223 $\mathrm{mg}(2.23 \mathrm{mmol})$ of $\mathrm{KHCO}_{3}$, and $210 \mathrm{mg}(2.23 \mathrm{mmol})$ of $\mathrm{KF} \cdot 2 \mathrm{H}_{2} \mathrm{O}$ were added and stirred $30 \mathrm{~min}$ at which time $185 \mu \mathrm{L}(2.98 \mathrm{mmol})$ of Mel were added and reaction was stirred a further $15 \mathrm{~h}$ at room temperature. Next, $30 \mathrm{~mL}$ of water was added and extracted $3 \times 30 \mathrm{~mL}$ of pentane. The organic layers were combined, dried $\left(\mathrm{Na}_{2} \mathrm{SO}_{4}\right)$, filtered, concentrated in vacuo (rotary evaporator), loaded directly onto a silica gel column $(2 \times 10 \mathrm{~cm})$. Elution $10 \%$ ethyl acetate/hexane gave $168 \mathrm{mg}$ of $3 \mathrm{C}(52 \%)$ as a slightly yellow oil. Analytical TLC (10\% ethyl acetate/hexane) $\mathrm{R}_{f}$ 0.37. ${ }^{1} \mathrm{H}$ NMR $\left(500 \mathrm{MHz}, \mathrm{CDCl}_{3}\right) \delta$ 7.37-7.34 $(\mathrm{m}, 2 \mathrm{H}), 7.28-7.26(\mathrm{~m}, 3 \mathrm{H}), 6.81$ (dd, J = 17.5 Hz, 11.0 Hz, 1H), $6.55(\mathrm{~s}, 1 \mathrm{H}), 5.43(\mathrm{~d}, \mathrm{~J}=17.5 \mathrm{~Hz}, 1 \mathrm{H}), 5.24(\mathrm{~d}, \mathrm{~J}$ $=11.0 \mathrm{~Hz}, 1 \mathrm{H}), 3.73(\mathrm{~s}, 3 \mathrm{H}), 2.76(\mathrm{t}, \mathrm{J}=7.5 \mathrm{~Hz}, 2 \mathrm{H}), 2.62(\mathrm{t}, \mathrm{J}=7.5 \mathrm{~Hz}, 2 \mathrm{H}) ;{ }^{13} \mathrm{C}$ NMR $\left(75 \mathrm{MHz}, \mathrm{CDCl}_{3}\right) \delta 173.52,137.07,136.99,133.43,129.85,129.28$, 127.98, 126.73, 115.26, 51.50, 33.43, 28.92; FT-IR (thin flim, $\mathrm{cm}^{-1}$ ) 2951, 1740, 1437, 1236, 1168, 910; High resolution ESI molecular ion calcd for $\mathrm{C}_{14} \mathrm{H}_{16} \mathrm{O}_{2}$ 216.1150, found $216.1145\left(\mathrm{C}_{17} \mathrm{H}_{23} \mathrm{O}_{2}, \mathrm{M}+\mathrm{H}\right)$, error $1.9 \mathrm{ppm}$.

(Z)-6-Phenyl-4-vinylhex-4-enoic acid (4C, Claisen step, entry 3): To an ovendried $50 \mathrm{~mL}$ Schlenk tube at room temperature was added $2.08 \mathrm{~mL}$ LiHMDS (1M solution in THF), and $242 \mu \mathrm{L} \mathrm{HMPA}$, the yellow solution was cooled to $-78{ }^{\circ} \mathrm{C}$ (dry ice/acetone) and stirred for $5 \mathrm{~min}$. Then a solution of $300 \mathrm{mg}(1.39 \mathrm{mmol})$ of diene $4 \mathrm{~B},{ }^{2}$ and $314 \mathrm{mg}(2.08 \mathrm{mmol})$ of $\mathrm{TBSCl}$ in $1 \mathrm{~mL}$ of THF were added dropwise via syringe at $-78{ }^{\circ} \mathrm{C}$ over a 5 min period. The orange solution was allowed to stir at $-78{ }^{\circ} \mathrm{C}$ for $15 \mathrm{~min}$, then warmed to room temperature over a period of $1 \mathrm{~h}$. The reaction was then heated to reflux and stirred for a further $2 \mathrm{~h}$ before being cooled to room temperature. Then $3 \mathrm{~mL}$ of $1 \mathrm{M} \mathrm{AcOH}(\mathrm{aq})$ was added and reaction was stirred at room temperature for $1 \mathrm{~h}$. The reaction was diluted with $15 \mathrm{~mL}$ of dichloromethane, washed $3 \times 15 \mathrm{~mL}$ water, $15 \mathrm{~mL}$ of $1 \mathrm{M} \mathrm{NH}_{4} \mathrm{Cl}$; aqueous layers were extracted with $3 \times 15 \mathrm{~mL}$ of dichloromethane. The organic layers were combined, dried $\left(\mathrm{Na}_{2} \mathrm{SO}_{4}\right)$, filtered, concentrated in vacuo (rotary evaporator), loaded directly onto a silica gel column $(2 \times 10 \mathrm{~cm})$. Gradient elution 
$10-50 \%$ ethyl acetate/hexane containing $1 \% \mathrm{AcOH}$ gave $245 \mathrm{mg}$ of $4 \mathrm{C}(82 \%)$ as a slightly yellow oil. Analytical TLC (30\% ethyl acetate in hexanes) $\mathrm{R}_{f} 0.23$. ${ }^{1} \mathrm{H}$ NMR (500 MHz, $\left.\mathrm{CDCl}_{3}\right) \delta 11.9$ (bs, $\left.1 \mathrm{H}\right), 7.39(\mathrm{~d}, \mathrm{~J}=8.0 \mathrm{~Hz}, 2 \mathrm{H}), 7.33-7.31(\mathrm{~m}$, $3 \mathrm{H}), 6.86(\mathrm{dd}, \mathrm{J}=17.0 \mathrm{~Hz}, 11.0 \mathrm{~Hz}, 1 \mathrm{H}), 6.61(\mathrm{~s}, 1 \mathrm{H}), 5.48(\mathrm{~d}, \mathrm{~J}=17.0 \mathrm{~Hz}, 1 \mathrm{H})$, $5.29(\mathrm{~d}, \mathrm{~J}=11.0 \mathrm{~Hz}, 1 \mathrm{H}), 2.81(\mathrm{t}, \mathrm{J}=6.0 \mathrm{~Hz}, 2 \mathrm{H}), 2.73(\mathrm{t}, \mathrm{J}=6.0 \mathrm{~Hz}, 2 \mathrm{H}) ;{ }^{13} \mathrm{C}$ NMR $\left(75 \mathrm{MHz}, \mathrm{CDCl}_{3}\right) \delta 179.77,136.99,136.82,133.47,130.05,129.35$, 128.03, 126.83, 115.32, 33.47, 28.63; FT-IR (thin flim, $\mathrm{cm}^{-1}$ ) 3022, 2667, 1708, 1417, 1301, 911; High resolution ESI molecular ion calcd for $\mathrm{C}_{13} \mathrm{H}_{14} \mathrm{O}_{2} 202.0994$, found $202.0988\left(\mathrm{C}_{14} \mathrm{H}_{14} \mathrm{O}_{2}\right)$, error $1.4 \mathrm{ppm}$.

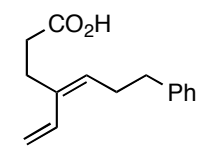

(Z)-7-phenyl-4-vinylhept-4-enoic acid (5C, Claisen step, entry 4): To an ovendried Schlenk tube $(50 \mathrm{~mL})$ equipped with a magnetic stirbar was charged with $0.75 \mathrm{~mL}$ of $1.0 \mathrm{M}$ LiHMDS in THF (0.75 M, 1.5 equiv). This was cooled to $-78{ }^{\circ} \mathrm{C}$ (dry ice acetone bath) for $15 \mathrm{~min}$. $125 \mu \mathrm{L}$ HMPA was added to this solution maintained at $-78{ }^{\circ} \mathrm{C}$. In a separate round bottom flask $(10 \mathrm{~mL})$ was dissolved a mixture of diene ${ }^{5} \mathrm{~B}^{1}$ ( 0.5 mmole, 1.0 equiv) and TBSCl ( 0.75 mmole, 1.5 equiv) in $0.5 \mathrm{~mL}$ of THF. This solution was added dropwise with gas tight syringe into LiHMDS-HMPA solution maintained at $-78{ }^{\circ} \mathrm{C}$ over $3-4$ min. The flask was rinsed with additional $300 \mu \mathrm{L}$ of THF and this solution was added to the solution of the base and HMPA. The reaction mixture was stirred at $-78{ }^{\circ} \mathrm{C}$ for 20 min and then slowly warmed to RT. It was stirred at RT for $24 \mathrm{~h}$. The reaction was quenched by addition of $5 \mathrm{~mL}$ of saturated $\mathrm{NH}_{4} \mathrm{Cl}$ solution. The reaction mixture was poured into a separatory funnel containing $20 \mathrm{~mL}$ of diethyl ether and $20 \mathrm{~mL}$ of saturated $\mathrm{NH}_{4} \mathrm{Cl}$ solution. The organic layer was washed with distilled water $(2 \mathrm{X} 20 \mathrm{~mL})$ and finally with saturated $\mathrm{NH}_{4} \mathrm{Cl}$ solution. The organic layer was separated, dried over anhydrous $\mathrm{Na}_{2} \mathrm{SO}_{4}$ and the diethyl ether was removed in vacuo (rotary evaporator). The pale brown oil thus obtained was redissolved in $5 \mathrm{~mL}$ THF and $0.5 \mathrm{~mL}$ of $1.0 \mathrm{M} \mathrm{HCl}$ was added to it. This was stirred at RT for $45 \mathrm{~min}$. The reaction was quenched by pouring the reaction mixture into a separatory funnel containing $20 \mathrm{~mL}$ distilled water and $20 \mathrm{~mL}$ diethyl ether. The organic layer was washed with distilled water $(2 \times 20 \mathrm{~mL})$ and finally with saturated $\mathrm{NH}_{4} \mathrm{Cl}$ solution $(20 \mathrm{~mL})$. It was dried using anhydrous $\mathrm{Na}_{2} \mathrm{SO}_{4}$ and the solvent removed in vacuo (rotary evaporator). The yellow oil thus obtained was purified by using silica gel flash column chromatography. Gradient elution with $10 \%$ ethyl acetate in hexanes $(100 \mathrm{~mL})$ followed by $20 \%$ ethyl acetate in hexanes $(100 \mathrm{~mL})$ afforded the desired carboxylic acid $\mathbf{5 C}$ as pale yellow oil $(67 \mathrm{mg}, 58 \%$ yield). Analytical tlc: 0.33 (50\% ethyl acetate in hexanes). ${ }^{1} \mathrm{H}$ - NMR $\left(500 \mathrm{MHz}, \mathrm{CDCl}_{3}, \mathrm{ppm}\right) \delta 7.28$ - $7.25(\mathrm{~m}, 2 \mathrm{H}), 7.19-7.16(\mathrm{~m}, 3 \mathrm{H}), 6.63-6.57(\mathrm{~m}, 1 \mathrm{H}), 5.47(\mathrm{t}, \mathrm{J}=7.5 \mathrm{~Hz}, 1 \mathrm{H})$, $5.21(\mathrm{~d}, \mathrm{~J}=17.5 \mathrm{~Hz}, 1 \mathrm{H}), 5.09(\mathrm{~d}, \mathrm{~J}=12.0 \mathrm{~Hz}, 1 \mathrm{H}), 2.67(\mathrm{t}, \mathrm{J}=7.5 \mathrm{~Hz}, 2 \mathrm{H}), 2.55$ $-2.44(\mathrm{~m}, 6 \mathrm{H}) ;{ }^{13} \mathrm{C}-\mathrm{NMR}\left(125 \mathrm{MHz}, \mathrm{CDCl}_{3}, \mathrm{ppm}\right) \delta 180.0,141.6,135.0,131.9$, 
130.3, 128.4, 128.3, 125.9, 113.8, 35.9, 33.5, 29.2, 28.0; FT-IR (thin film, $\mathrm{cm}^{-1}$ ) 2874, 1721, 1545, 913; High-resolution $\mathrm{MS}\left(\mathrm{El}^{+}, \mathrm{m} / \mathrm{z}\right)$ molecular ion calcd for $\mathrm{C}_{15} \mathrm{H}_{18} \mathrm{O}_{2} 230.1301$, found 230.1299, error $1.1 \mathrm{ppm}$.

(Z)-4-Benzylidene-5-methylhex-5-enoic acid (6C, Claisen step, entry 5): To an oven-dried $50 \mathrm{~mL}$ Schlenk tube at room temperature was added $2.08 \mathrm{~mL}$ LiHMDS (1M solution in THF), and $242 \mu \mathrm{L} \mathrm{HMPA}$, yellow solution was cooled to $78{ }^{\circ} \mathrm{C}$ (dry ice/acetone) and stirred for $5 \mathrm{~min}$. A solution of $300 \mathrm{mg}(1.39 \mathrm{mmol})$ of diene $6 \mathrm{~B},{ }^{2}$ and $313 \mathrm{mg}(2.08 \mathrm{mmol})$ of TBSCl in $2 \mathrm{~mL}$ of THF were added dropwise via syringe at $-78{ }^{\circ} \mathrm{C}$ over a 5 min period. The orange solution was stirred at $-78{ }^{\circ} \mathrm{C}$ for $15 \mathrm{~min}$ then allowed to warm to room temperature over a period of $1 \mathrm{~h}$. The reaction mixture was then heated to reflux and stirred for a further $2 \mathrm{~h}$, then cooled to room temperature. Next $3 \mathrm{~mL}$ of $1 \mathrm{M} \mathrm{AcOH}($ aq) added and stirring was continued at room temperature for $1 \mathrm{~h}$. The reaction was diluted with $15 \mathrm{~mL}$ of dichloromethane, washed $3 \times 15 \mathrm{~mL}$ water, $15 \mathrm{~mL}$ of $1 \mathrm{M}$ $\mathrm{NH}_{4} \mathrm{Cl}$; the aqueous layers were back-extracted with $3 \times 15 \mathrm{~mL}$ of dichloromethane. The organics were combined, dried $\left(\mathrm{Na}_{2} \mathrm{SO}_{4}\right)$, filtered, concentrated in vacuo (rotary evaporator) and loaded directly onto a silica gel column $(2 \times 10 \mathrm{~cm})$. Gradient elution with $10-50 \%$ ethyl acetate/hexane containing $1 \% \mathrm{AcOH}$ gave $254 \mathrm{mg}$ of $6 \mathrm{C}(85 \%)$ as an inseparable 5:1 (Z:E) mixture of alkene isomers as a slightly yellow oil. Analytical TLC (30\% ethyl acetate/hexane) $\mathrm{R}_{f}$ 0.12. ${ }^{1} \mathrm{H}$ NMR $\left(500 \mathrm{MHz}, \mathrm{CDCl}_{3}\right.$ ) Major Z: $\delta 7.39(\mathrm{~d}, \mathrm{~J}=7.0$ $\mathrm{Hz}, 2 \mathrm{H}), 7.28$ (t, J= $7.0 \mathrm{~Hz}, 1 \mathrm{H}), 7.21(\mathrm{~d}, \mathrm{~J}=7.0 \mathrm{~Hz}, 2 \mathrm{H}), 6.27(\mathrm{~s}, 1 \mathrm{H}), 5.09$ (s, $1 \mathrm{H}), 4.90(\mathrm{~s}, 1 \mathrm{H}), 2.64(\mathrm{t}, \mathrm{J}=6.5 \mathrm{~Hz}, 2 \mathrm{H}), 2.57(\mathrm{t}, \mathrm{J}=6.5 \mathrm{~Hz}, 2 \mathrm{H}), 1.86(\mathrm{~s}, 3 \mathrm{H})$; Minor E: $\delta 7.39(\mathrm{~d}, \mathrm{~J}=7.0 \mathrm{~Hz}, 2 \mathrm{H}), 7.28(\mathrm{t}, \mathrm{J}=7.0 \mathrm{~Hz}, 1 \mathrm{H}), 7.21(\mathrm{~d}, \mathrm{~J}=7.0 \mathrm{~Hz}$, $2 \mathrm{H}), 6.71(\mathrm{~s}, 1 \mathrm{H}), 5.21(\mathrm{~s}, 1 \mathrm{H}), 5.14(\mathrm{~s}, 1 \mathrm{H}), 2.84(\mathrm{t}, \mathrm{J}=8.0 \mathrm{~Hz}, 2 \mathrm{H}), 2.64(\mathrm{t}, \mathrm{J}=$ $8.0 \mathrm{~Hz}, 2 \mathrm{H}), 2.05(\mathrm{~s}, 3 \mathrm{H}) ;{ }^{13} \mathrm{C} \mathrm{NMR}\left(75 \mathrm{MHz}, \mathrm{CDCl}_{3}\right) \delta 179.60,143.99,142.51$, 137.29, 128.45, 127.97, 126.53, 125.63, 115.45, 33.57, 32.72, 22.15 ; FT-IR (thin flim, $\mathrm{cm}^{-1}$ ) 2966, 1709, 1444, 1298, 901; High resolution ESI molecular ion calcd for $\mathrm{C}_{14} \mathrm{H}_{16} \mathrm{O}_{2} 216.1150$, found $217.1215\left(\mathrm{C}_{14} \mathrm{H}_{17} \mathrm{O}_{2} \mathrm{M}+\mathrm{H}\right)$, error $3.5 \mathrm{ppm}$. An nOe enhancement of the resonance at $\delta 2.05 \mathrm{ppm}$ was observed when the singlet at $\delta$ $6.71 \mathrm{ppm}$ was irradiated. No nOe enhancement was observed when the singlet at $\delta 6.27 \mathrm{ppm}$ was irradiated.

(Z)-Methyl 4-benzylidene-6-ethoxyhex-5-enoate (7C, Claisen step, entry 6): To an oven-dried $100 \mathrm{~mL}$ Schlenk tube at room temperature was added $2.92 \mathrm{~mL}$ LiHMDS (1M solution in THF), and $339 \mu \mathrm{L} \mathrm{HMPA}$, the solution was cooled to -78 ${ }^{\circ} \mathrm{C}$ (dry ice/acetone) and stirred for $5 \mathrm{~min}$. Then, a solution of $480 \mathrm{mg}(1.49$

${ }^{2}$ Smulik, J.A.; Diver, S. T. Org. Lett. 2000, 2, 2271-2274. 
$\mathrm{mmol})$ of diene $7 \mathrm{~B}^{3}$, and $441 \mathrm{mg}(2.23 \mathrm{mmol})$ of TBSCl in $1 \mathrm{~mL}$ of THF were added dropwise via syringe at $-78^{\circ} \mathrm{C}$ over a $5 \mathrm{~min}$ period. The orange solution was allowed to stir at $-78{ }^{\circ} \mathrm{C}$ for $15 \mathrm{~min}$, warmed to room temperature and stirred at that temperature for $30 \mathrm{~h}$. Next, $20 \mathrm{~mL}$ of water were added and extracted with $4 \times 25 \mathrm{~mL}$ of pentane. Organic layers were combined, concentrated in vacuo (rotary evaporator) to an orange oil ( $808 \mathrm{mg}$ ) that was dissolved in $4 \mathrm{~mL}$ of $\mathrm{HMPA}$, to which $293 \mathrm{mg}(2.92 \mathrm{mmol})$ of $\mathrm{KHCO}_{3}$, and $275 \mathrm{mg}(2.92 \mathrm{mmol})$ of $\mathrm{KF} \cdot 2 \mathrm{H}_{2} \mathrm{O}$ were added simultaneously and stirred 30 min at which time $242 \mu \mathrm{L}$ $(3.90 \mathrm{mmol}$ ) of Mel were added and the reaction was stirred a further $15 \mathrm{~h}$ at room temperature. A $30 \mathrm{~mL}$ of water was added and the aqueous layer was extracted $4 \times 30 \mathrm{~mL}$ of pentane. The organic layers were combined, dried $\left(\mathrm{Na}_{2} \mathrm{SO}_{4}\right)$, filtered, concentrated in vacuo (rotary evaporator), loaded directly onto a deactivated $(5 \%$ triethylamine) silica gel column $(2 \times 10 \mathrm{~cm})$. Gradient elution $5-10 \%$ ethyl acetate/hexane gave $305 \mathrm{mg}$ of $7 \mathrm{C}(60 \%)$ as an inseparable 1.3:1 $(E: Z)$ mixture of alkene isomers as a slightly yellow oil. Analytical TLC (10\% ethyl acetate/hexane) $\mathrm{R}_{f}$ 0.15. ${ }^{1} \mathrm{H}$ NMR $\left(500 \mathrm{MHz}, \mathrm{CDCl}_{3}\right.$ ) Major E: $\delta$ 7.26-7.19 (m, $3 \mathrm{H}), 7.14-7.11(\mathrm{~m}, 2 \mathrm{H}), 6.67(\mathrm{~d}, \mathrm{~J}=13.0 \mathrm{~Hz}, 1 \mathrm{H}), 6.14(\mathrm{~s}, 1 \mathrm{H}), 5.96(\mathrm{~d}, \mathrm{~J}=13.0$ $\mathrm{Hz}, 1 \mathrm{H}$ ), $3.74(\mathrm{q}, \mathrm{J}=14.0 \mathrm{~Hz}, 7.0 \mathrm{~Hz}, 2 \mathrm{H}), 3.64(\mathrm{~s}, 3 \mathrm{H}), 2.59-2.53(\mathrm{~m}, 2 \mathrm{H}), 2.50$ (t, J = 7.5 Hz, 2H), $1.21(\mathrm{t}, \mathrm{J}=7.5 \mathrm{~Hz}, 3 \mathrm{H})$; Minor Z: $\delta$ 7.26-7.19 (m, 3H), 7.14$7.11(\mathrm{~m}, 2 \mathrm{H}), 6.15(\mathrm{~s}, 1 \mathrm{H}), 5.93(\mathrm{~d}, \mathrm{~J}=7.0 \mathrm{~Hz}, 1 \mathrm{H}), 5.16(\mathrm{~d}, \mathrm{~J}=7.0 \mathrm{~Hz}, 1 \mathrm{H}), 3.80$ (q, J = 14.0 Hz, 7.0 Hz, 2H), 3.62 (s, 3H), $2.80(\mathrm{t}, \mathrm{J}=7.5 \mathrm{~Hz}, 2 \mathrm{H}), 2.59-2.53(\mathrm{~m}$, $2 \mathrm{H}), 1.22$ (t, $\mathrm{J}=7.5 \mathrm{~Hz}, 3 \mathrm{H}) ;{ }^{13} \mathrm{C}$ NMR $\left(75 \mathrm{MHz}, \mathrm{CDCl}_{3}\right) \delta 178.11,173.64$, $149.37,146.54,138.13,137.88,136.09,134.84,129.13,129.00,128.05,127.89$, $127.00,126.14,126.12,125.00,103.86,102.74,68.74,65.67,51.54,51.29$, 34.26, 33.72, 32.94, 29.91, 15.15, 14.77; FT-IR (thin flim, $\mathrm{cm}^{-1}$ ) 2942, 1743, 1633, 1440, 1236, 1175; High resolution ESI molecular ion calcd for $\mathrm{C}_{16} \mathrm{H}_{20} \mathrm{O}_{3}$ 260.1412, found $283.1305\left(\mathrm{C}_{16} \mathrm{H}_{20} \mathrm{O}_{3}, \mathrm{M}+\mathrm{Na}\right)$, error $1.6 \mathrm{ppm}$.

Scheme S1. Saponification of 8B

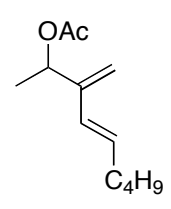

$8 B$

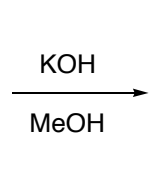

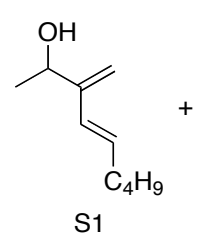

S1

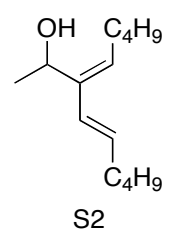

S2

(E)-3-Methylene-non-4-en-2-yl acetate (8B, metathesis step, entry 7): To an oven-dried $50 \mathrm{~mL}$ Schlenk tube was added $150 \mathrm{mg}$ of alkyne $\mathbf{8 A}(1.34 \mathrm{mmol}), 1.5$ $\mathrm{mL}$ of 1 -hexene (9 equiv, $12.05 \mathrm{mmol}$ ), and $3 \mathrm{~mL}$ of dichloromethane. The clear solution was stirred for $5 \mathrm{~min}$ and $57 \mathrm{mg}$ Grubbs' catalyst 1 (0.07 mmol, $5 \mathrm{~mol} \%)$ was added as a single portion. The reaction was heated at reflux for $18 \mathrm{~h}$, cooled to room temperature, concentrated in vacuo (rotary evaporator), and loaded

${ }^{3}$ Giessert, A. J.; Snyder, L.; Markham, J.; Diver, S. T. Org. Lett. 2003, 5, 17931796. 
directly onto a silica gel column $(3 \times 15 \mathrm{~cm})$. Elution with $5 \%$ ethyl acetate/hexane gave $240 \mathrm{mg}$ of $\mathbf{8 B}(91 \%)$ as a clear oil. The product was determined to be greater than $90 \%$ pure by proton NMR. This product was fully characterized as the alcohol $\mathbf{S 1}$. An analytically pure sample was obtained by saponification $(\mathrm{KOH} / \mathrm{MeOH}, \mathrm{rt}, 1 \mathrm{~h})$ and separation of the by-product by chromatography on silica gel $(2 \times 10 \mathrm{~cm})$. (10\% ethyl acetate/hexanes). Alcohol S1: Analytical TLC (10\% ethyl acetate/hexane) $\mathrm{R}_{f} \quad 0.15,{ }^{1} \mathrm{H}$ NMR $(500 \mathrm{MHz}$, $\left.\mathrm{CDCl}_{3}\right) \delta 6.00(\mathrm{~d}, \mathrm{~J}=16.0 \mathrm{~Hz}, 1 \mathrm{H}), 5.78(\mathrm{dt}, \mathrm{J}=16.0 \mathrm{~Hz}, 14 \mathrm{~Hz}, 1 \mathrm{H}), 5.09$ (s, $1 \mathrm{H}), 4.96(\mathrm{~s}, 1 \mathrm{H}), 4.53(\mathrm{q}, \mathrm{J}=6.5 \mathrm{~Hz}, 1 \mathrm{H}), 2.07(\mathrm{q}, \mathrm{J}=6.5 \mathrm{~Hz}, 2 \mathrm{H}), 1.69(\mathrm{bs}, 1 \mathrm{H})$, 1.38-1.27 (m, 7H), $0.87(\mathrm{t}, \mathrm{J}=7.0,3 \mathrm{H}) ;{ }^{13} \mathrm{C}$ NMR $\left(75 \mathrm{MHz}, \mathrm{CDCl}_{3}\right) \delta 150.31$, 131.34, 129.11, 110.56, 67.75, 32.75, 31.41, 22.79, 22.21, 13.87; FT-IR (thin flim, $\mathrm{cm}^{-1}$ ) 3328, 2966, 2633, 2874, 1466, 1374, 985; High resolution ESI molecular ion calcd for $\mathrm{C}_{10} \mathrm{H}_{17} \mathrm{O}(\mathrm{M}-\mathrm{H})$ 153.1274, found $153.1273\left(\mathrm{C}_{10} \mathrm{H}_{17} \mathrm{O} ; \mathrm{M}-\mathrm{H}\right)$, error $0.1 \mathrm{ppm}$. By-Product S2: Analytical TLC (10\% ethyl acetate/hexane) $\mathrm{R}_{t}$ 0.17. ${ }^{1} \mathrm{H}$ NMR $\left(500 \mathrm{MHz}, \mathrm{CDCl}_{3}\right) \delta 6.19(\mathrm{~d}, \mathrm{~J}=16.5 \mathrm{~Hz}, 1 \mathrm{H}), 5.74$ (dt, $\mathrm{J}=16.5$ $\mathrm{Hz}, 14 \mathrm{~Hz}, 1 \mathrm{H}), 5.53(\mathrm{t}, \mathrm{J}=8.0 \mathrm{~Hz}, 1 \mathrm{H}), 4.53(\mathrm{q}, \mathrm{J}=4.5 \mathrm{~Hz}, 1 \mathrm{H}), 2.15-2.09(\mathrm{~m}$, $4 \mathrm{H}), 1.46$ (bs, $1 \mathrm{H}), 1.39-1.27(\mathrm{~m}, 11 \mathrm{H}), 0.89(\mathrm{t}, \mathrm{J}=7.5,3 \mathrm{H}), 0.87(\mathrm{t}, \mathrm{J}=7,3 \mathrm{H})$; ${ }^{13} \mathrm{C}$ NMR $\left(75 \mathrm{MHz}, \mathrm{CDCl}_{3}\right) \delta 140.13,131.60,126.54,124.49,68.83,33.29$, 31.94, 31.65, 27.04, 22.80, 22.37, 22.24, 13.94, 13.90; FT-IR (thin flim, $\mathrm{cm}^{-1}$ ) 3368, 2960, 2874, 2854, 1466, 966; High resolution ESI molecular ion calcd for $\mathrm{C}_{14} \mathrm{H}_{26} \mathrm{O} 210.1986$, found $210.1976\left(\mathrm{C}_{14} \mathrm{H}_{26} \mathrm{O}\right)$, error $0.9 \mathrm{ppm}$.

(4Z, 5E)-4-Ethylidenedec-5-enoic acid (8C, Claisen step, entry 7): To an ovendried $50 \mathrm{~mL}$ Schlenk tube at room temperature was added $2.3 \mathrm{~mL}$ LiHMDS (1M solution in THF), $266 \mu \mathrm{L}$ HMPA, yellow solution was cooled to $-78{ }^{\circ} \mathrm{C}$ (dry ice/acetone) and stirred for $5 \mathrm{~min}$. A solution of $300 \mathrm{mg}(1.53 \mathrm{mmol})$ of diene $8 \mathrm{~B}$, and $313 \mathrm{mg}(2.3 \mathrm{mmol})$ of $\mathrm{TBSCl}$ in $1 \mathrm{~mL}$ of THF were added dropwise via syringe at $-78^{\circ} \mathrm{C}$ over a 5 min period. The orange solution was allowed to stir at $-78{ }^{\circ} \mathrm{C}$ for $15 \mathrm{~min}$, then warmed to room temperature and stirred at that temperature for $30 \mathrm{~h}$. Then $3 \mathrm{~mL}$ of $1 \mathrm{M} \mathrm{AcOH}_{(\mathrm{aq})}$ was added and reaction was stirred at room temperature for $1 \mathrm{~h}$. The reaction was diluted with $15 \mathrm{~mL}$ of dichloromethane, washed $3 \times 15 \mathrm{~mL}$ water, $15 \mathrm{~mL}$ of $1 \mathrm{M} \mathrm{NH}_{4} \mathrm{Cl}$; aqueous layers were extracted with $3 \times 15 \mathrm{~mL}$ of dichloromethane. The organic layers were combined, dried $\left(\mathrm{Na}_{2} \mathrm{SO}_{4}\right)$, filtered, concentrated in vacuo (rotary evaporator) and loaded directly onto a silica gel column $(2 \times 10 \mathrm{~cm})$. Gradient elution 10-50\% ethyl acetate/hexane gave $182 \mathrm{mg}$ of $\mathbf{8 C}(61 \%)$ as a slightly yellow oil. Analytical TLC (30\% ethyl acetate/hexane) $\mathrm{R}_{f} 0.12,{ }^{1} \mathrm{H}$ NMR $\left(500 \mathrm{MHz}, \mathrm{CDCl}_{3}\right) \delta 6.29$ (d, J $=15.5 \mathrm{~Hz}, 1 \mathrm{H}), 5.67(\mathrm{dt}, \mathrm{J}=15.5 \mathrm{~Hz}, 14.5 \mathrm{~Hz}, 1 \mathrm{H}), 5.35$ (q, J = $14.5 \mathrm{~Hz}, 7 \mathrm{~Hz}$, $1 \mathrm{H}), 2.48(\mathrm{~s}, 3 \mathrm{H}), 2.14-2.09(\mathrm{~m}, 2 \mathrm{H}), 1.69(\mathrm{~d}, \mathrm{~J}=7 \mathrm{~Hz}, 3 \mathrm{H}), 1.39-1.29(\mathrm{~m}, 6 \mathrm{H})$, 0.89 (t, J=7 Hz, 3H); ${ }^{13} \mathrm{C}$ NMR $\left(75 \mathrm{MHz}, \mathrm{CDCl}_{3}\right) \delta 179.06,135.08,130.48$, 125.17, 122.76, 33.50, 33.03, 31.71, 29.02, 22.28, 13.93, 13.04; FT-IR (thin flim, $\mathrm{cm}^{-1}$ ) 2920, 1698, 1453, 958; High resolution ESI molecular ion calcd for $\mathrm{C}_{12} \mathrm{H}_{20} \mathrm{O}_{2}$ 196.1463, found $197.1536\left(\mathrm{C}_{12} \mathrm{H}_{21} \mathrm{O}_{2}, \mathrm{M}+\mathrm{H}\right)$, error $0.1 \mathrm{ppm}$. 
(4Z, 5E)-4-Benzylidenedec-5-enoic acid (9C, Claisen step, entry 8): To an oven-dried $50 \mathrm{~mL}$ Schlenk tube at room temperature was added $2.33 \mathrm{~mL}$ LiHMDS (1M solution in THF), and $270 \mu \mathrm{L}$ HMPA, yellow solution was cooled to $78{ }^{\circ} \mathrm{C}$ (dry ice/acetone) and stirred for $5 \mathrm{~min}$. Subsequently a solution of $400 \mathrm{mg}$ $(1.55 \mathrm{mmol})$ of diene $9 \mathrm{~B}$, and $351 \mathrm{mg}(2.33 \mathrm{mmol})$ of TBSCl in $1 \mathrm{~mL}$ of THF were added dropwise via syringe at $-78^{\circ} \mathrm{C}$ over a $5 \mathrm{~min}$ period. The orange solution was allowed to stir at $-78{ }^{\circ} \mathrm{C}$ for $15 \mathrm{~min}$, then warmed to room temperature and stirred at that temperature for $3 \mathrm{~h}$. Next, $20 \mathrm{~mL}$ of diethyl ether and $2 \mathrm{~mL}$ of brine were added. The ether layer was washed $2 \times 5 \mathrm{~mL}$ with water. The aqueous layers were combined and extracted with $20 \mathrm{~mL}$ ether. The organic layers were combined, concentrated in vacuo (rotary evaporator) to an orange oil that was dissolved in $3 \mathrm{~mL}$ THF and $1 \mathrm{~mL}$ or $1 \mathrm{M} \mathrm{HCl}_{\text {(aq) }}$ the orange solution was stirred at room temperature for $1 \mathrm{~h}$. The reaction was poured into $20 \mathrm{~mL}$ of ethyl acetate, and washed with $3 \mathrm{~mL}$ sat. $\mathrm{NH}_{4} \mathrm{Cl}$. The organic layers were combined, dried $\left(\mathrm{Na}_{2} \mathrm{SO}_{4}\right)$, filtered, concentrated in vacuo (rotary evaporator), loaded directly onto a silica gel column $(2 \times 10 \mathrm{~cm})$. Gradient elution $10-30 \%$ ethyl acetate/hexane gave $318 \mathrm{mg}$ of $9 \mathrm{C}(80 \%)$ as a slightly yellow oil. Analytical TLC (30\% ethyl acetate/hexane) $\mathrm{R}_{f}$ 0.12. ${ }^{1} \mathrm{H}$ NMR $\left(500 \mathrm{MHz}, \mathrm{CDCl}_{3}\right) \delta$ 7.33-7.30 $(\mathrm{m}, 2 \mathrm{H})$, 7.25$7.20(\mathrm{~m}, 3 \mathrm{H}), 6.45(\mathrm{~d}, \mathrm{~J}=15.5 \mathrm{~Hz}, 1 \mathrm{H}), 6.38(\mathrm{~s}, 1 \mathrm{H}), 5.87(\mathrm{dt}, \mathrm{J}=15.5 \mathrm{~Hz}, 14.5$ $\mathrm{Hz}, 1 \mathrm{H}), 2.71(\mathrm{t}, \mathrm{J}=8.0 \mathrm{~Hz}, 2 \mathrm{H}), 2.62(\mathrm{t}, \mathrm{J}=8.0 \mathrm{~Hz}, 2 \mathrm{H}), 2.14-2.09(\mathrm{~m}, 2 \mathrm{H}), 1.41-$ $1.29(\mathrm{~m}, 4 \mathrm{H}), 0.89(\mathrm{t}, \mathrm{J}=7.0 \mathrm{~Hz}, 3 \mathrm{H}) ;{ }^{13} \mathrm{C} \mathrm{NMR}\left(75 \mathrm{MHz}, \mathrm{CDCl}_{3}\right) \delta 179.34$, $137.51,136.87,132.85,129.35,128.02,127.60,126.70,125.50,33.67,32.88$, 31.49, 29.59, 22.23, 13.87; FT-IR (thin flim, $\mathrm{cm}^{-1}$ ) 2926, 1708, 1444, 976; High resolution ESI molecular ion calcd for $\mathrm{C}_{17} \mathrm{H}_{22} \mathrm{O}_{2} 258.1620$, found 259.1688 $\left(\mathrm{C}_{17} \mathrm{H}_{23} \mathrm{O}_{2}, \mathrm{M}+\mathrm{H}\right)$, error $1.4 \mathrm{ppm}$.

(E)-3-Methylene-1-phenyl-non-4-en-2-yl acetate (10B, metathesis step, entry 9): To an oven-dried $50 \mathrm{~mL}$ Schlenk tube was added $400 \mathrm{mg}$ of alkyne 4A (2.13 $\mathrm{mmol}$ ), $2.4 \mathrm{~mL}$ of 1 -hexene (9 equiv, $19.15 \mathrm{mmol}$ ), and $6 \mathrm{~mL}$ of dichloromethane. The clear solution was stirred for $5 \mathrm{~min}$ and $90 \mathrm{mg}$ Grubbs' catalyst $1(0.11 \mathrm{mmol}$, $5 \mathrm{~mol} \%$ ) was added as a single portion. The reaction was heated at reflux for 18 $\mathrm{h}$, cooled to room temperature, concentrated in vacuo (rotary evaporator), and loaded directly on to a silica gel column $(2 \times 10 \mathrm{~cm})$. Elution with $5 \%$ ethyl acetate/hexane gave $539 \mathrm{mg}$ of 10B $(93 \%)$ as a clear oil. Analytical TLC $(10 \%$ ethyl acetate/hexane) $\mathrm{R}_{f}$ 0.35. ${ }^{1} \mathrm{H}$ NMR $\left(500 \mathrm{MHz}, \mathrm{CDCl}_{3}\right) \delta 7.35$ (d, J = 8.0 Hz, $2 \mathrm{H}), 7.30(\mathrm{t}, \mathrm{J}=8.0 \mathrm{~Hz}, 1 \mathrm{H}), 7.26(\mathrm{~d}, \mathrm{~J}=8.0 \mathrm{~Hz}, 2 \mathrm{H}), 6.05(\mathrm{~d}, \mathrm{~J}=16.0 \mathrm{~Hz}, 1 \mathrm{H})$, 5.91 (dt, J = $16.0 \mathrm{~Hz}, 14,1 \mathrm{H}$ ), 5.68 (dd, J = 8.0 Hz, $5 \mathrm{~Hz}, 1 \mathrm{H}$ ), $5.06(\mathrm{~s}, 1 \mathrm{H}), 5.01$ (s, 1H), 3.07 (dd, J = 5.0 Hz, 1H), $2.96(\mathrm{dd}, \mathrm{J}=8.0 \mathrm{~Hz}, 1 \mathrm{H}), 2.17-2.13(\mathrm{~m}, 2 \mathrm{H})$, $2.03(\mathrm{~s}, 3 \mathrm{H}), 1.45-1.34(\mathrm{~m}, 4 \mathrm{H}), 0.95(\mathrm{t}, \mathrm{J}=8.0 \mathrm{~Hz}, 3 \mathrm{H}) ;{ }^{13} \mathrm{C} \mathrm{NMR}(75 \mathrm{MHz}$, $\left.\mathrm{CDCl}_{3}\right) \delta 169.95,144.61,137.55,131.87,129.32,128.67,128.17,126.46$, 113.14, 74.33, 40.63, 32.81, 31.36, 22.23, 21.08, 13.93; FT-IR (thin flim, $\mathrm{cm}^{-1}$ ) 
$3029,2927,1745,1369,1234,1029$; High resolution ESI molecular ion calcd for $\mathrm{C}_{18} \mathrm{H}_{24} \mathrm{O}_{2} 272.1856$, found $273.1849\left(\mathrm{C}_{18} \mathrm{H}_{25} \mathrm{O}_{2} \mathrm{M}+\mathrm{H}\right)$, error $2.7 \mathrm{ppm}$.

(4Z, 5E)-4-(2-Phenyethylidene)dec-5-enoic acid (10C, Claisen step, entry 9): To an oven-dried $50 \mathrm{~mL}$ Schlenk tube at room temperature was added $2.76 \mathrm{~mL}$ LiHMDS (1M solution in THF), and $320 \mu \mathrm{L} \mathrm{HMPA}$, yellow solution was cooled to $78{ }^{\circ} \mathrm{C}$ (dry ice/acetone) and stirred for $5 \mathrm{~min}$. Then, a solution of $500 \mathrm{mg}(1.84$ $\mathrm{mmol})$ of diene $10 \mathrm{~B}$, and $416 \mathrm{mg}(2.75 \mathrm{mmol})$ of TBSCl in $1 \mathrm{~mL}$ of THF were added dropwise via syringe at $-78{ }^{\circ} \mathrm{C}$ over a $5 \mathrm{~min}$ period. The orange solution was allowed to stir at $-78{ }^{\circ} \mathrm{C}$ for $15 \mathrm{~min}$, then warmed to room temperature and stirred at that temperature for $30 \mathrm{~h}$. Then $3 \mathrm{~mL}$ of $1 \mathrm{M} \mathrm{AcOH}_{(\text {aq) }}$ was added and reaction was stirred at room temperature for $1 \mathrm{~h}$. The reaction was diluted with $15 \mathrm{~mL}$ of dichloromethane, washed $3 \times 15 \mathrm{~mL}$ water, $15 \mathrm{~mL}$ of $1 \mathrm{M} \mathrm{NH}_{4} \mathrm{Cl}$; aqueous layers were extracted with $3 \times 15 \mathrm{~mL}$ of dichloromethane. The organic layers were combined, dried $\left(\mathrm{Na}_{2} \mathrm{SO}_{4}\right)$, filtered, concentrated in vacuo (rotary evaporator), loaded directly onto a silica gel column $(2 \times 10 \mathrm{~cm})$. Gradient elution $10-30 \%$ ethyl acetate/hexane gave $425 \mathrm{mg}$ of $10 \mathrm{C}(85 \%)$ as a slightly yellow oil. Analytical TLC (30\% ethyl acetate/hexane) $\mathrm{R}_{f} 0.15 .{ }^{1} \mathrm{H} \mathrm{NMR}\left(500 \mathrm{MHz}, \mathrm{CDCl}_{3}\right) \delta$ 7.27-7.23 (m, 2H), 7.17-7.13 (m, 3H), $6.39(\mathrm{~d}, \mathrm{~J}=16.0 \mathrm{~Hz}, 1 \mathrm{H}), 5.76(\mathrm{dt}, \mathrm{J}=16.0$ $\mathrm{Hz}, 15 \mathrm{~Hz}, 1 \mathrm{H}), 5.49(\mathrm{t}, \mathrm{J}=7.5,1 \mathrm{H}), 3.48(\mathrm{~d}, \mathrm{~J}=7.5,2 \mathrm{H}), 2.56-2.50(\mathrm{~m}, 4 \mathrm{H}), 2.15-$ $2.11(\mathrm{~m}, 2 \mathrm{H}), 1.43-1.23(\mathrm{~m}, 4 \mathrm{H}), 0.89(\mathrm{t}, \mathrm{J}=7.0 \mathrm{~Hz}, 3 \mathrm{H}) ;{ }^{13} \mathrm{C} \mathrm{NMR}(75 \mathrm{MHz}$, $\left.\mathrm{CDCl}_{3}\right) \delta 180.05,140.85,135.22,131.72,128.38,128.32,126.79,125.87$, 125.17, 33.69, 33.45, 33.02, 31.59, 29.08, 22.26, 13.91; FT-IR (thin flim, $\mathrm{cm}^{-1}$ ) 3032, 2926, 1709, 1254, 837; High resolution ESI molecular ion calcd for $\mathrm{C}_{18} \mathrm{H}_{24} \mathrm{O}_{2} 272.1772$, found 272.1771 $\left(\mathrm{C}_{17} \mathrm{H}_{23} \mathrm{O}_{2}, \mathrm{M}+\mathrm{H}\right)$, error $0.4 \mathrm{ppm}$.

(E)-4-Methylene-1-phenyldec-5-en-3-yl acetate (11B, metathesis step, entry 9): To a dry $100 \mathrm{~mL}$ Schlenk tube was added a solution of $40 \mathrm{~mL}$ of dichloromethane and $405 \mathrm{mg}(2.0 \mathrm{mmol})$ of racemic acetate 5A. To this mixture was added in $2.48 \mathrm{~mL}(10 \mathrm{mmol})$ of 1 -hexene. Exactly $0.9 \mathrm{mg}(0.1 \mathrm{mmol})$ of catalyst 1 was added, followed immediately by capping the schlenk tube with a cold finger condenser. The reaction vessel was then placed in an oil bath allowing the reaction to stir at reflux for $26 \mathrm{~h}$ (completion determined disappearance of $\mathbf{5 A}$ by $\mathrm{GC}$ at $13.13 \mathrm{~min}$ ). Any remaining catalyst was inactivated by adding $0.048 \mathrm{~mL}(0.5 \mathrm{mmol})$ of ethyl vinyl ether, refluxing for $1 \mathrm{~h}$ and then allowing the reaction vessel to cool to room temperature. The solution was then concentrated in vacuo (rotary evaporator) The compound was purified by flash column chromatography on silica $(15 \times 2.5 \mathrm{~cm}$ of silica in 1:10 ethyl acetate in hexanes), resulting in $404 \mathrm{mg}(71 \%)$ of the $E$-diene 11B. Analytical TLC: $R_{\mathrm{f}}=0.29$ (1:10 ethyl acetate in hexanes). ${ }^{1} \mathrm{H}$ NMR $\left(400 \mathrm{MHz}, \mathrm{CDCl}_{3}, \mathrm{ppm}\right) \delta$ 7.30-7.28 (m, 2H), 7.22-7.17 (m, 3H), $5.99(\mathrm{~d}, 1 \mathrm{H}, \mathrm{J}=16 \mathrm{~Hz}), 5.70(\mathrm{dt}, 1 \mathrm{H}, \mathrm{J}=16$ 
$\mathrm{Hz}, 6.8 \mathrm{~Hz}), 5.48(\mathrm{t}, 1 \mathrm{H}, \mathrm{J}=6.0 \mathrm{~Hz}), 5.07(\mathrm{~d}, 2 \mathrm{H}, \mathrm{J}=5.5 \mathrm{~Hz}), 2.71-2.60(\mathrm{~m}, 2 \mathrm{H})$, $2.09(\mathrm{~s}, 3 \mathrm{H}), 2.09-2.00(\mathrm{~m}, 4 \mathrm{H}), 1.37-1.30(\mathrm{~m}, 4 \mathrm{H}), 0.91(\mathrm{t}, 3 \mathrm{H}, \mathrm{J}=6.8 \mathrm{~Hz}) ;{ }^{13} \mathrm{C}$ NMR $\left(125.7 \mathrm{MHz}, \mathrm{CDCl}_{3}, \mathrm{ppm}\right) \delta 169.8,144.9,141.2,131.6,128.5,128.22$, $128.21,125.8,112.4,73.0,35.6,32.6,31.7,31.2,22.0,20.9,13.7 ; \mathrm{IR}\left(\mathrm{CH}_{2} \mathrm{Cl}_{2}\right.$, $\mathrm{cm}^{-1}$ ) 3026, 2960, 2927, 2861, 1742, 1650, 1604, 1499, 1453, 1367, 1242, 1031, 965, 893, 748, 696; ESI-MS molecular ion calculated for $\mathrm{C}_{19} \mathrm{H}_{26} \mathrm{O}_{2} 286.19$, found $309.18(\mathrm{M}+\mathrm{Na})$, error $2.5 \mathrm{ppm}$.

(4Z,5E)-4-(3-Phenylpropylidene)dec-5-enoic acid (11C, Claisen step, entry 10): To an dry $50 \mathrm{~mL}$ Schlenk tube was introduced $1.5 \mathrm{~mL}$ LHMDS (1.0 M in $\mathrm{THF})$ and $250 \mu \mathrm{L}$ of HMPA and the contents stirred at $-78^{\circ} \mathrm{C}$ for $15 \mathrm{~min}$. In a separate $10 \mathrm{~mL} \mathrm{rb}$ flask was added a solution of $286 \mathrm{mg}(1.0 \mathrm{mmol})$ of diene 11B in $0.7 \mathrm{~mL}$ of THF. To this solution was added $226 \mathrm{mg}(1.5 \mathrm{mmol})$ of TBSCl and allowed to stir for $5 \mathrm{~min}$. The solution of TBSCl and diene 11B were then added dropwise over 10 min. via syringe into the solution of LHMDS and HMPA. The reaction was stirred at $-78^{\circ} \mathrm{C}$ for $1 \mathrm{~h}$ then let warm to room temperature, stirred for a further $23 \mathrm{~h}$. The solution was diluted with $20 \mathrm{~mL}$ of diethyl ether and $2 \mathrm{~mL}$ of brine were added. The ether layer was extracted and washed $2 \times 5 \mathrm{~mL}$ of water. The organic layers were combined, concentrated to a pale yellow oil that was dissolved in $3 \mathrm{~mL}$ THF and $1 \mathrm{~mL}$ of $1.0 \mathrm{M} \mathrm{HCl}$ and stirred at room temperature, for $1 \mathrm{~h}$. The reaction was diluted with $20 \mathrm{~mL}$ of ethyl acetate and washed with $3 \mathrm{~mL}$ sat. $\mathrm{NH}_{4} \mathrm{Cl}$. The organic layers were combined, dried $\left(\mathrm{Na}_{2} \mathrm{SO}_{4}\right)$, filtered, and concentrated in vacuo. The compound was purified by flash column chromatography on silica $(15 \times 2.5 \mathrm{~cm}$ of silica in 1:10 then 1:1 ethyl acetate in hexanes) resulting in $162 \mathrm{mg}(57 \%)$ carboxylic acid 11C. Analytical TLC: $\mathrm{R}_{\mathrm{f}}=0.12{ }^{1} \mathrm{H}$ NMR $\left(500 \mathrm{MHz}, \mathrm{CDCl}_{3}, \mathrm{ppm}\right) \delta 7.26(\mathrm{t}, 2 \mathrm{H}, \mathrm{J}=7.5 \mathrm{~Hz}), 7.20-$ $7.16(\mathrm{~m}, 3 \mathrm{H}), 6.23(\mathrm{~d}, 1 \mathrm{H}, \mathrm{J}=16.0 \mathrm{~Hz}), 5.68(\mathrm{dt}, 1 \mathrm{H}, \mathrm{J}=16.0,7.0 \mathrm{~Hz}), 5.32(\mathrm{t}$, $1 \mathrm{H}, \mathrm{J}=7.5 \mathrm{~Hz}), 2.66(\mathrm{t}, 2 \mathrm{H}, \mathrm{J}=7.5 \mathrm{~Hz}), 2.49-2.42(\mathrm{~m}, 6 \mathrm{H}), 2.10(\mathrm{q}, 2 \mathrm{H}, \mathrm{J}=7.0$ $\mathrm{Hz}), 1.38-1.25(\mathrm{~m}, 4 \mathrm{H}), 0.90(\mathrm{t}, 3 \mathrm{H}, \mathrm{J}=7.0 \mathrm{~Hz}) ;{ }^{13} \mathrm{C} \mathrm{NMR}\left(75.5 \mathrm{MHz}, \mathrm{CDCl}_{3}\right.$, ppm) $\delta 180.1,141.8,134.9,130.9,128.4,128.2,127.6,125.8,125.3,35.9,33.7$, 32.9, 31.6, 29.2, 29.0, 22.2, 13.9; IR $\left(\mathrm{CH}_{2} \mathrm{Cl}_{2}, \mathrm{~cm}^{-1}\right)$ 3026, 2960, 2927, 2861, 1709, 1604, 1499, 1453, 1413, 1307, 1209, 965, 748, 696; ESI-MS molecular ion calculated for $\mathrm{C}_{19} \mathrm{H}_{26} \mathrm{O}_{2} 286.19$, found $309.18(\mathrm{M}+\mathrm{Na})$, error -1.9 ppm. 


\section{Methylene-Free Synthesis of Cyclic Dienes (Table 2)}

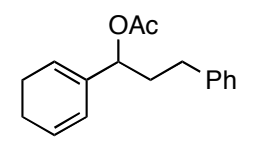

1-(Cyclohexa-1,5-dienyl)-3-phenylpropyl acetate (12B, metathesis step, entry 1): Into an oven-dried $100 \mathrm{~mL}$ Schlenk tube equipped with a stirbar and a cold finger condenser was added all-cis polybutadiene (433 mg, $8 \mathrm{mmol}), 20 \mathrm{~mL}$ $\mathrm{CH}_{2} \mathrm{Cl}_{2}$ followed by Grubbs' second generation catalyst 1 (42 $\mathrm{mg}, 5 \mathrm{~mol} \%$ ). This solution was immersed in an oil bath maintained at $45{ }^{\circ} \mathrm{C}$. The alkyne 5A (202 $\mathrm{mg}, 1 \mathrm{mmol}$ ) was dissolved in ca. $2 \mathrm{~mL}$ of $\mathrm{CH}_{2} \mathrm{Cl}_{2}$ and this solution was added to the solution of all-cis PB and the catalyst in $\mathrm{CH}_{2} \mathrm{Cl}_{2}$ at $45{ }^{\circ} \mathrm{C}$ over a period of $4 \mathrm{~h}$ by means of a gas tight syringe (syringe pump). After the addition was complete, the reaction mixture was stirred at $45^{\circ} \mathrm{C}$ for an additional $30 \mathrm{~min}$. Ethyl vinyl ether (144 mg, $2 \mathrm{mmol}$ ) was the added and the reaction mixture was stirred at $45^{\circ} \mathrm{C}$ for an additional $30 \mathrm{~min}$. The reaction mixture was then concentrated and partially purified by passing a small plug of silica gel $(5.0 \mathrm{~cm})$, eluted with $1 \%$ ethyl acetate in hexanes $(100 \mathrm{~mL})$ to remove the catalyst and the solvent subsequently removed in vacuo (rotary evaporator). The viscous yellow oil thus obtained was further purified by bulb-to-bulb distillation. The distillate $(204 \mathrm{mg})$ was obtained as colorless oil at $97^{\circ} \mathrm{C}(1.7 \mathrm{~mm}$ of $\mathrm{Hg})$. The purification of the distillate using silica gel (elution with $2 \%$ ethyl acetate in hexanes) afforded the cyclohexadiene 12B (164 mg, 64\%) as colorless oil. Analytical tlc: $\mathrm{R}_{f} 0.44(12 \%$ ethyl acetate in hexanes). ${ }^{1} \mathrm{H}-\mathrm{NMR}\left(500 \mathrm{MHz}, \mathrm{CDCl}_{3}, \mathrm{ppm}\right) \delta 7.28-7.25(\mathrm{~m}, 2 \mathrm{H}), 7.18-7.15$ $(\mathrm{m}, 3 \mathrm{H}), 5.96-5.88(\mathrm{~m}, 1 \mathrm{H}), 5.74-5.73(\mathrm{~m}, 1 \mathrm{H}), 5.23(\mathrm{t}, \mathrm{J}=7.0 \mathrm{~Hz}, 1 \mathrm{H}), 2.60-$ $2.56(\mathrm{~m}, 2 \mathrm{H}), 2.19-2.11(\mathrm{~m}, 4 \mathrm{H}), 2.04-1.99(\mathrm{~m}, 4 \mathrm{H}), 1.93-1.87(\mathrm{~m}, 1 \mathrm{H}) ;{ }^{13} \mathrm{C}-$ NMR $\left(125 \mathrm{MHz}, \mathrm{CDCl}_{3}, \mathrm{ppm}\right) \delta 170.3,141.4,134.2,128.3,128.2,127.8,125.8$, 123.6, 122.9, 75.7, 34.8, 31.7, 22.1, 21.9, 21.2; FT-IR (thin film, $\mathrm{cm}^{-1}$ ) 2933, $1738,1370,1238,1020$; High-resolution $\mathrm{MS}\left(\mathrm{El}^{+}, \mathrm{m} / \mathrm{z}\right)$ molecular ion calcd for $\mathrm{C}_{17} \mathrm{H}_{20} \mathrm{O}_{2} 256.1458$, found 279.1350, [M+Na] $]^{+}$, error $1.9 \mathrm{ppm}$.

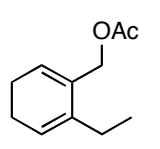

(6-Ethylcyclohexa-1,5-dienyl)methyl acetate (13B, metathesis step, entry 2): Into an oven-dried $50 \mathrm{~mL}$ Schlenk tube equipped with a magnetic stirbar and a cold finger condenser, was added 1,5-COD (1.1 mL, $9.0 \mathrm{mmol}, 9.0$ equiv) followed by $20 \mathrm{~mL} \mathrm{CH} \mathrm{Cl}_{2}$. This solution was purged with $\mathrm{Ar}$ for ca. $5 \mathrm{~min}$. Subsequently, Grubbs' second generation catalyst ( $42 \mathrm{mg}, 5 \mathrm{~mol} \%$ ) was added to this solution and the schlenk tube was immersed into an oil bath maintained at $45^{\circ} \mathrm{C}$. The alkyne (126 mg, $1.0 \mathrm{mmol}, 1.0$ equiv) was dissolved in $2.0 \mathrm{~mL} \mathrm{CH} \mathrm{Cl}_{2}$ and this was taken up in a $5.0 \mathrm{~mL}$ gas tight syringe. This solution of the alkyne was added to the contents of the schlenk tube over $4 \mathrm{~h}$ (syringe pump). After the addition was complete, the reaction mixture was stirred at $45^{\circ} \mathrm{C}$ for an additional 
$45 \mathrm{~min}$. The reaction mixture was concentrated to afford a dark brown viscous oil. To this was added ice-cold methanol $(10 \mathrm{~mL})$ and the heterogeneous mixture was stirred at $0{ }^{\circ} \mathrm{C}$ for $\mathrm{ca}$. $10 \mathrm{~min}$. The methanol was collected by decantation and the extraction was repeated two more times. The methanol extracts were combined and the solvent removed in vacuo (rotary evaporator). The brown oil thus obtained was further purified by means of flash column chromatography using silica gel. Elution with $1 \%$ ethyl acetate in hexanes afforded the cyclohexadiene derivative 13B (130 mg, 72\% yield) as pale yellow oil. Analytical tlc: $R_{f}=0.34$ (10\% ethyl acetate in hexanes). ${ }^{1} \mathrm{H}-\mathrm{NMR}\left(500 \mathrm{MHz}, \mathrm{CDCl}_{3}, \mathrm{ppm}\right)$,

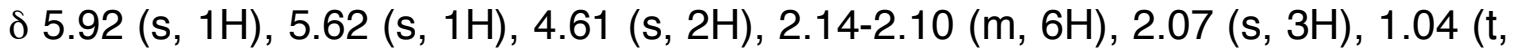
$\mathrm{J}=7.5 \mathrm{~Hz}, 3 \mathrm{H}) ;{ }^{13} \mathrm{C}-\mathrm{NMR}\left(125 \mathrm{MHz}, \mathrm{CDCl}_{3}, \mathrm{ppm}\right) \delta 170.9,137.0,132.6,128.2$, 121.2, 65.4, 24.6, 22.5, 22.1, 21.1, 12.9; FT-IR (thin film, $\mathrm{cm}^{-1}$ ) 2935, 1741, 1376, $1228,1023,964,829$; High-resolution $\mathrm{MS}\left(\mathrm{El}^{+}, \mathrm{m} / \mathrm{z}\right)$ molecular ion calcd for $\mathrm{C}_{11} \mathrm{H}_{16} \mathrm{O}_{2} 180.1145$, found 180.1144 , error $0.7 \mathrm{ppm}$.

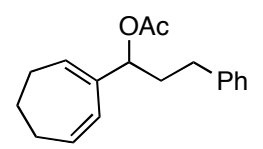

1-[(1E,6Z)-Cyclohepta-1,6-dienyl]-3-phenylpropyl acetate (15B, metathesis step, entry 4): Into an oven-dried Schlenk tube (100 mL) equipped with magnetic stirbar and a cold finger condenser was added $\mathrm{CH}_{2} \mathrm{Cl}_{2}(50 \mathrm{~mL})$ followed by Grubbs' second generation catalyst $(42.4 \mathrm{mg}, 5 \mathrm{~mol} \%)$ and the solution was immersed into an oil bath maintained at $45{ }^{\circ} \mathrm{C}$. Alkyne 5A (202 mg, $\left.1.0 \mathrm{mmol}\right)$ and cyclopentene (272 mg, $4.0 \mathrm{mmol}$ ) were dissolved in ca. $2.0 \mathrm{~mL} \mathrm{CH}_{2} \mathrm{Cl}_{2}$ and this solution was then added to the solution of the catalyst in $\mathrm{CH}_{2} \mathrm{Cl}_{2}$ at $45^{\circ} \mathrm{C}$ over a period of $16 \mathrm{~h}$ by means of a gas tight syringe (syringe pump). After the reaction was complete, the reaction mixture was stirred at $45^{\circ} \mathrm{C}$ for additional 45 min. Ethyl vinyl ether ( $144 \mathrm{mg}, 2 \mathrm{mmol}$ ) was then added and the reaction mixture was stirred at $45{ }^{\circ} \mathrm{C}$ for additional $30 \mathrm{~min}$. The reaction mixture was then concentrated in vacuo (rotary evaporator) to afford a viscous brown oil. The latter was purified by flash column chromatography using silica gel. Elution with $2 \%$ ethyl acetate in hexanes afforded the cycloheptadiene 15B (176 mg, 65\% yield) as pale yellow oil. Analytical tlc: $\mathrm{R}_{f}=0.38\left(10 \%\right.$ ethyl acetate in hexanes). ${ }^{1} \mathrm{H}$ NMR $\left(500 \mathrm{MHz}, \mathrm{CDCl}_{3}, \mathrm{ppm}\right), \delta 7.28-7.25(\mathrm{~m}, 2 \mathrm{H}), 7.17(\mathrm{t}, \mathrm{J}=7.5 \mathrm{~Hz}, 3 \mathrm{H})$, 5.95 (dt, J = 12.0, $5.0 \mathrm{~Hz}, 1 \mathrm{H}$ ), $5.89(\mathrm{t}, \mathrm{J}=5.0 \mathrm{~Hz}, 1 \mathrm{H}), 5.82(\mathrm{~d}, \mathrm{~J}=12.0 \mathrm{~Hz}, 1 \mathrm{H}$ ), $5.16(\mathrm{t}, \mathrm{J}=7.0 \mathrm{~Hz}, 1 \mathrm{H}), 2.63-2.56(\mathrm{~m}, 2 \mathrm{H}), 2.31-2.27(\mathrm{~m}, 4 \mathrm{H}), 2.07-2.00(\mathrm{~m}$, $4 \mathrm{H}), 1.93-1.81(\mathrm{~m}, 3 \mathrm{H}) ;{ }^{13} \mathrm{C}-\mathrm{NMR}\left(125 \mathrm{MHz}, \mathrm{CDCl}_{3}, \mathrm{ppm}\right) \delta 170.1,141.4$, 134.98, 134.95, 132.0, 128.25, 128.22, 125.8, 123.9, 78.6, 35.4, 31.8, 31.4, 29.8, 26.8, 21.2; FT-IR (thin film, $\mathrm{cm}^{-1}$ ) 2933, 1742, 1367, 1249, 1031; High-resolution MS $\left(\mathrm{El}^{+}, \mathrm{m} / \mathrm{z}\right)$ molecular ion calcd for $\mathrm{C}_{18} \mathrm{H}_{22} \mathrm{O}_{2} 270.1614$, found 270.1617 , error $0.9 \mathrm{ppm}$. 
General procedure for the Claisen rearrangement of the cyclodienes to the corresponding carboxylic acids (Table 2)

An oven-dried Schlenk tube ( $50 \mathrm{~mL}$ ) equipped with a magnetic stirbar was charged with $0.75 \mathrm{~mL}$ of $1.0 \mathrm{M}$ LiHMDS in THF ( $0.75 \mathrm{M}, 1.5$ equiv). This was cooled to $-78{ }^{\circ} \mathrm{C}$ (dry ice-acetone bath) for 15 minutes. $125 \mu \mathrm{L} \mathrm{HMPA}$ was added to this solution maintained at $-78{ }^{\circ} \mathrm{C}$. In a separate round bottom flask $(10 \mathrm{~mL})$ was dissolved a mixture of cyclodiene $(0.5 \mathrm{mmol}, 1.0$ equiv) and TBSCl (0.75 mmol, 1.5 equiv) in $0.5 \mathrm{~mL}$ THF. This solution was added dropwise with gas tight syringe into LiHMDS-HMPA solution maintained at $-78{ }^{\circ} \mathrm{C}$ over $3-4$ minutes. The flask was rinsed with additional $300 \mu \mathrm{L}$ THF and this solution was added to the solution of the base and HMPA. The reaction mixture was stirred at $-78{ }^{\circ} \mathrm{C}$ for 20 min and then slowly warmed to RT. It was stirred at RT for $24 \mathrm{~h}$. The reaction was quenched by addition of $5 \mathrm{~mL}$ of saturated $\mathrm{NH}_{4} \mathrm{Cl}$ solution. The reaction mixture was poured into a separatory funnel containing $20 \mathrm{~mL}$ of diethyl ether and $20 \mathrm{~mL}$ of saturated $\mathrm{NH}_{4} \mathrm{Cl}$ solution. The organic layer was washed with distilled water $(2 \mathrm{X} 20 \mathrm{~mL})$ and finally with saturated $\mathrm{NH}_{4} \mathrm{Cl}$ solution. The organic layer was separated, dried over anhydrous $\mathrm{Na}_{2} \mathrm{SO}_{4}$ and the diethyl ether was removed in vacuo (rotary evaporator). The pale brown oil thus obtained was redissolved in $5 \mathrm{~mL}$ THF and $0.5 \mathrm{~mL}$ of $1.0 \mathrm{M} \mathrm{HCl}$ was added to it. This was stirred at RT for $45 \mathrm{~min}$. The reaction was quenched by pouring the reaction mixture into a separatory funnel containing $20 \mathrm{~mL}$ distilled water and $20 \mathrm{~mL}$ diethyl ether. The organic layer was washed with distilled water $(2 X 20 \mathrm{~mL})$ and finally with saturated $\mathrm{NH}_{4} \mathrm{Cl}$ solution $(20 \mathrm{~mL})$. It was dried using anhydrous $\mathrm{Na}_{2} \mathrm{SO}_{4}$ and the solvent removed in vacuo (rotary evaporator). The yellow oil thus obtained was purified by using silica gel flash column chromatography. Gradient elution with $10 \%$ ethyl acetate in hexanes $(100 \mathrm{~mL})$ followed by $20 \%$ ethyl acetate in hexanes $(100 \mathrm{~mL})$ afforded the desired carboxylic acid as pale yellow oil.

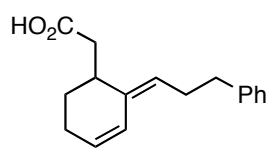

(Z)-2-[2-(3-Phenylpropylidene)cyclohex-3-enyl)acetic acid (12C, entry 1): As the general experimental. The carboxylic acid $12 \mathrm{C}$ was obtained as pale yellow oil $\left(87 \mathrm{mg}, 68 \%\right.$ yield). Analytical tlc: $0.30\left(50 \%\right.$ ethyl acetate in hexanes). ${ }^{1} \mathrm{H}$ NMR $\left(500 \mathrm{MHz}, \mathrm{CDCl}_{3}, \mathrm{ppm}\right) \delta 7.27-7.24(\mathrm{~m}, 2 \mathrm{H}), 7.18-7.15(\mathrm{~m}, 3 \mathrm{H}), 6.29(\mathrm{~d}$, $\mathrm{J}=10.0 \mathrm{~Hz}, 1 \mathrm{H}), 5.76-5.74(\mathrm{~m}, 1 \mathrm{H}), 5.27(\mathrm{t}, \mathrm{J}=7.5 \mathrm{~Hz}, 1 \mathrm{H}), 2.81-2.79(\mathrm{~m}$, $1 \mathrm{H}), 2.64(\mathrm{t}, \mathrm{J}=7.5 \mathrm{~Hz}, 2 \mathrm{H}), 2.46-2.36(\mathrm{~m}, 4 \mathrm{H}), 2.18-2.09(\mathrm{~m}, 2 \mathrm{H}), 1.79-$ $1.74(\mathrm{~m}, 1 \mathrm{H}), 1.72-1.67(\mathrm{~m}, 1 \mathrm{H}) ;{ }^{13} \mathrm{C}-\mathrm{NMR}\left(125 \mathrm{MHz}, \mathrm{CDCl}_{3}, \mathrm{ppm}\right) \delta$ 179.6, 141.8, 135.7, 128.6, 128.4, 128.2, 125.8, 125.4, 122.9, 38.3, 37.0, 36.0, 28.8, 26.9, 22.4; FT-IR (thin film, $\mathrm{cm}^{-1}$ ) 2933, 1716, 1460, 1295, 939; High-resolution MS $\left(\mathrm{El}^{+}, \mathrm{m} / \mathrm{z}\right)$ molecular ion calcd for $\mathrm{C}_{17} \mathrm{H}_{20} \mathrm{O}_{2} 256.1458$, found 256.1456, error $0.8 \mathrm{ppm}$. 


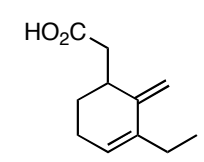

2-(3-Ethyl-2-methylenecyclohex-3-enyl)acetic acid (13C, entry 2): As the general experimental. The carboxylic acid $13 \mathrm{C}$ was obtained as a pale yellow oil (55 mg, 61\% yield). Analytical tlc: 0.28 (50\% ethyl acetate in hexanes). ${ }^{1} \mathrm{H}-\mathrm{NMR}$ $\left(500 \mathrm{MHz}, \mathrm{CDCl}_{3}, \mathrm{ppm}\right) \delta 5.63(\mathrm{~s}, 1 \mathrm{H}), 4.98(\mathrm{~s}, 1 \mathrm{H}), 4.87(\mathrm{~s}, 1 \mathrm{H}), 2.93-2.88(\mathrm{~m}$, $1 \mathrm{H}), 2.50$ (dd, J = 15.0, 7.5 Hz, 1H) 2.41 (dd, $J=15.0,7.5 \mathrm{~Hz}, 1 \mathrm{H}), 2.24-2.14(\mathrm{~m}$, 4H), 1.83-1.77 (m, 1H), 1.71-1.66 (m, 1H), $1.04(\mathrm{t}, \mathrm{J}=7.5 \mathrm{~Hz}, 3 \mathrm{H}) ;{ }^{13} \mathrm{C}-\mathrm{NMR}(125$ $\left.\mathrm{MHz}, \mathrm{CDCl}_{3}, \mathrm{ppm}\right) \delta 179.6,145.4,137.0,124.7,108.2,38.2,37.5,27.2,25.7$, 22.8, 13.1; FT-IR (thin film, $\mathrm{cm}^{-1}$ ) 2929, 1708, 1604, 1292, 1202, 888; Highresolution $\mathrm{MS}\left(\mathrm{El}^{+}, \mathrm{m} / \mathrm{z}\right)$ molecular ion calcd for $\mathrm{C}_{11} \mathrm{H}_{16} \mathrm{O}_{2} 180.1145$, found 180.1142, error $1.7 \mathrm{ppm}$.

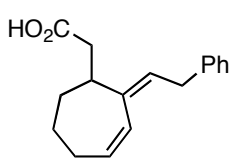

2-[(2Z, 3Z)-2-(2-Phenylethylidene)cyclohept-3-enyl]acetic acid (14C, entry $3)$ : As the general experimental. The carboxylic acid 14C was obtained as pale yellow oil ( $81 \mathrm{mg}, 63 \%$ yield). Analytical tlc: 0.28 (50\% ethyl acetate in hexanes). ${ }^{1} \mathrm{H}-\mathrm{NMR}\left(500 \mathrm{MHz}, \mathrm{CDCl}_{3}\right.$, ppm) $\delta$ 7.27-7.24 (m, 2H), $7.18-7.15(\mathrm{~m}, 3 \mathrm{H}), 6.32$ (dd, J = 12.0, 1.0 Hz, 1H), $5.84(\mathrm{dt}, \mathrm{J}=12.0,5.0 \mathrm{~Hz}, 1 \mathrm{H}), 5.47(\mathrm{t}, \mathrm{J}=7.5 \mathrm{~Hz}, 1 \mathrm{H})$, $3.41(\mathrm{~d}, \mathrm{~J}=7.5 \mathrm{~Hz}, 2 \mathrm{H}), 3.05-2.99(\mathrm{~m}, 1 \mathrm{H}), 2.60(\mathrm{dd}, \mathrm{J}=15.0,8.0 \mathrm{~Hz}, 1 \mathrm{H}), 2.47$ $(\mathrm{dd}, \mathrm{J}=15.0,8.0 \mathrm{~Hz}, 1 \mathrm{H}), 2.26-2.23(\mathrm{~m}, 2 \mathrm{H}), 1.93-1.85(\mathrm{~m}, 1 \mathrm{H}), 1.77-1.64$ $(\mathrm{m}, 2 \mathrm{H}), 1.56-1.50(\mathrm{~m}, 1 \mathrm{H}) ;{ }^{13} \mathrm{C}-\mathrm{NMR}\left(125 \mathrm{MHz}, \mathrm{CDCl}_{3}, \mathrm{ppm}\right) \delta$ 179.7, 140.9, 139.7, 132.9, 128.34, 128.30, 127.8, 125.8, 125.5, 41.6, 39.3, 34.8, 34.2, 29.5, 24.1; FT-IR (thin film, $\mathrm{cm}^{-1}$ ) 2933, 1716, 1470, 1301, 939; High-resolution MS $\left(\mathrm{El}^{+}, \mathrm{m} / \mathrm{z}\right)$ molecular ion calcd for $\mathrm{C}_{17} \mathrm{H}_{20} \mathrm{O}_{2} 256.1458$, found 256.1454 , error 1.5 ppm.

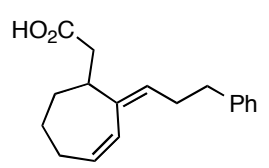

2-[(2Z, 3Z)-2-(3-phenylpropylidene)cyclohept-3-enyl]acetic acid (15C, entry 4): As the general experimental. The carboxylic acid 15C was obtained as pale yellow oil (91 mg, 68\% yield). Analytical tlc: $R_{f} 0.28(50 \%$ ethyl acetate in hexanes). ${ }^{1} \mathrm{H}-\mathrm{NMR}\left(500 \mathrm{MHz}, \mathrm{CDCl}_{3}, \mathrm{ppm}\right) \delta 7.17-7.14(\mathrm{~m}, 2 \mathrm{H}), 7.07-7.04(\mathrm{~m}$, $3 \mathrm{H}), 6.02(\mathrm{dd}, \mathrm{J}=12,1.0 \mathrm{~Hz}, 1 \mathrm{H}), 5.63(\mathrm{dt}, \mathrm{J}=12.0,5.0 \mathrm{~Hz}, 1 \mathrm{H}), 5.2(\mathrm{t}, \mathrm{J}=7.5$ $\mathrm{Hz}, 1 \mathrm{H}), 2.86-2.80(\mathrm{~m}, 1 \mathrm{H}), 2.54(\mathrm{t}, \mathrm{J}=7.5 \mathrm{~Hz}, 2 \mathrm{H}), 2.43(\mathrm{dd}, \mathrm{J}=15.0,8.0 \mathrm{~Hz}$, $1 \mathrm{H}), 2.32(\mathrm{dd}, \mathrm{J}=15.0,8.0 \mathrm{~Hz}, 1 \mathrm{H}), 2.27-2.23(\mathrm{~m}, 2 \mathrm{H}), 2.07(\mathrm{dd}, \mathrm{J}=10.0,5.0$ 
$\mathrm{Hz}, 2 \mathrm{H}), 1.76-1.70(\mathrm{~m}, 1 \mathrm{H}), 1.57-1.52(\mathrm{~m}, 1 \mathrm{H}), 1.50-1.42(\mathrm{~m}, 1 \mathrm{H}), 1.40-$ $1.34(\mathrm{~m}, 1 \mathrm{H}) ;{ }^{13} \mathrm{C}-\mathrm{NMR}\left(125 \mathrm{MHz}, \mathrm{CDCl}_{3}, \mathrm{ppm}\right) \delta 178.8,141.9,139.3,132.1$, 128.4, 128.2, 127.8, 126.3, 125.7, 41.6, 39.2, 35.7, 34.8, 29.9, 29.4, 24.0; FT-IR (thin film, $\left.\mathrm{cm}^{-1}\right)$ 2940, 1709, 1503, 1459, 1295, 709; High-resolution $\mathrm{MS}\left(\mathrm{El}^{+}, \mathrm{m} / \mathrm{z}\right)$ molecular ion calcd for $\mathrm{C}_{18} \mathrm{H}_{22} \mathrm{O}_{2} 270.1614$, found 270.1612, error 1.0 ppm.

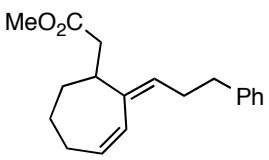

Methyl 2-[(2Z, 3Z)-2-(3-phenylpropylidene)cyclohept-3-enyl]acetate (16C): An oven-dried Schlenk tube $(50 \mathrm{~mL})$ equipped with a magnetic stirbar was charged with $0.75 \mathrm{~mL}$ of $1.0 \mathrm{M}$ LiHMDS in THF ( $0.75 \mathrm{M}, 1.5$ equiv). This was cooled to $-78{ }^{\circ} \mathrm{C}$ (dry ice-acetone bath) for 15 minutes. $125 \mu \mathrm{L} \mathrm{HMPA}$ was added to this solution maintained at $-78{ }^{\circ} \mathrm{C}$. In a separate round bottom flask $(10 \mathrm{~mL})$ was dissolved a mixture of cyclodiene 15B $(0.5 \mathrm{mmol}, 1.0$ equiv.) and TBSCl ( $0.75 \mathrm{mmol}, 1.5$ equiv) in $0.5 \mathrm{~mL}$ THF. This solution was added dropwise with gas tight syringe into LiHMDS-HMPA solution maintained at $-78{ }^{\circ} \mathrm{C}$ over $3-4$ minutes. The flask was rinsed with additional $300 \mu \mathrm{L}$ THF and this solution was added to the solution of the base and HMPA. The reaction mixture was stirred at $-78{ }^{\circ} \mathrm{C}$ for 20 min and then slowly warmed to RT. It was stirred at RT for $24 \mathrm{~h}$. The reaction mixture was concentrated at this stage to afford a pale brown oil. To this was added HMPA (1 mL), $\mathrm{KHCO}_{3}$ (100 mg, 2.0 equiv), KF (94.2 mg. 2.0 equiv) and Mel (156 mL, 5.0 equiv) and this reaction mixture was stirred at RT for $15 \mathrm{~h}$. The reaction was quenched by pouring the reaction mixture into a separatory funnel containing $20 \mathrm{~mL}$ distilled water and $20 \mathrm{~mL}$ diethyl ether. The organic layer was washed with distilled water $(2 X 20 \mathrm{~mL})$ and finally with saturated $\mathrm{NaCl}$ solution $(20 \mathrm{~mL})$. It was dried using anhydrous $\mathrm{Na}_{2} \mathrm{SO}_{4}$ and the solvent removed in vacuo (rotary evaporator). The yellow oil thus obtained was purified by using silica gel flash column chromatography. Elution with $2 \%$ ethyl acetate in hexanes afforded the desired ester $16 \mathrm{C}$ (90 $\mathrm{mg}, 63 \%$ yield) as pale yellow oil. Analytical tlc: 0.34 (10\% ethyl acetate in hexanes). ${ }^{1} \mathrm{H}$ - NMR (500 $\left.\mathrm{MHz}, \mathrm{CDCl}_{3}, \mathrm{ppm}\right) \delta 7.27-7.24(\mathrm{~m}, 2 \mathrm{H}), 7.17-7.14(\mathrm{~m}, 3 \mathrm{H}), 6.14(\mathrm{dd}, \mathrm{J}=12.0$, $1.0 \mathrm{~Hz}, 1 \mathrm{H}), 5.73(\mathrm{dt}, \mathrm{J}=12.0,5.0 \mathrm{~Hz}, 1 \mathrm{H}), 5.29(\mathrm{t}, \mathrm{J}=7.0 \mathrm{~Hz}, 1 \mathrm{H}), 3.62(\mathrm{~s}, 3 \mathrm{H})$, $2.97-2.91(\mathrm{~m}, 1 \mathrm{H}), 2.64(\mathrm{t}, \mathrm{J}=7.0 \mathrm{~Hz}, 2 \mathrm{H}), 2.50(\mathrm{dd}, \mathrm{J}=15.0,8.0 \mathrm{~Hz}, 1 \mathrm{H}), 2.41$ $-2.33(\mathrm{~m}, 3 \mathrm{H}), 2.19-2.15(\mathrm{~m}, 2 \mathrm{H}), 1.84-1.77(\mathrm{~m}, 1 \mathrm{H}), 1.68-1.53(\mathrm{~m}, 2 \mathrm{H})$, $1.49-1.43(\mathrm{~m}, 1 \mathrm{H}) ;{ }^{13} \mathrm{C}-\mathrm{NMR}\left(125 \mathrm{MHz}, \mathrm{CDCl}_{3}, \mathrm{ppm}\right) \delta 173.2,141.9,139.5$, 131.9, 128.4, 128.2, 127.7, 126.2, 125.7, 51.3, 41.9, 39.3, 35.7, 34.7, 29.8, 29.5, 23.9; FT-IR (thin film, $\mathrm{cm}^{-1}$ ) 2920, 1749, 1433, 1249, 1143; High-resolution MS $\left(\mathrm{El}^{+}, \mathrm{m} / \mathrm{z}\right)$ molecular ion calcd for $\mathrm{C}_{19} \mathrm{H}_{24} \mathrm{O}_{2} 284.1771$, found 284.1776 , error 1.7 $\mathrm{ppm}$. When the vinylic triplet at $\delta 5.29 \mathrm{ppm}$ was irradiated, nOe enhancement was seen for the protons at $\delta 2.97-2.91 \mathrm{ppm}, 2.64 \mathrm{ppm}$ (allylic protons) and 2.50 ppm. 


\section{Mode Selective Ene Reaction / Cycloaddition Reaction}

Compound 12D: The carboxylic acid 12C (51 mg, $0.2 \mathrm{mmole}$ ) was dissolved in a mixture of $1.0 \mathrm{~mL} \mathrm{CH} \mathrm{Cl}_{2}$ and $0.6 \mathrm{~mL}$ of $\mathrm{CH}_{3} \mathrm{OH}$. This solution was cooled to 0 ${ }^{\circ} \mathrm{C}$ using an ice bath for $15 \mathrm{~min}$. To this solution was added $\mathrm{TMSCHN}_{2}(120 \mu \mathrm{L}$, 1.2 equiv) (2.0 M solution in ether). The reaction mixture was stirred at $0{ }^{\circ} \mathrm{C}$ for $20 \mathrm{~min}$ and then slowly brought to RT. The reaction mixture was concentrated and purified using silica gel flash column chromatography $(1 \times 10 \mathrm{~cm})$. Elution with $2 \%$ ethyl acetate in hexanes afforded the desired methyl ester 12D (49 mg, $91 \%$ yield) as colorless oil. Analytical tlc: 0.31 (10\% ethyl acetate in hexanes). ${ }^{1} \mathrm{H}-\mathrm{NMR}\left(500 \mathrm{MHz}, \mathrm{CDCl}_{3}, \mathrm{ppm}\right)$ 8 7.29-7.26 (m, 2H), 7.18-7.16 (m, 3H), 6.30 (d, $\mathrm{J}=10.0 \mathrm{~Hz}, 1 \mathrm{H}), 5.77-5.75(\mathrm{~m}, 1 \mathrm{H}), 5.23(\mathrm{t}, \mathrm{J}=7.5 \mathrm{~Hz}, 1 \mathrm{H}), 3.64(\mathrm{~s}, 3 \mathrm{H}), 2.82-$ $2.79(\mathrm{~m}, 1 \mathrm{H}), 2.68-2.63(\mathrm{~m}, 2 \mathrm{H}), 2.44-2.32(\mathrm{~m}, 4 \mathrm{H}), 2.17-2.13(\mathrm{~m}, 2 \mathrm{H}), 1.78-1.72$ $(\mathrm{m}, 1 \mathrm{H}), 1.67-1.63(\mathrm{~m}, 1 \mathrm{H}) ;{ }^{13} \mathrm{C}-\mathrm{NMR}\left(125 \mathrm{MHz}, \mathrm{CDCl}_{3}, \mathrm{ppm}\right) \delta$ 173.4, 141.2, $135.9,128.6,128.4,128.2,125.8,125.2,122.9,51.4$, 38.3, 37.3, 36.0, 28.8, 27.0, 22.5; FT-IR (thin film, $\mathrm{cm}^{-1}$ ) 3028, 2925, 1738, 1435, 1274, 1156, 1019; High-resolution $\mathrm{MS}\left(\mathrm{El}^{+}, \mathrm{m} / \mathrm{z}\right)$ molecular ion calcd for $\mathrm{C}_{18} \mathrm{H}_{22} \mathrm{O}_{2} \mathrm{Na}_{1}$ 293.1517, found 293.1519, error $0.7 \mathrm{ppm}$.<smiles>COCCC12C=C([C@H](CCc3ccccc3)N(O)C(=O)OCc3ccccc3)C(CC1)ON(C(=O)OC(C)(C)C)C2=O</smiles>

Tandem Cycloadduct 18: An oven-dried, argon-cooled schlenk tube equipped with a stir bar and a cold finger condenser was charged with a solution of the $s$ trans diene 12D (27.0 mg, $0.1 \mathrm{mmole}$ ) and $\mathrm{BocNHOH}(61.5 \mathrm{mg}, 0.5 \mathrm{mmole}, 5.0$ equiv) in $2 \mathrm{~mL} \mathrm{CH}_{2} \mathrm{Cl}_{2}$. This solution was cooled in an ice bath for ca. $15 \mathrm{~min}$. A solution of $\mathrm{Pr}_{4} \mathrm{NIO}_{4}$ (207 mg, 0.55 mmoles, 5.5 equiv) dissolved in $2.0 \mathrm{~mL} \mathrm{CH} \mathrm{Cl}_{2}$ was taken up into a gas tight syringe (5.0 mL capacity). The solution of the oxidant was added to the solution of the diene and the hydroxamic acid maintained at $0{ }^{\circ} \mathrm{C}$, over a period of $2 \mathrm{~h}$. Analysis of the reaction mixture after $\mathrm{t}=$ $2 \mathrm{~h}$ (tlc) revealed complete consumption of the diene. The reaction mixture was concentrated in vacuo (rotary evaporator) and purified by using silica gel flash column chromatography ( $1 \times 10 \mathrm{~cm})$. Gradient elution with $10 \%$ ethyl acetate in hexanes followed by $20 \%$ ethyl acetate in hexanes afforded the major diastereomer ( $26 \mathrm{mg}, 48 \%$ yield) and the minor diastereomer (15 mg, 28\% yield) both as pale yellow oils.

Characterization of the major diastereomer: Analytical tlc: 0.23 (25\% ethyl acetate in hexanes). ${ }^{1} \mathrm{H}$ - NMR $\left(500 \mathrm{MHz}, \mathrm{CDCl}_{3}, \mathrm{ppm}\right) \delta$ 7.30-7.26 (m, 2H), 7.22$7.17(\mathrm{~m}, 3 \mathrm{H}), 6.48(\mathrm{~d}, \mathrm{~J}=6.0 \mathrm{~Hz}, 1 \mathrm{H}), 5.99(\mathrm{~s}, 1 \mathrm{H}), 5.13(\mathrm{br} \mathrm{s}, 1 \mathrm{H}), 4.74-4.72(\mathrm{~m}$, 2H), $3.72(\mathrm{~s}, 3 \mathrm{H}), 3.32(\mathrm{~d}, \mathrm{~J}=17.0 \mathrm{~Hz}, 1 \mathrm{H}), 2.80(\mathrm{~d}, \mathrm{~J}=17.0 \mathrm{~Hz}, 1 \mathrm{H}), 2.66-2.56$ 
(m, 2H), 2.23-2.2.16 (m, 1H), 2.14-2.08 (m, 1H), 1.99-1.92 (m, 2H), 1.84-1.78 (m. $1 \mathrm{H}), 1.59-1.53(\mathrm{~m}, 1 \mathrm{H}), 1.48(\mathrm{~s}, 9 \mathrm{H}), 1.44(\mathrm{~s}, 9 \mathrm{H}) ;{ }^{13} \mathrm{C}-\mathrm{NMR}\left(125 \mathrm{MHz}, \mathrm{CDCl}_{3}\right.$, ppm) $\delta 170.6,161.8,155.9,141.8,140.7,128.8,128.39,128.35,125.9,83.2$, 81.5, 78.9, 53.9, 51.8, 37.5, 32.3, 28.8, 29.8, 28.2, 28.0, 20.0; FT-IR (thin film, $\left.\mathrm{cm}^{-1}\right) 3380,2935,1737,1393,1162,1093,913$; High-resolution $\mathrm{MS}\left(\mathrm{El}^{+}, \mathrm{m} / \mathrm{z}\right)$ molecular ion calcd for $\mathrm{C}_{28} \mathrm{H}_{40} \mathrm{~N}_{2} \mathrm{O}_{8} \mathrm{Na}_{1} 555.2682$, found 555.2667, error $2.7 \mathrm{ppm}$. NOE data: Irradiation of the multiplet at $\delta=4.74-4.72$ (exocyclic allylic methine proton) resulted in the enhancement of the proton signals at $\delta=6.48(3.5 \%)$ and 2.14-2.08 $(2.17 \%$ ). Irradiation of the proton at $\delta=3.32$ (downfield proton of the $A B$ quartet) resulted in the enhancement of the proton signals at $\delta=5.99(0.35$ $\%), 5.13(1.7 \%)$ and $2.80(17.6 \%)$. Irradiation of the proton at $\delta=2.80$ (upfield proton of the $A B$ quartet) resulted in the enhancement of the proton signals at $\delta=$ $5.99(0.97 \%), 5.13(1.5 \%)$ and $3.32(15.6 \%)$. In addition, irradiation of the methine proton at $\delta$ 4.74-4.72 ppm gave nOe enhancement with the methyl protons of the tert-butyl group appearing at $\delta 1.44 \mathrm{ppm}$ (upfield Boc group).

Characterization of the minor diastereomer: Analytical tlc: 0.09 (25\% ethyl acetate in hexanes). ${ }^{1} \mathrm{H}$ - NMR $\left(500 \mathrm{MHz}, \mathrm{CDCl}_{3}, \mathrm{ppm}\right) \delta$ 7.31-7.28 (m, 2H), 7.21$7.19(\mathrm{~m}, 3 \mathrm{H}), 6.62(\mathrm{~d}, \mathrm{~J}=6.0 \mathrm{~Hz}, 1 \mathrm{H}), 6.45(\mathrm{br} \mathrm{s}, 1 \mathrm{H}), 4.97(\mathrm{t}, \mathrm{J}=6.0 \mathrm{~Hz}, 1 \mathrm{H})$, 4.77-4.75 (m, 1H), $3.68(\mathrm{~s}, 3 \mathrm{H}), 3.08(\mathrm{~d}, \mathrm{~J}=15.5 \mathrm{~Hz}, 1 \mathrm{H}), 2.82(\mathrm{~d}, \mathrm{~J}=15.5 \mathrm{~Hz}$, $1 \mathrm{H}), 2.67-2.56(\mathrm{~m}, 2 \mathrm{H}), 2.19-2.06(\mathrm{~m}, 4 \mathrm{H}), 1.57-1.53(\mathrm{~m}, 2 \mathrm{H}), 1.43(\mathrm{~s}, 9 \mathrm{H}), 1.42$ (s, 9H); ${ }^{13} \mathrm{C}-\mathrm{NMR}\left(125 \mathrm{MHz}, \mathrm{CDCl}_{3}, \mathrm{ppm}\right) \delta 169.9,158.1,156.5,141.7,141.3$, 129.2, 128.43, 128.39, 126.0, 82.7, 81.6, 78.5, 56.5, 51.8, 50.5, 38.2, 32.3, 31.1, 29.7, 28.2, 28.1, 21.2; FT-IR (thin film, $\mathrm{cm}^{-1}$ ) 3254, 2976, 1742, 1685, 1368, 1167; High-resolution $\mathrm{MS}\left(\mathrm{El}^{+}, \mathrm{m} / \mathrm{z}\right)$ molecular ion calcd for $\mathrm{C}_{28} \mathrm{H}_{40} \mathrm{~N}_{2} \mathrm{O}_{8} \mathrm{Na}_{1}$ 555.2682 , found 555.2682, error $0.0 \mathrm{ppm}$. NOe data: Irradiation of the multiplet at $\delta=4.77-4.75$ resulted in the enhancement of the proton signal at $\delta=6.62(2.2$ $\%)$. Irradiation of the proton at $\delta=3.08$ (downfield proton of the $A B$ quartet) resulted in the enhancement of the proton signals at $\delta=4.97(2.40 \%)$ and 2.82 (14.2\%). Irradiation of the proton at $\delta=2.82$ (upfield proton of the $A B$ quartet) resulted in the enhancement of the proton signals at $\delta=4.97(0.89 \%)$ and 3.08 (15.8\%). 


\section{Chirality Transfer}

Scheme S2. Preparation of Enantiomerically-Enriched Propionate 20

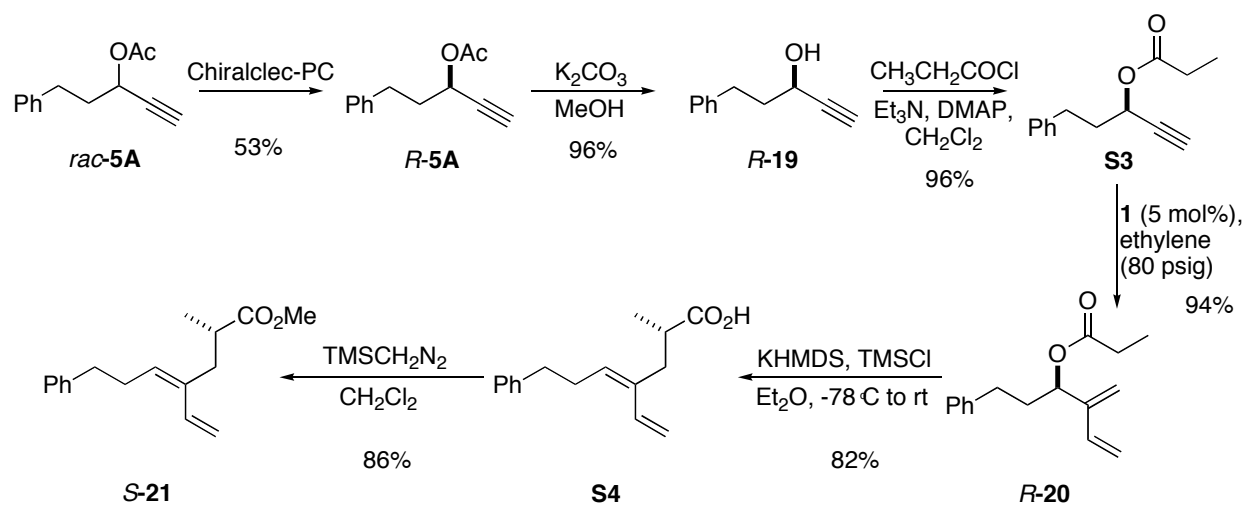

(R)-5-Phenylpent-1-yn-3-yl acetate $(R-5 \mathrm{~A})$ : To a dry $100 \mathrm{~mL}$ round bottom flask was added $3.92 \mathrm{~g}(19.38 \mathrm{mmol})$ of alkyne $\mathbf{5 A}$ and $40 \mathrm{~mL}$ of $\mathrm{pH} 7.0$ phosphate buffer. To this solution was added a slurried mixture of $43 \mathrm{mg}$ of ChiroCLEC-PC (dry) and $2.0 \mathrm{~mL}$ of storage buffer $\left(1.0 \mathrm{~mL}\right.$ of $10 \mathrm{mM} \mathrm{CaCl}_{2}$ and $1.0 \mathrm{~mL}$ of $\mathrm{pH} 6.02,10 \mathrm{mM}$ TRIS). The reaction mixture was allowed to stir for $141 \mathrm{~h}$ at room temperature. The solution was filtered and the products were extracted $2 \times 50 \mathrm{~mL}$ of ether, dried $\left(\mathrm{MgSO}_{4}\right)$, and concentrated in vacuo. The products were separated by flash column chromatography on silica $(15 \times 2.5 \mathrm{~cm}$ of silica in 1:4 ethyl acetate/hexanes) producing $2.07 \mathrm{~g}$ of $(R)$-acetate $R-5 \mathrm{~A}^{4}$ $(53 \%), 88 \%$ ee by HPLC $((R, R)$-Whelk-O1, $1 \%$ IPA-hexanes, $1 \mathrm{~mL} / \mathrm{min})$, and $1.40 \mathrm{~g}$ of $(S)$-alcohol $S-19$. Analytical TLC: $(R)$-acetate $R-5 A R_{\mathrm{f}}=0.44$ (1:4 ethyl acetate/hexanes), $(S)$-alcohol $S$-19 $R_{\mathrm{f}}=0.23$ (1:4 ethyl acetate/hexanes). NMR data of $R-5 \mathrm{~A}$ matched that reported in literature: ${ }^{41} \mathrm{H}$ NMR $\left(500 \mathrm{MHz}, \mathrm{CDCl}_{3}, \mathrm{ppm}\right)$ $\delta 7.30(\mathrm{t}, 2 \mathrm{H}, \mathrm{J}=7.5 \mathrm{~Hz}), 7.21(\mathrm{t}, 3 \mathrm{H}, \mathrm{J}=7.5 \mathrm{~Hz}), 5.36(\mathrm{dt}, 1 \mathrm{H}, \mathrm{J}=6.5 \mathrm{~Hz}, 1.5$ $\mathrm{Hz}), 2.80(\mathrm{t}, 2 \mathrm{H}, \mathrm{J}=7.5 \mathrm{~Hz}), 2.52(\mathrm{~d}, 1 \mathrm{H}, \mathrm{J}=1.5 \mathrm{~Hz}), 2.15-2.09(\mathrm{~m}, 2 \mathrm{H}), 2.09(\mathrm{~s}$, $1 \mathrm{H}) ;[\alpha]_{\mathrm{D}}+34^{\circ}\left(\mathrm{c} 1.0, \mathrm{CHCl}_{3}\right)$.

(R)-5-Phenylpent-1-yn-3-yl propionate (S3): To a dry $50 \mathrm{~mL}$ round bottom flask was added a solution of $17 \mathrm{~mL}$ of methanol and $678 \mathrm{mg}(3.35 \mathrm{mmol})$ of $R-5 \mathrm{~A}$. To this solution was added $937 \mathrm{mg}(6.70 \mathrm{mmol})$ of $\mathrm{K}_{2} \mathrm{CO}_{3}$ and the contents were stirred for $1.3 \mathrm{~h}$ at room temperature. The product was extracted with $2 \times 50 \mathrm{~mL}$ of diethyl ether and washed with $50 \mathrm{~mL}$ of water. The organic layer was collected and washed with $50 \mathrm{~mL}$ of saturated $\mathrm{NH}_{4} \mathrm{Cl}$, dried $\left(\mathrm{Na}_{2} \mathrm{SO}_{4}\right)$, and concentrated. This gave $505 \mathrm{mg}(94 \%)$ of crude alcohol $R-19$. The sample was $>95 \%$ pure by ${ }^{1} \mathrm{H}$ NMR and was carried onto the next reaction. Analytical TLC: $\mathrm{R}_{\mathrm{f}}=0.24$ (1:4 ethyl acetate in hexanes). Next, a solution of $4.2 \mathrm{~mL}$ of $\mathrm{CH}_{2} \mathrm{Cl}_{2}$ and $505 \mathrm{mg}$ (3.15

${ }^{4}$ Smulik, J. A.; Diver, S.T. J. Org. Chem. 2000, 65, 1788-1792. 
mmol) of crude alcohol $R-19$ was added to a dry $25 \mathrm{~mL}$ round bottom flask and stirred at $0{ }^{\circ} \mathrm{C}$. To this solution was added dropwise $0.659 \mathrm{~mL}(4.73 \mathrm{mmol})$ of triethylamine followed by $39 \mathrm{mg}(0.32 \mathrm{mmol})$ of DMAP, added in one portion. Exactly $1.10 \mathrm{~mL}$ ( $12.61 \mathrm{mmol}$ ) of propionyl chloride was added dropwise over 10 min and allowed to stir at $0{ }^{\circ} \mathrm{C}$ for another $30 \mathrm{~min}$. The reaction was allowed to room temperature and stirred for $24 \mathrm{~h}$. The products were extracted with $2 \times 30$ $\mathrm{mL}$ of diethyl ether and washed with $30 \mathrm{~mL}$ of $1 \mathrm{M} \mathrm{HCl}$. The combined ether layers were dried $\left(\mathrm{Na}_{2} \mathrm{SO}_{4}\right)$ and concentrated in vacuo. The crude was purified via flash column chromatography on silica $(5 \times 2.5 \mathrm{~cm}$ of silica in 1:4 ethyl acetate in hexanes) affording $652 \mathrm{mg}(96 \%)$ of alkyne S3. Analytical TLC: $R_{f}=$ 0.53 (1:4 ethyl acetate in hexanes). ${ }^{1} \mathrm{H}$ NMR $\left(500 \mathrm{MHz}, \mathrm{CDCl}_{3}, \mathrm{ppm}\right) \delta 7.31$ (t, $2 \mathrm{H}, \mathrm{J}=7.5 \mathrm{~Hz}), 7.22(\mathrm{t}, 3 \mathrm{H}, \mathrm{J}=7.5 \mathrm{~Hz}), 5.39(\mathrm{dt}, 1 \mathrm{H}, \mathrm{J}=6.5 \mathrm{~Hz}, 2.0 \mathrm{~Hz}), 2.81(\mathrm{t}$, $2 \mathrm{H}, \mathrm{J}=8 \mathrm{~Hz}), 2.52(\mathrm{~d}, 1 \mathrm{H}, \mathrm{J}=2 \mathrm{~Hz}), 2.37(\mathrm{dq}, 2 \mathrm{H}, \mathrm{J}=7.5 \mathrm{~Hz}, 4 \mathrm{~Hz}), 2.13(\mathrm{~m}$, $2 \mathrm{H}), 1.18(\mathrm{t}, 3 \mathrm{H}, \mathrm{J}=7.5 \mathrm{~Hz}) ;{ }^{13} \mathrm{C}$ NMR $\left(75.5 \mathrm{MHz}, \mathrm{CDCl}_{3}, \mathrm{ppm}\right) \delta 173.2,140.6$, 128.4, 128.3, 126.1, 81.0, 73.8, 63.1, 36.1, 31.1, 27.4, 8.9; IR $\left(\mathrm{CH}_{2} \mathrm{Cl}_{2}, \mathrm{~cm}^{-1}\right)$ 3294, 3066, 3028, 2984, 2940, 2127, 1742, 1603, 1496, 1451, 1364, 1174, 1080, 1036, 752, 701; ESI-MS molecular ion calculated for $\mathrm{C}_{14} \mathrm{H}_{16} \mathrm{O}_{2} 216.11$, found $216.11(\mathrm{M})$, error $-2.0 \mathrm{ppm}$.

( $R$ )-4-Methylene-1-phenylhex-5-en-3-yl propionate $(\boldsymbol{R}-20)$ : To an oven-dried Fischer-Porter reaction tube was added a solution of $290 \mathrm{mg}(1.34 \mathrm{mmol})$ of alkyne ent-S3 and $27 \mathrm{~mL}$ of dichloromethane. The flask was then sealed and pressurized with ethylene while flushing argon from the system. The ethylene pressure was then released slowly and $68 \mathrm{mg}(0.09 \mathrm{mmol})$ of catalyst 1 was added to the reaction mixture and sealed up once again. The flask was repressurized and flushed 6 times with ethylene, maintaining the pressure at 80 psig, and let stir for $6 \mathrm{~h}$ until completion by GC. The reaction was purged of ethylene concentrated and purified by flash column chromatography on silica (15 x $2.5 \mathrm{~cm}$ of silica in 1:8 ethyl acetate in hexanes) resulting in $308 \mathrm{mg}(94 \%)$ of pure diene $R-20$, determined to be $94 \%$ ee by HPLC $((R, R)$-Whelk-O1, $1 \%$ IPA in hexanes, $0.5 \mathrm{~mL} / \mathrm{min}$ ). $\mathrm{GC}$ analysis (ret. time $=14.63 \mathrm{~min}$ ). Analytical TLC: $R_{\mathrm{f}}=$ 0.56 (1:4 ethyl acetate in hexanes). ${ }^{1} \mathrm{H}$ NMR $\left(500 \mathrm{MHz}, \mathrm{CDCl}_{3}, \mathrm{ppm}\right) \delta 7.30$ (t, $2 \mathrm{H}, \mathrm{J}=7.5 \mathrm{~Hz}), 7.21-7.17(\mathrm{~m}, 3 \mathrm{H}), 6.32(\mathrm{dd}, 1 \mathrm{H}, \mathrm{J}=17.5 \mathrm{~Hz}, 11 \mathrm{~Hz}), 5.53(\mathrm{t}, 1 \mathrm{H}$, $\mathrm{J}=6.5 \mathrm{~Hz}), 5.28(\mathrm{~d}, 1 \mathrm{H}, \mathrm{J}=17.5 \mathrm{~Hz}), 5.19(\mathrm{~d}, 2 \mathrm{H}, \mathrm{J}=7.5 \mathrm{~Hz}), 5.11(\mathrm{~d}, 1 \mathrm{H}, \mathrm{J}=$ $11 \mathrm{~Hz}$ ), 2.73-2.60 (m, 2H), $2.37(\mathrm{q}, 2 \mathrm{H}, \mathrm{J}=7.5 \mathrm{~Hz}), 2.05$ (dt, $2 \mathrm{H}, \mathrm{J}=7.5 \mathrm{~Hz}), 1.18$ (t, $3 \mathrm{H}, \mathrm{J}=7.5 \mathrm{~Hz}) ;{ }^{13} \mathrm{C}$ NMR $\left(75.5 \mathrm{MHz}, \mathrm{CDCl}_{3}, \mathrm{ppm}\right) \delta 173.4,145.3,141.2$, 135.5, 128.4, 128.3, 125.9, 115.1, 114.7, 72.5, 35.7, 31.8, 27.7, 9.1; IR $\left(\mathrm{CH}_{2} \mathrm{Cl}_{2}\right.$, $\mathrm{cm}^{-1}$ ) 3095, 3033, 2980, 2940, 2861, 1743, 1598, 1493, 1453, 1361, 1209, 1085, $1025,913,755,702$; ESI-MS molecular ion calculated for $\mathrm{C}_{16} \mathrm{H}_{20} \mathrm{O}_{2} 244.15$, found $244.15(\mathrm{M})$, error $0.5 \mathrm{ppm} ;[\alpha]_{\mathrm{D}}-10^{\circ}\left(\mathrm{c} 1.0, \mathrm{CHCl}_{3}\right)$.

(R,Z)-2-Methyl-7-phenyl-4-vinylhept-4-enoic acid (S4): To a dry $100 \mathrm{~mL}$ Schlenk tube was added a solution of $28 \mathrm{~mL}$ of diethyl ether and $208 \mathrm{mg}(0.85$ 
mmol) of diene $R-20$ and cooled to $-78^{\circ} \mathrm{C}$. In a separate $50 \mathrm{~mL}$ Schlenk tube, a solution of $0.5 \mathrm{M}$ KHMDS in toluene was made from solid KHMDS under inert atmosphere. Exactly $3.74 \mathrm{~mL}(1.87 \mathrm{mmol})$ of the KHMDS solution was added to the reaction slowly via syringe over $10 \mathrm{~min}$. and allowed to stir for an additional 5 min. Chlorotrimethylsilane $(0.348 \mathrm{~mL}, 2.72 \mathrm{mmol})$ was then added to the reaction. The reaction was allowed to warm to room temperature and stirred for $33 \mathrm{~h}$. The products were then extracted with $2 \times 50 \mathrm{~mL}$ diethyl ether and washed successively with $50 \mathrm{~mL} \mathrm{NH} \mathrm{Cl}_{4}$ and $50 \mathrm{~mL}$ of water. The combined organic layers were dried $\left(\mathrm{MgSO}_{4}\right)$, concentrated, and purified by flash column chromatography $(15 \times 2.5 \mathrm{~cm}$ of silica in 1:5 then $1: 1$ ethyl acetate in hexanes) providing $171 \mathrm{mg}$ $(82 \%)$ of carboxylic acid S4. Analytical TLC: $R_{f}=0.10$ (1:4 ethyl acetate in hexanes). ${ }^{1} \mathrm{H}$ NMR $\left(500 \mathrm{MHz}, \mathrm{CDCl}_{3}, \mathrm{ppm}\right) \delta 7.30(\mathrm{t}, 2 \mathrm{H}, \mathrm{J}=7.5 \mathrm{~Hz}), 7.20(\mathrm{~m}$, $3 \mathrm{H}), 6.62(\mathrm{dd}, 1 \mathrm{H}, \mathrm{J}=17.5 \mathrm{~Hz}, 11 \mathrm{~Hz}), 5.48(\mathrm{t}, 1 \mathrm{H}, \mathrm{J}=7.0 \mathrm{~Hz}), 5.25(\mathrm{~d}, 1 \mathrm{H}, \mathrm{J}=$ $17.5 \mathrm{~Hz}), 5.13(\mathrm{~d}, 1 \mathrm{H}, \mathrm{J}=11 \mathrm{~Hz}), 2.76-2.68(\mathrm{~m}, 4 \mathrm{H}), 2.50(\mathrm{q}, 2 \mathrm{H}, \mathrm{J}=8.0 \mathrm{~Hz})$, $2.18(\mathrm{dd}, 1 \mathrm{H}, \mathrm{J}=13 \mathrm{~Hz}, 8.0 \mathrm{~Hz}), 1.13(\mathrm{~d}, 3 \mathrm{H}, \mathrm{J}=7.0 \mathrm{~Hz}) ;{ }^{13} \mathrm{C}$ NMR $(75.5 \mathrm{MHz}$, $\left.\mathrm{CDCl}_{3}, \mathrm{ppm}\right) \delta 183.1,141.6,134.0,132.0,131.9,128.4,128.3,125.9,114.0$, 38.2, 37.3, 35.9, 29.3, 16.4; IR $\left(\mathrm{CH}_{2} \mathrm{Cl}_{2}, \mathrm{~cm}^{-1}\right) 3079,3026,2907,2670,1709$, 1597, 1499, 1453, 1426, 1295, 1249, 1117, 1077, 913, 755, 702; ESI-MS molecular ion calculated for $\mathrm{C}_{16} \mathrm{H}_{20} \mathrm{O}_{2} 244.15$, found $244.14(\mathrm{M})$, error -3.4 ppm; $[\alpha]_{\mathrm{D}}+16^{\circ}\left(\mathrm{c} 1.0, \mathrm{CHCl}_{3}\right)$.

(S,Z)-Methyl 2-methyl-7-phenyl-4-vinylhept-4-enoate (S-21): In a dry 1 dram vial was added $0.26 \mathrm{~mL}$ of dichloromethane and $0.13 \mathrm{~mL}$ methanol to $64.7 \mathrm{mg}$ $(0.26 \mathrm{mmol})$ of $\mathbf{S} 4$ and the solution cooled to $0{ }^{\circ} \mathrm{C}$. A $2.0 \mathrm{M}$ solution of (trimethylsilyl)diazomethane $(0.265 \mathrm{~mL}, 0.53 \mathrm{mmol})$ was added dropwise via syringe, during which evolution of $\mathrm{N}_{2}$ gas is observed. The reaction was then stirred for $20 \mathrm{~min}$ at room temperature. The crude solution was then concentrated in vacuo (rotary evaporator) and purified by flash column chromatography on silica $(8.3 \times 2.5 \mathrm{~cm}$ of silica in 1:20 ethyl acetate in hexanes) affording $58.7 \mathrm{mg}(86 \%)$ of methyl ester $S-21$. Analytical tlc: $R_{\mathrm{f}}=0.50$ (1:4 ethyl acetate in hexanes). HPLC analysis of the methyl ester $S-21$ showed $73 \%$ ee (CHIRALCEL OJ, $1 \%$ IPA in hexanes, $0.3 \mathrm{~mL} / \mathrm{min}) .{ }^{1} \mathrm{H}$ NMR $\left(500 \mathrm{MHz}, \mathrm{CDCl}_{3}\right.$, ppm) $\delta 7.30(\mathrm{t}, 2 \mathrm{H}, \mathrm{J}=7.5 \mathrm{~Hz}), 7.19-7.17(\mathrm{~m}, 3 \mathrm{H}), 6.60(\mathrm{dd}, 1 \mathrm{H}, \mathrm{J}=17.5 \mathrm{~Hz}, 11$ $\mathrm{Hz}), 5.43(\mathrm{t}, 1 \mathrm{H}, \mathrm{J}=7.0 \mathrm{~Hz}), 5.22(\mathrm{~d}, 1 \mathrm{H}, \mathrm{J}=17.5 \mathrm{~Hz}), 5.10(\mathrm{~d}, 1 \mathrm{H}, \mathrm{J}=11 \mathrm{~Hz})$, $3.63(\mathrm{~s}, 3 \mathrm{H}), 2.70-2.63(\mathrm{~m}, 4 \mathrm{H}), 2.47(\mathrm{dq}, 2 \mathrm{H}, \mathrm{J}=7.5 \mathrm{~Hz}, 3.0 \mathrm{~Hz}), 2.16(\mathrm{dd}, 1 \mathrm{H}, \mathrm{J}$ $=13 \mathrm{~Hz}, 8.0 \mathrm{~Hz}), 1.08(\mathrm{~d}, 3 \mathrm{H}, \mathrm{J}=6.5 \mathrm{~Hz}) ;{ }^{13} \mathrm{C} \mathrm{NMR}\left(75.5 \mathrm{MHz}, \mathrm{CDCl}_{3}, \mathrm{ppm}\right) \delta$ 176.9, 141.6, 134.2, 132.1, 131.6, 128.3, 128.28, 125.8, 113.9, 51.4, 38.4, 37.6, 35.9, 29.3, 16.7; IR $\left(\mathrm{CH}_{2} \mathrm{Cl}_{2}, \mathrm{~cm}^{-1}\right) 3085,3027,2944,1735,1607,1498,1466$, 1364, 1261, 1204, 1172, 1121, 993, 910, 750, 705; ESI-MS molecular ion calculated for $\mathrm{C}_{17} \mathrm{H}_{22} \mathrm{O}_{2} 258.16$, found $284.15(\mathrm{M}+\mathrm{Na})$, error $1.9 \mathrm{ppm}$.

(S, Z)-2-Methyl-7-phenyl-4-vinylhept-4-en-1-ol (S-22). To a dry $20 \mathrm{~mL}$ vial was added a solution of $S-21,128 \mathrm{mg}(0.50 \mathrm{mmol})$, in $5 \mathrm{~mL}$ of ether and stirred at 0 
${ }^{\circ} \mathrm{C}$ for $10 \mathrm{~min}$. Lithium aluminum hydride, $74 \mathrm{mg}(1.98 \mathrm{mmol})$, was added to the reaction mixture portionwise until gas evolution had ceased. The reaction was then allowed to warm to room temperature and stirred for an additional $0.5 \mathrm{~h}$. The mixture was quenched by the addition of $5 \mathrm{~mL}$ of $1 \mathrm{M} \mathrm{HCl}$, diluted with $20 \mathrm{~mL}$ of water and subsequently extracted with $3 \times 50 \mathrm{~mL}$ portions of ether. The combined organic layers were dried $\left(\mathrm{Na}_{2} \mathrm{SO}_{4}\right)$ and concentrated in vacuo (rotary evaporator). The crude product was then purified by flash column chromatography on silica gel (2 g, 1:4 ethyl acetate-hexanes) affording $110 \mathrm{mg}$ $(96 \%)$ of alcohol (S-22) as a colorless oil. Analytical TLC: $R_{f}=0.29$ (1:4 ethyl acetate-hexanes). ${ }^{1} \mathrm{H}$ NMR $\left(500 \mathrm{MHz}, \mathrm{CDCl}_{3}\right.$, ppm) $\delta$ 7.31-7.27 (m, $\left.2 \mathrm{H}\right), 7.21$ $7.18(\mathrm{~m}, 3 \mathrm{H}), 6.64(\mathrm{dd}, \mathrm{J}=11.0 \mathrm{~Hz}, 17.5 \mathrm{~Hz}, 1 \mathrm{H}), 5.42(\mathrm{t}, \mathrm{J}=7.5 \mathrm{~Hz}, 1 \mathrm{H}), 5.24$ (d, J = 17.5 Hz, 1H), $5.11(\mathrm{dd}, \mathrm{J}=11.0 \mathrm{~Hz}, 1 \mathrm{H}), 3.48(\mathrm{dd}, \mathrm{J}=5.5 \mathrm{~Hz}, 11.0 \mathrm{~Hz}$, $1 \mathrm{H}$ ), $3.42(\mathrm{dd}, \mathrm{J}=5.5 \mathrm{~Hz}, 11.0 \mathrm{~Hz}, 1 \mathrm{H}), 2.71(\mathrm{t}, \mathrm{J}=8.0 \mathrm{~Hz}, 2 \mathrm{H}), 2.52(\mathrm{q}, \mathrm{J}=7.5$ $\mathrm{Hz}, 2 \mathrm{H}$ ), 2.33 (dd, J = 6.5 Hz, $13.5 \mathrm{~Hz}, 1 \mathrm{H}), 1.96$ (dd, J = $8.0 \mathrm{~Hz}, 13.5 \mathrm{~Hz}, 1 \mathrm{H}$ ), 1.85 (sext., $\mathrm{J}=6.5 \mathrm{~Hz}, 1 \mathrm{H}$ ), 1.45 (bs, $1 \mathrm{H}), 0.88(\mathrm{~d}, \mathrm{~J}=6.5 \mathrm{~Hz}, 3 \mathrm{H}) ;{ }^{13} \mathrm{C}$ NMR $\left(75.5 \mathrm{MHz}, \mathrm{CDCl}_{3}, \mathrm{ppm}\right) \delta 141.7,135.4,132.7,131.0,128.4,128.3,125.8,114.0$, 68.1, 37.6, 36.0, 34.5, 29.2, 16.8; IR $\left(\mathrm{CH}_{2} \mathrm{Cl}_{2}, \mathrm{~cm}^{-1}\right) 3355,3085,3026,2960$, 2927, 2868, 1644, 1598, 1493, 1453, 1381, 1032, 992, 907, 755, 696; ESI-MS molecular ion calculated for $\mathrm{C}_{16} \mathrm{H}_{22} \mathrm{O} 230.17$, found $230.17(\mathrm{M})$, error $2.6 \mathrm{ppm}$. $[\alpha]_{\mathrm{D}}^{25^{\circ} \mathrm{C}}=-2.1^{\circ}\left(\mathrm{c} 1.0, \mathrm{CHCl}_{3}\right)$. 


\section{Mosher Ester Analysis of 22}

For assignment of absolute configuration, analyses of the corresponding $(R)$ - and (S)-MTPA esters were conducted according to Kobayashi5: To a dry 1 dram vial was added a solution of $15.6 \mathrm{mg}(0.13 \mathrm{mmol})$ of 4(dimethylamino)pyridine, $40 \mathrm{mg}(0.19 \mathrm{mmol})$ of dicyclohexylcarbodiimide, and $14.0 \mathrm{mg}(0.06 \mathrm{mmol})$ of alcohol 22 in $400 \mathrm{~mL}$ of dichloromethane. A solution of $28 \mathrm{mg}(0.12 \mathrm{mmol})$ of $(R)-(+)$ - $\alpha$-methoxy- $\alpha$-(trifluoromethyl)phenylacetic acid in $400 \mathrm{~mL}$ of dichloromethane was added dropwise to the solution of 22 . The reaction was stirred for $24 \mathrm{~h}$, and concentrated in vacuo (rotary evaporator). The same procedure was repeated using (S)-(-)- $\alpha$-methoxy- $\alpha-$ (trifluoromethyl)phenylacetic acid with $19.4 \mathrm{mg}(0.08 \mathrm{mmol})$ of 22 . The crude MTPA esters were then analyzed separately by ${ }^{1} \mathrm{H}$ NMR spectroscopy without further purification, examining the $A B$ part of the $A B X$ systems corresponding to the diastereotopic methylene protons (adjacent to the chiral center).

Selected portion of the ${ }^{1} \mathrm{H}$ NMR spectrum of the (S)-MTPA ester of 22: ${ }^{1} \mathrm{H}$ $\operatorname{NMR}\left(500 \mathrm{MHz}, \mathrm{CDCl}_{3}, \mathrm{ppm}\right) \delta 4.16(\mathrm{dd}, \mathrm{J}=5.5 \mathrm{~Hz}, 11.0 \mathrm{~Hz}, 1 \mathrm{H}), 4.00$ (dd, J = $5.5 \mathrm{~Hz}, 11.0 \mathrm{~Hz}, 1 \mathrm{H}$ ); The separation of $v_{A}$ and $v_{B}$ was found to be $\delta \Delta=0.16 \mathrm{ppm}$.

Selected portion of the ${ }^{1} \mathrm{H}$ NMR spectrum of the $(R)$-MTPA ester of $22:{ }^{1} \mathrm{H}$ NMR (500 MHz, $\left.\mathrm{CDCl}_{3}, \mathrm{ppm}\right) \delta 4.09\left(\mathrm{AB}\right.$ quartet, $\mathrm{J}_{\mathrm{AB}}=10.7 \mathrm{~Hz}, \mathrm{~J}_{\mathrm{AX}}=5.3 \mathrm{~Hz}$, $1 \mathrm{H}), 4.06\left(A B\right.$ quartet, $\left.J_{B A}=10.7 \mathrm{~Hz}, J_{B X}=5.1 \mathrm{~Hz}, 1 \mathrm{H}\right)$. The separation of $v_{A}$ and $v_{B}$ was found to be $\delta \Delta=0.03$ ppm.

The crude (S)-MTPA-derived ester resulted in a large splitting of the diastereotopic oxymethylene protons similar in magnitude $(\Delta \delta)$ to that observed by Kobayashi et al. ${ }^{5}$ for the $S$-configuration. Also in accord with the predictive model, the $(R)$-MTPA-derived Mosher ester resulted in small chemical shift separation of $v_{A}$ and $v_{B}$, also leading to the assignment of the $S$-configuration. These observations led to the assignment of $(S)$-configuration to the chiral center in 22.

${ }^{5}$ Tsuda, M.; Toriyabe, Y.; Endo, T.; Kobayashi, J. Chem. Pharm. Bull. 2003, 51, 448-451. 
Determination of E/Z Ratio in Model Silyl Ketene Acetal S6<smiles>CCC(=O)OC1C[C@H](C(C)C)CCC1C</smiles>

S5
$\underset{\mathrm{Et}_{2} \mathrm{O},-78^{\circ} \mathrm{C} \text { to rt }}{\stackrel{\mathrm{KHMDS}, \mathrm{TMSCl}}{\longrightarrow}}$<smiles>C/C=C(\O[Na])OC1C[C@H](C(C)C)CCC1C</smiles>

E-S6<smiles>C/C=C(\O[Si])OC1C[C@H](C(C)C)CC[C@@H]1C</smiles>

$95: 5$

To a dry $25 \mathrm{~mL}$ Schlenk tube was added a solution of $33.8 \mathrm{mg}(0.16$ $\mathrm{mmol}$ ) propionate menthyl ester $\mathbf{S} 5^{6}$ in $5 \mathrm{~mL}$ of diethyl ether and allowed to stir at $-78{ }^{\circ} \mathrm{C}$. To this solution was introduced $0.636 \mathrm{~mL}(0.32 \mathrm{mmol})$ of a $0.5 \mathrm{M}$ solution of KHMDS in toluene via syringe over $5 \mathrm{~min}$ and let stir for $5 \mathrm{~min}$. Then, $0.061 \mathrm{~mL}$ $(0.48 \mathrm{mmol})$ of $\mathrm{TMSCl}$ was immediately added to the reaction. After stirring for 10 min the reaction vessel was concentrated. Under argon, approximately $0.6 \mathrm{~mL}$ of benzene- $d_{6}$ was added to the reaction and syringed into a dry NMR tube for analysis. Solvent suppression of any left over ether resulted in a 95:5 E:Z ratio by ${ }^{1} \mathrm{H}$ NMR. H NMR of menthyl propionate ester S5 matched that reported. $E$ and Z-enolate shifts matched similar compounds reported. ${ }^{1}{ }^{1} \mathrm{H}$ NMR $(500 \mathrm{MHz}$, $\left.\mathrm{CDCl}_{3}, \mathrm{ppm}\right) \mathrm{E}$-enolate $\delta 3.78\left(\mathrm{q}, 1 \mathrm{H}, \mathrm{J}=6.5 \mathrm{~Hz}, \mathrm{RCOC}=\mathrm{CHCH}_{3}\right)$, Z-enolate 3.57 (q, $1 \mathrm{H}, \mathrm{RCOC}=\mathrm{CHCH}_{3}$ ).

\footnotetext{
${ }^{6}$ Ishihara, K.; Kubota, M.; Kurihara, H.; Yamamoto, H. J. Org. Chem. 1996, 61, 4560-4567.

${ }^{7}$ Ireland, R. E.; Wipf, P.; Armstrong, J. D. III. J. Org. Chem. 1991, 56, 650-657.
} 


\section{Chiral Cyclohexadiene Diol Synthesis}

Scheme S3. Synthesis of Triene 26

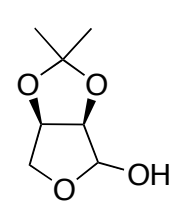

24

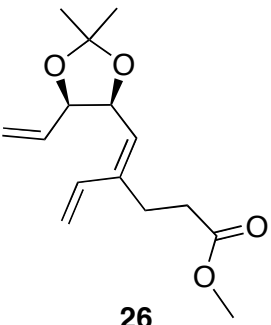

26

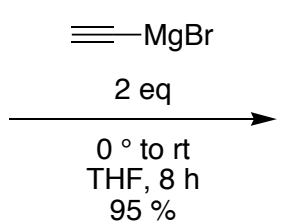

1.) 1.5 eq LiHMDS 1 eq HMPA 1.5 eq TBSCI

THF, $-78^{\circ} \mathrm{C}$ to rt, $19 \mathrm{~h}$

2.) 1.5 eq $\mathrm{KF} \cdot \mathrm{H}_{2} \mathrm{O}$ 1.5 eq $\mathrm{KHCO}_{3}$ 2 eq Mel $\mathrm{rt}, 18 \mathrm{~h}$ $62 \%$<smiles>C#CC(O)[C@H]1OC(C)(C)O[C@@H]1CO</smiles>

S7

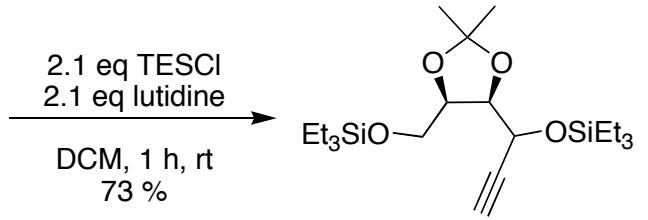

S8

$5 \%$ Ru gen-2 60 psig $\mathrm{C}_{2} \mathrm{H}_{4}$ DCM, $24 \mathrm{~h}, \mathrm{rt}$

$92 \%$<smiles>C#CC(O)[C@H]1OC(C)(C)O[C@@H]1CO</smiles>

S7

\section{1-((4S,5R)-5-(Hydroxymethyl)-2,2-dimethyl-1,3-dioxolan-4-yl)prop-2-yn-1-ol} (S7): To a $200 \mathrm{~mL}$, rb flask equipped with a magnetic stir bar and rubber septa, were added $1.60 \mathrm{~g} \mathrm{24} 4^{8}(10 \mathrm{mmol})$ and $100 \mathrm{~mL}$ tetrahydrofuran. The solution was cooled to $0{ }^{\circ} \mathrm{C}$ and $40 \mathrm{~mL}(10 \mathrm{mmol}, 2$ equiv) of a $0.5 \mathrm{M}$ solution of ethynlmagnesium bromide in diethyl ether was added dropwise via syringe. The solution was allowed to warm to ambient temperature and then stirred for $12 \mathrm{~h}$, at which time the starting material was consumed (GC analysis). The reaction was diluted with $40 \mathrm{~mL}$ of diethyl ether and quenched by the addition of $50 \mathrm{~mL}$ of a saturated $\mathrm{NH}_{4} \mathrm{Cl}$ solution. The organic phase was separated and the remaining aqueous phase was extracted with diethyl ether $(3 \mathrm{X} 100 \mathrm{~mL})$. The combined organic phases were washed with water then $100 \mathrm{~mL}$ of a saturated brine solution, dried $\left(\mathrm{Na}_{2} \mathrm{SO}_{4}\right)$ and concentrated in vacuo (rotary evaporator) to give a crude orange oil. The crude oil was purified by flash chromatography on silica gel $(4.2 \times 11 \mathrm{~cm}$ column, $1: 1$ ethyl acetate/ hexanes) to give $1.77 \mathrm{~g}$ (95\% yield) of the product $\mathbf{S} 7$ as a light yellow oil. Analytical TLC $\mathrm{R}_{\mathrm{f}} 0.31$ (1:1 ethyl acetate/

${ }^{8}$ Jeong, L. S. et al., J. Org. Chem. 2001, 66, 6490-6494. 
hexanes, $\mathrm{KMnO}_{4}$ visualization); $[\mathrm{a}]_{\mathrm{D}}{ }^{25}-31.1\left(\mathrm{c}=0.52, \mathrm{CHCl}_{3}\right)$; $\mathrm{GC}$ analysis (ret time $12.70 \mathrm{~min}) ;{ }^{1} \mathrm{H}$ NMR $\left(500 \mathrm{MHz}, \mathrm{CDCl}_{3}, \mathrm{ppm}\right) \delta 4.58(\mathrm{dd}, \mathrm{J}=7.0,2.0 \mathrm{~Hz}$, $1 \mathrm{H}), 4.33(\mathrm{dt} \mathrm{J}=10.5,6.5 \mathrm{~Hz}, 1 \mathrm{H}), 4.23(\mathrm{t}, \mathrm{J}=7.0 \mathrm{~Hz}, 1 \mathrm{H}), 3.96(\mathrm{dd}, \mathrm{J}=11.5,4.0$ $\mathrm{Hz}, 1 \mathrm{H}), 3.92(\mathrm{dd}, \mathrm{J}=12.0,6.0 \mathrm{~Hz}, 1 \mathrm{H}), 2.54(\mathrm{~d}, \mathrm{~J}=2.0 \mathrm{~Hz}, 1 \mathrm{H}), 1.50(\mathrm{~s}, 3 \mathrm{H})$, 1.39 (s, 3H); ${ }^{13} \mathrm{C}$ NMR (125 MHz, $\left.\mathrm{CDCl}_{3}, \mathrm{ppm}\right) \delta 108.84,82.12,78.80,76.86$, 74.33, 61.29, 60.14, 27.35, 25.04; FT-IR (thin film, $\mathrm{cm}^{-1}$ ) 3440, 3289, 2999, 2940, 2887, 1387, 1216, 1163, 1051, 854; High-resolution ESI molecular ion calculated for $\mathrm{C}_{9} \mathrm{H}_{14} \mathrm{O}_{4}+\mathrm{Na} 209.079$, found 209.078, error 0.8 ppm.

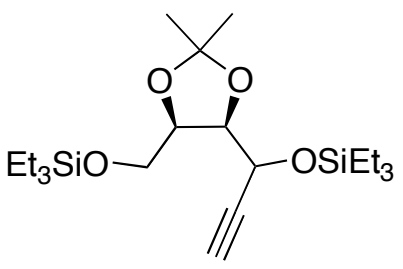

S8

(4R,5R)-2,2-Dimethyl-4-((triethylsilyloxy)methyl)-5-((R)-1-

(triethylsilyloxy)prop-2-ynyl)-1,3-dioxolane (S8): To a $200 \mathrm{~mL}$, rb flask containing a magnetic stir bar were added $1.39 \mathrm{~g} \mathrm{S7}(7.46 \mathrm{mmol})$ and $70 \mathrm{~mL}$ dichloromethane, followed by $2.18 \mathrm{~mL}$ triethylamine $(15.67 \mathrm{mmol}, 2.1$ equiv). After $15 \mathrm{~min}, 2.63 \mathrm{~mL}$ triethylchlorosilane $(15.67 \mathrm{mmol}, 2.1$ equiv) was added dropwise by syringe at room temperature. The reaction was stirred $19 \mathrm{~h}$ and was then quenched with a saturated $\mathrm{NH}_{4} \mathrm{Cl}$ solution. The crude organic solution was transferred to a separatory funnel and washed successively with water $(50 \mathrm{~mL})$ and brine $(50 \mathrm{~mL})$ and dried $\left(\mathrm{Na}_{2} \mathrm{SO}_{4}\right)$. The crude solution was concentrated in vacuo (rotary evaporator) to give a light orange oil which was purified by flash chromatography on silica gel $(4.2 \times 11 \mathrm{~cm}$ column, $1: 4$ ethyl acetate/ hexanes), providing $2.25 \mathrm{~g}$ (73\% yield) of product $\mathbf{S} 8$ as a light yellow oil. Analytical TLC $\mathrm{R}_{\mathrm{f}}$ 0.57 (1:4 ethyl acetate/ hexanes, $\mathrm{KMnO}_{4}$ visualization); $[\mathrm{a}]_{D}{ }^{25}+10.7(\mathrm{c}=0.56$, $\mathrm{CHCl}_{3}$ ); $\mathrm{GC}$ analysis (ret time $\left.16.67 \mathrm{~min}\right){ }^{1} \mathrm{H}$ NMR $\left(500 \mathrm{MHz}, \mathrm{CDCl}_{3}, \mathrm{ppm}\right) \delta 4.57$ $(\mathrm{dd}, \mathrm{J}=6.0,2.5 \mathrm{~Hz}, 1 \mathrm{H}), 4.28(\mathrm{~m}, 1 \mathrm{H}), 4.12(\mathrm{t}, \mathrm{J}=6.0 \mathrm{~Hz}, 1 \mathrm{H}), 4.04(\mathrm{dd}, \mathrm{J}=11.0$, $3.5 \mathrm{~Hz}, 1 \mathrm{H}), 3.80(\mathrm{dd}, \mathrm{J}=11.0,8.0 \mathrm{~Hz}, 1 \mathrm{H}), 2.46(\mathrm{~d}, \mathrm{~J}=1.5 \mathrm{~Hz}, 1 \mathrm{H}), 1.49(\mathrm{~s}, 3 \mathrm{H})$, $1.36(\mathrm{~s}, 3 \mathrm{H}), 0.97(\mathrm{q}, \mathrm{J}=8.0 \mathrm{~Hz}, 18 \mathrm{H}), 0.66(\mathrm{~m}, 12 \mathrm{H}) ;{ }^{13} \mathrm{C} \mathrm{NMR}\left(125 \mathrm{MHz}, \mathrm{CDCl}_{3}\right.$, ppm) $\delta 123.92,108.86,82.99,79.54,78.47,74.19,62.13,61.92,27.42,25.17$, 6.78, 4.88, 4.35; FT-IR (thin film, $\mathrm{cm}^{-1}$ ) 3309, 3276, 2954, 2882, 1485, 1420, $1374,155,1091,1031,738$; High-resolution MS ESI molecular ion calcd for $\mathrm{C}_{21} \mathrm{H}_{42} \mathrm{O}_{4} \mathrm{Si}_{2}+\mathrm{Na} 437.2519$, found 437.2514, error $2.7 \mathrm{ppm}$. 


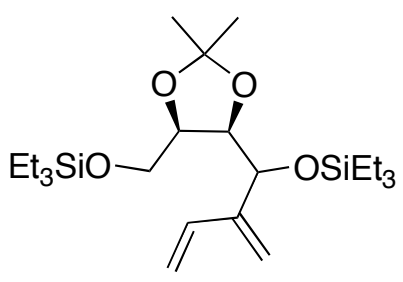

S9

(4R,5R)-2,2-Dimethyl-4-((R)-2-methylene-1-(triethylsilyloxy)but-3-enyl)-5((triethylsilyloxy)methyl)-1,3-dioxolane (S9): A $300 \mathrm{~mL}$ aerosol reaction vessel was charged with $3.81 \mathrm{~g} \mathbf{S 8}(9.18 \mathrm{mmol})$ and $90 \mathrm{~mL}$ dichloromethane. The vessel was sealed and charged to 80 psig with ethylene and purged (4X) to pre-saturate the solution with ethylene. The vessel was vented and $467 \mathrm{mg}$ Ru gen-2 (6 $\mathrm{mol} \%, 0.55 \mathrm{mmol}$ ) were added. The vessel was charged to $80 \mathrm{psig}$ with ethylene and the dark red solution was stirred for $24 \mathrm{~h}$, at which time the starting material was consumed (GC analysis). The crude reaction was filtered through a pad of silica gel $(7 \mathrm{~g})$ and $0.5 \mathrm{~mL}$ dimethylsulfoxide was added. After stirring for $24 \mathrm{~h}$, the crude solution was concentrated in vacuo (rotary evaporator) and the product was isolated by flash chromatography on silica gel ( $3 \times 18 \mathrm{~cm}$ column, $5 \%$ ethyl acetate/ hexanes) to give $3.11 \mathrm{~g}$ (92\% yield) of the diene S9 as a faint yellow oil. Analytical TLC $\mathrm{R}_{\mathrm{f}} 0.33$ (5\% ethyl acetate/ hexanes, $\mathrm{KMnO}_{4}$ visualization); [a] ${ }_{\mathrm{D}}{ }^{25}$ $+17.8\left(\mathrm{c}=0.56, \mathrm{CHCl}_{3}\right) ; \mathrm{GC}$ analysis (ret time $\left.17.49 \mathrm{~min}\right){ }^{1} \mathrm{H} \mathrm{NMR}(500 \mathrm{MHz}$, $\left.\mathrm{CDCl}_{3}, \mathrm{ppm}\right) \delta 6.34$ (dd, J = 17.5, $\left.11.0 \mathrm{~Hz}, 1 \mathrm{H}\right), 5.48$ (dd, J = 17.5, $0.5 \mathrm{~Hz}, 1 \mathrm{H}$ ), $5.28(\mathrm{~s}, 1 \mathrm{H}), 5.20(\mathrm{~s}, 1 \mathrm{H}), 5.12(\mathrm{~d}, \mathrm{~J}=11.5 \mathrm{~Hz}, 1 \mathrm{H}), 4.50(\mathrm{~d}, \mathrm{~J}=6.5 \mathrm{~Hz}, 1 \mathrm{H}), 4.18$ $(\mathrm{m}, 2 \mathrm{H}), 3.99$ (dd, J = 11.0, 2.0 Hz, 1H), $3.77(\mathrm{dd}, \mathrm{J}=11.5,8.0 \mathrm{~Hz}, 1 \mathrm{H}), 1.43(\mathrm{~s}$, $3 \mathrm{H}), 1.31(\mathrm{~s}, 3 \mathrm{H}), 0.95(\mathrm{~m}, 18 \mathrm{H}), 0.63(\mathrm{t}, \mathrm{J}=8.0 \mathrm{~Hz}, 6 \mathrm{H}), 0.58(\mathrm{t}, \mathrm{J}=8.0 \mathrm{~Hz}, 6 \mathrm{H})$; ${ }^{13} \mathrm{C}$ NMR $\left(125 \mathrm{MHz}, \mathrm{CDCl}_{3}, \mathrm{ppm}\right) \delta 146.63,135.48,116.81,115.28,108.10$, 79.25, 78.35, 72.13, 62.51, 27.83, 25.32, 6.89, 6.72, 4.96, 4.38; FT-IR (thin film, $\mathrm{cm}^{-1}$ ) 2960, 2920, 2874, 1472, 1426, 1380, 1241, 1209, 1143, 1083, 1004, 912, 827, 741; High-resolution MS ESI molecular ion calcd for $\mathrm{C}_{23} \mathrm{H}_{46} \mathrm{O}_{4} \mathrm{Si}_{2}+\mathrm{Na}$ 465.2832, found 465.2827, error $1.0 \mathrm{ppm}$.

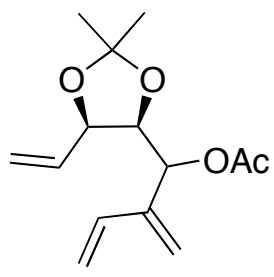

25

(R)-1-((4R,5R)-2,2-Dimethyl-5-vinyl-1,3-dioxolan-4-yl)-2-methylenebut-3-enyl acetate (25): To a $25 \mathrm{~mL}$ rb flask containing $25 \mathrm{~mL}$ dichloromethane, cooled to $78{ }^{\circ} \mathrm{C}$, were added $10 \mathrm{~mL}$ (19.9 mmol, 4.4 equiv) of $2 \mathrm{M}$ oxalyl chloride in dichloromethane and $2.8 \mathrm{~mL}$ (39.6 mmol, 8.8 equiv) dimethylsulfoxide. The

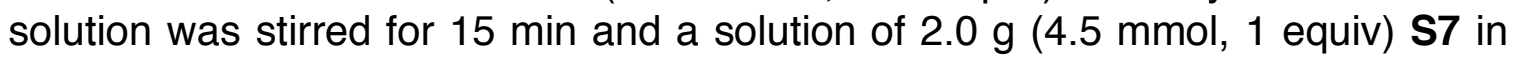
$20 \mathrm{~mL}$ dichloromethane was added slowly (ca. $5 \mathrm{~min}$ ) by syringe. The solution 
was maintained at $-78{ }^{\circ} \mathrm{C}$ for $20 \mathrm{~min}$ and was allowed to warm to $-40{ }^{\circ} \mathrm{C}$. The solution was kept at $-40{ }^{\circ} \mathrm{C}$ for $30 \mathrm{~min}$, at which time the starting material was consumed (TLC). The reaction was cooled to $-78^{\circ} \mathrm{C}$ and $9.4 \mathrm{~mL}(67.5 \mathrm{mmol}, 15$ equiv) of triethylamine were added. The reaction was removed from the cooling bath and allowed to come to room temperature. The reaction was quenched by the addition of $40 \mathrm{~mL}$ of a saturated $\mathrm{NH}_{4} \mathrm{Cl}$ solution. The organic phase was treated with water $(60 \mathrm{~mL})$ and brine $(2 \times 50 \mathrm{~mL})$ and then dried $\left(\mathrm{Na}_{2} \mathrm{SO}_{4}\right)$. The crude aldehyde solution was diluted with $40 \mathrm{~mL}$ tetrahydrofuran and the dichloromethane was removed by rotary evaporation, at reduced pressure (500 $\mathrm{mmHg}, 35^{\circ} \mathrm{C}$ ), leaving approximately $38 \mathrm{~mL}$ crude solution.

To a $100 \mathrm{~mL}$, three-neck rb flask equipped with a $125 \mathrm{~mL}$, pressureequalizing addition funnel were added, $4.82 \mathrm{~g}$ (13.5 mmol, 3 equiv) $\mathrm{Ph}_{3} \mathrm{PCH}_{3} \mathrm{Br}$ and $50 \mathrm{~mL}$ tetrahydrofuran. The slurry was cooled to $-78{ }^{\circ} \mathrm{C}$ and $6.0 \mathrm{~mL}(12.6$ mmol, 2.8 equiv) of $2.09 \mathrm{M} n$-butyllithium solution in hexanes was added slowly by syringe (ca. $10 \mathrm{~min}$ ). After the addition was complete, the reaction was allowed to warm to $\mathrm{rt}$ and stirred for $1 \mathrm{~h}$. The red phosphorane solution was returned to the $-78{ }^{\circ} \mathrm{C}$ bath and the addition funnel was charged with the aldehyde solution $(40 \mathrm{~mL})$ from above. The aldehyde solution was added dropwise over $30 \mathrm{~min}$ and the reaction was stirred at $-78{ }^{\circ} \mathrm{C}$ for $30 \mathrm{~min}$. The reaction was removed from the cooling bath and allowed to stir at ambient temperature for $3 \mathrm{~h}$. The reaction was quenched with water $(50 \mathrm{~mL})$ and the aqueous phase was extracted with diethyl ether $(3 \mathrm{X} 100 \mathrm{~mL})$. The combined organic phases were treated with brine $(200 \mathrm{~mL})$ and dried $\left(\mathrm{Na}_{2} \mathrm{SO}_{4}\right)$. The organics were filtered and stored at $-20{ }^{\circ} \mathrm{C}$ overnight. The crude organic slurry was filtered through a 3 " pad of silica gel $(5 \mathrm{~g})$ and the filtrate was concentrated (rotary evaporator) to give $0.60 \mathrm{~g}$ of a light orange oil. The presence of the desired product was verified by GC analysis (ret time $14.61 \mathrm{~min}$ ) and the crude oil was carried through to the next reaction without further purification.

To a $200 \mathrm{~mL}$ rb flask containing a magnetic stir bar were placed the crude triene from above $(0.60 \mathrm{~g})$ and $45 \mathrm{~mL}$ tetrahydrofuran. The solution was cooled to $0{ }^{\circ} \mathrm{C}$ in an ice bath and $5.0 \mathrm{~mL}(4.95 \mathrm{mmol}, 1.1$ equiv) of a $1 \mathrm{M}$ tetrabutylammonium fluoride solution in tetrahydrofuran was added dropwise via a polyethylene syringe. After $20 \mathrm{~min}$, the reaction was diluted with $50 \mathrm{~mL}$ ethyl acetate. The crude solution was washed successively with water $(30 \mathrm{~mL})$ and brine $(30 \mathrm{~mL})$, followed by drying $\left(\mathrm{Na}_{2} \mathrm{SO}_{4}\right)$ and filtration through a 1" pad of silica $(2 \mathrm{~g})$. Concentration (rotary evaporator) of the crude product gave $1.26 \mathrm{~g}$ of a light orange oil. The presence of the crude product was verified by GC analysis (ret time $12.28 \mathrm{~min}$ ) and the compound was used in the next reaction without further purification.

To a $200 \mathrm{~mL}$, rb flask were added the crude alcohol from the previous reaction $(1.26 \mathrm{~g}), 45 \mathrm{~mL}$ dichloromethane and $1.35 \mathrm{~mL}$ triethylamine $(13.5 \mathrm{mmol}$, 3 equiv). After $5 \mathrm{~min}, 1.3 \mathrm{~mL}$ acetic anhydride (13.5 mmol, 3 equiv) and $55 \mathrm{mg}$ dimethylaminopyridine $(0.45 \mathrm{mmol}, 10 \mathrm{~mol} \%)$ were added to the flask and the reaction was stirred $12 \mathrm{~h}$ at ambient temperature. The reaction was quenched 
with saturated $\mathrm{NH}_{4} \mathrm{Cl}$ solution $(100 \mathrm{~mL}$ ) and the crude organic solution was washed with sodium bicarbonate solution $(2 \mathrm{X} 50 \mathrm{~mL})$, water $(100 \mathrm{~mL})$ and brine $(2 \times 50 \mathrm{~mL})$ and then dried $\left(\mathrm{Na}_{2} \mathrm{SO}_{4}\right)$. Concentration (rotary evaporator) of the crude solution gave a light yellow oil which was purified by flash chromatography on silica gel $(4.2 \times 21 \mathrm{~cm}$ column, $1: 4$ ethyl acetate/ hexanes with $1 \%$ triethylamine) giving $459.2 \mathrm{mg}$ (40\% yield, 4 steps) of 25 as a light yellow oil. Analytical TLC $\mathrm{R}_{\mathrm{f}} 0.4$ (1:4 ethyl acetate/ hexanes, $\mathrm{KMnO}_{4}$ visualization); [a] $]_{\mathrm{D}}{ }^{25}$ $44.6\left(\mathrm{c}=0.56, \mathrm{CHCl}_{3}\right)$; $\mathrm{GC}$ analysis (ret time $\left.14.61 \mathrm{~min}\right) ;{ }^{1} \mathrm{H}$ NMR $(500 \mathrm{MHz}$, $\left.\mathrm{CDCl}_{3}, \mathrm{ppm}\right) \delta 6.34$ (dd, $\left.\mathrm{J}=17.5,11.0 \mathrm{~Hz}, 1 \mathrm{H}\right), 5.83$ (ddd, $\mathrm{J}=17.0,10.0,7.5 \mathrm{~Hz}$, $1 \mathrm{H}), 5.53(\mathrm{~d}, \mathrm{~J}=17.5 \mathrm{~Hz}, 1 \mathrm{H}), 5.37(\mathrm{dd}, \mathrm{J}=17.5,1.0 \mathrm{~Hz}, 1 \mathrm{H}), 5.34(\mathrm{~s}, 1 \mathrm{H}), 5.30$ (d, J = 10.0 Hz, 1H), $5.25(\mathrm{~s}, 1 \mathrm{H}), 5.23(\mathrm{~d}, \mathrm{~J}=11.0 \mathrm{~Hz}, 1 \mathrm{H}), 5.15(\mathrm{~d}, \mathrm{~J}=11.0 \mathrm{~Hz}$, $1 \mathrm{H}), 4.68(\mathrm{t}, \mathrm{J}=6.5 \mathrm{~Hz}, 1 \mathrm{H}), 4.40(\mathrm{dd}, \mathrm{J}=9.5,6.5 \mathrm{~Hz}, 1 \mathrm{H}), 1.98(\mathrm{~s}, 3 \mathrm{H}), 1.46(\mathrm{~s}$, $3 \mathrm{H}), 1.35$ (s, 3H); ${ }^{13} \mathrm{C}$ NMR (125 MHz, $\left.\mathrm{CDCl}_{3}, \mathrm{ppm}\right) \delta$ 169.0, 143.3, 135.2, 132.7, 118.2, 118.1, 115.6, 109.1, 78.9, 77.8, 71.7, 27.6, 25.1, 20.9; FT-IR (thin film, $\mathrm{cm}^{-}$ $\left.{ }^{1}\right) 3098.4,2999.6,2940.4,2887.8,1762.3,1597.8,1433.3,1374.0,1222.7$, 1163.4, 1038.4, 998.9, 919.9, 873.9; High-resolution MS ESI molecular ion calcd for $\mathrm{C}_{14} \mathrm{H}_{20} \mathrm{O}_{4}+\mathrm{Na} 275.1259$, found 275.1259, error $0.0 \mathrm{ppm}$.

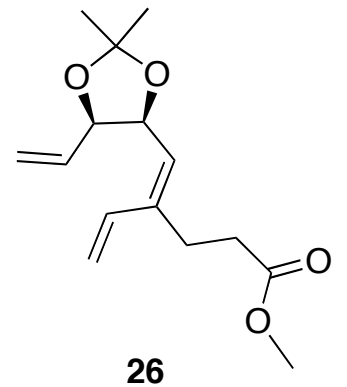

(Z)-Methyl 4-(( (4S,5R)-2,2-dimethyl-5-vinyl-1,3-dioxolan-4-yl)methylene)hex5-enoate (26): To a $10 \mathrm{~mL}$ rb flask was added, $1.5 \mathrm{~mL} 1 \mathrm{M}$ LiHMDS solution in tetrahydrofuran ( $1.5 \mathrm{mmol}, 1.5$ equiv). The solution was cooled in a $-78{ }^{\circ} \mathrm{C}$ bath for $5 \mathrm{~min}$ and $0.174 \mathrm{~mL}$ HMPA (1.0 mmol, 1 equiv) was added via microliter syringe. After $15 \mathrm{~min}$, a solution of $252 \mathrm{mg} 25$ (1.0 mmol, 1 equiv), $226 \mathrm{mg} \mathrm{t}$ butyldimethylchlorosilane (1.5 mmol, 1.5 equiv) and $1.0 \mathrm{~mL}$ tetrahydrofuran was added by syringe. After $15 \mathrm{~min}$, the reaction was removed from the cooling bath and stirred at it for $19 \mathrm{~h}$, at which time the starting material was consumed (TLC analysis). The reaction was quenched with $10 \mathrm{~mL}$ water and the aqueous phase was extracted with pentane $(4 \times 10 \mathrm{~mL})$. The combined organics were dried $\left(\mathrm{Na}_{2} \mathrm{SO}_{4}\right)$ and concentrated in vacuo (rotary evaporator) to give an orange oil. The crude oil was diluted with $3.0 \mathrm{~mL} \mathrm{HMPA}$ and $150 \mathrm{mg} \mathrm{KHCO}_{3}(1.5 \mathrm{mmol}, 1.5$ equiv) and $141 \mathrm{mg} \mathrm{KF} \mathrm{K}_{2} \cdot \mathrm{H}_{2} \mathrm{O}$ (1.5 mmol, 1.5 equiv) were added. After stirring 40 min, $0.12 \mathrm{~mL}$ iodomethane $(2.0 \mathrm{mmol}, 2.0$ equiv) was added by microliter syringe. The reaction was stirred $18 \mathrm{~h}$ at ambient temperature, at which time, the reaction was complete (TLC analysis). The reaction was quenched by the addition of $15 \mathrm{~mL}$ water. The aqueous phase was extracted with pentane $(5 \times 20$ $\mathrm{mL})$ and the combined organic phases were dried $\left(\mathrm{Na}_{2} \mathrm{SO}_{4}\right)$. The crude product was concentrated to give an orange oil which was purified by flash 
chromatography on silica gel ( $3 \times 13 \mathrm{~cm}$ column, 1:4 ethyl acetate/ hexanes) to give $166 \mathrm{mg}(62 \%$ yield) of the product as a faint yellow oil. The triene $\mathbf{2 6}$ was isolated as a 10:1 mixture of stereoisomers. Analytical TLC $R_{f} 0.44$ (1:4 ethyl acetate/ hexanes, $\mathrm{KMnO}_{4}$ visualization); $\mathrm{GC}$ analysis (ret time 14.22,14.33 min); NMR Data for the major isomer: ${ }^{1} \mathrm{H}$ NMR $\left(500 \mathrm{MHz}, \mathrm{CDCl}_{3}, \mathrm{ppm}\right) \delta 6.55$ (dd, $\mathrm{J}=$ 17.5, $11.0 \mathrm{~Hz}, 1 \mathrm{H}$ ), 5.71 (ddd, $\mathrm{J}=17.0,10.0,7.0,1 \mathrm{H}$ ), $5.37(\mathrm{~d}, \mathrm{~J}=8.5 \mathrm{~Hz}, 1 \mathrm{H}$ ), $5.30(\mathrm{~d}, \mathrm{~J}=17.5 \mathrm{~Hz}, 1 \mathrm{H}), 5.63(\mathrm{~d}, \mathrm{~J}=17.0,1 \mathrm{H}), 5.21(\mathrm{~d}, \mathrm{~J}=11,1 \mathrm{H}), 5.17(\mathrm{~d}, \mathrm{~J}=$ 10.5, 1H), $5.07(\mathrm{dd}, \mathrm{J}=8.5,6.5 \mathrm{~Hz}, 1 \mathrm{H}), 4.56(\mathrm{t}, \mathrm{J}=6.5 \mathrm{~Hz}, 1 \mathrm{H}), 3.66(\mathrm{~s}, 3 \mathrm{H})$, $2.55(\mathrm{~m}, 2 \mathrm{H}), 2.46(\mathrm{~m}, 2 \mathrm{H}), 1.51(\mathrm{~s}, 3 \mathrm{H}), 1.39(\mathrm{~s}, 3 \mathrm{H}) ;{ }^{13} \mathrm{C}$ NMR $(125 \mathrm{MHz}$, $\left.\mathrm{CDCl}_{3}, \mathrm{ppm}\right) \delta 173.37,139.16,134.14,131.81,125.63,118.03,116.29,108.73$, 79.95, 74.07, 51.58, 33.15, 28.44, 28.07, 25.52; FT-IR (thin film, $\mathrm{cm}^{-1}$ ) 3098, 2986, 2953, 1748, 1439, 1360, 1248, 1215, 1169, 1057, 991, 925, 879; Highresolution MS ESI molecular ion calcd for $\mathrm{C}_{15} \mathrm{H}_{22} \mathrm{O}_{4}+\mathrm{Na} 289.1416$, found 289.1423, error $2.4 \mathrm{ppm}$.

Major isomer of 26: The regiochemical assignment of the major isomer was supported by nOe studies. Irradiation of the vinylic proton at $\delta 5.37 \mathrm{ppm}$ gave nOe enhancement of the methine resonance at $\delta 5.07 \mathrm{ppm}$ and the allylic methylene protons appearing at $\delta 2.55 \mathrm{ppm}$.

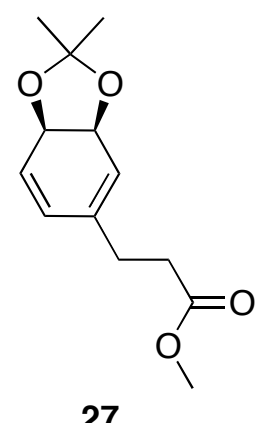

27

Methyl-3-((3aS,7aR)-2,2-dimethyl-3a,7a-dihydrobenzo[d][1,3]dioxol-5-

yl)propanoate (27): To a $50 \mathrm{~mL}$ Schlenk flask, equipped with a magnetic stir bar, were added $25 \mathrm{mg} 26(0.094 \mathrm{mmol})$ and $1 \mathrm{~mL}$ dichloromethane, followed by $4.8 \mathrm{mg}$ Ru gen-2 $(0.006 \mathrm{mmol}, 6 \mathrm{~mol} \%)$. The flask was fit with a cold finger condenser and the reaction was placed in a $40{ }^{\circ} \mathrm{C}$ oil bath. After $2 \mathrm{~h}$, the reaction was complete (TLC analysis) $1 \mathrm{~mL}$ of ethyl vinyl ether was added to deactivate the catalyst and the crude reaction was then passed through a plug of silica and concentrated. The crude product was purified by flash chromatography on silica gel $(2.8 \times 10 \mathrm{~cm}$ column, $1: 4$ ethyl acetate/ hexanes) to give $11.1 \mathrm{mg}$ (50\% yield) of the cyclohexadiene 27 as a clear oil. Analytical TLC $R_{f} 0.49$ (1:4 ethyl acetate/ hexanes, $\mathrm{I}_{2}$ visualization); $[\mathrm{a}]_{\mathrm{D}}^{25}-10.5\left(\mathrm{c}=0.40, \mathrm{CHCl}_{3}\right) ; \mathrm{GC}$ analysis (ret time $14.10 \mathrm{~min}$ ); ${ }^{1} \mathrm{H}$ NMR (500 MHz, $\left.\mathrm{CDCl}_{3}, \mathrm{ppm}\right) \delta 5.88$ (dd, J = 10.0, $\left.2.5 \mathrm{~Hz}, 1 \mathrm{H}\right)$, $5.85(\mathrm{~d}, \mathrm{~J}=9.5 \mathrm{~Hz}, 1 \mathrm{H}), 5.62(\mathrm{~s}, 1 \mathrm{H}), 4.62(\mathrm{~m}, 2 \mathrm{H}), 3.67(\mathrm{~s}, 3 \mathrm{H}), 2.45(\mathrm{~m}, 4 \mathrm{H})$, $1.40(\mathrm{~s}, 3 \mathrm{H}), 1.38(\mathrm{~s}, 3 \mathrm{H}) ;{ }^{13} \mathrm{C} \mathrm{NMR}\left(125 \mathrm{MHz}, \mathrm{CDCl}_{3}, \mathrm{ppm}\right) \delta 173.20,134.81$, 
126.44, 126.16, 119.33, 104.76, 70.55, 70.42, 51.70, 32.39, 30.57, 26.73, 24.75; FT-IR $\left(\mathrm{CHCl}_{3}, \mathrm{CaF}_{2}\right.$ cell, $\left.\mathrm{cm}^{-1}\right)$ 2951, 2940, 2917, 2906, 1738, 1444, 1387, 1370, $1268,1166,1053,1036$; High-resolution MS ESI molecular ion calcd for $\mathrm{C}_{13} \mathrm{H}_{18} \mathrm{O}_{4}+\mathrm{Na} 261.1103$, found 261.1101, error 0.8 ppm. 
Proton and Carbon NMR Spectra for New Compounds 


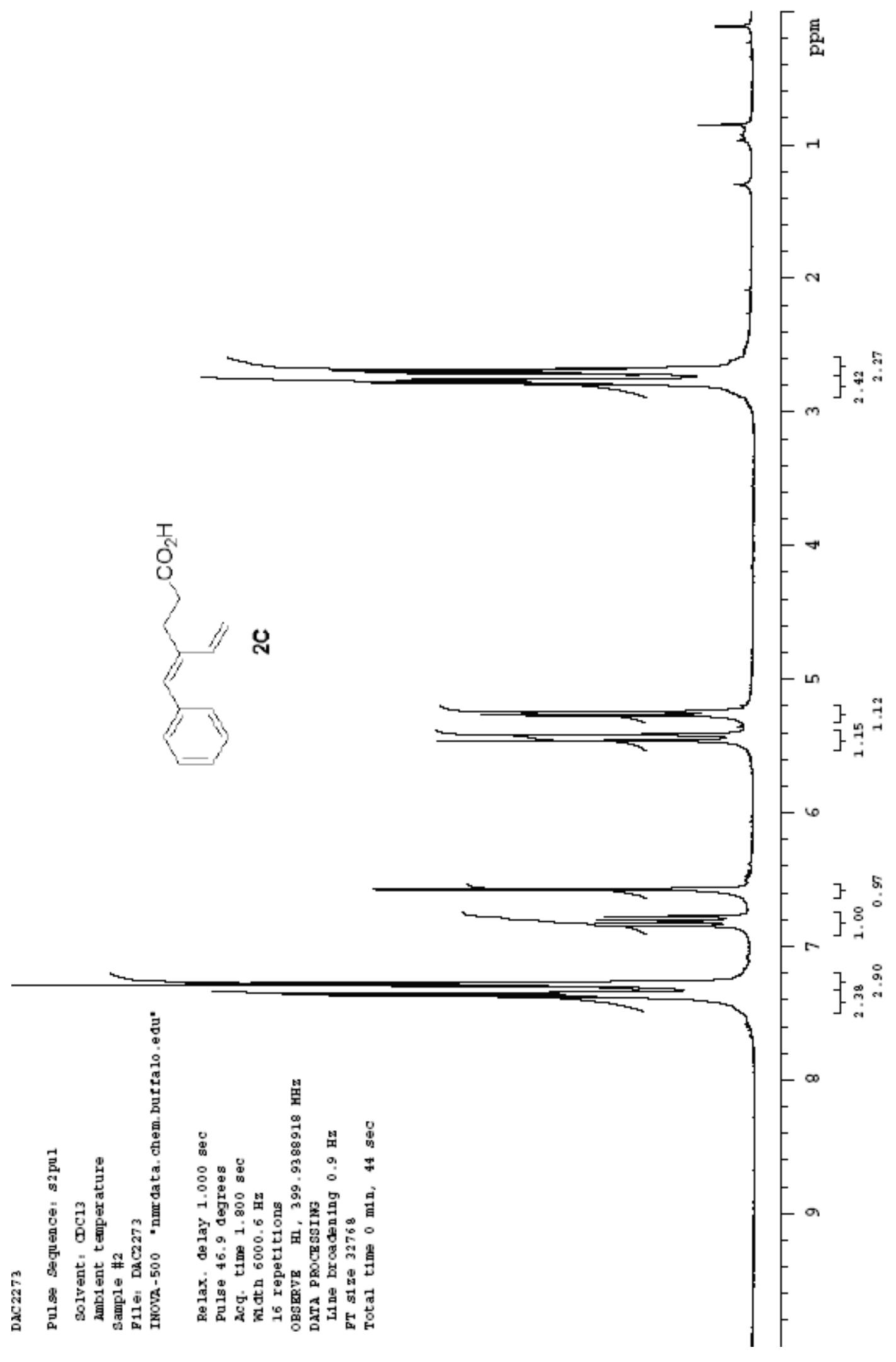




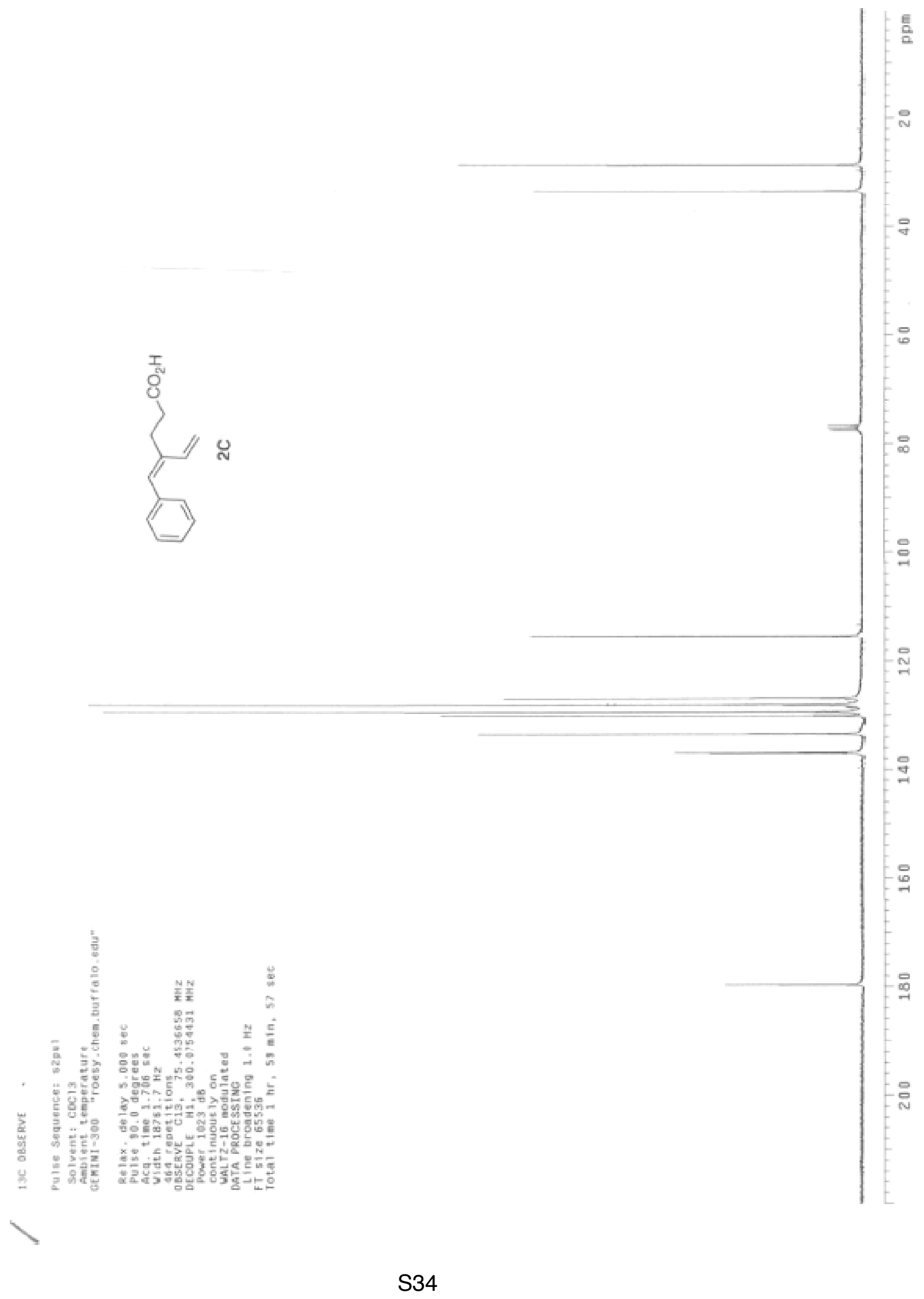




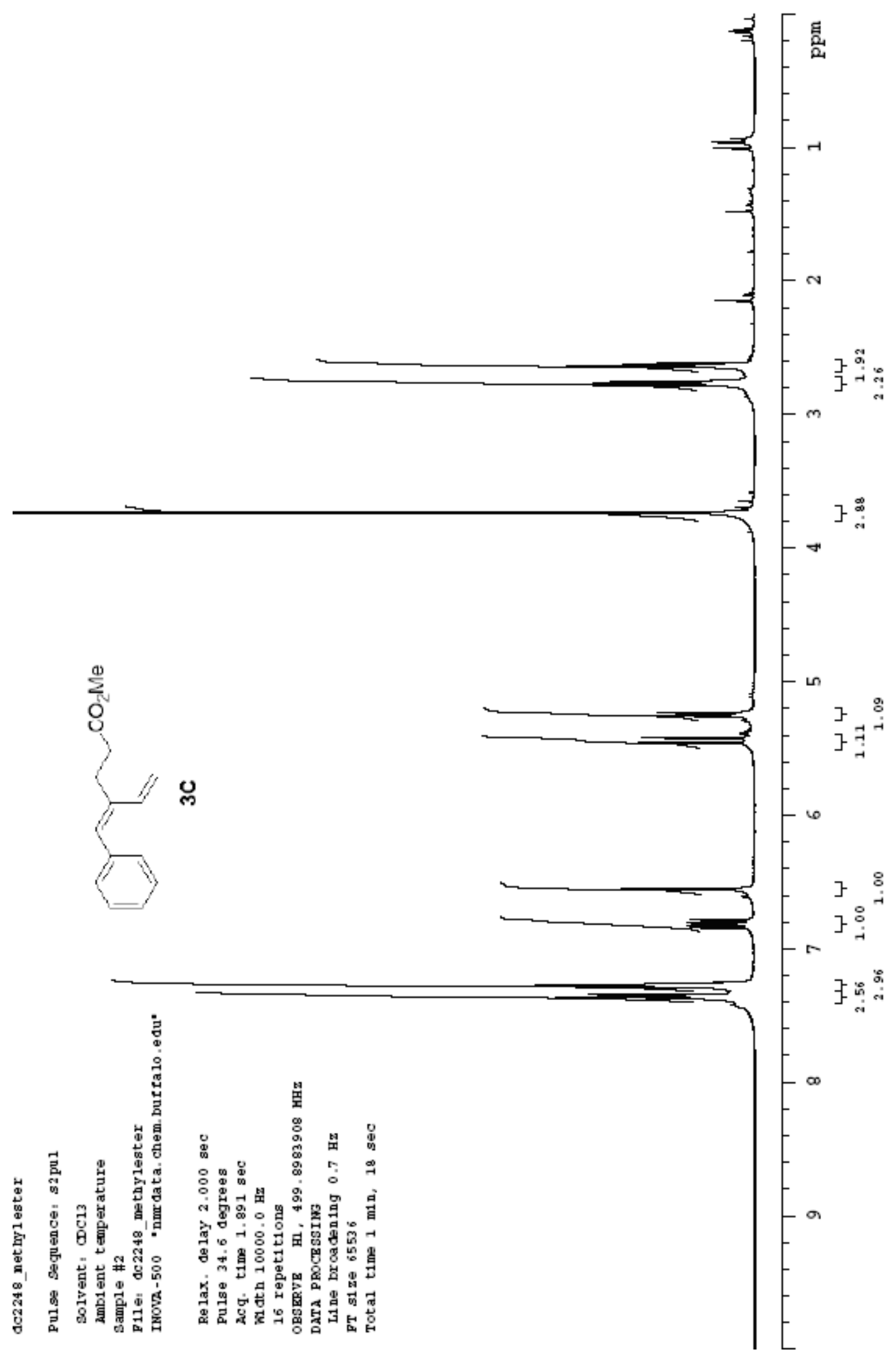




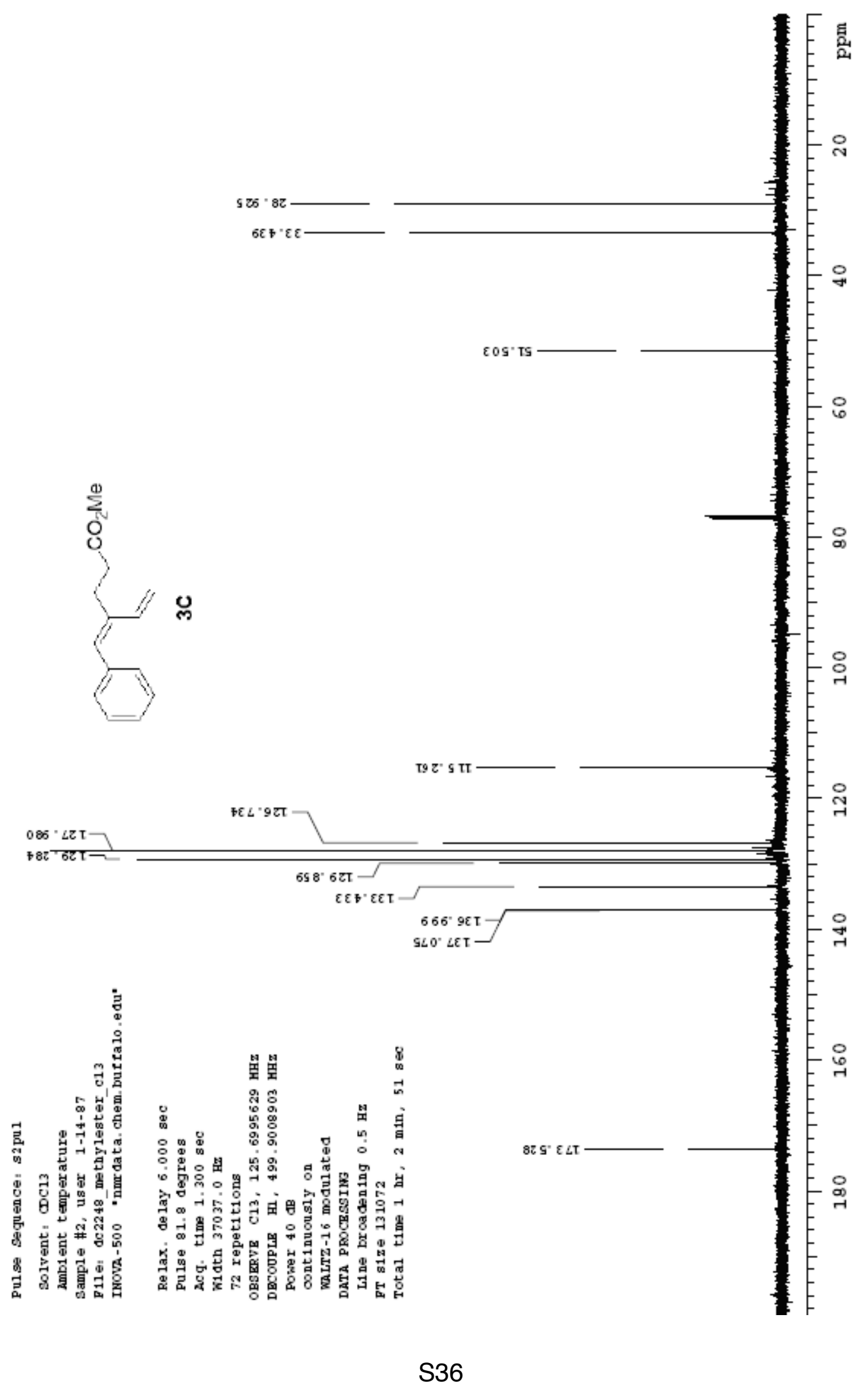




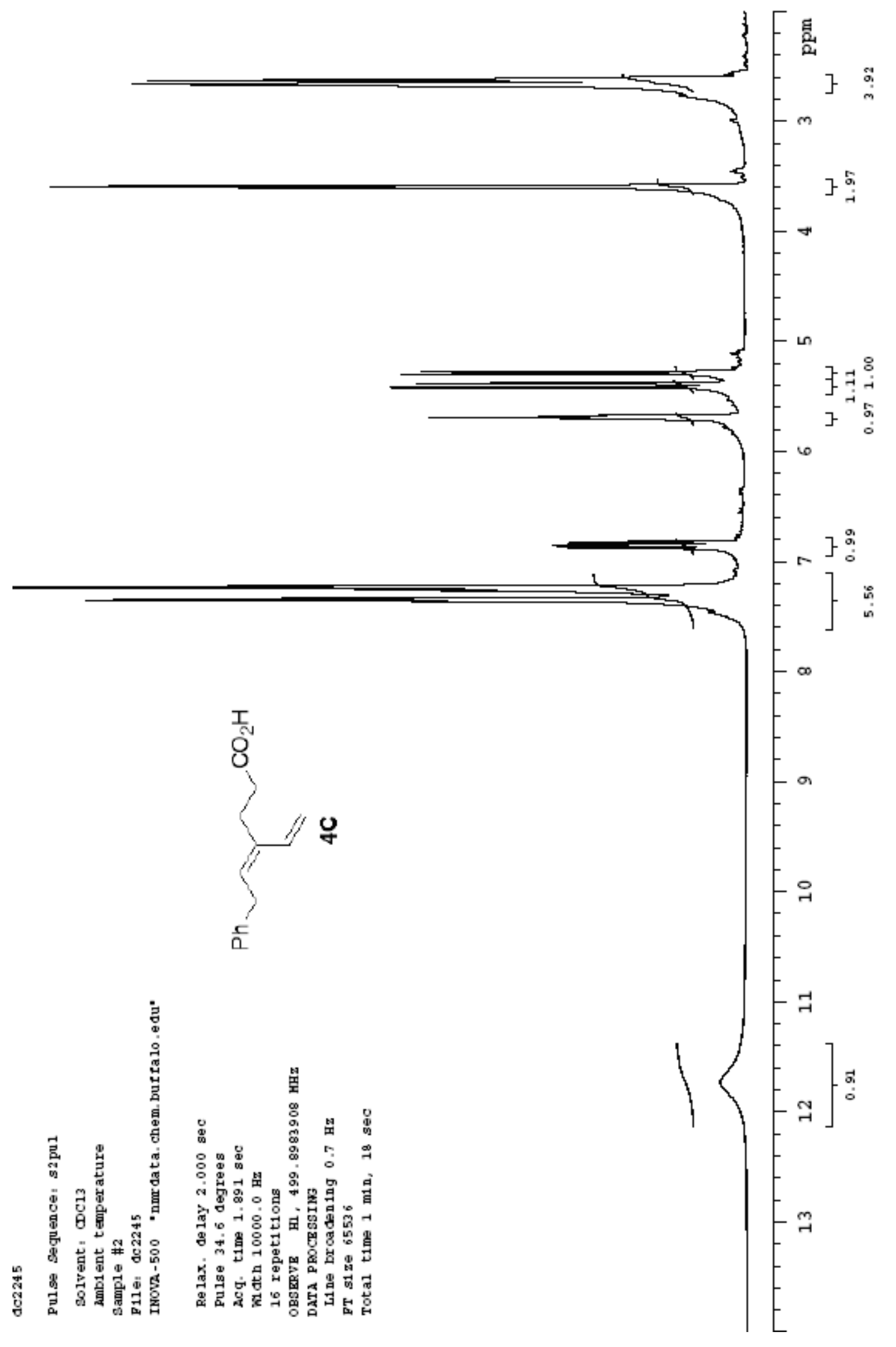




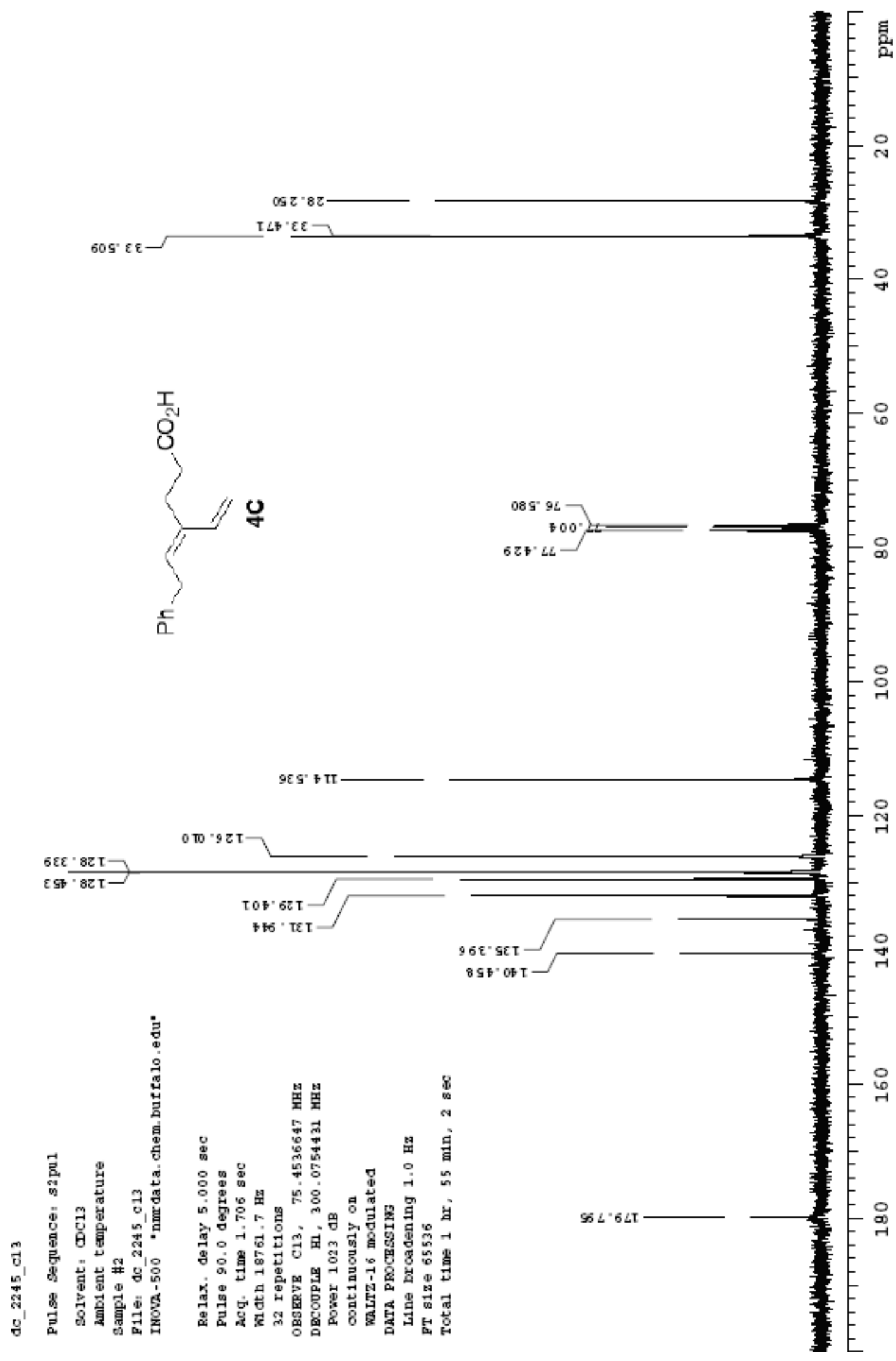




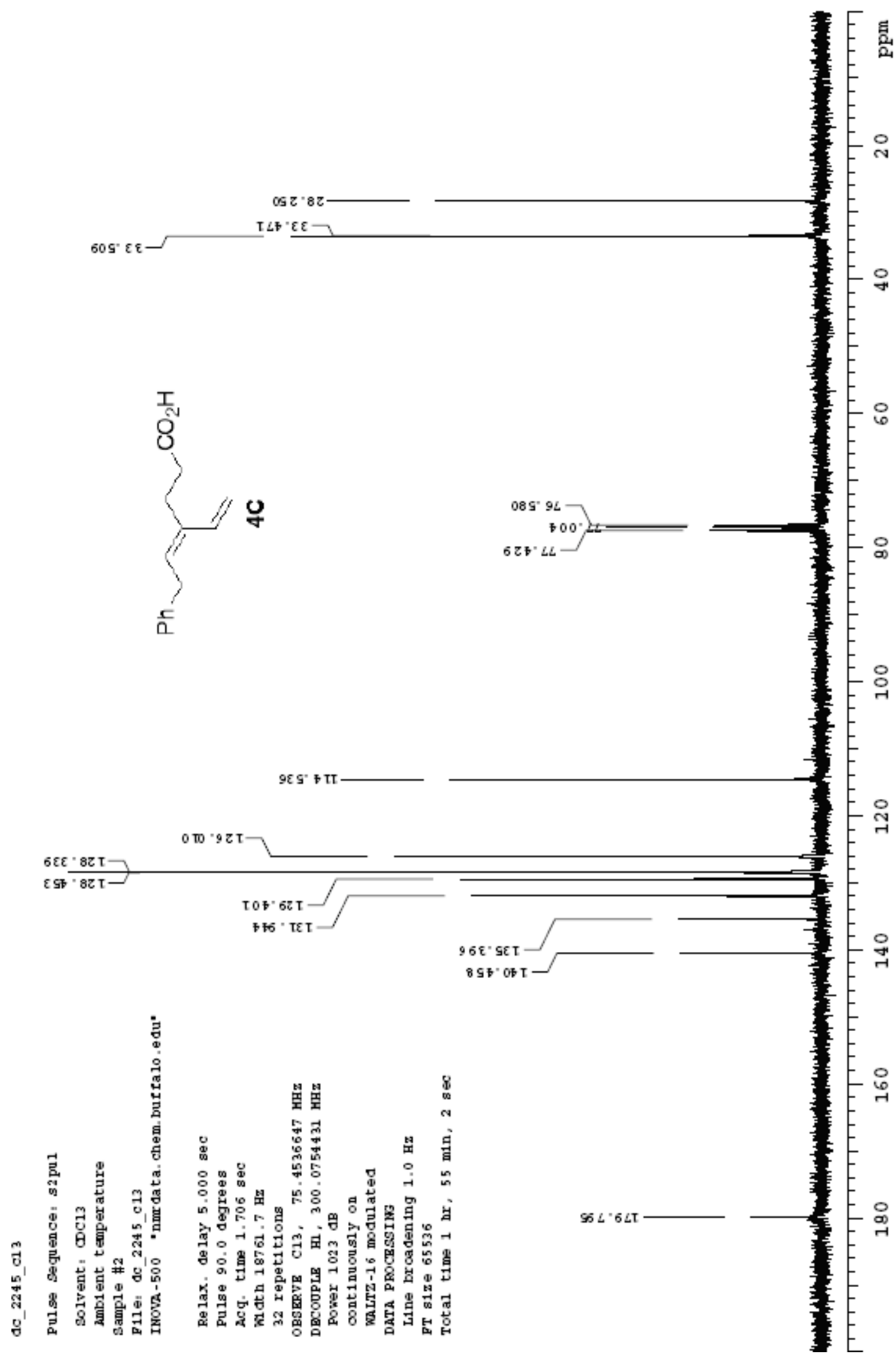




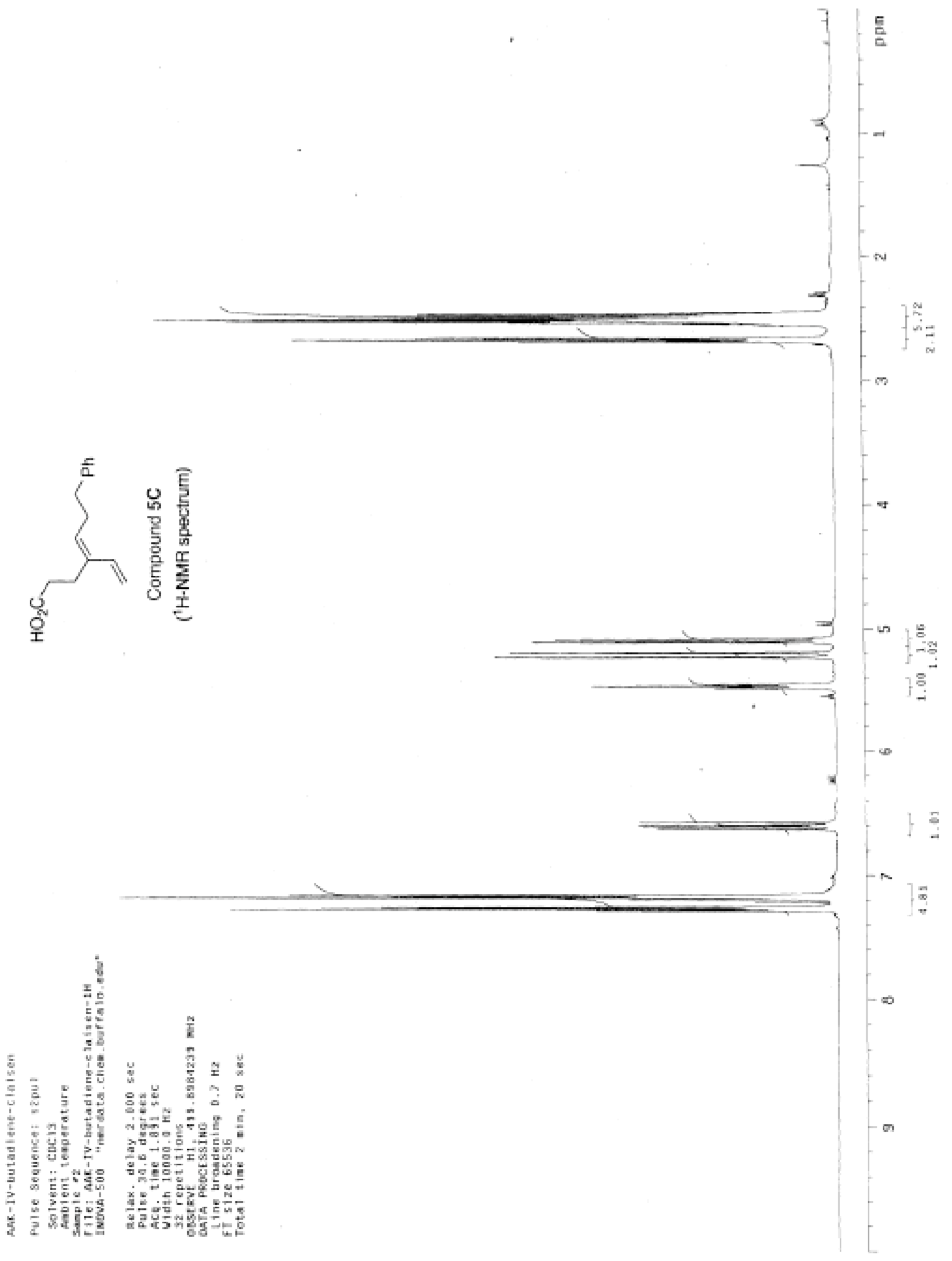




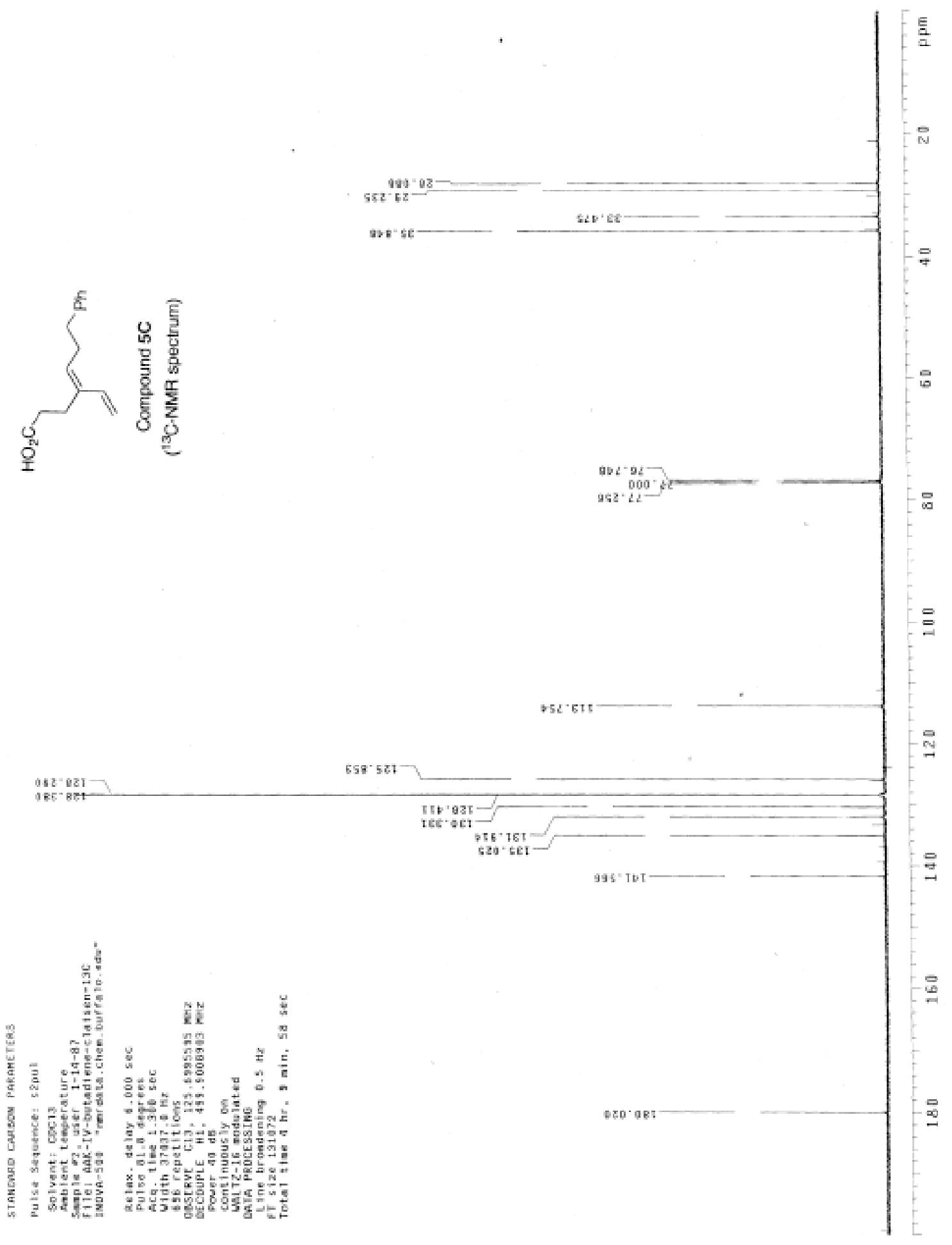




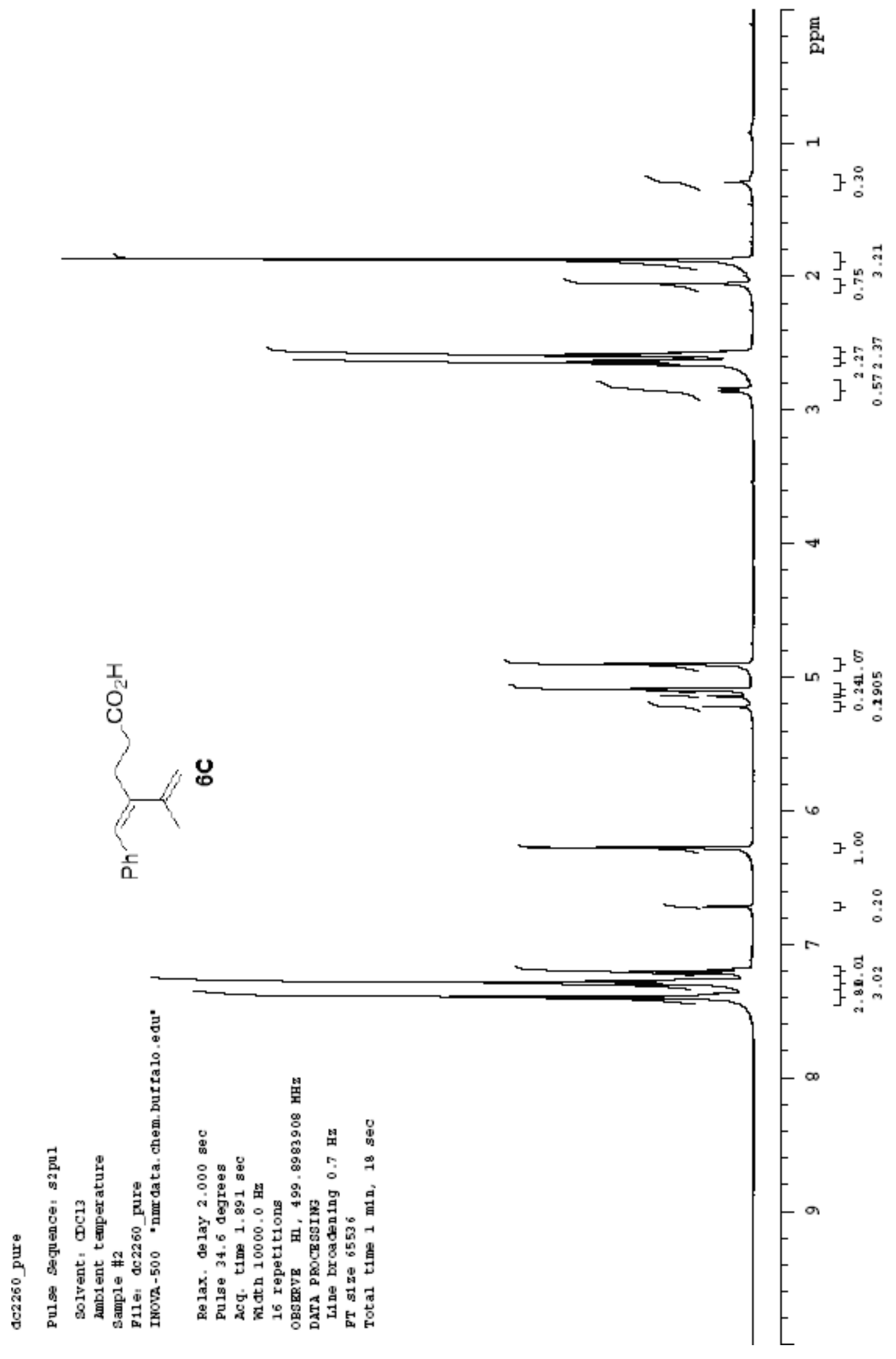




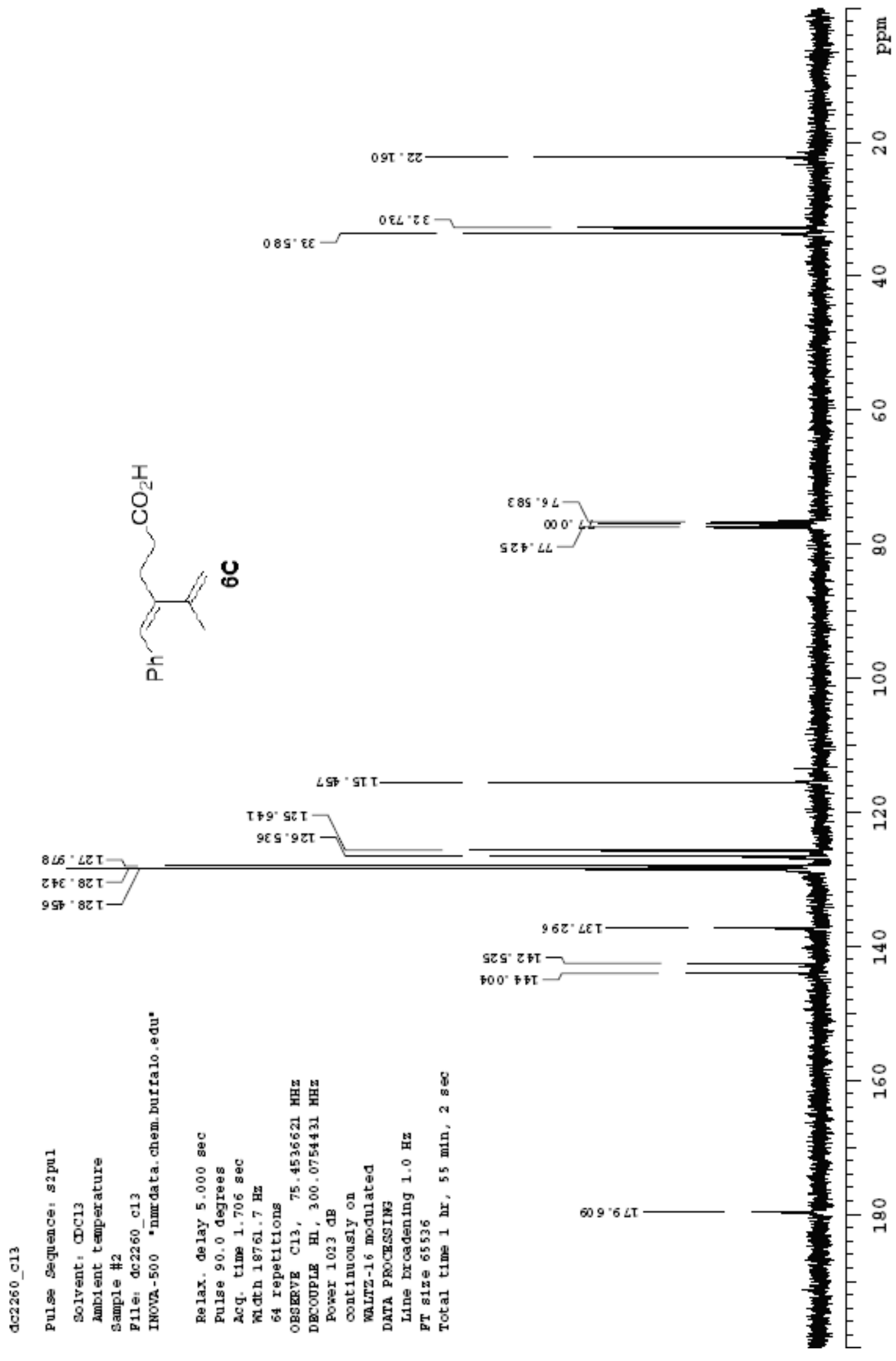




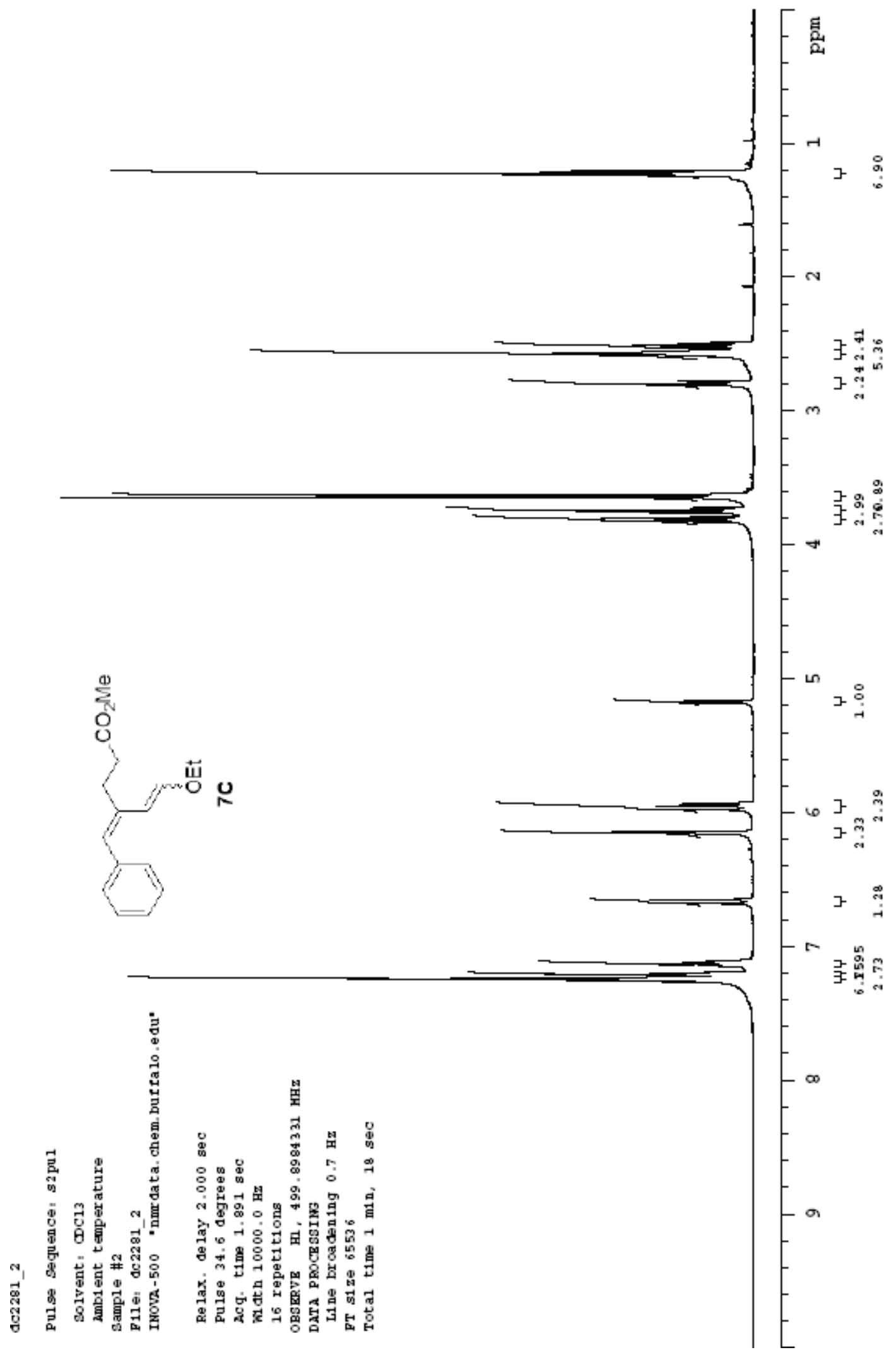




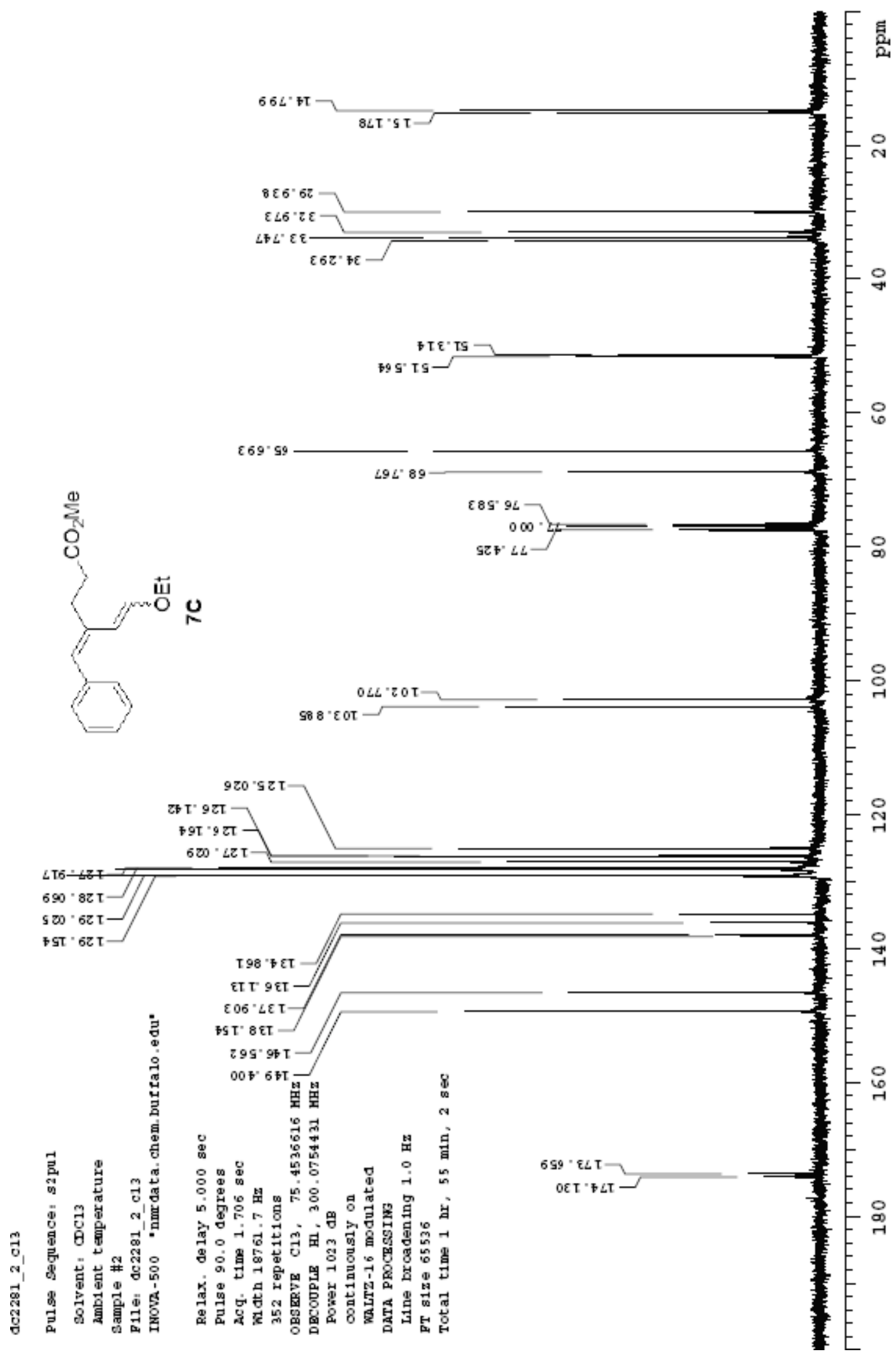




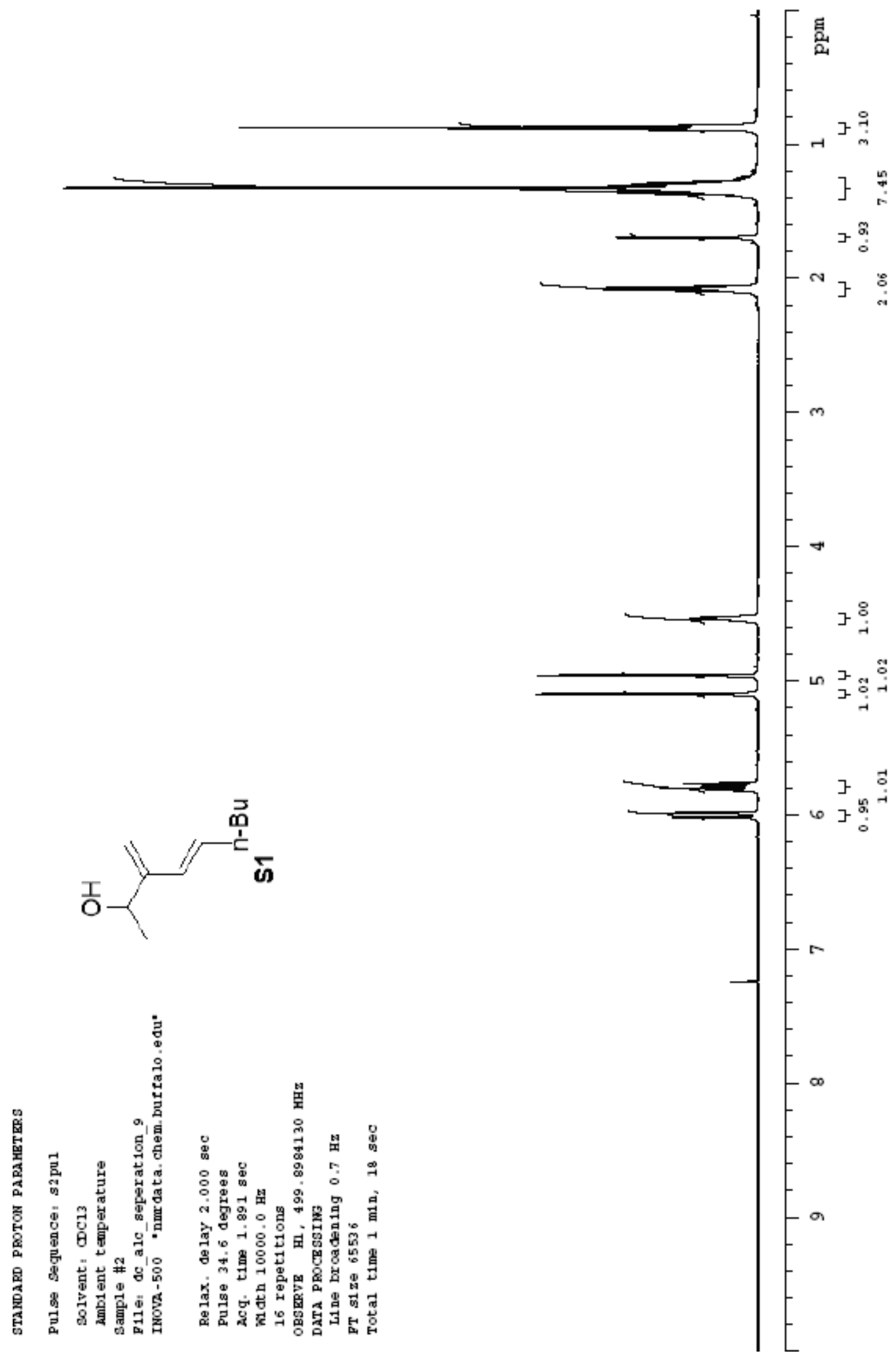




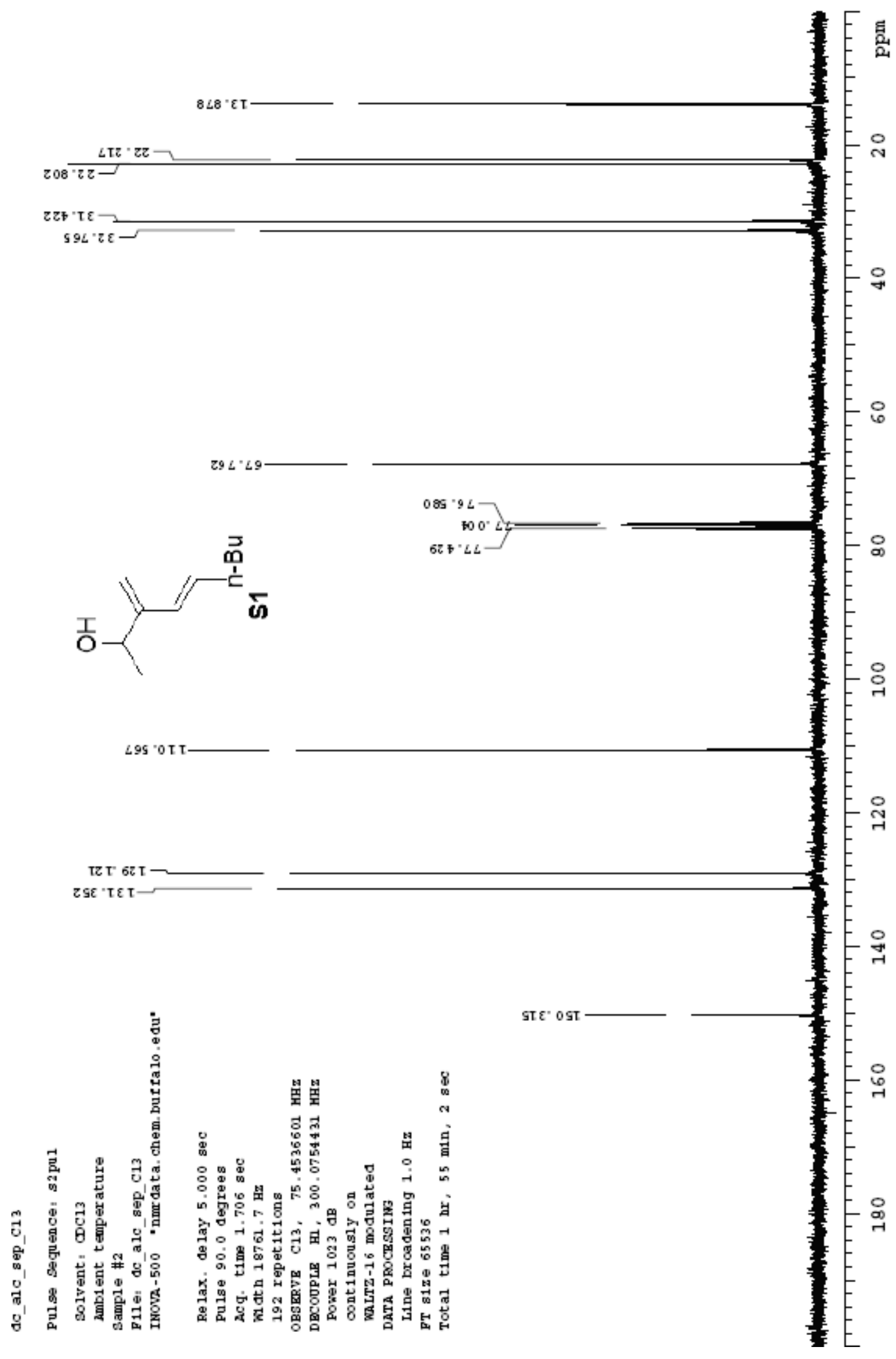




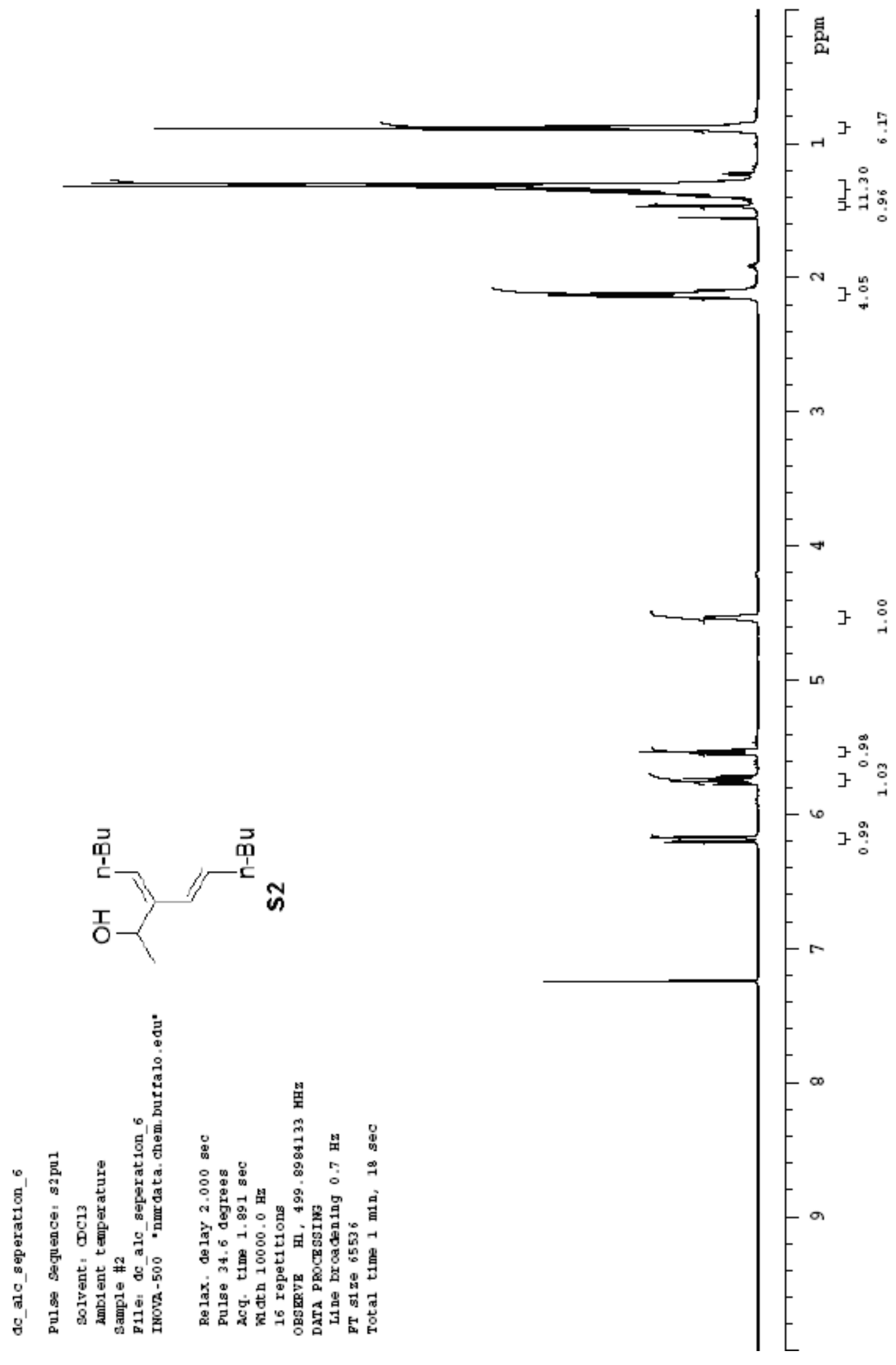




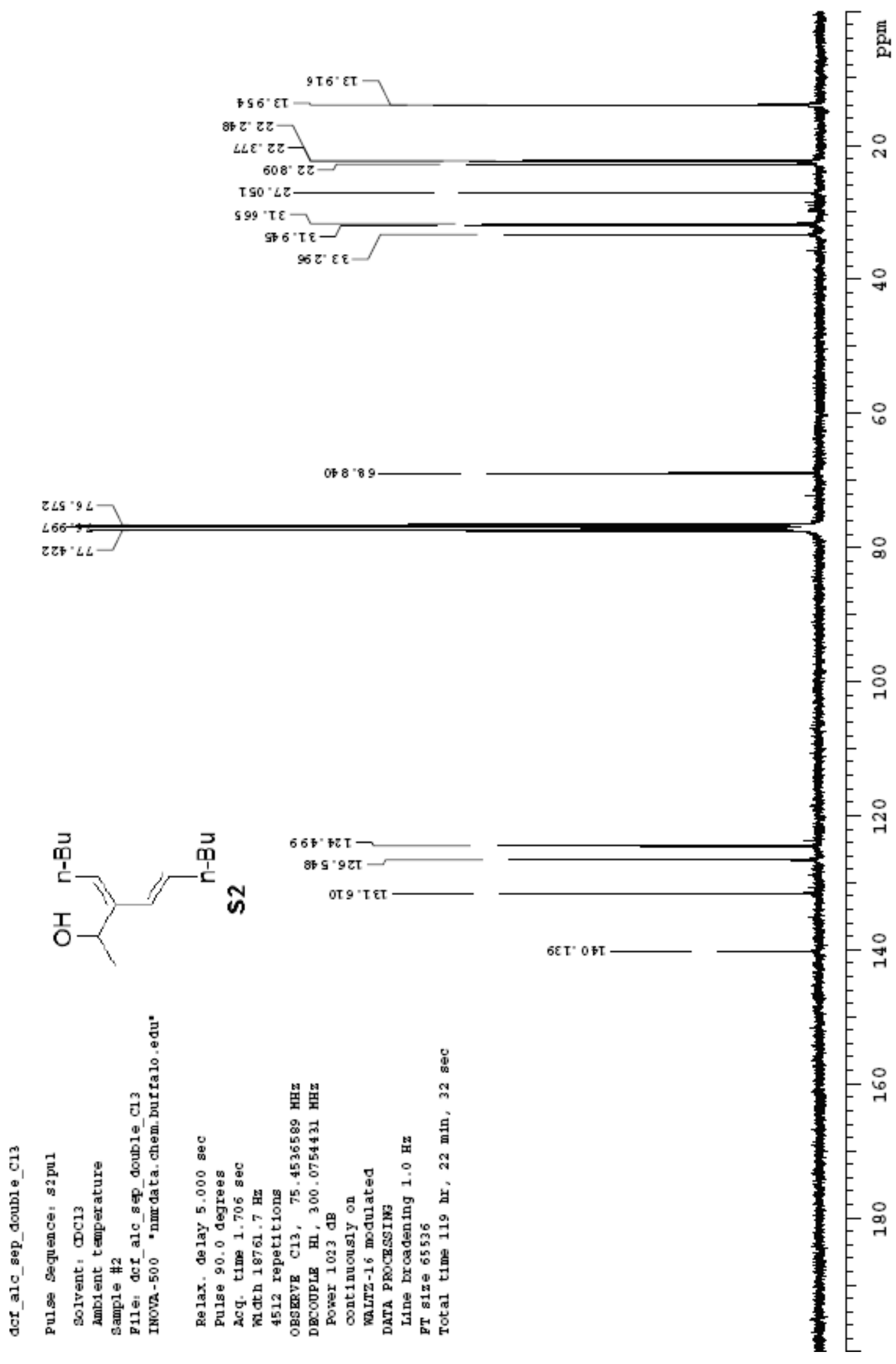




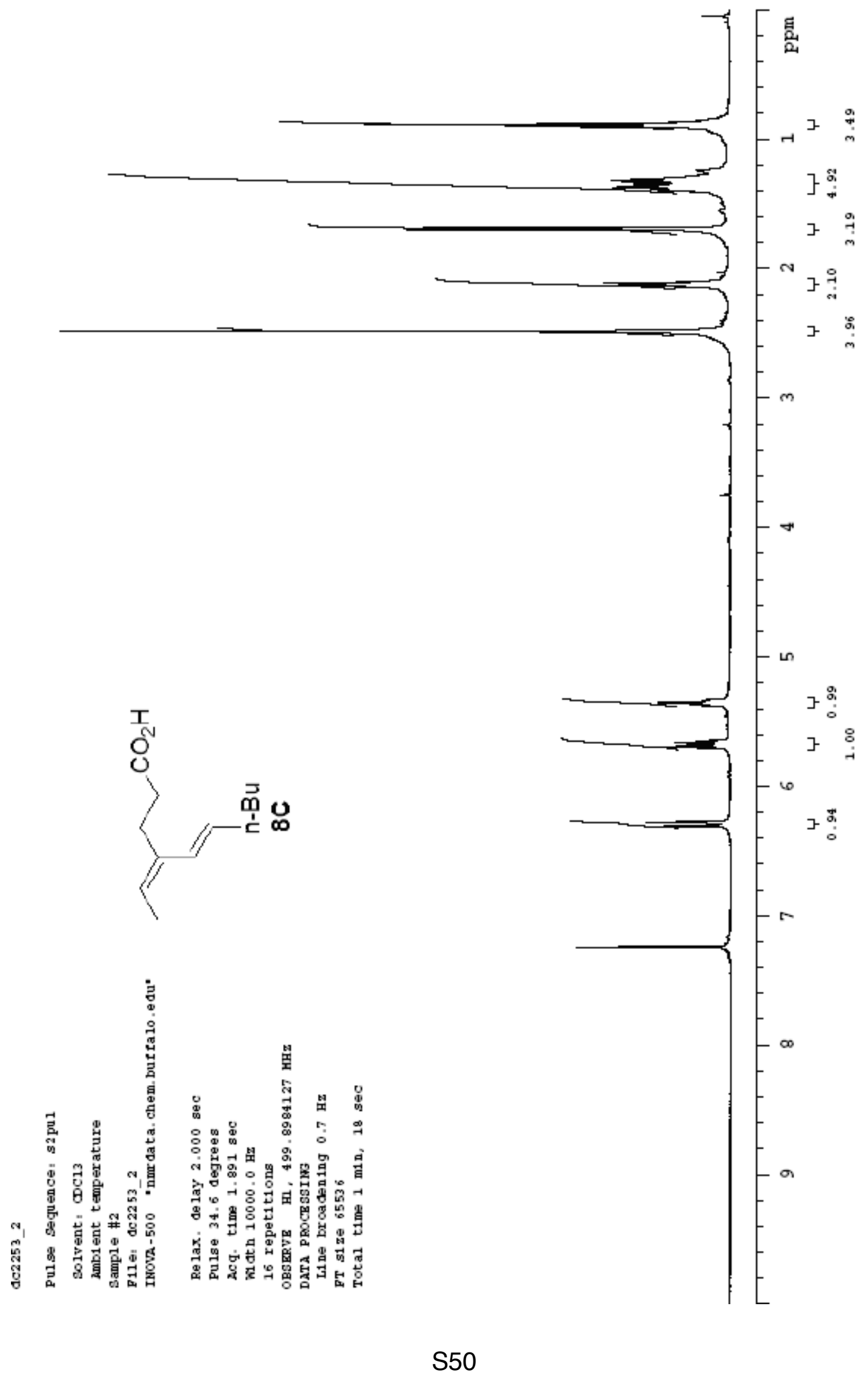




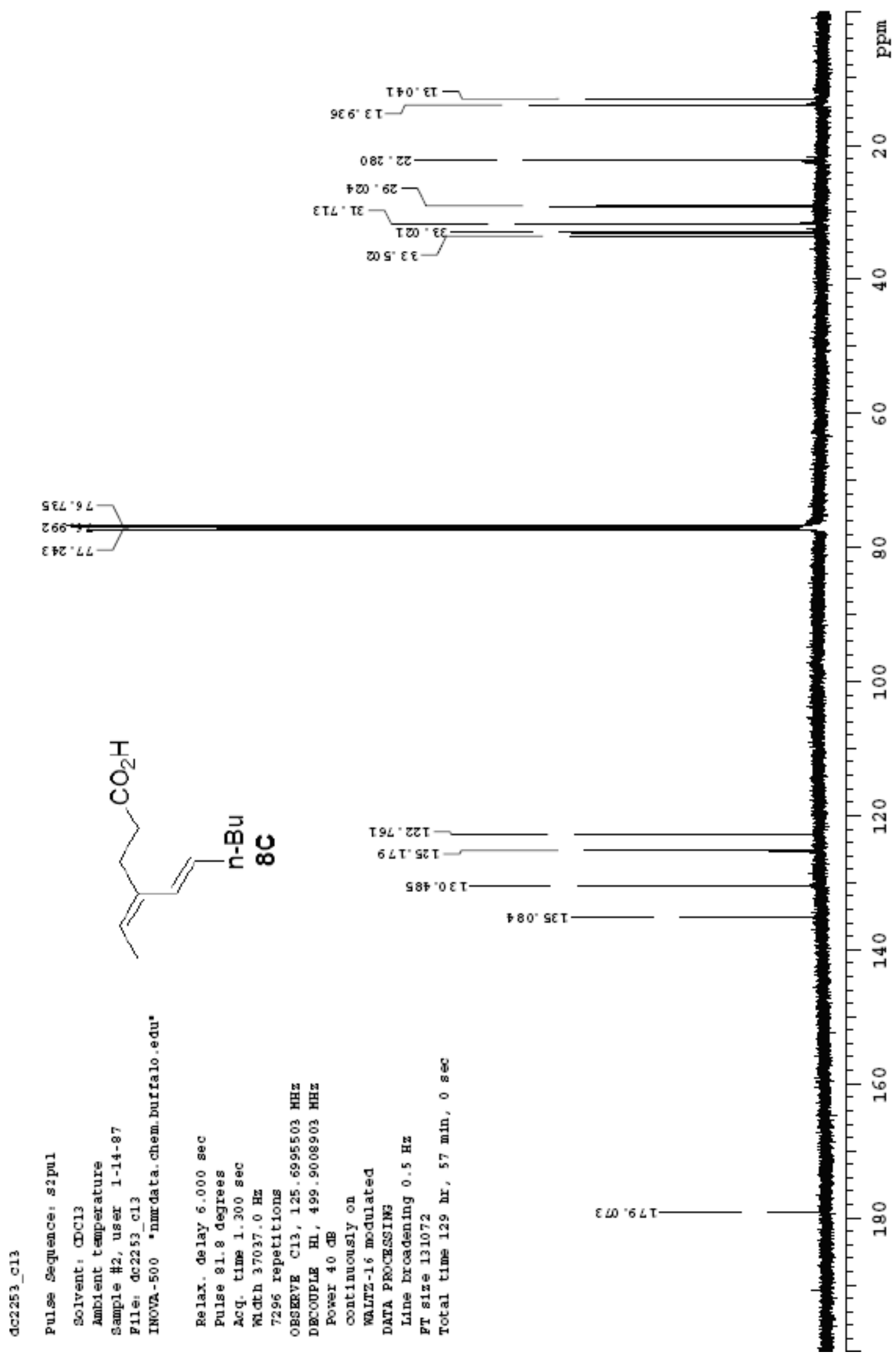




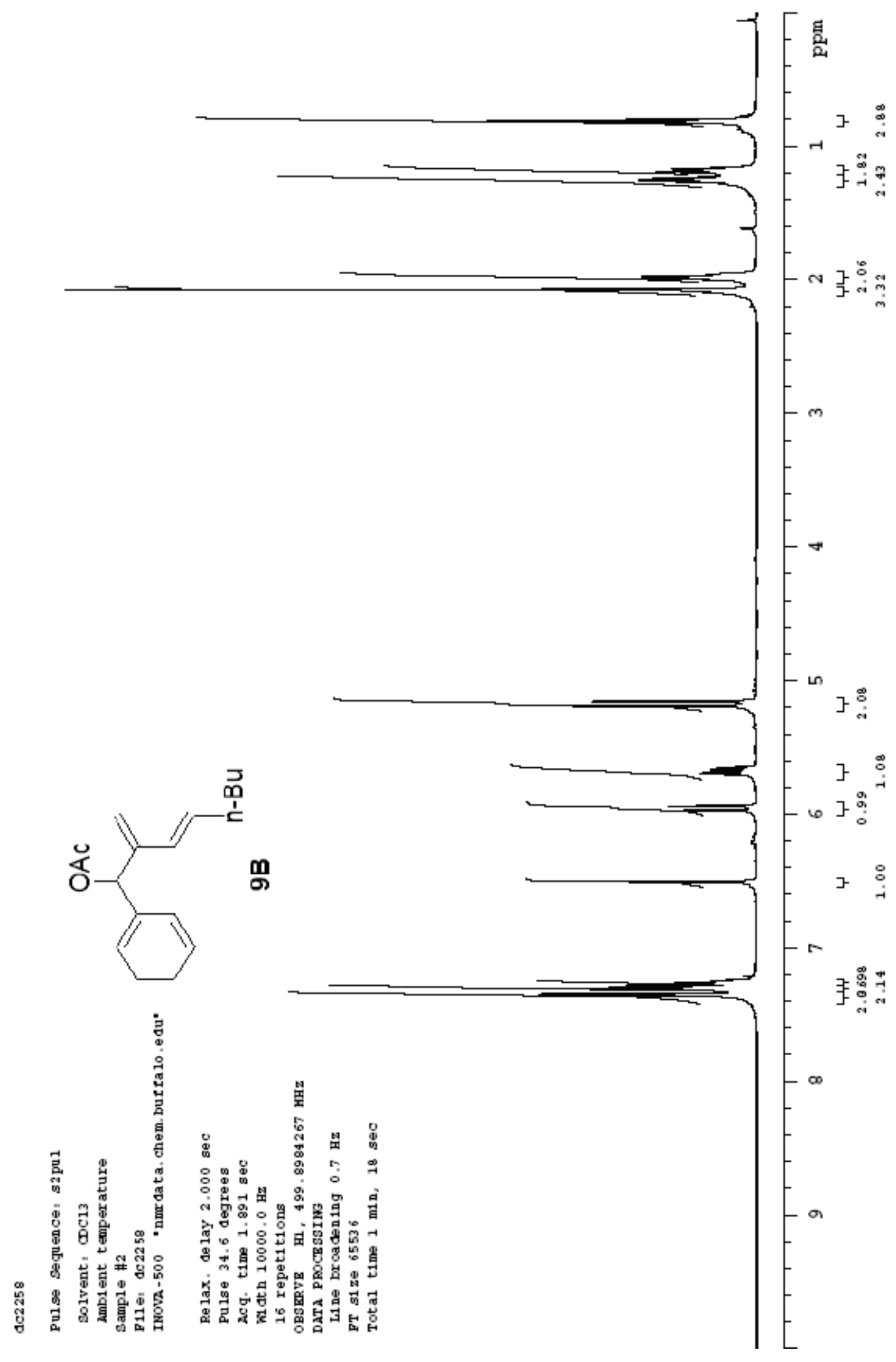




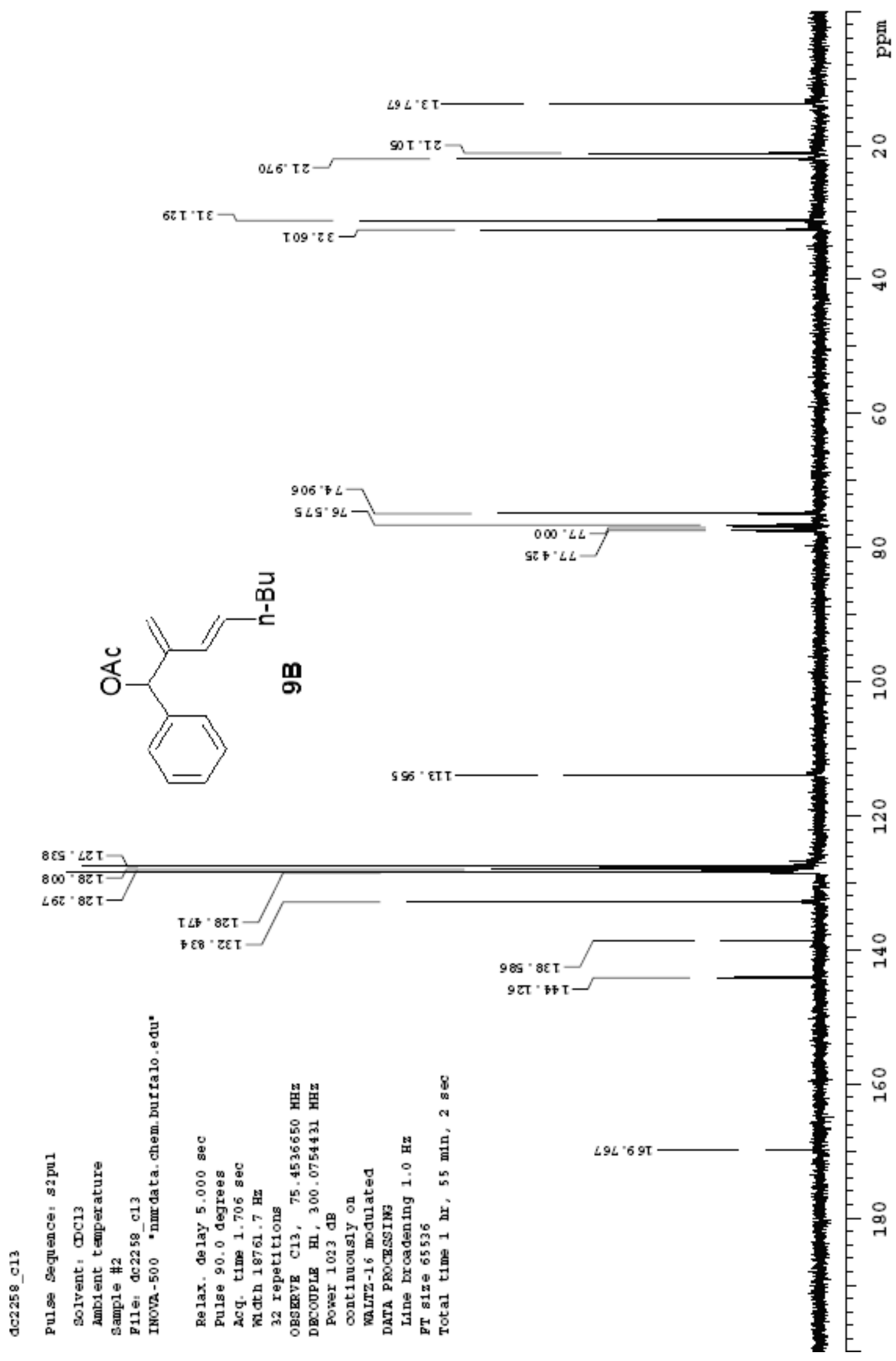




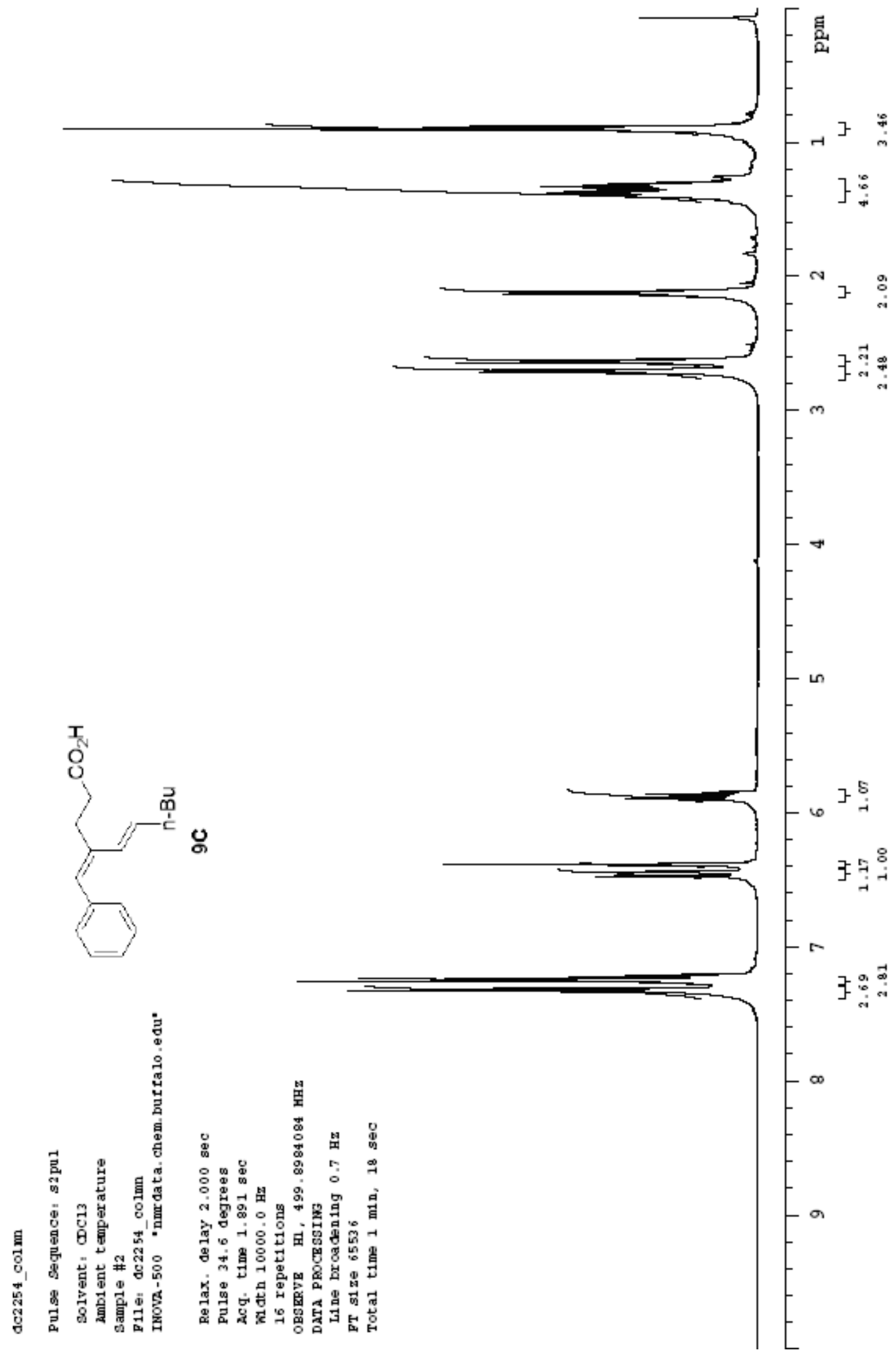




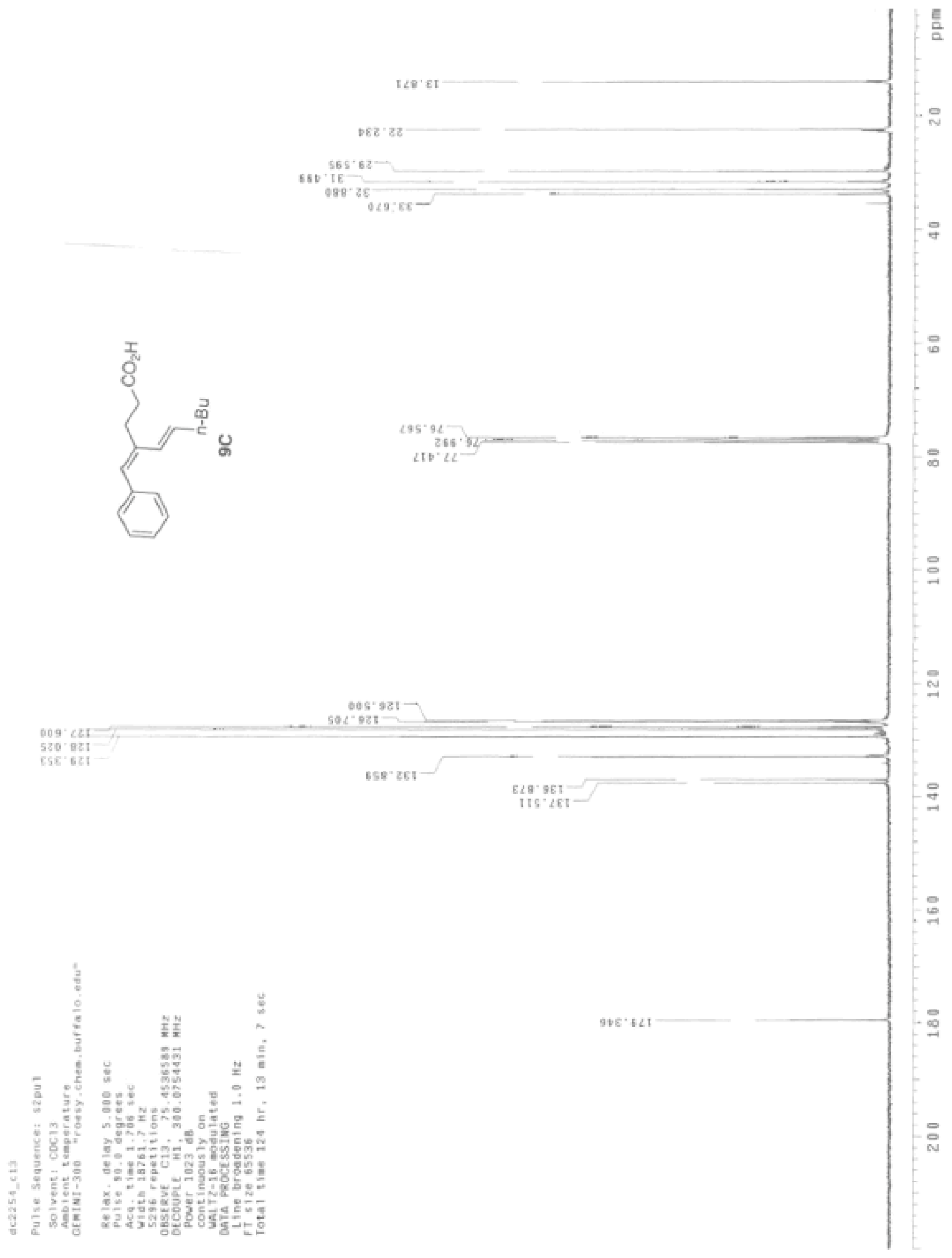




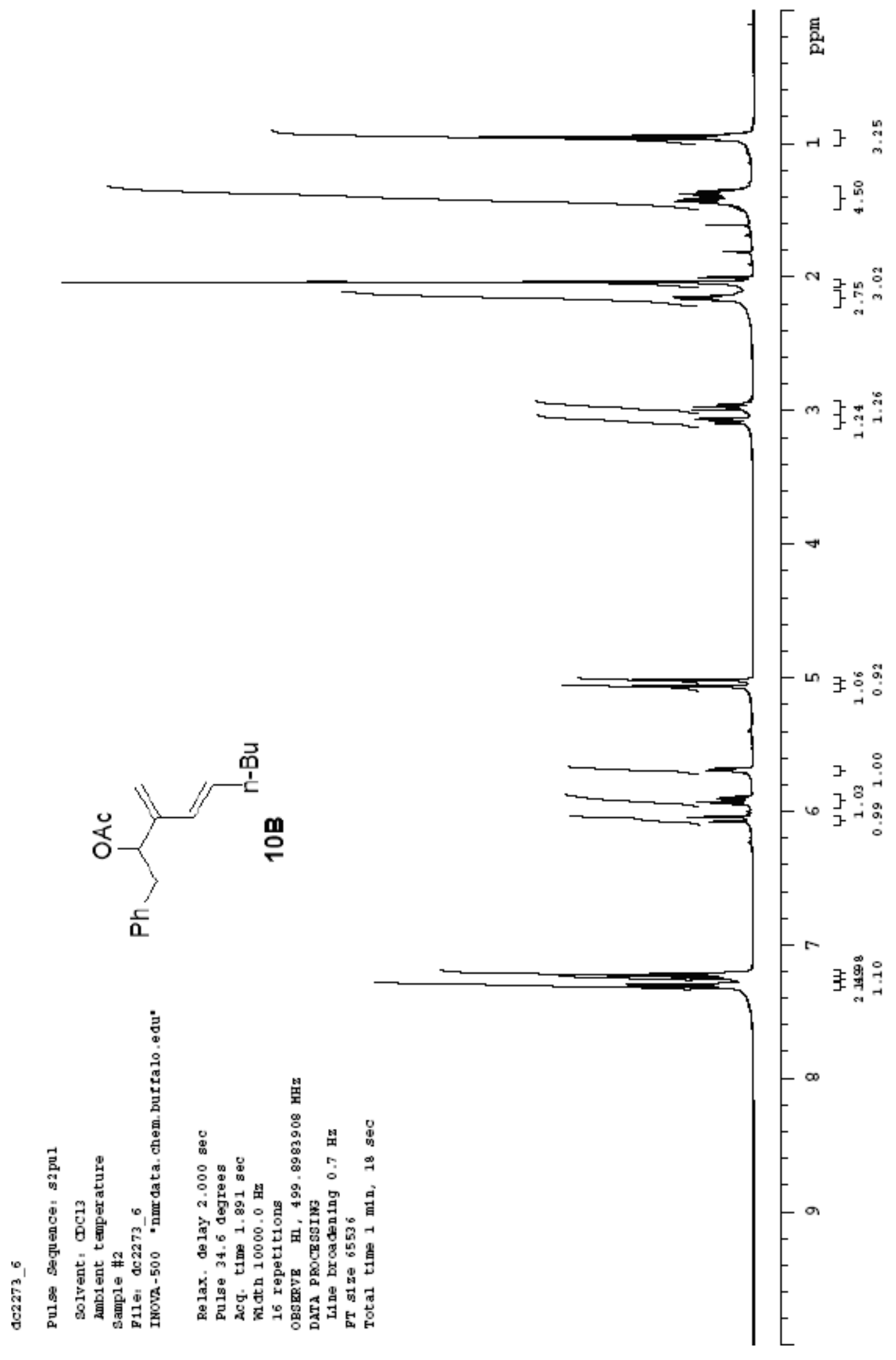




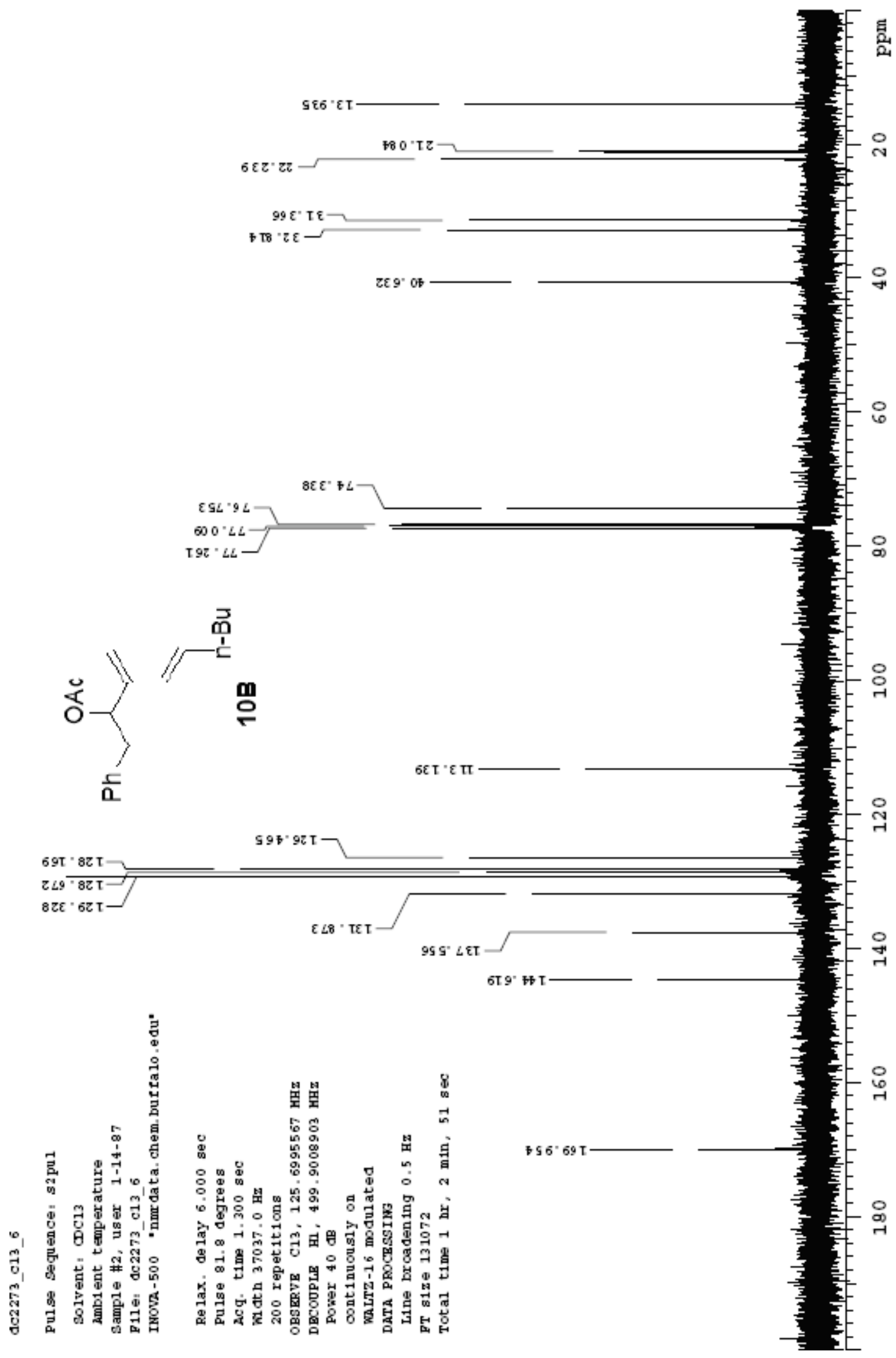




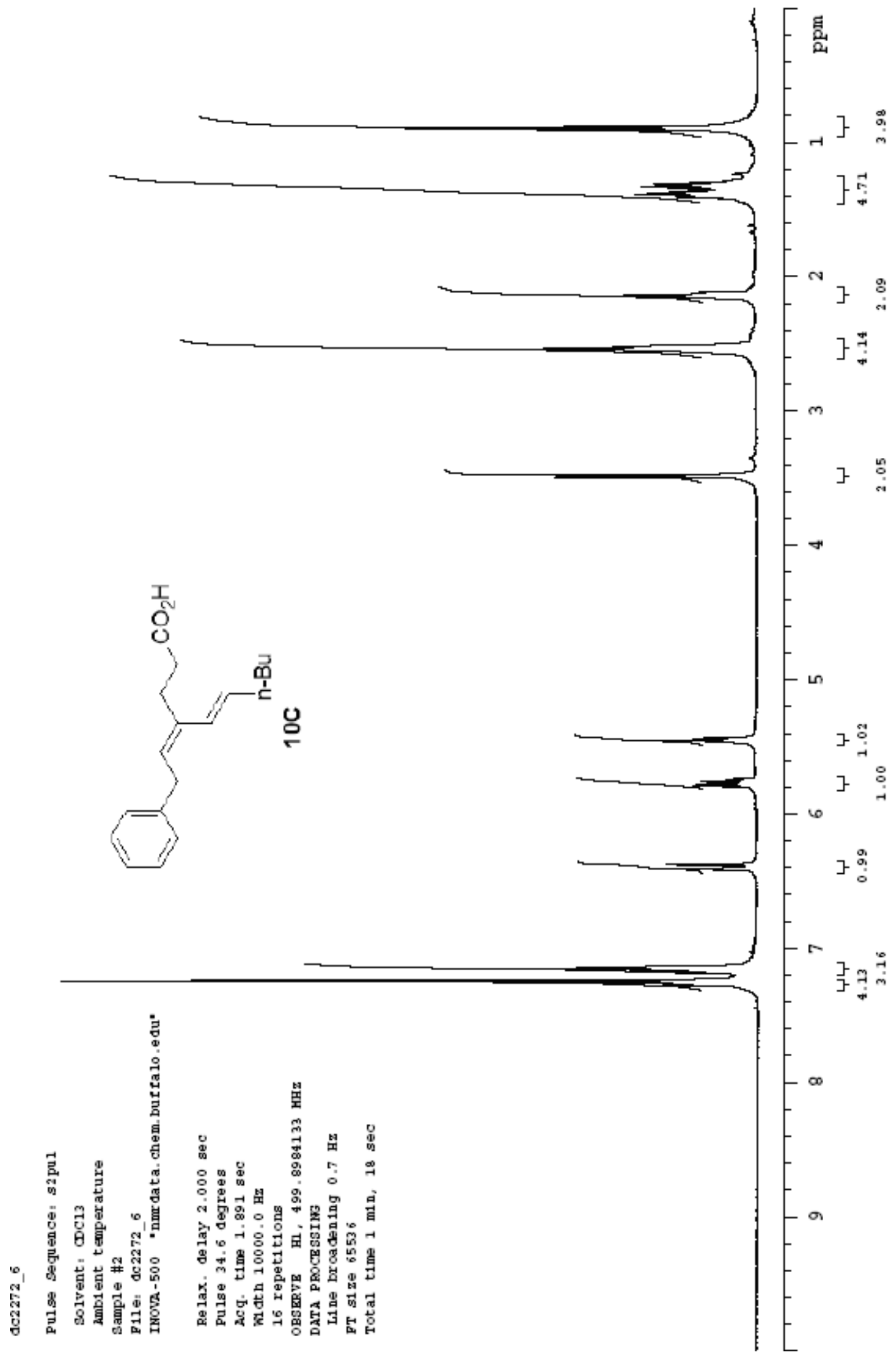




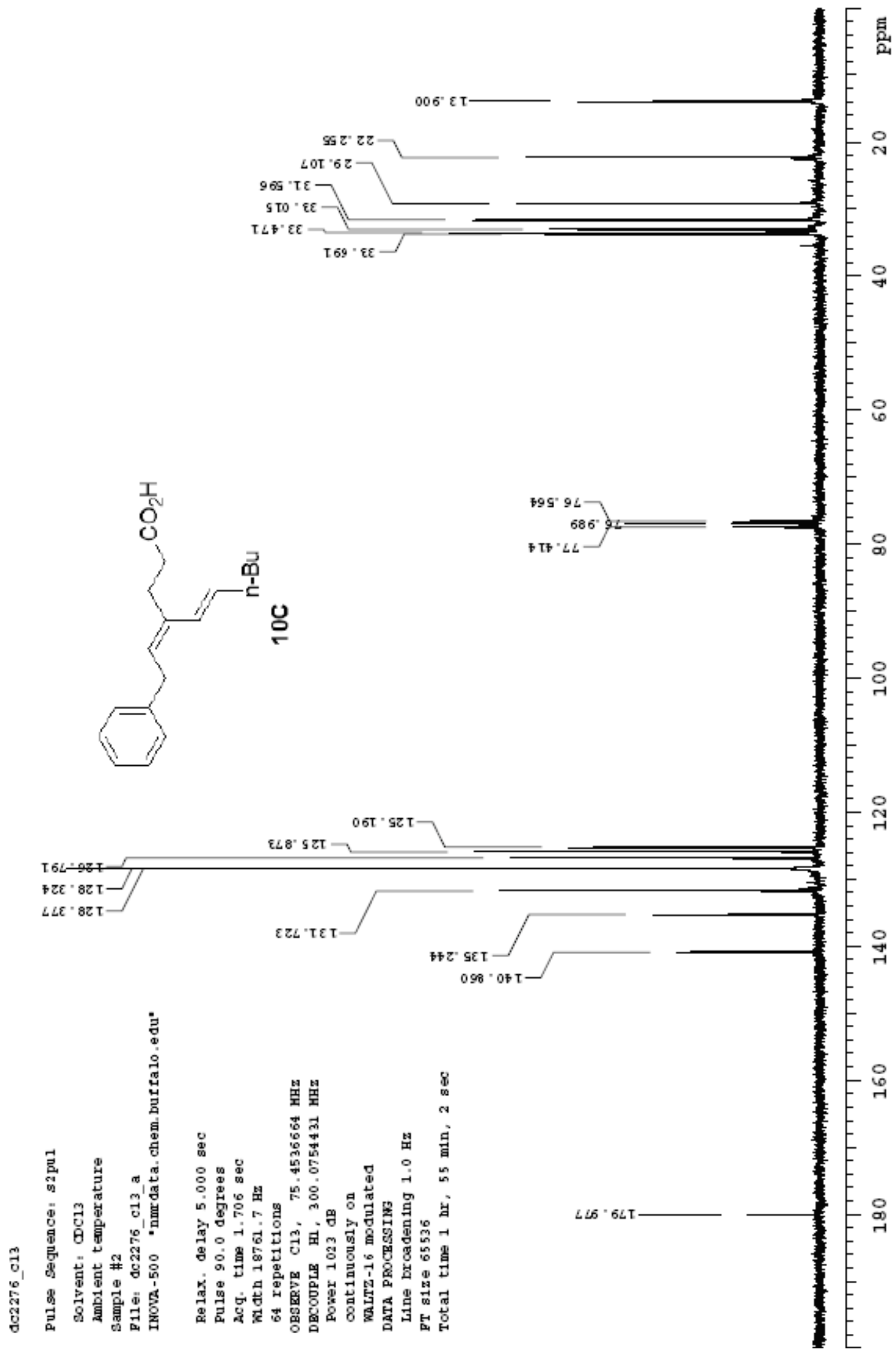




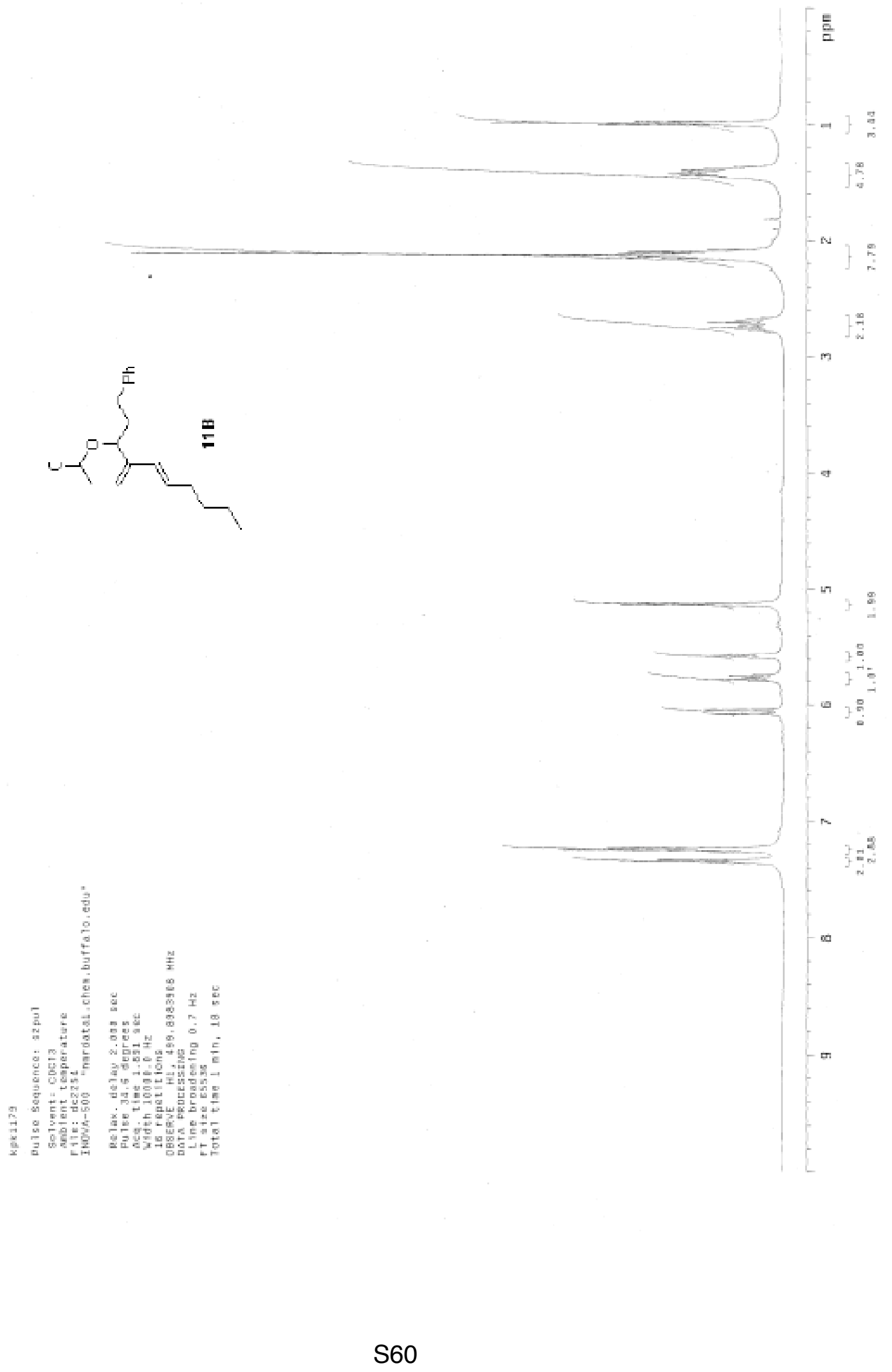




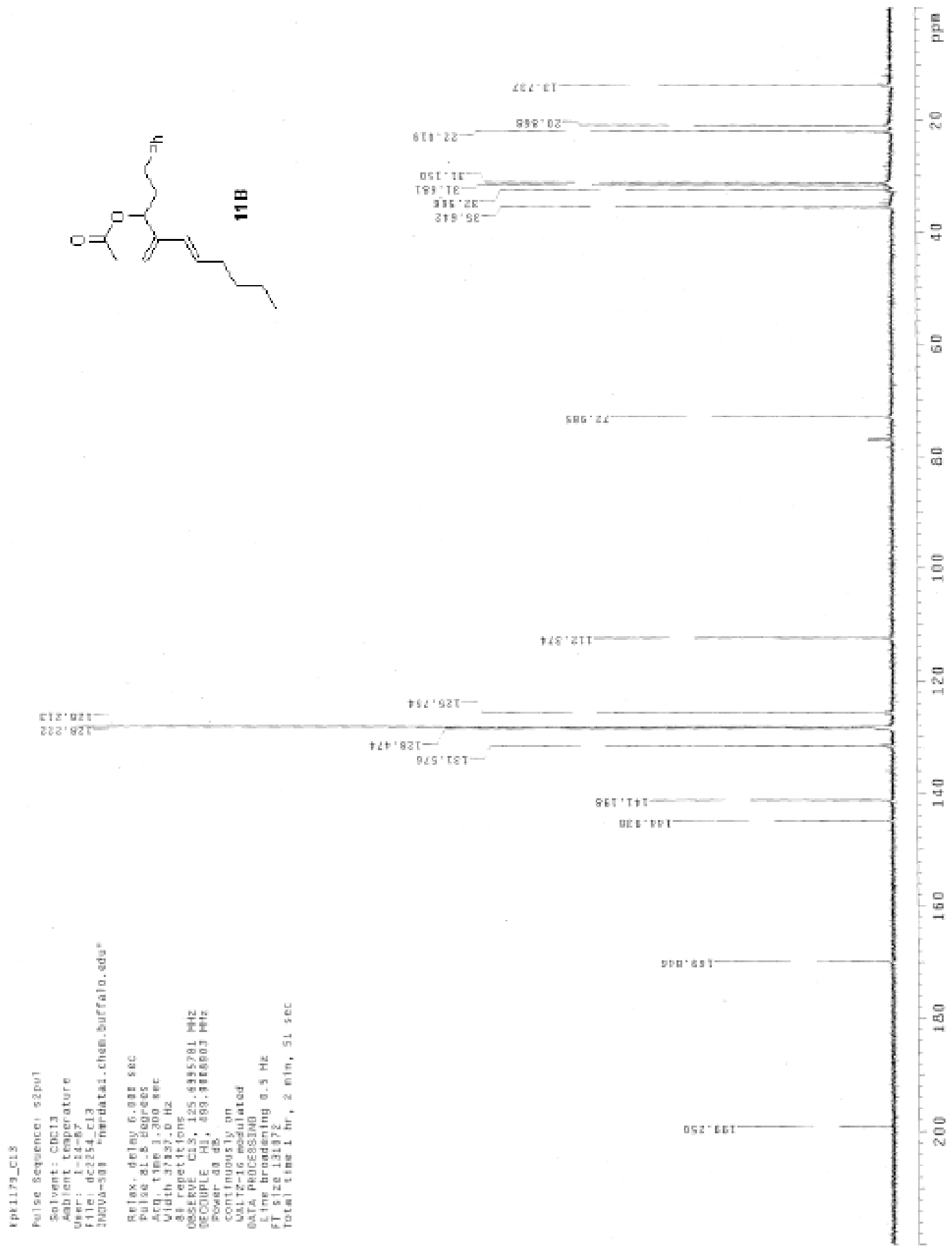




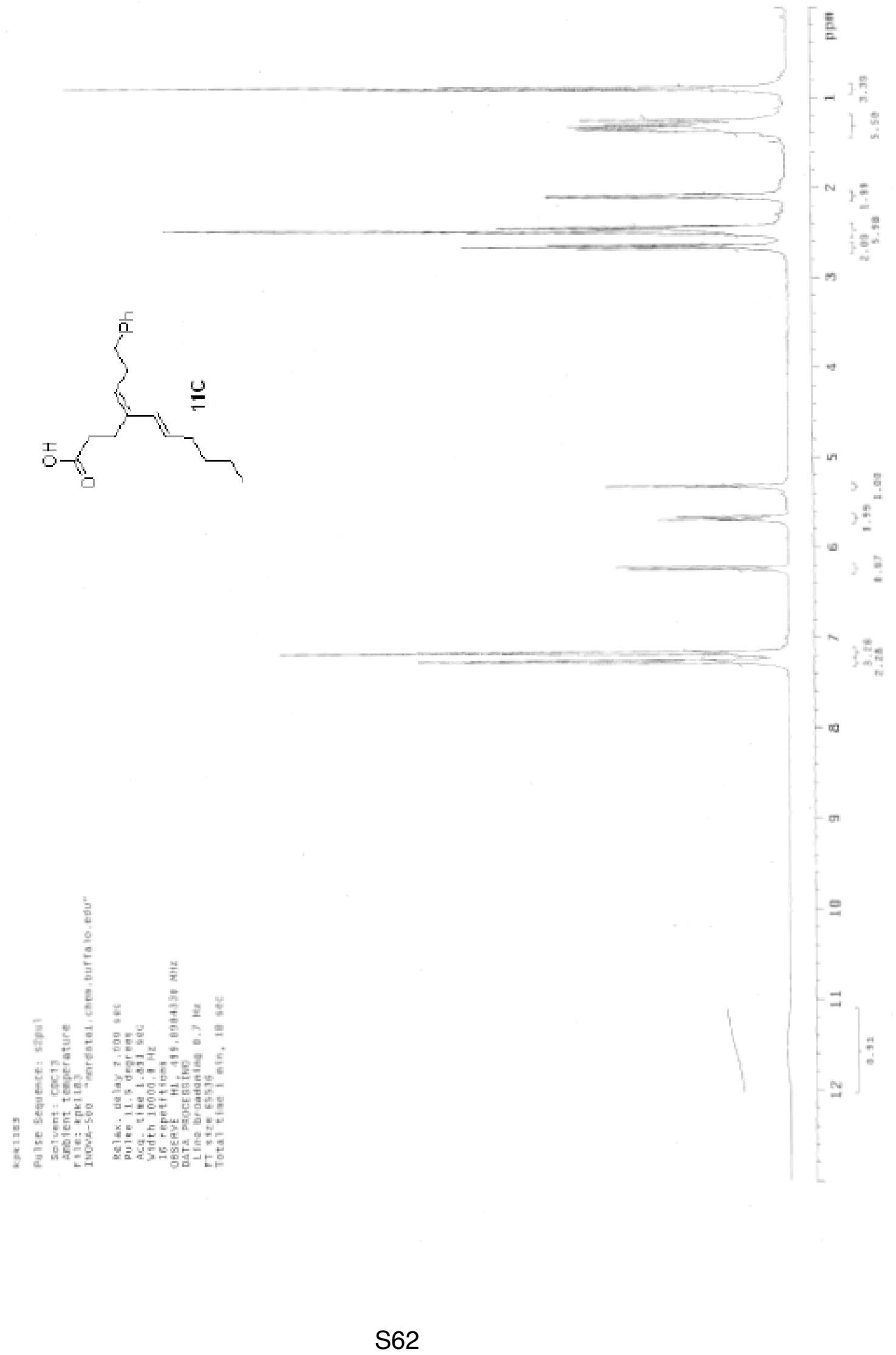




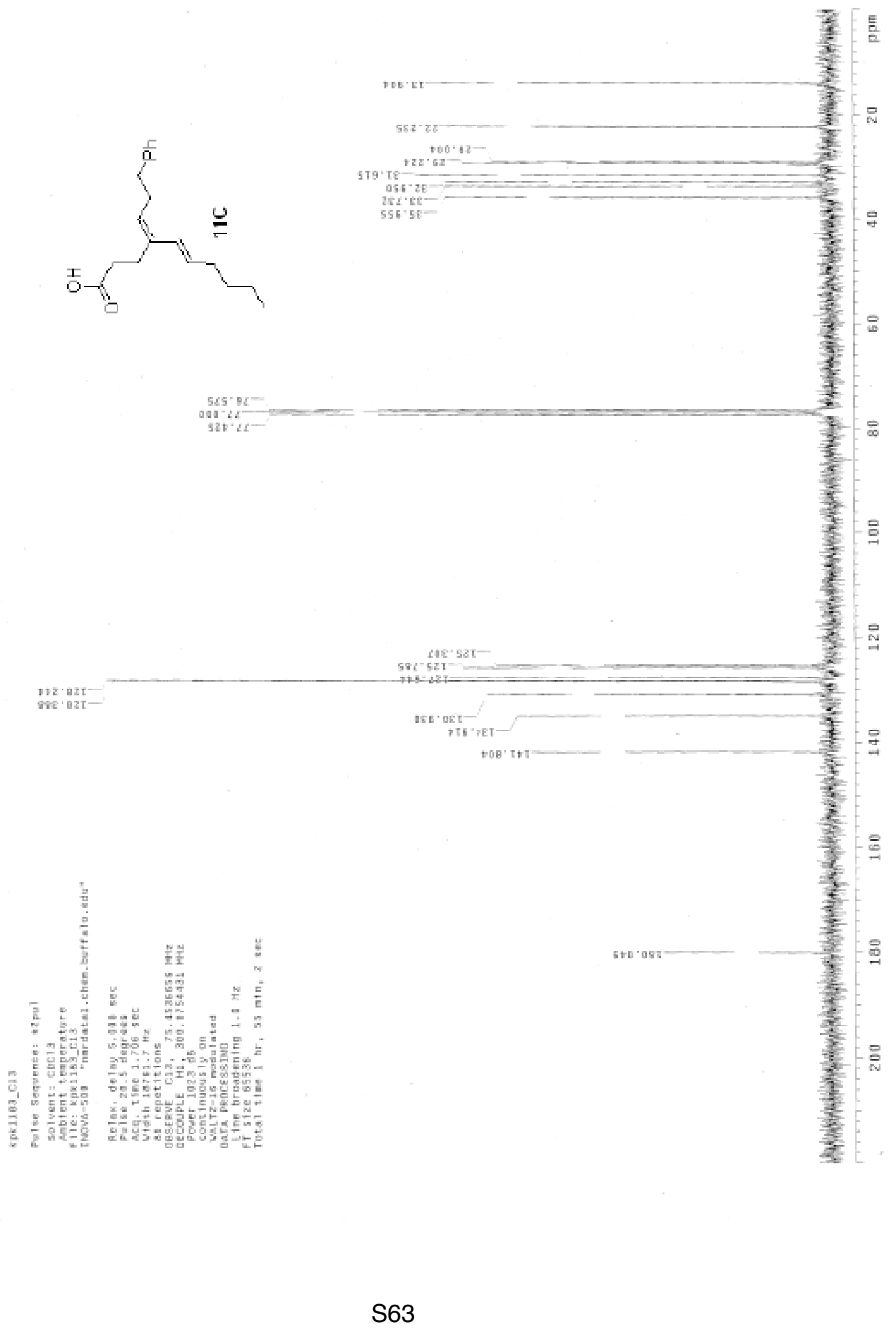




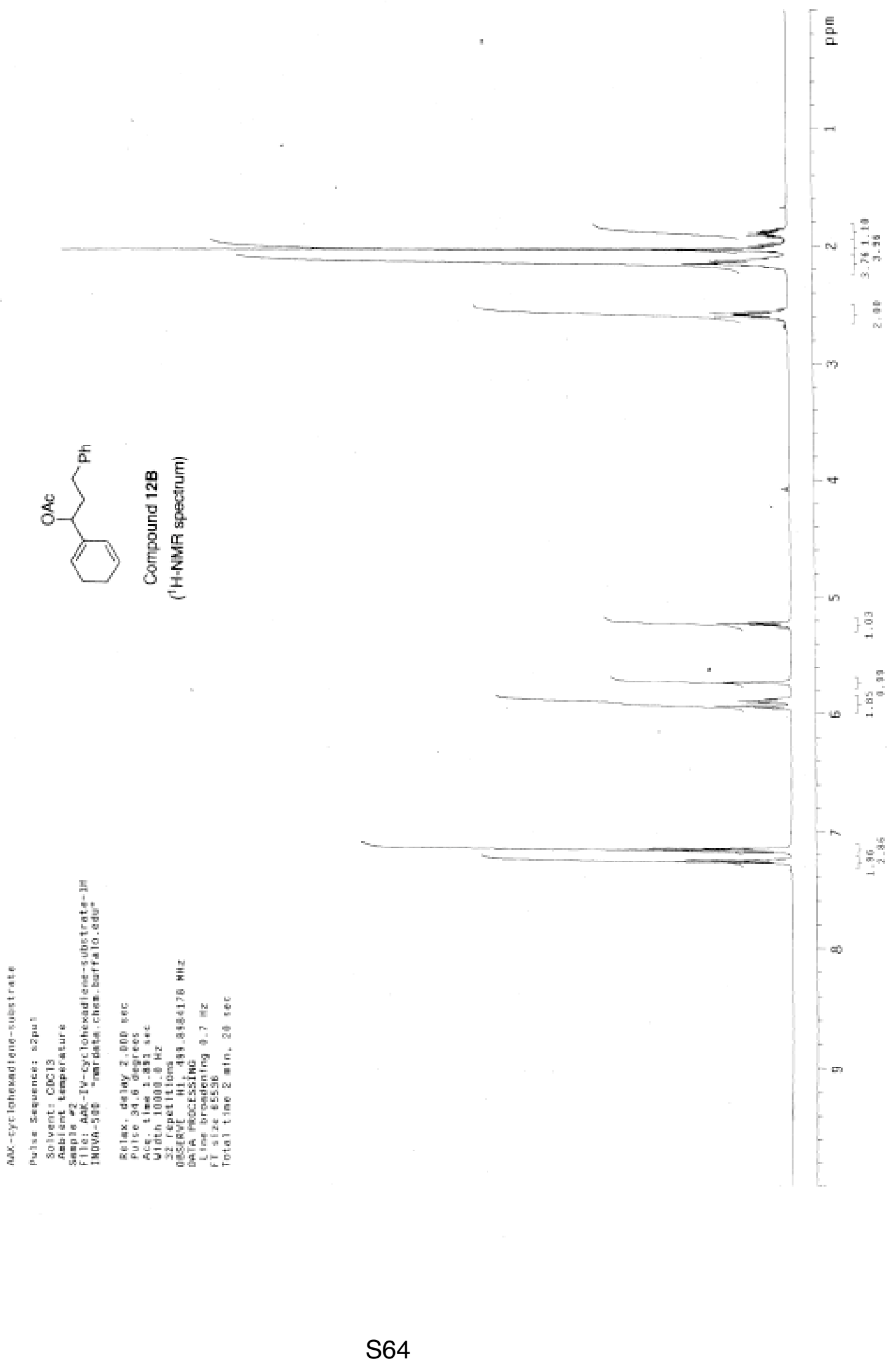




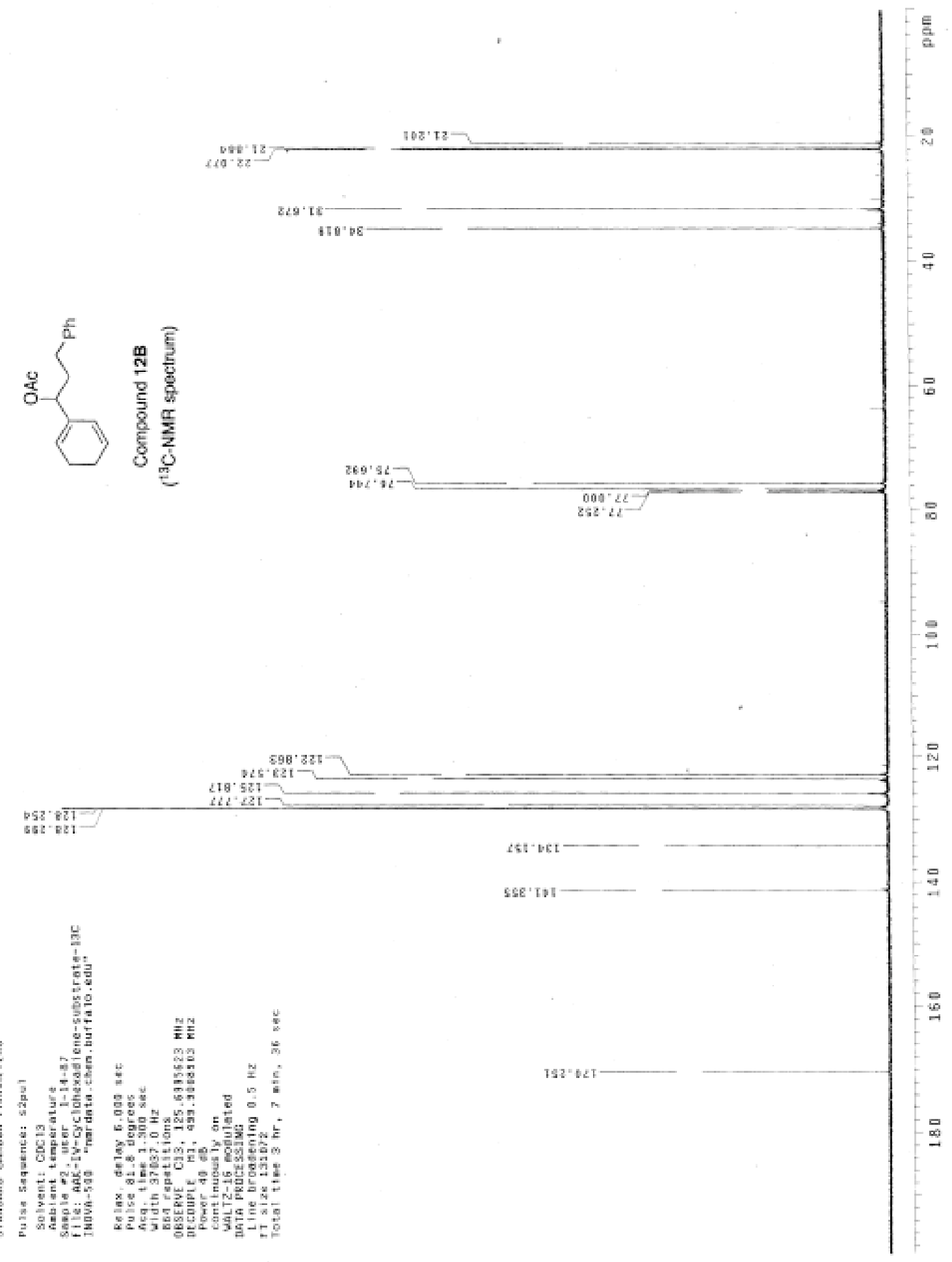




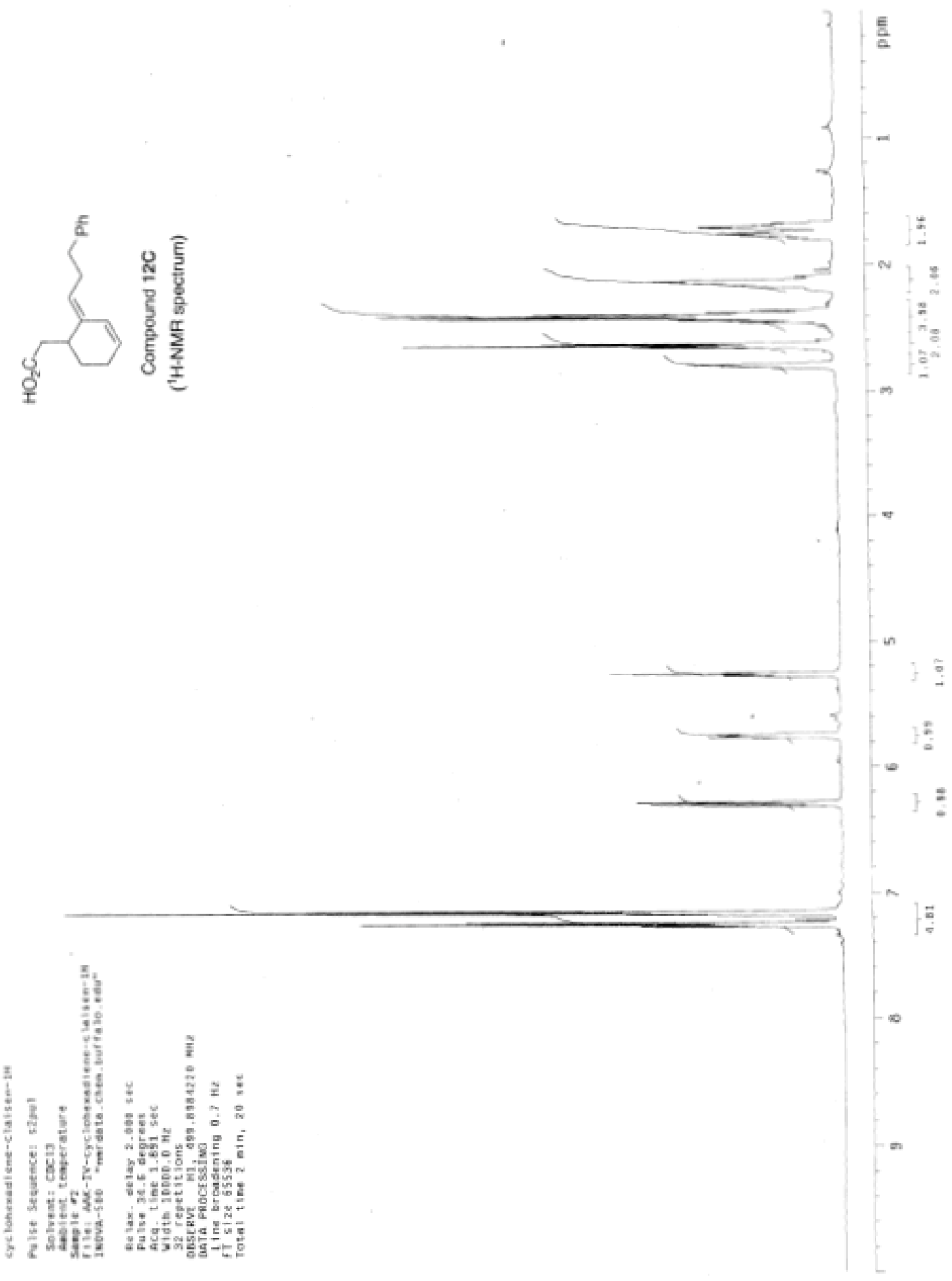



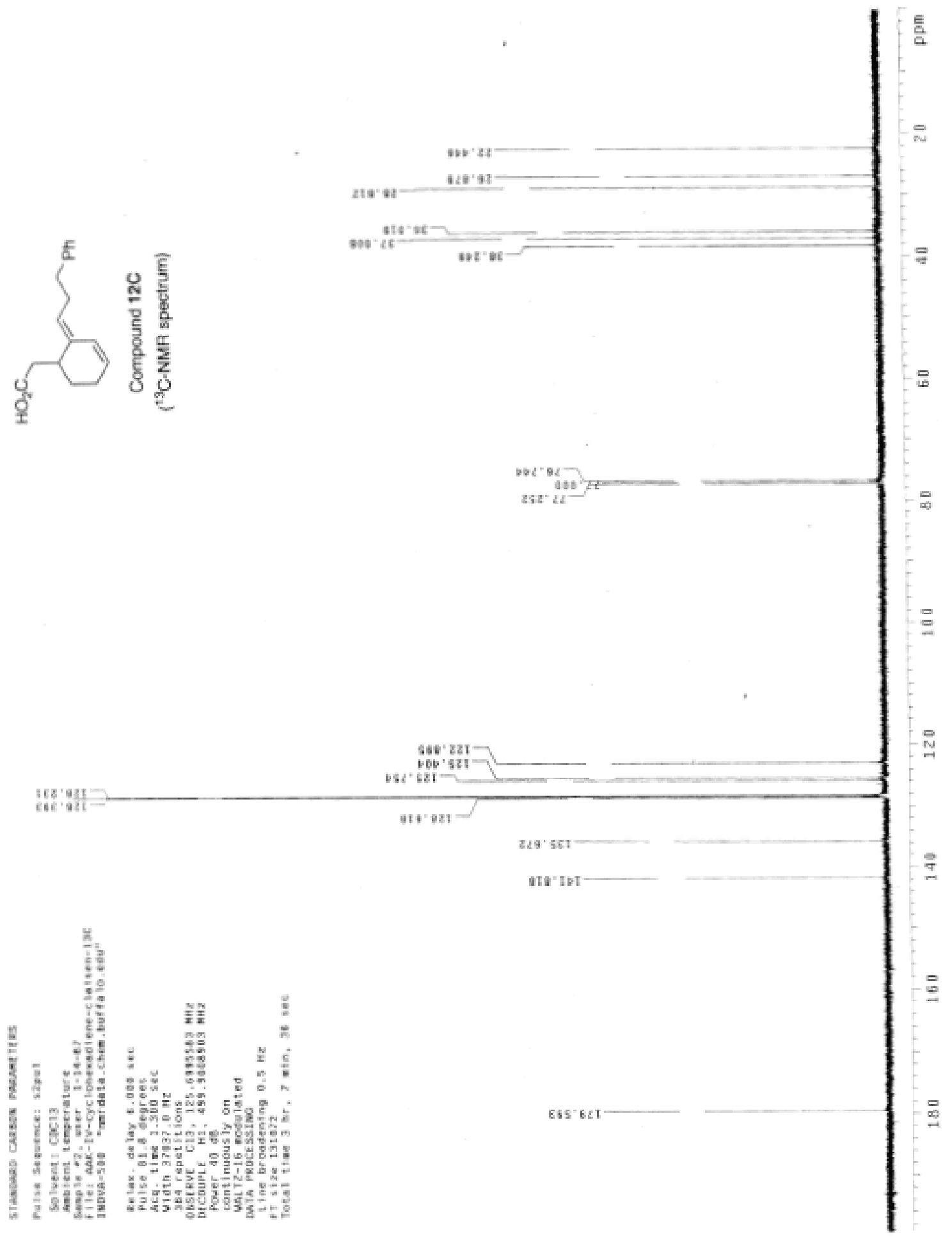


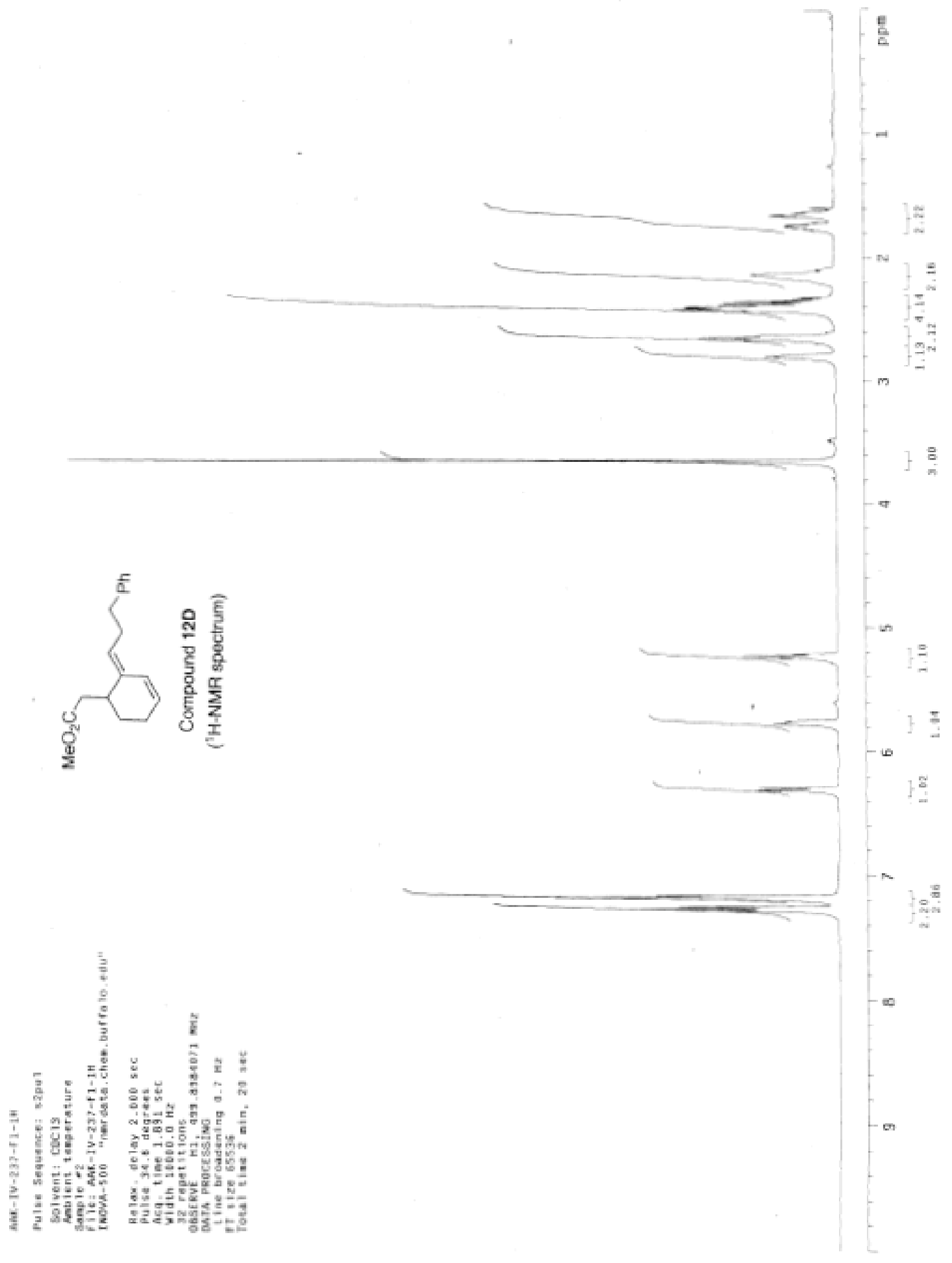




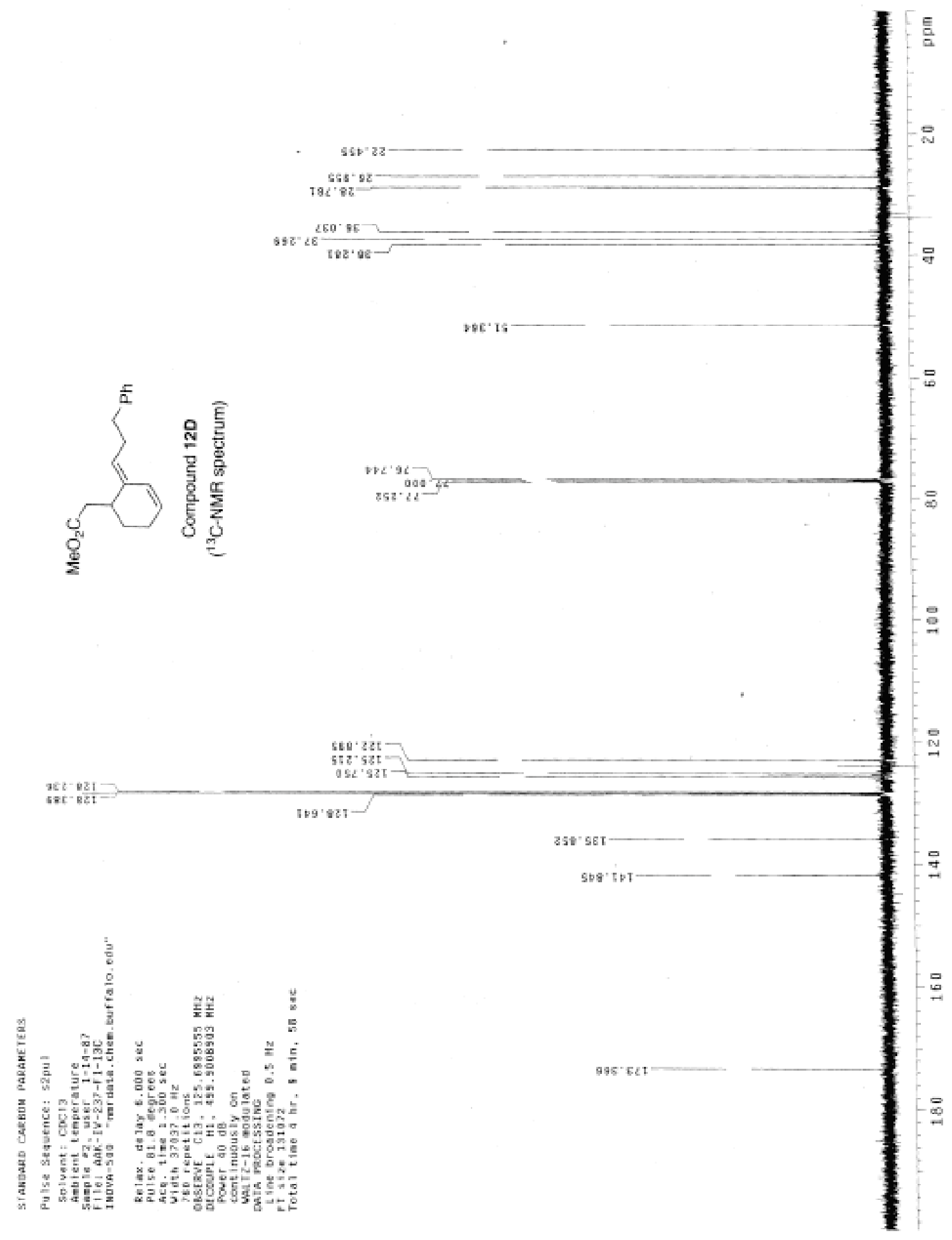




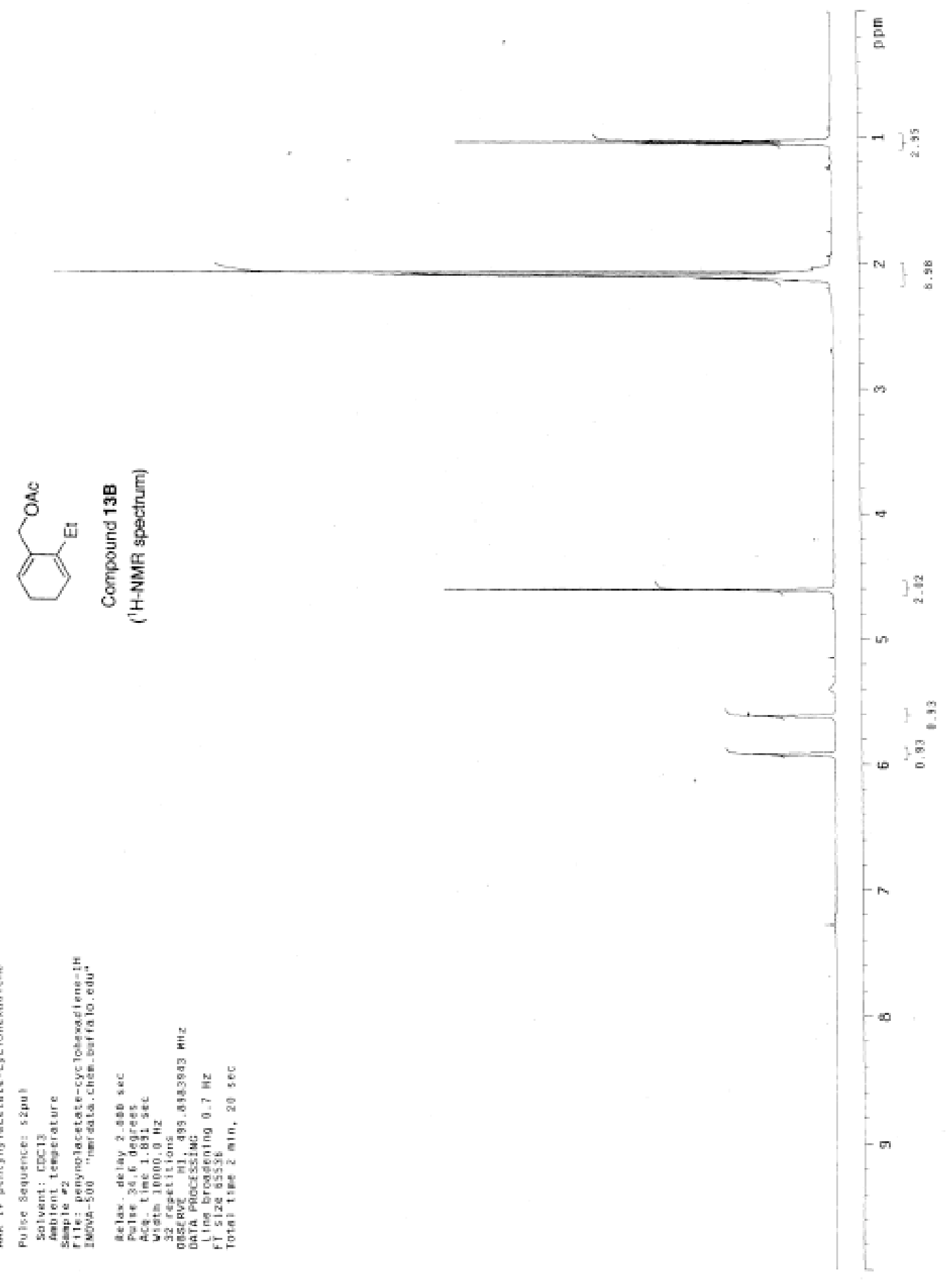




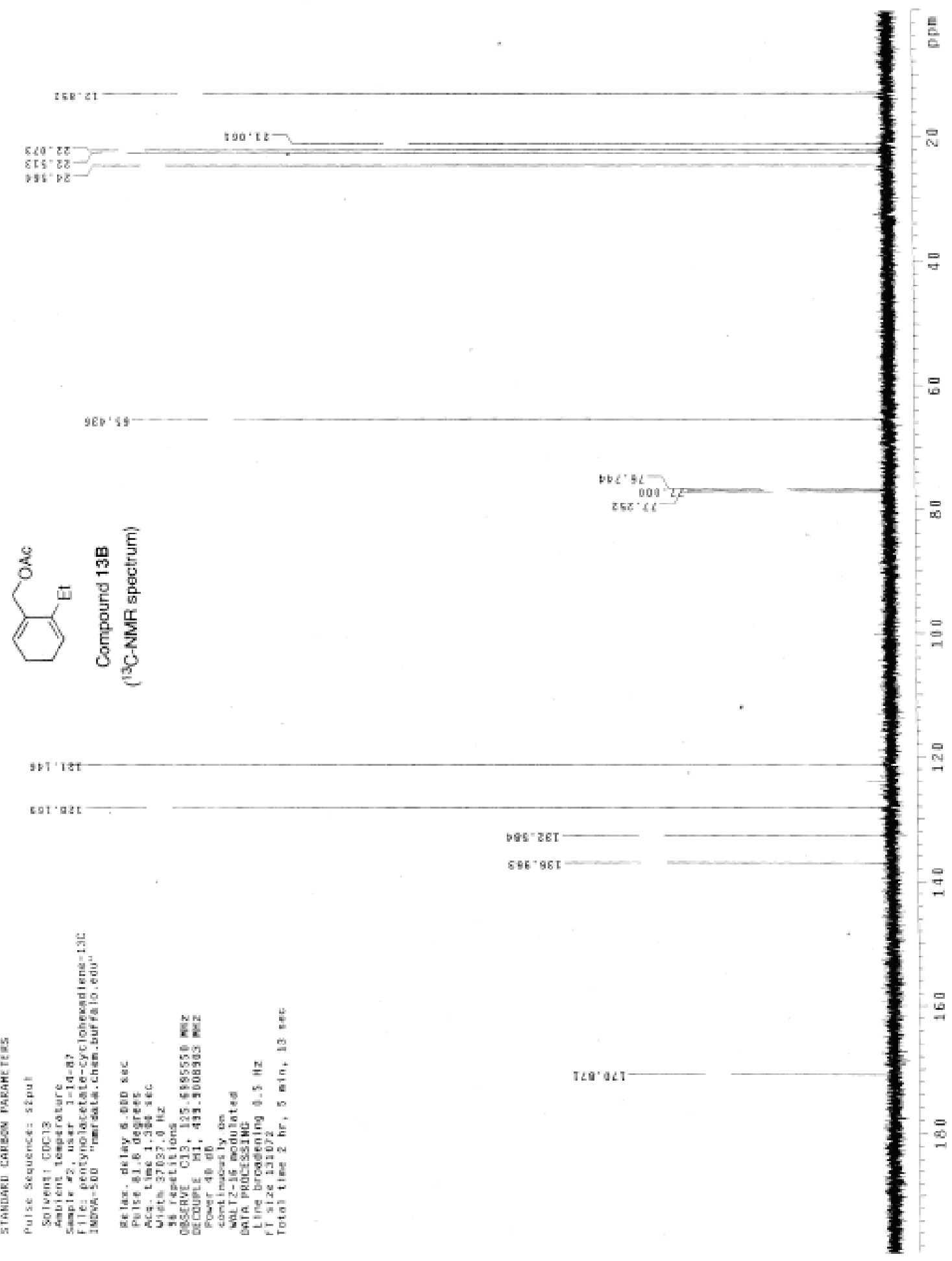




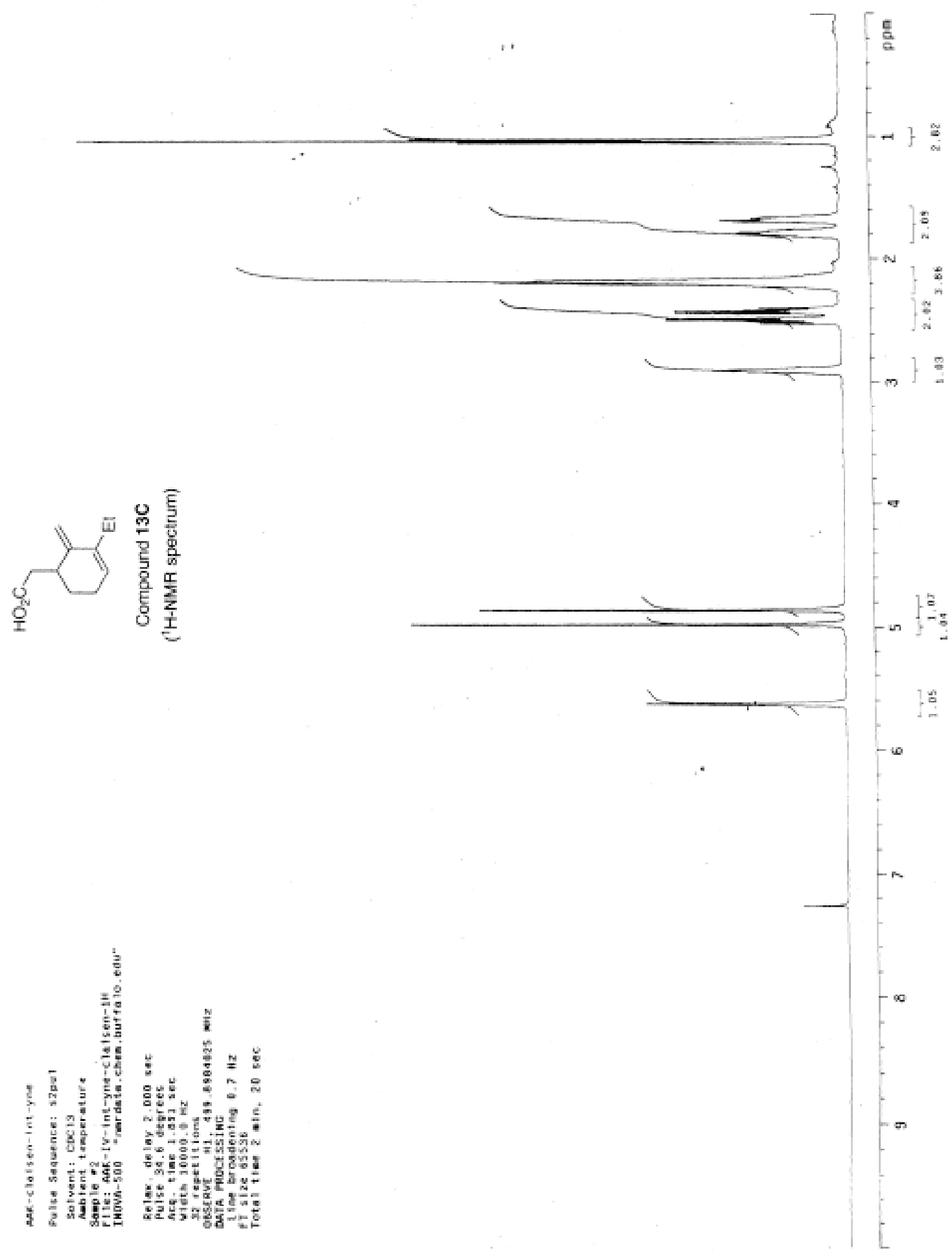




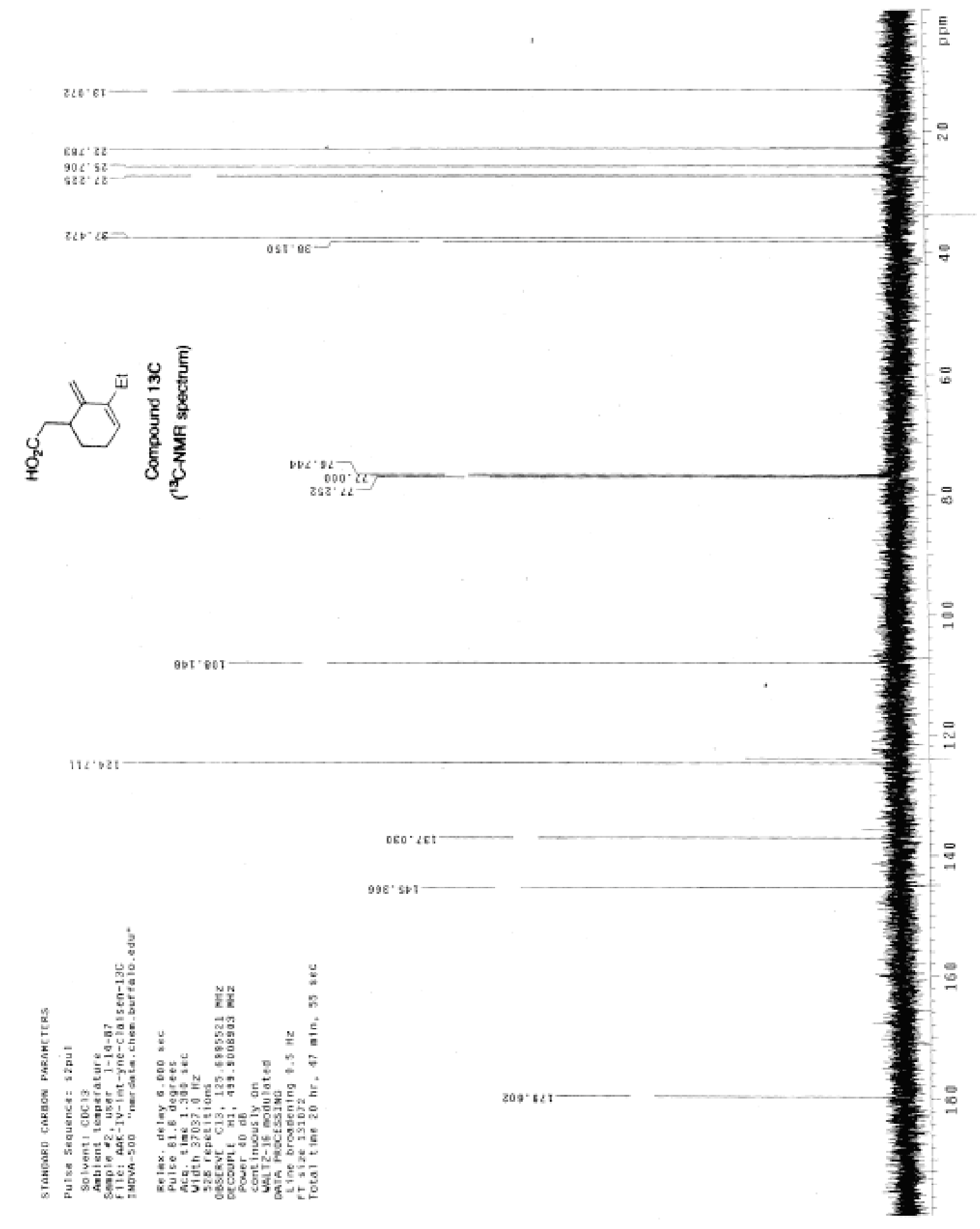




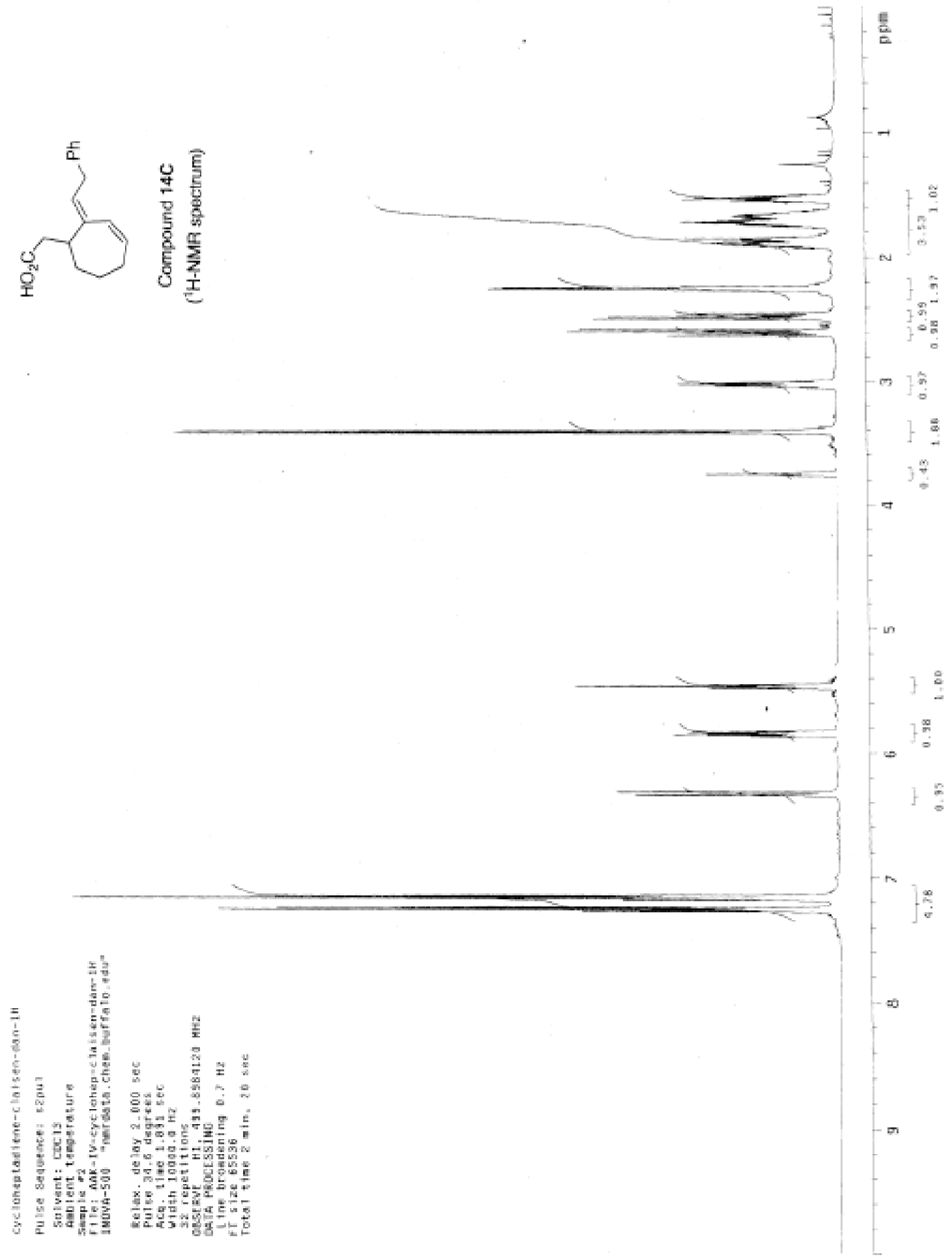




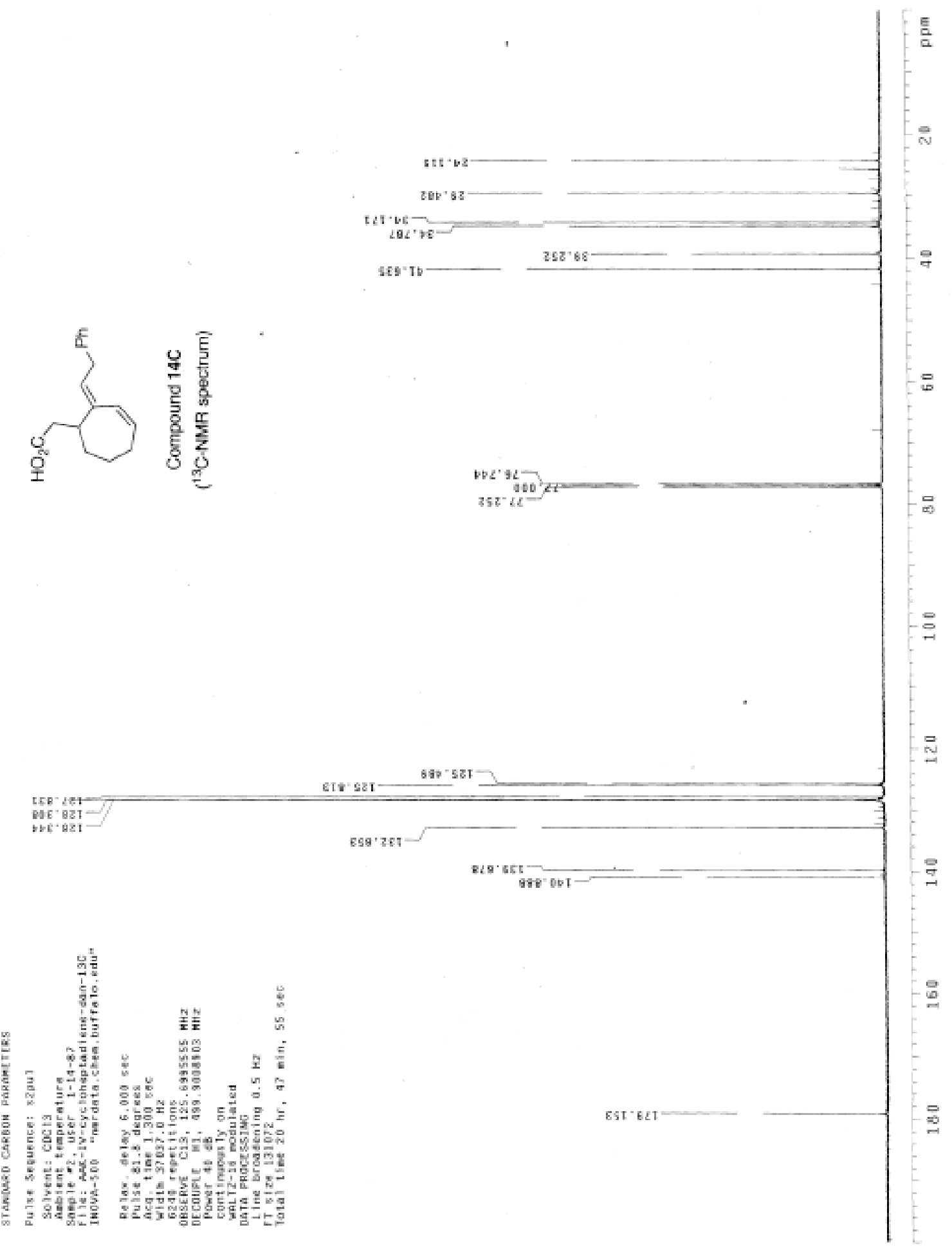




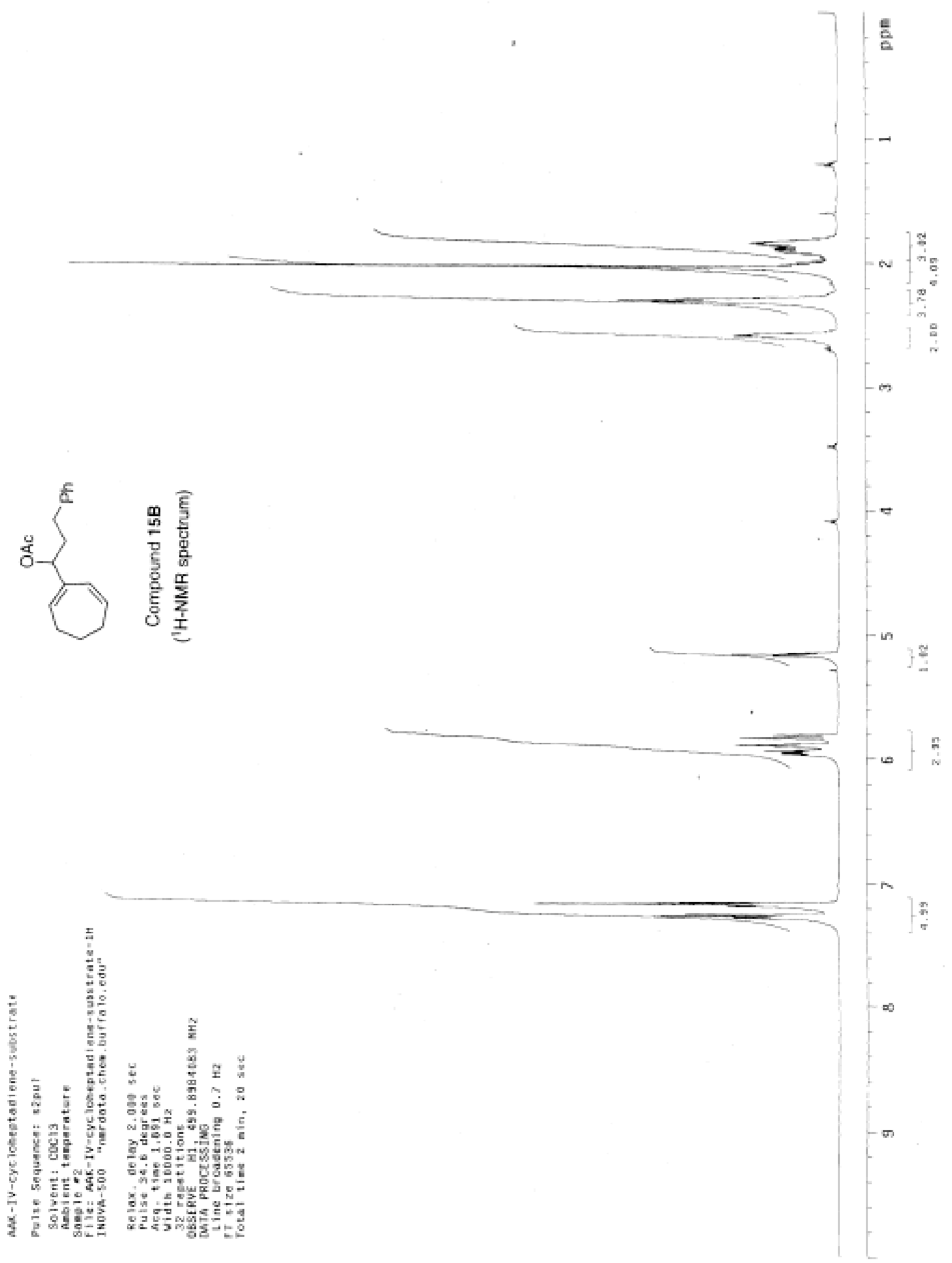




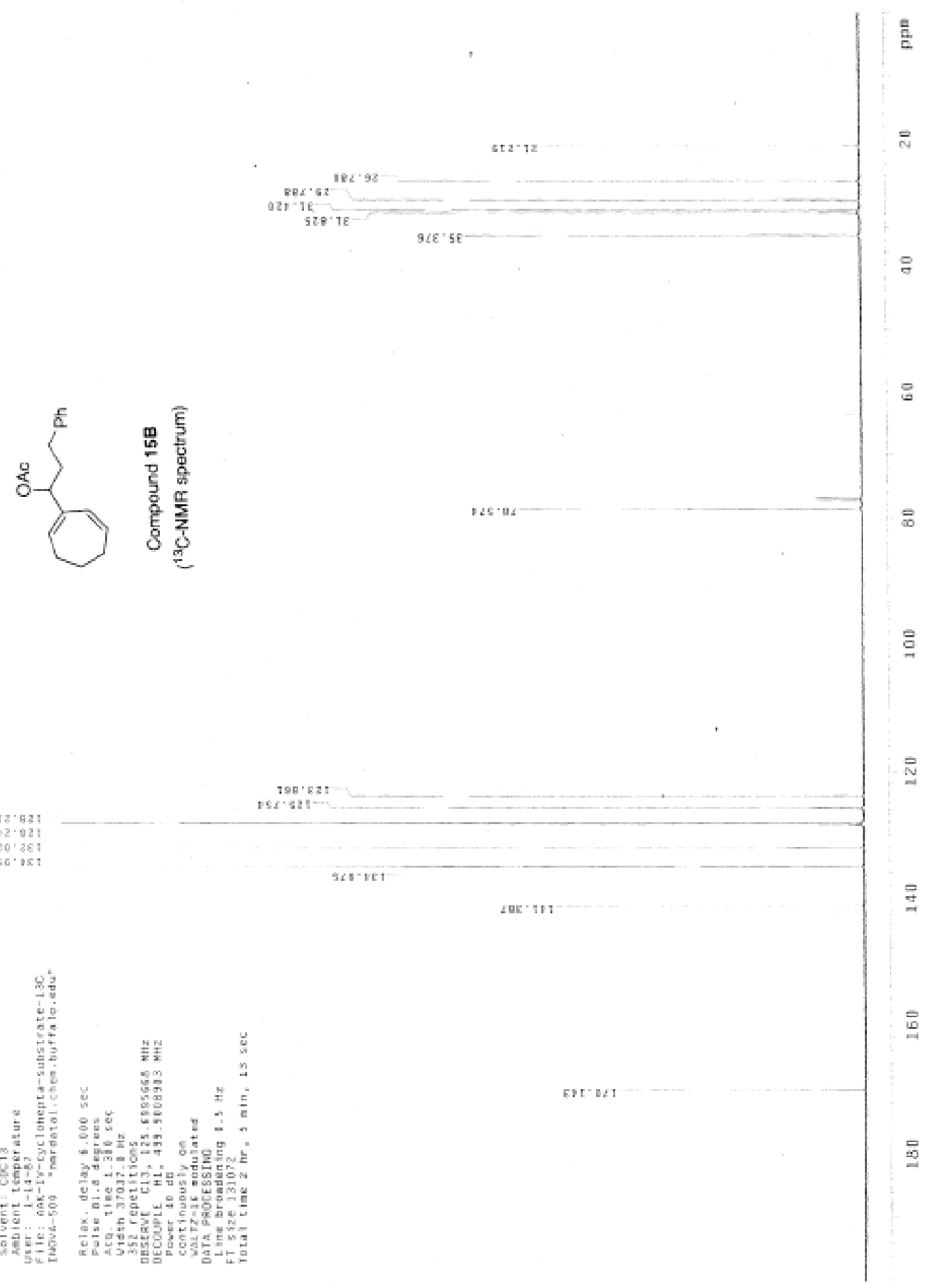




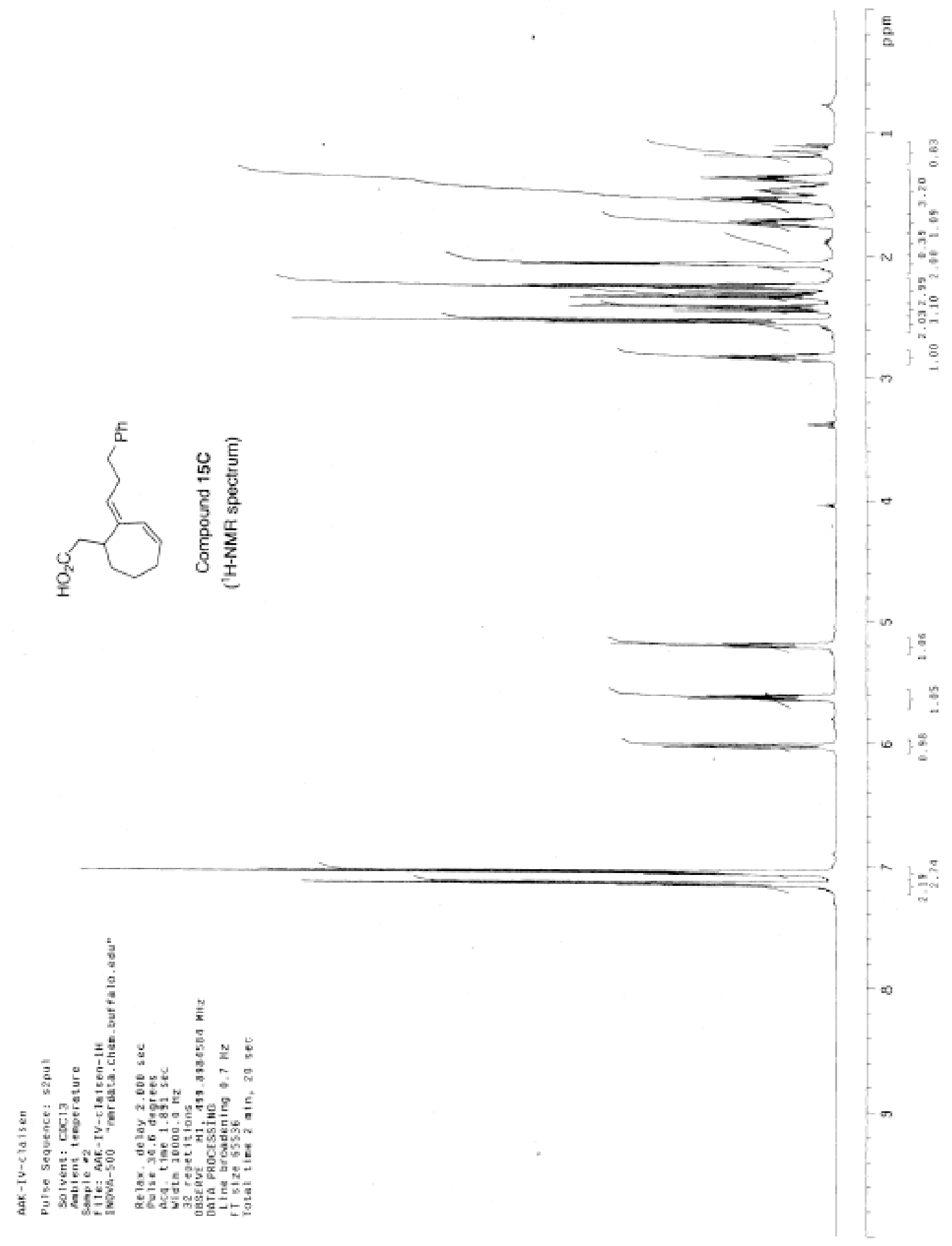




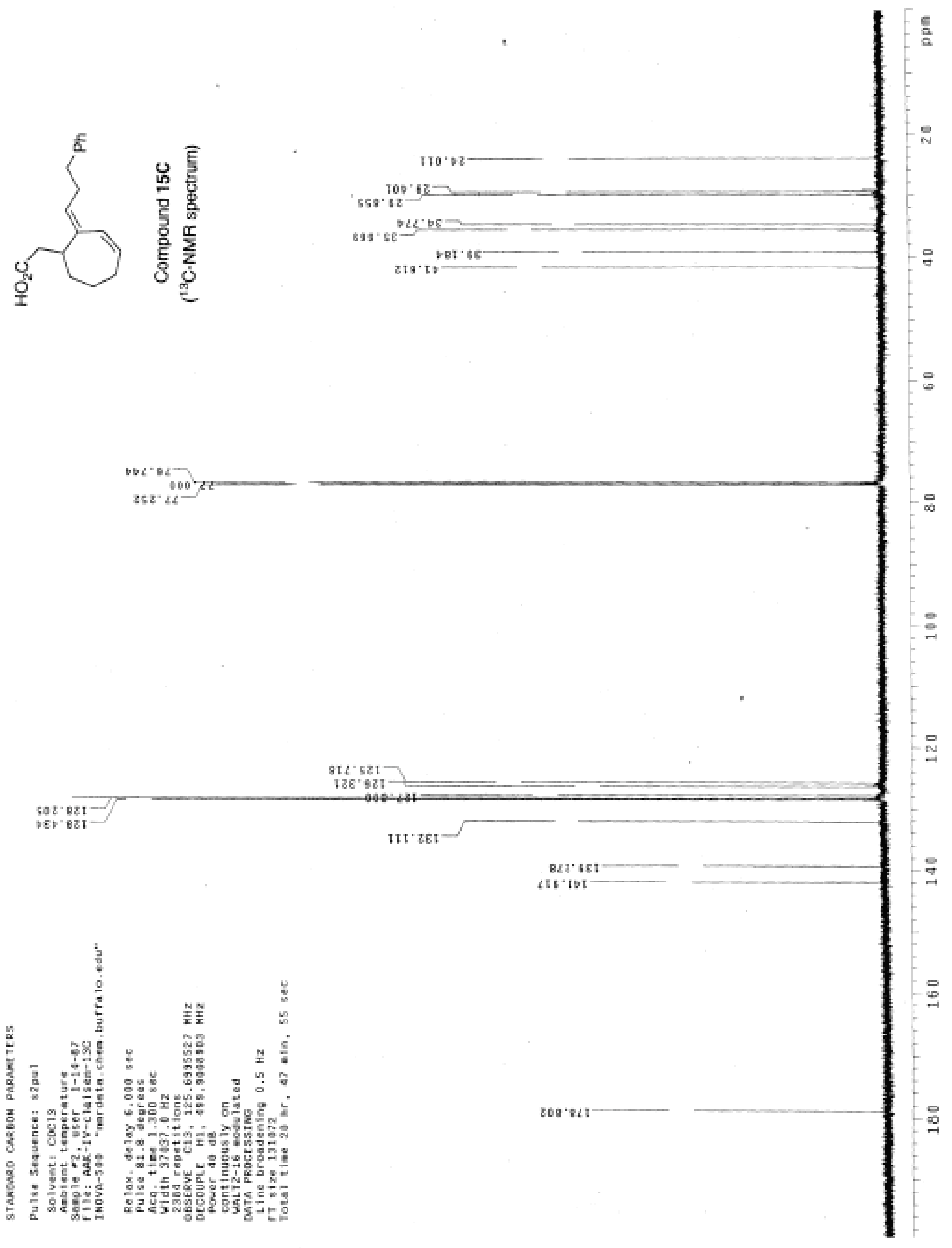




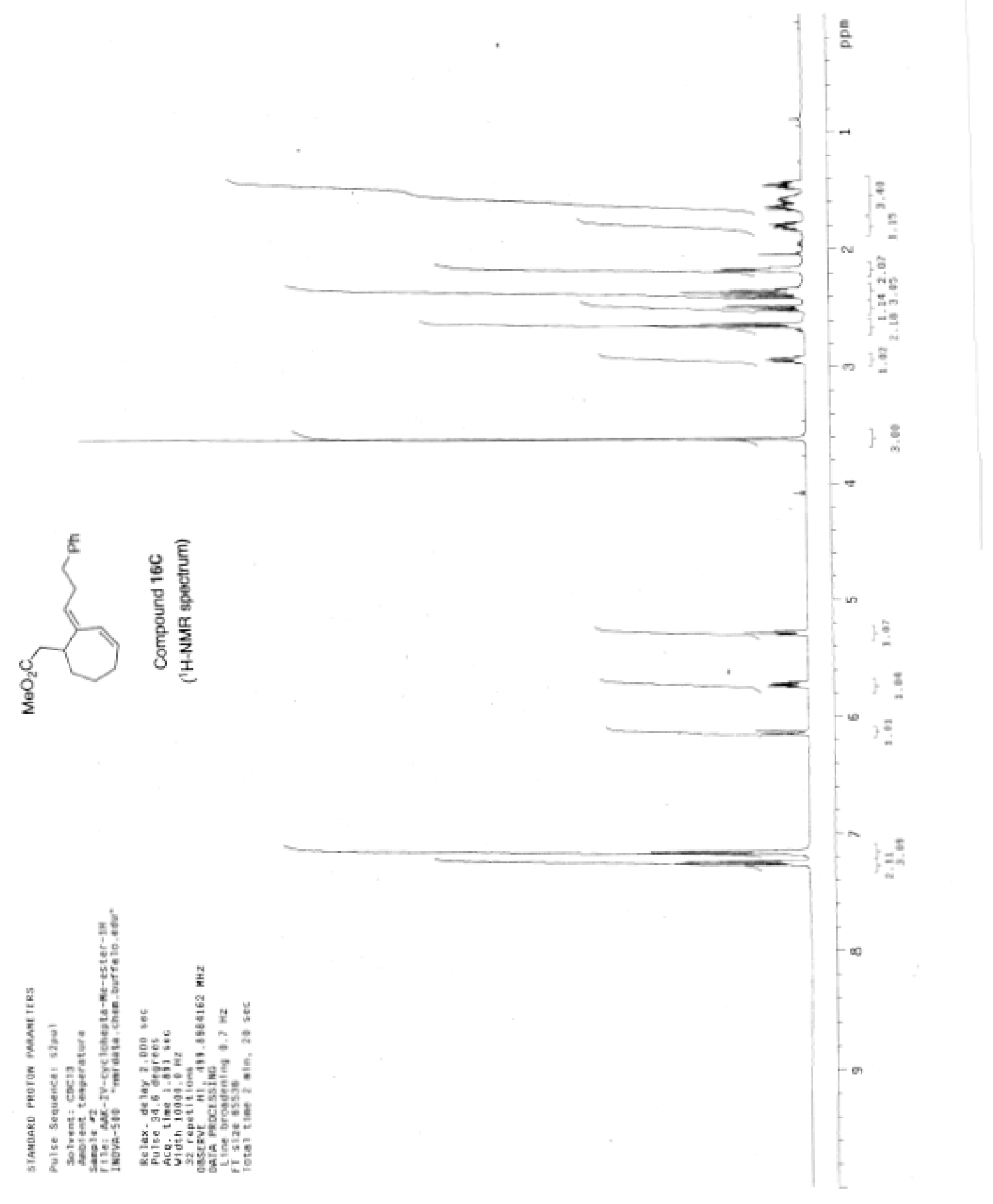




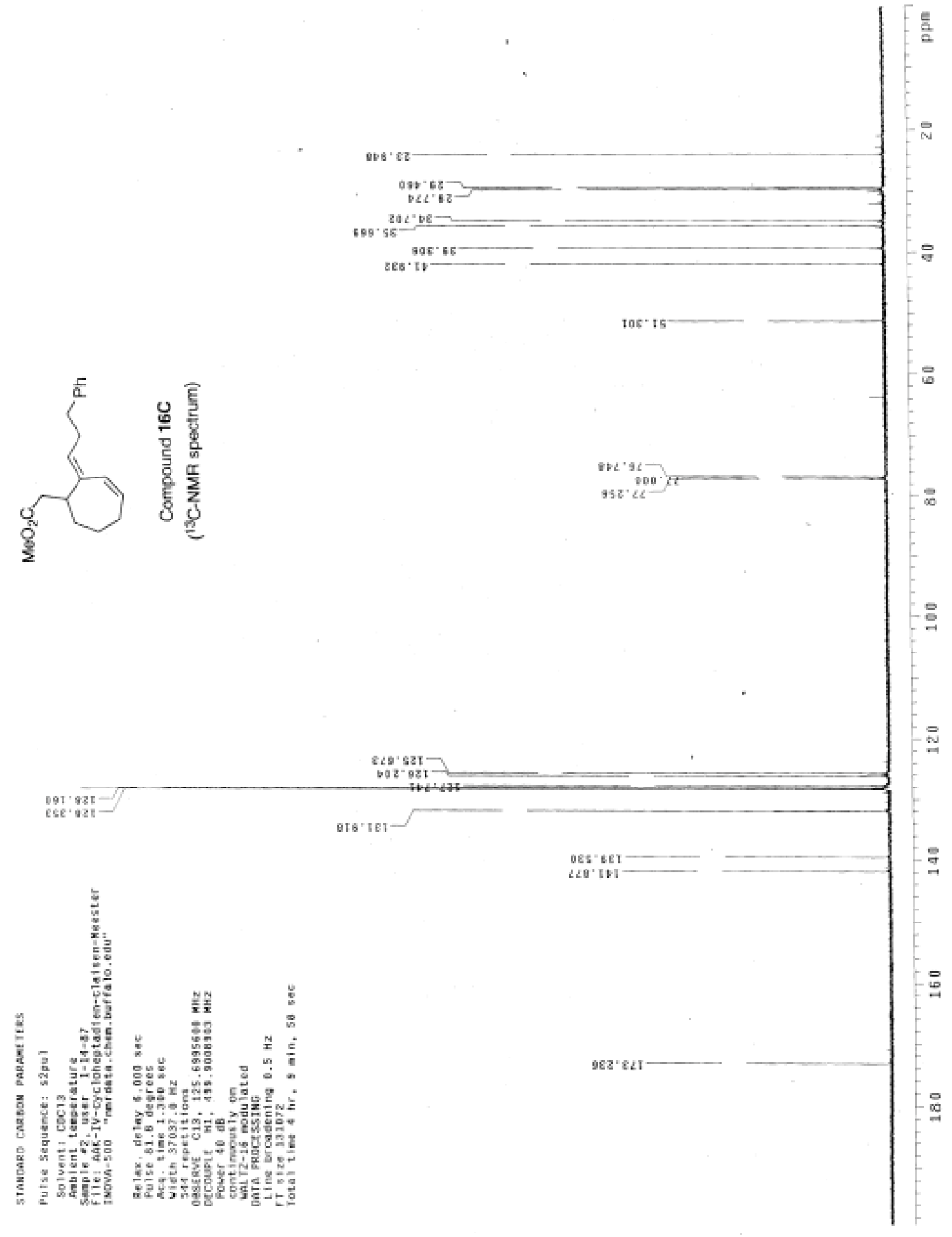




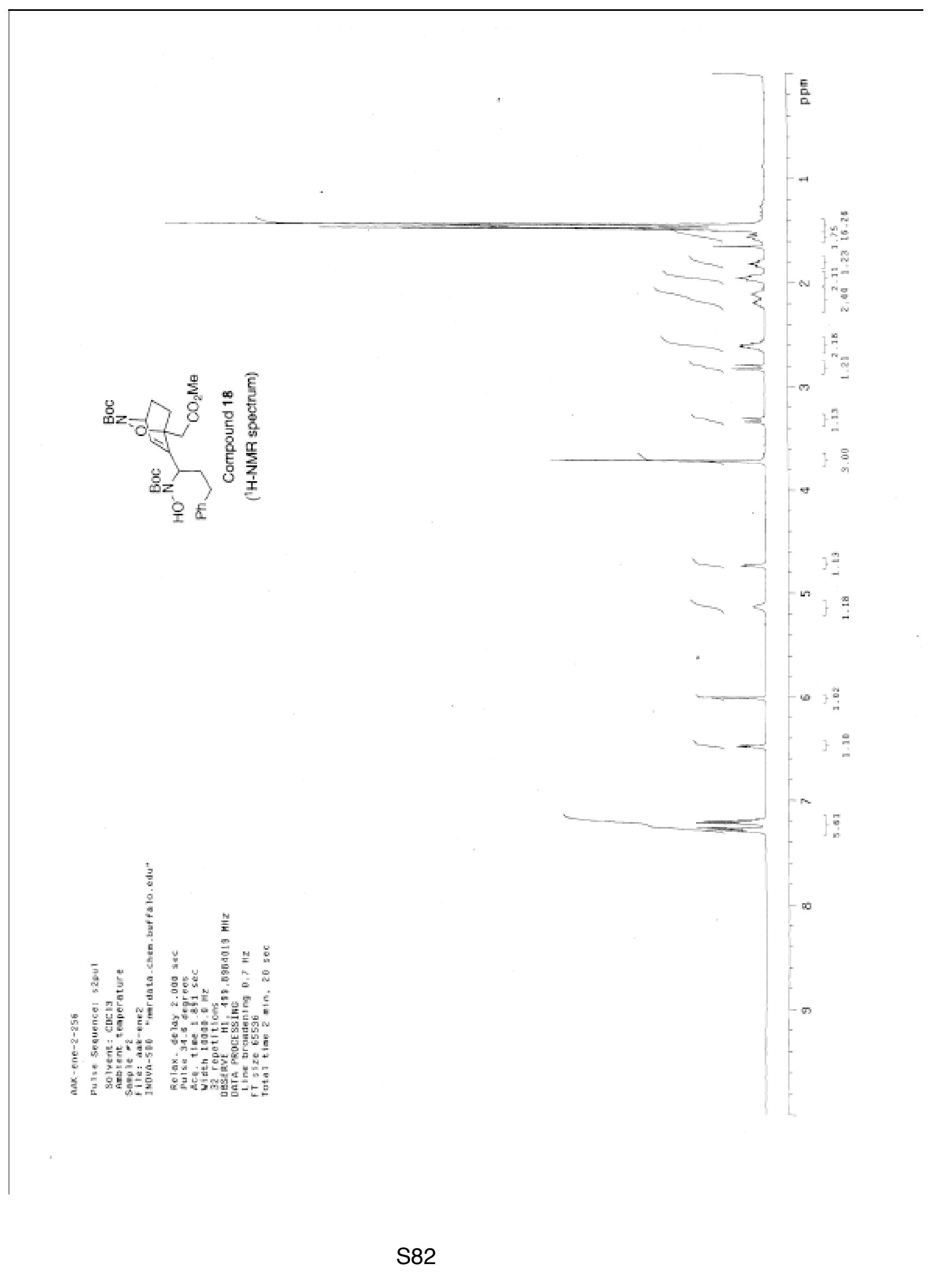




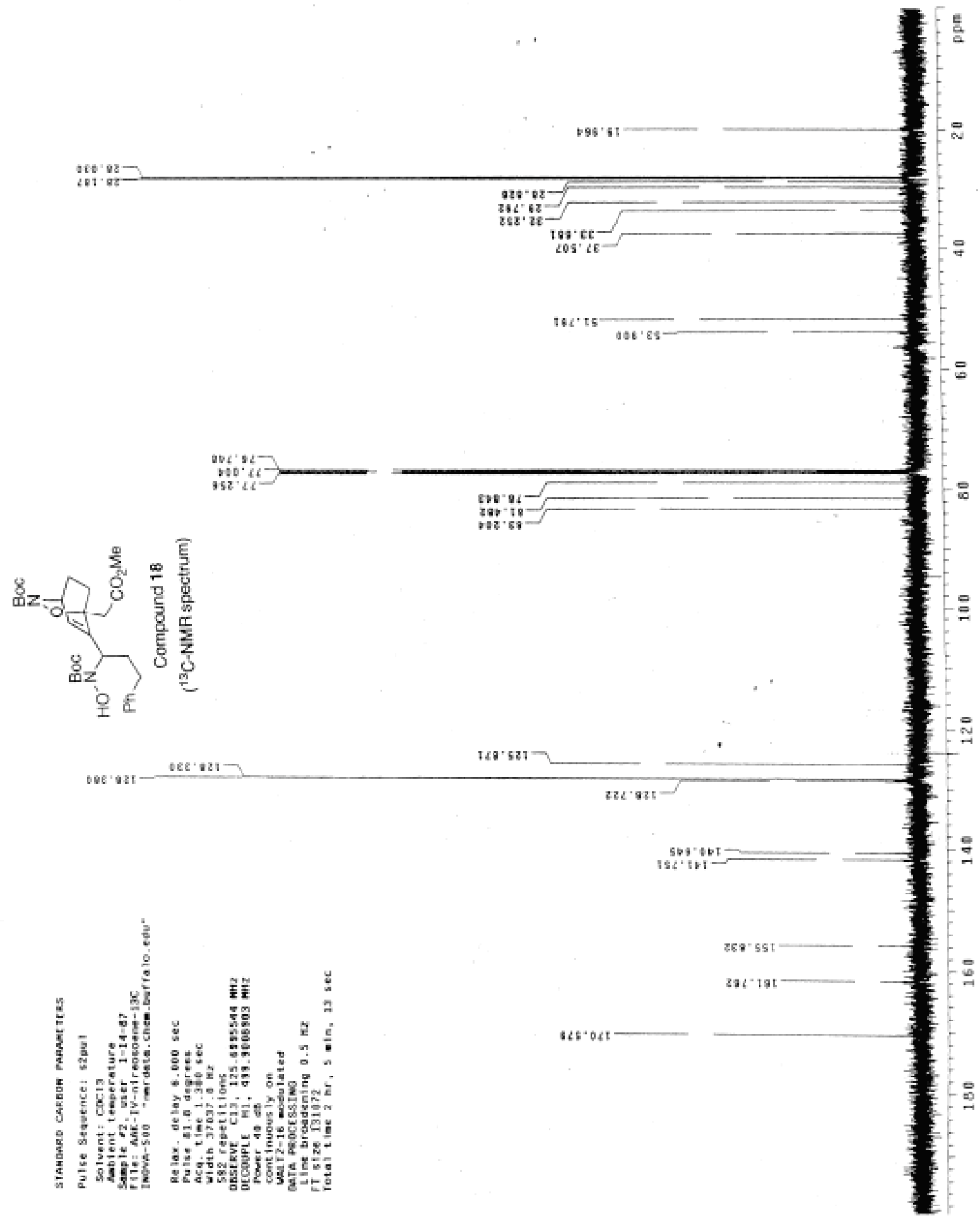




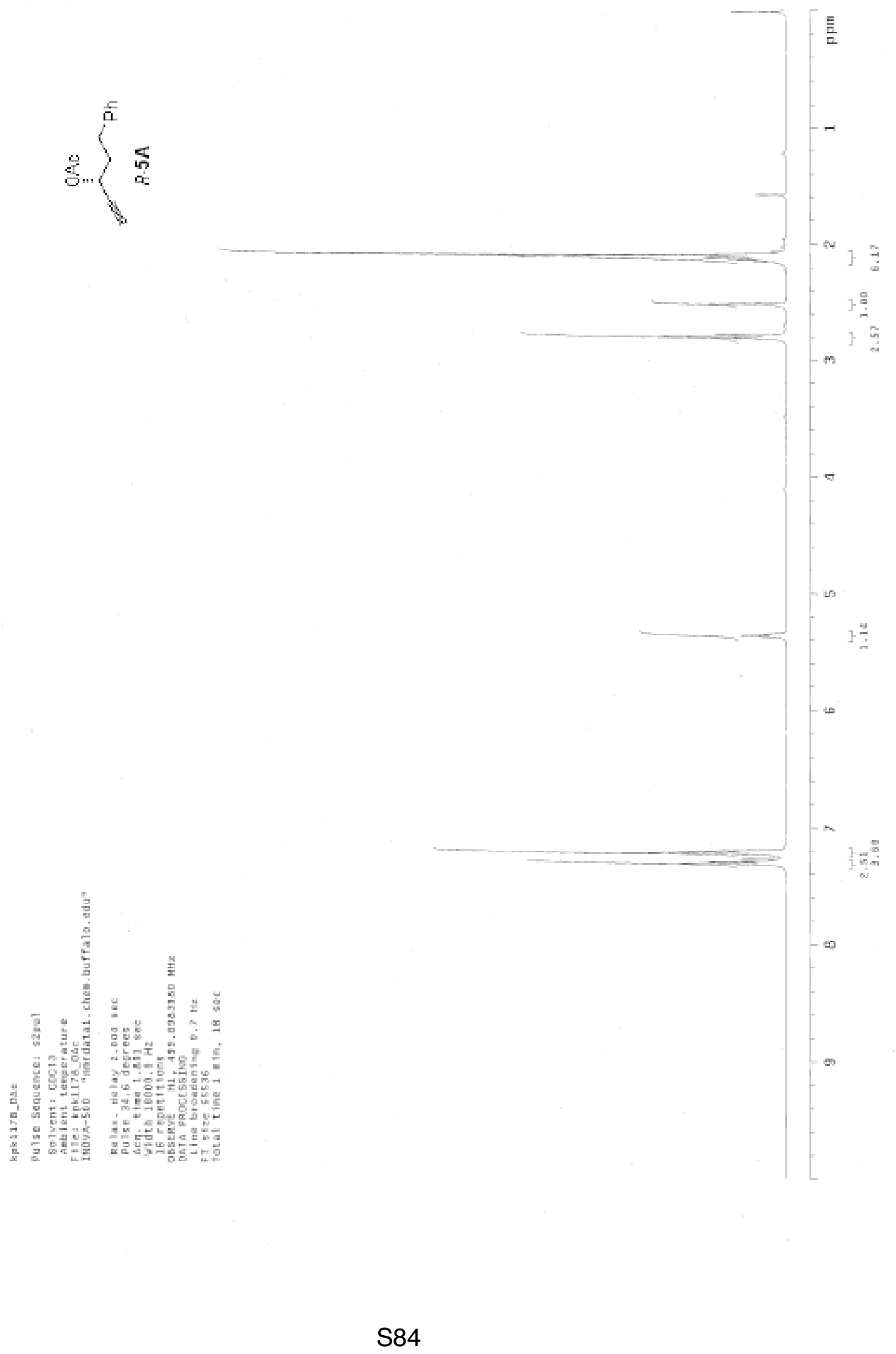



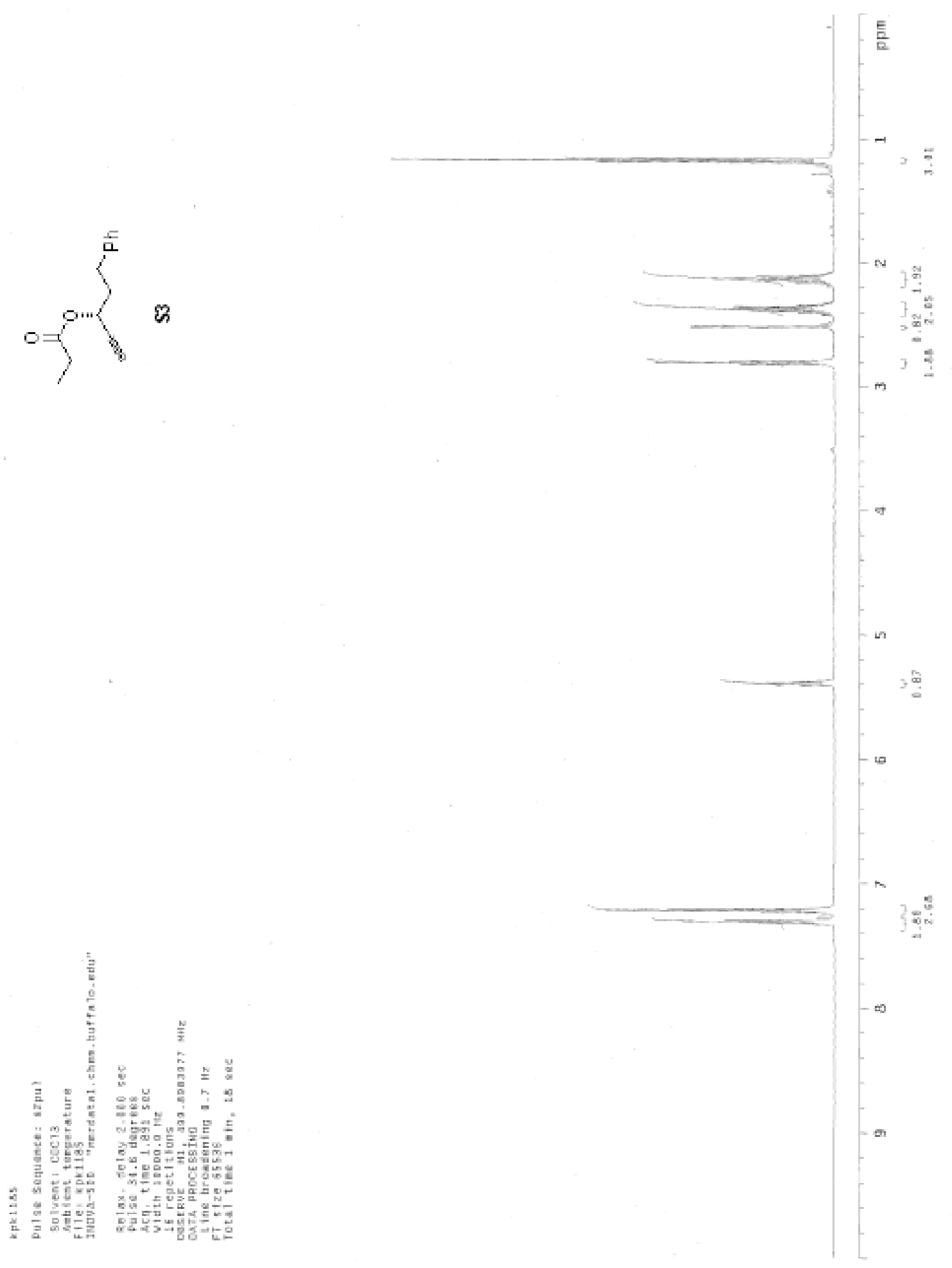


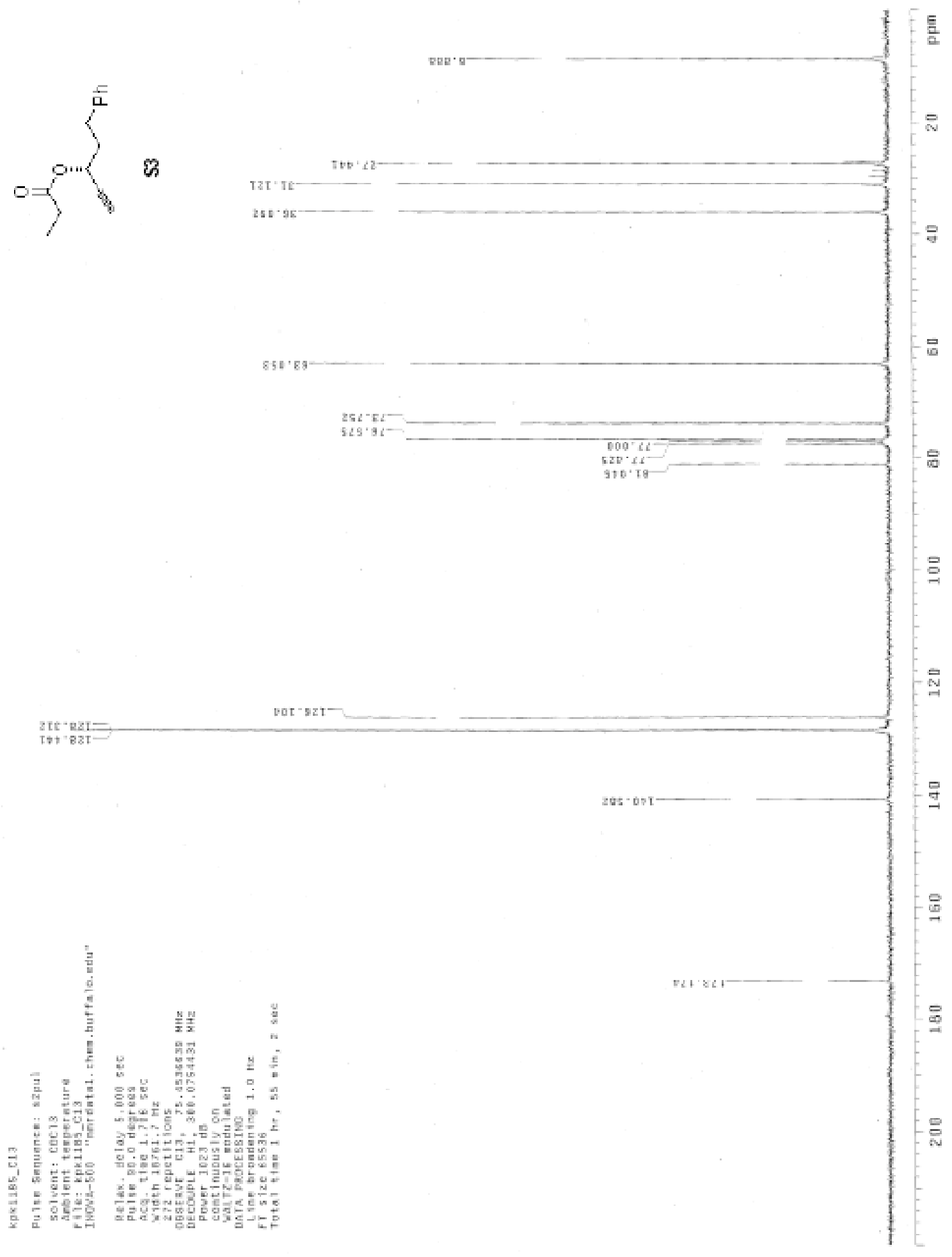




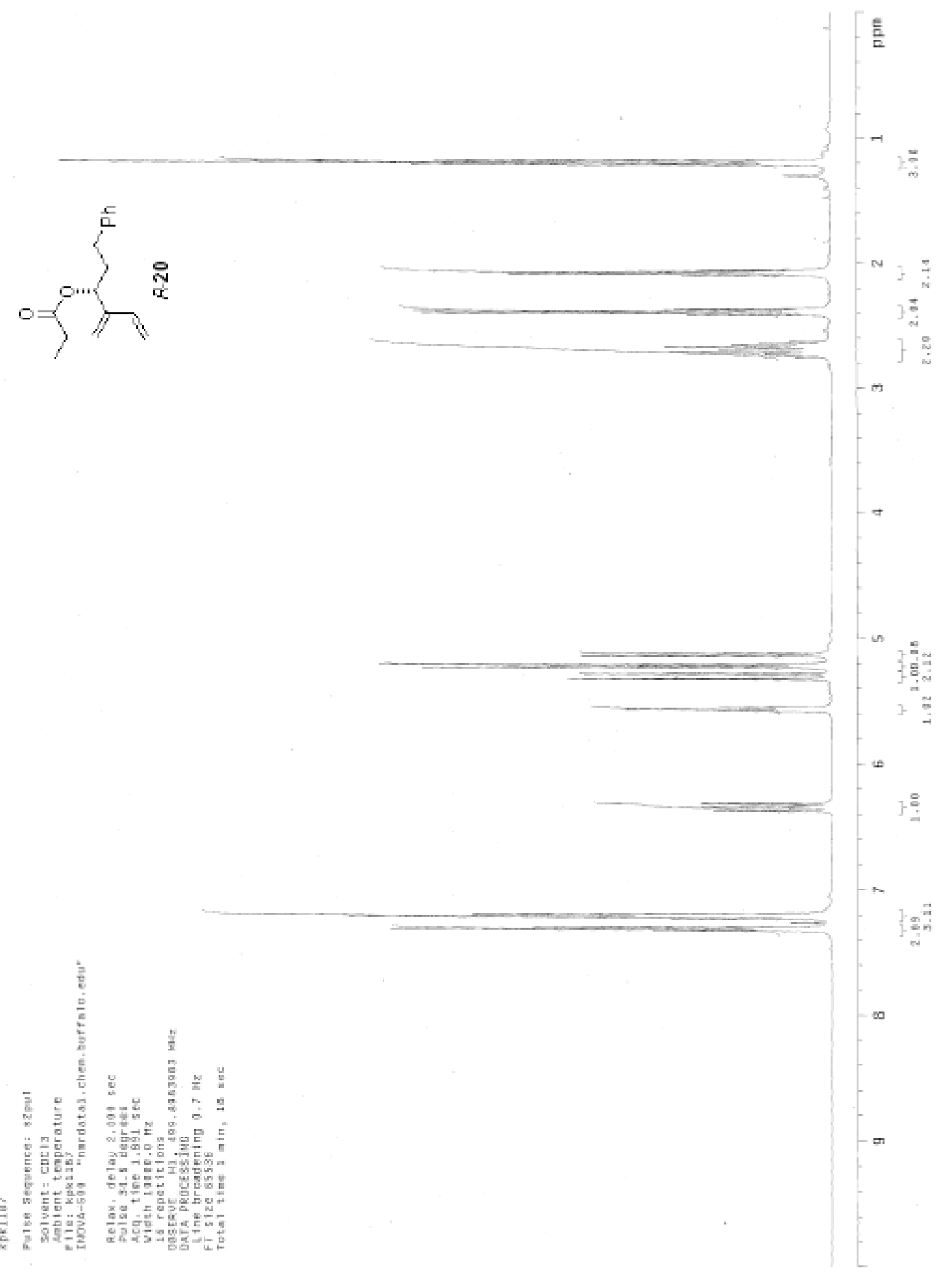




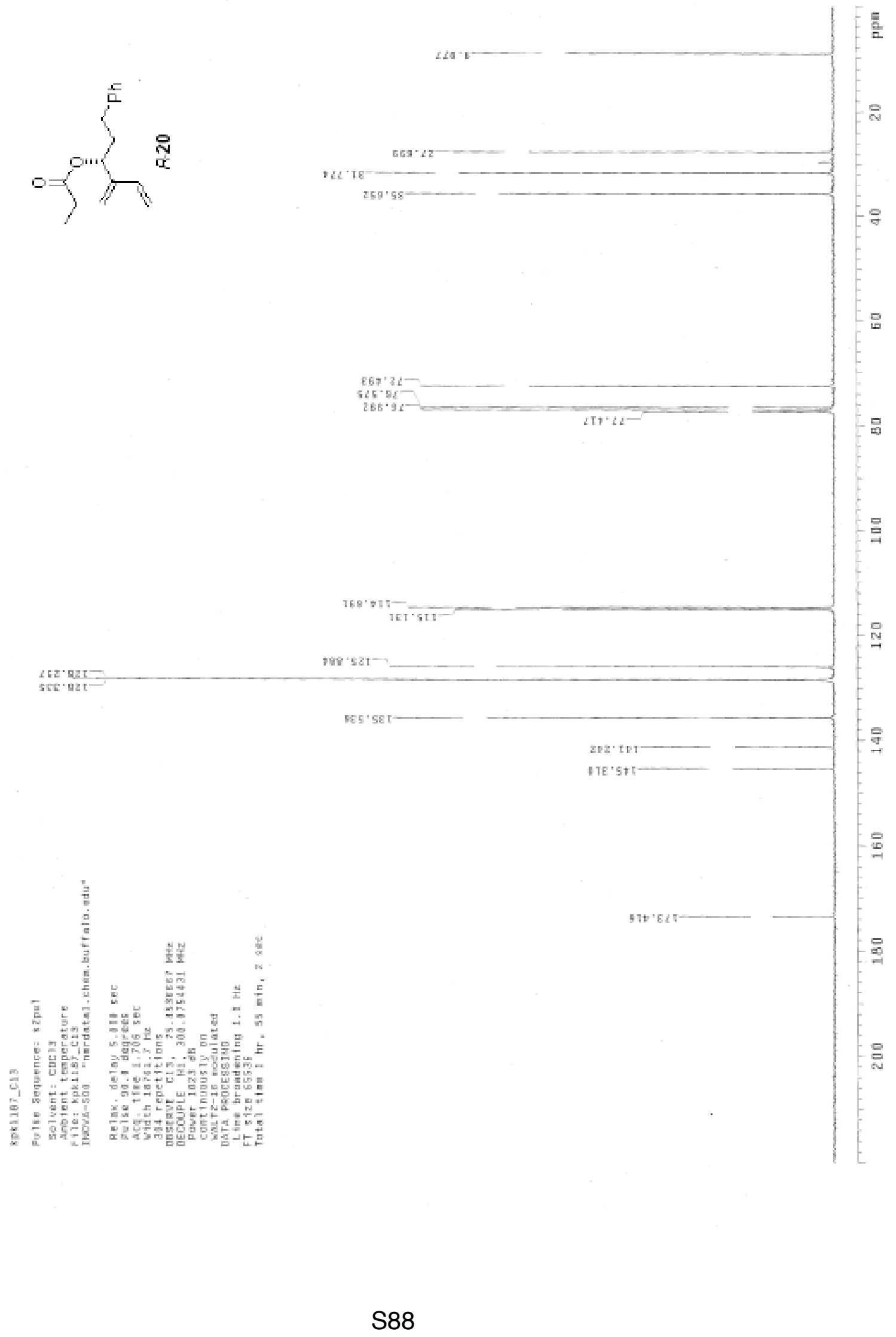




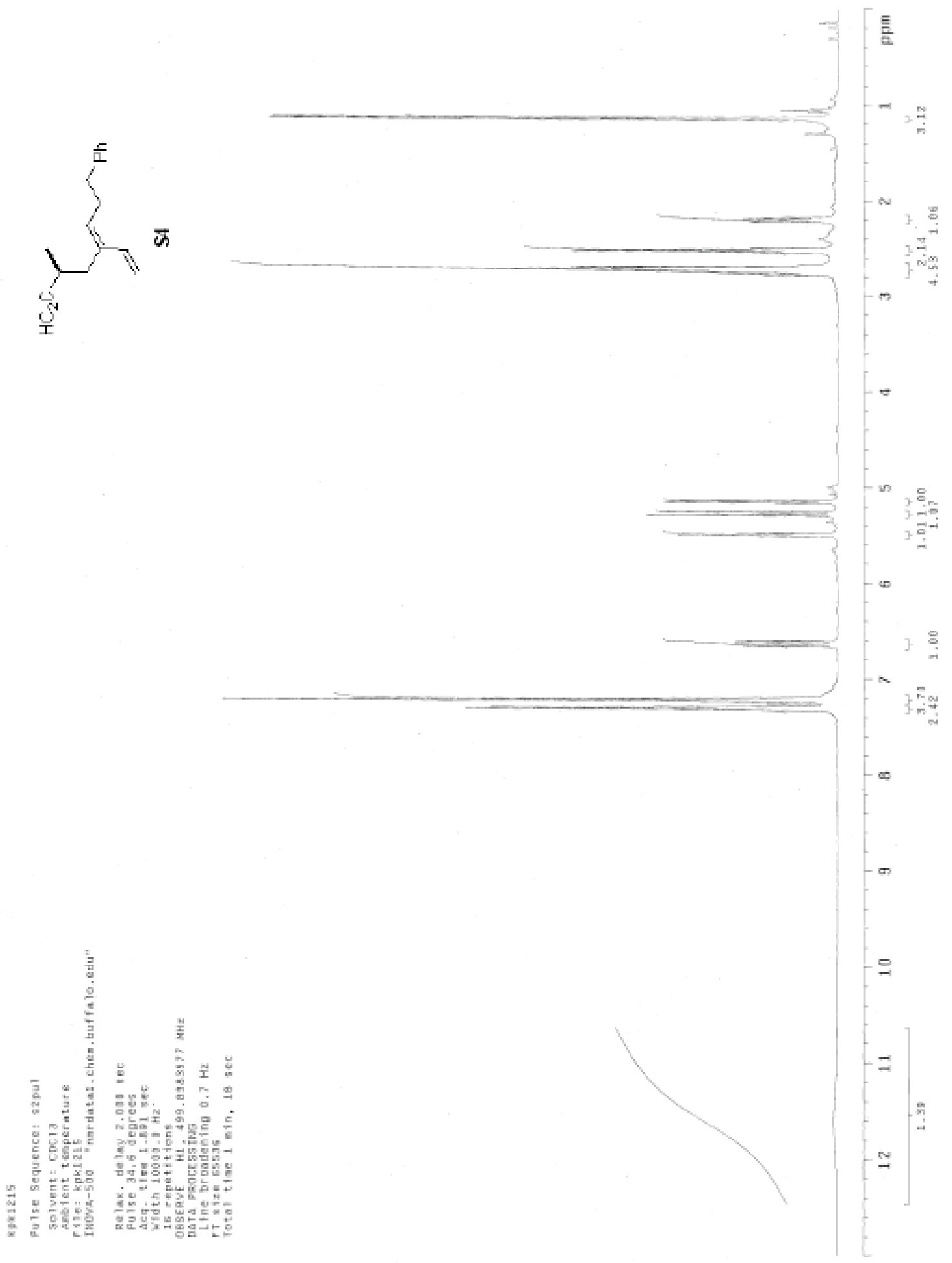




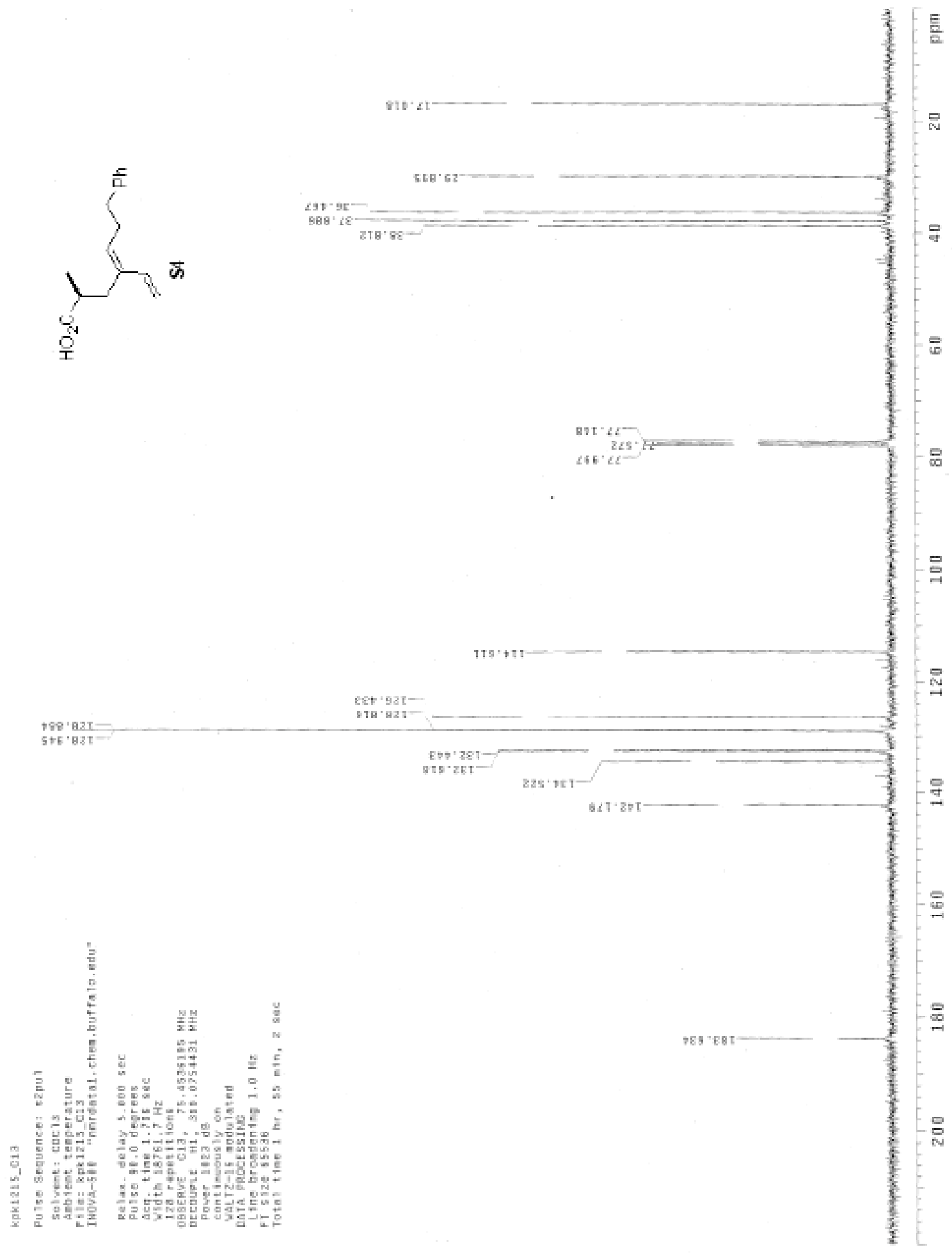



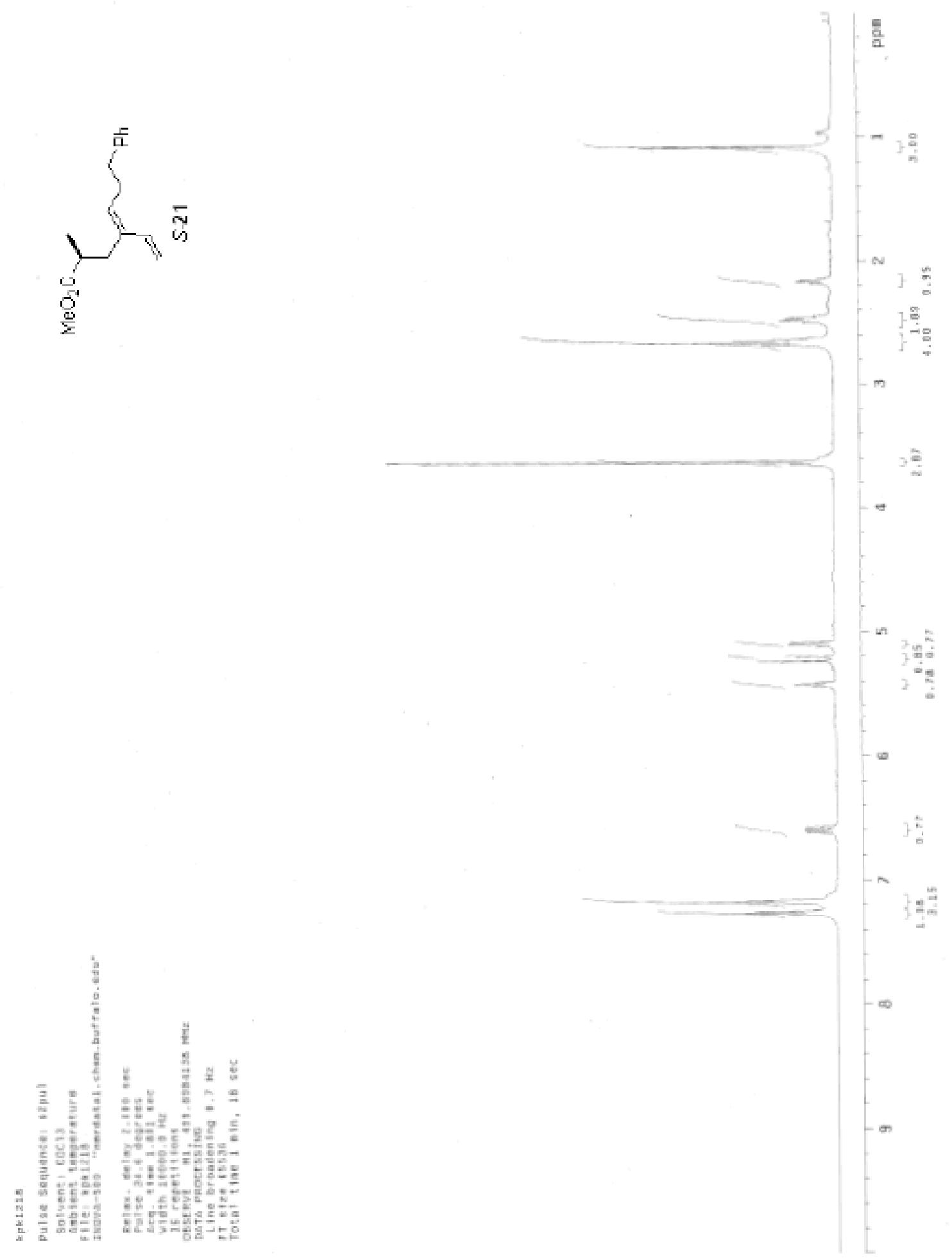

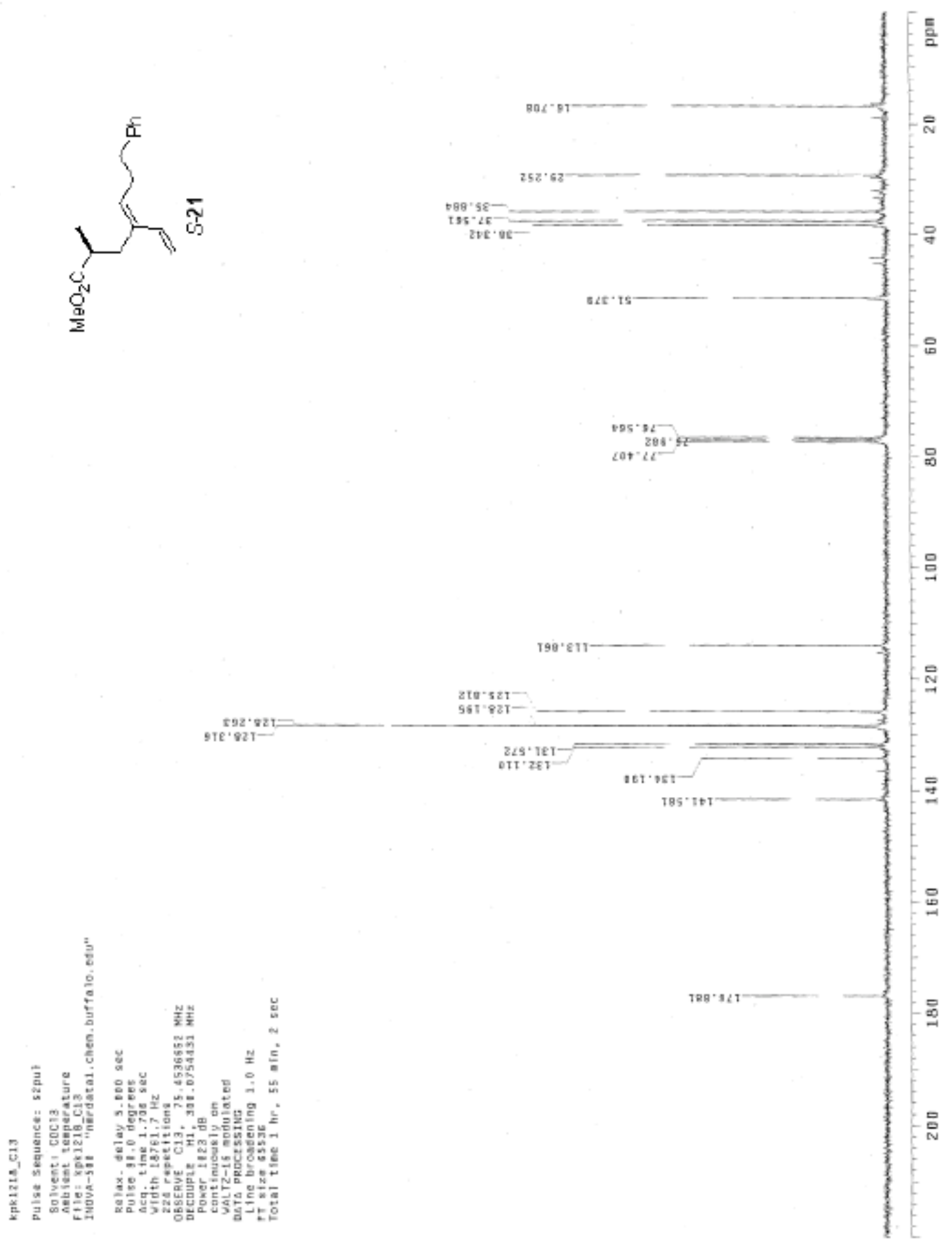


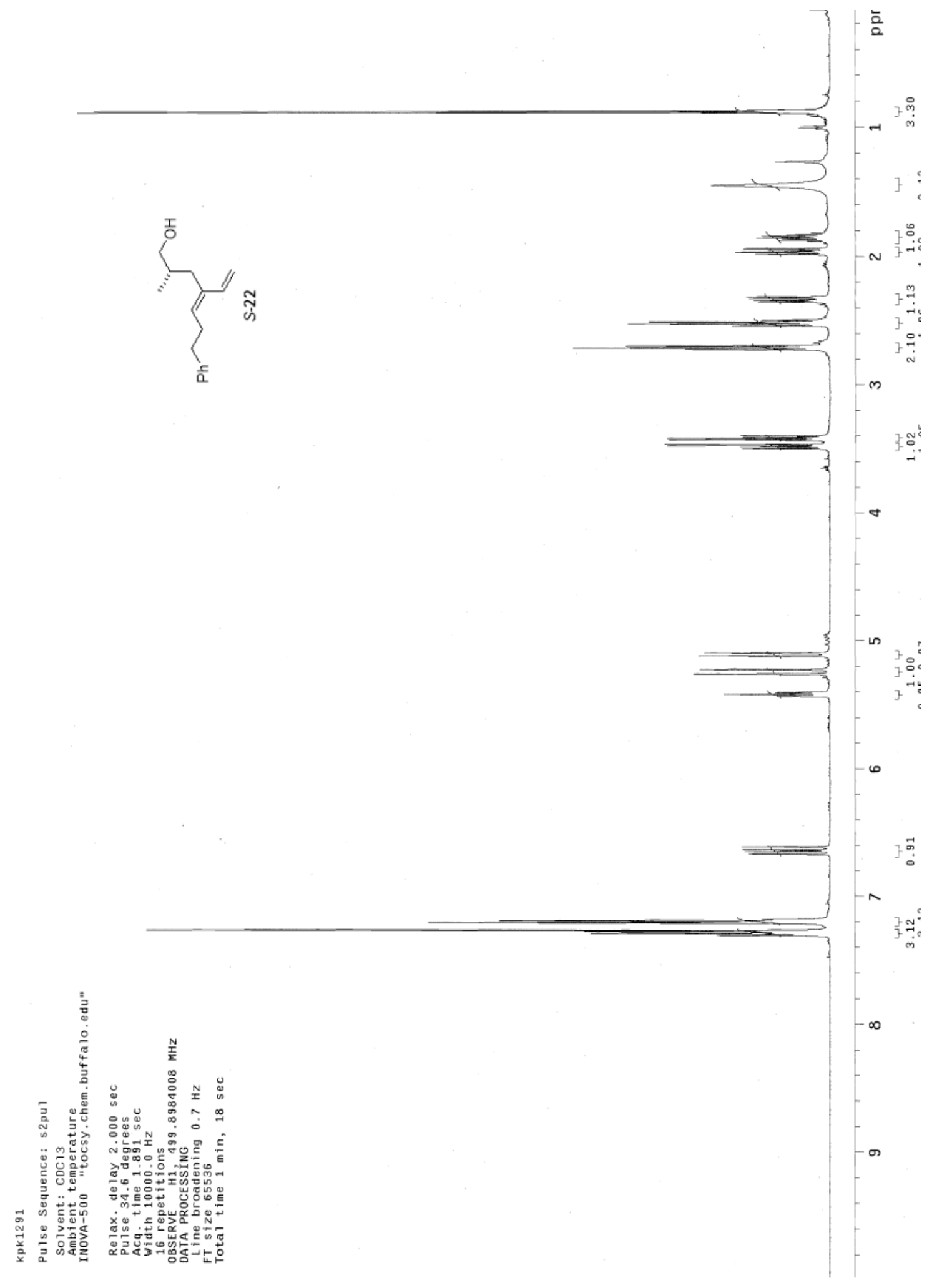




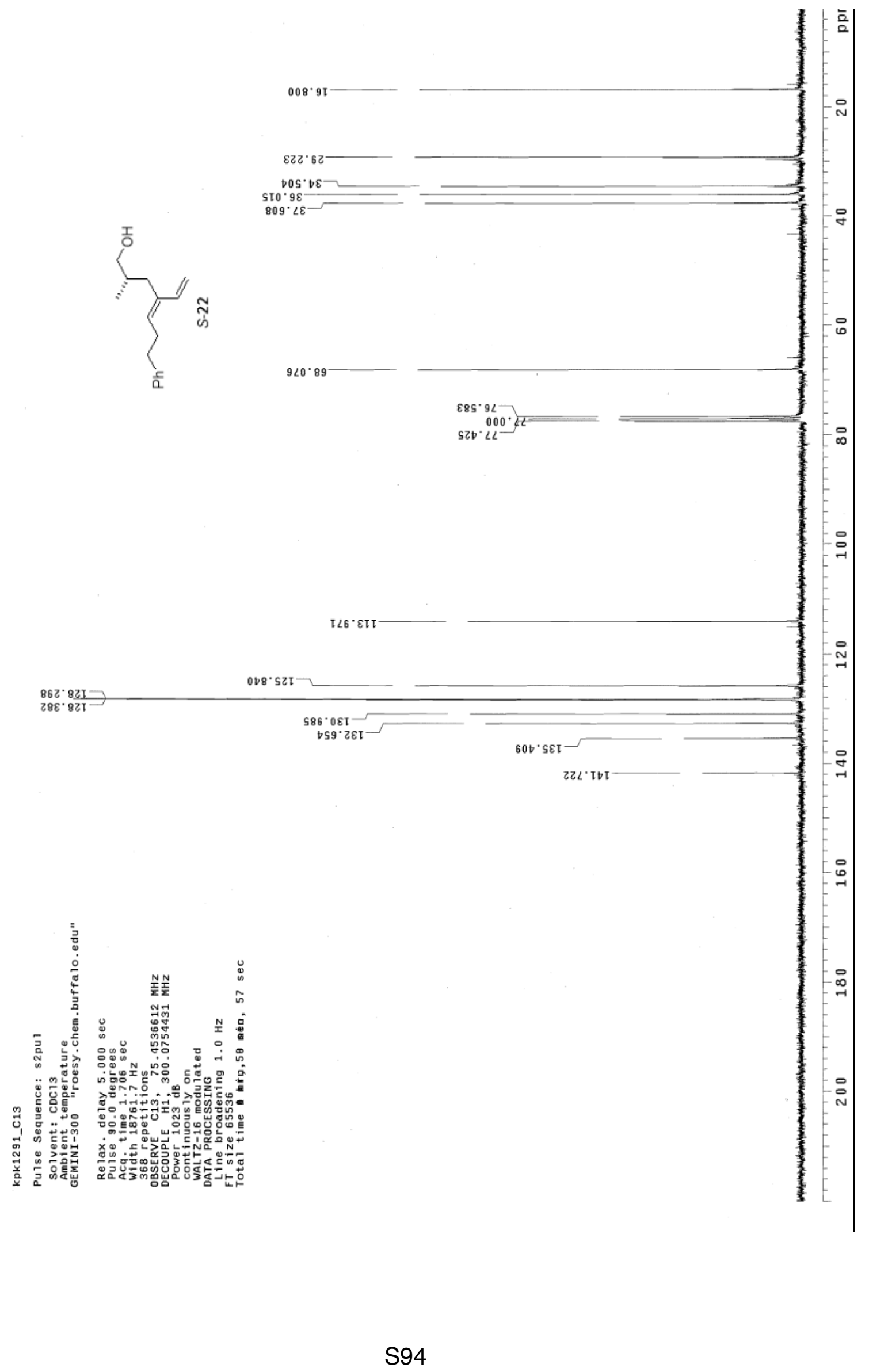




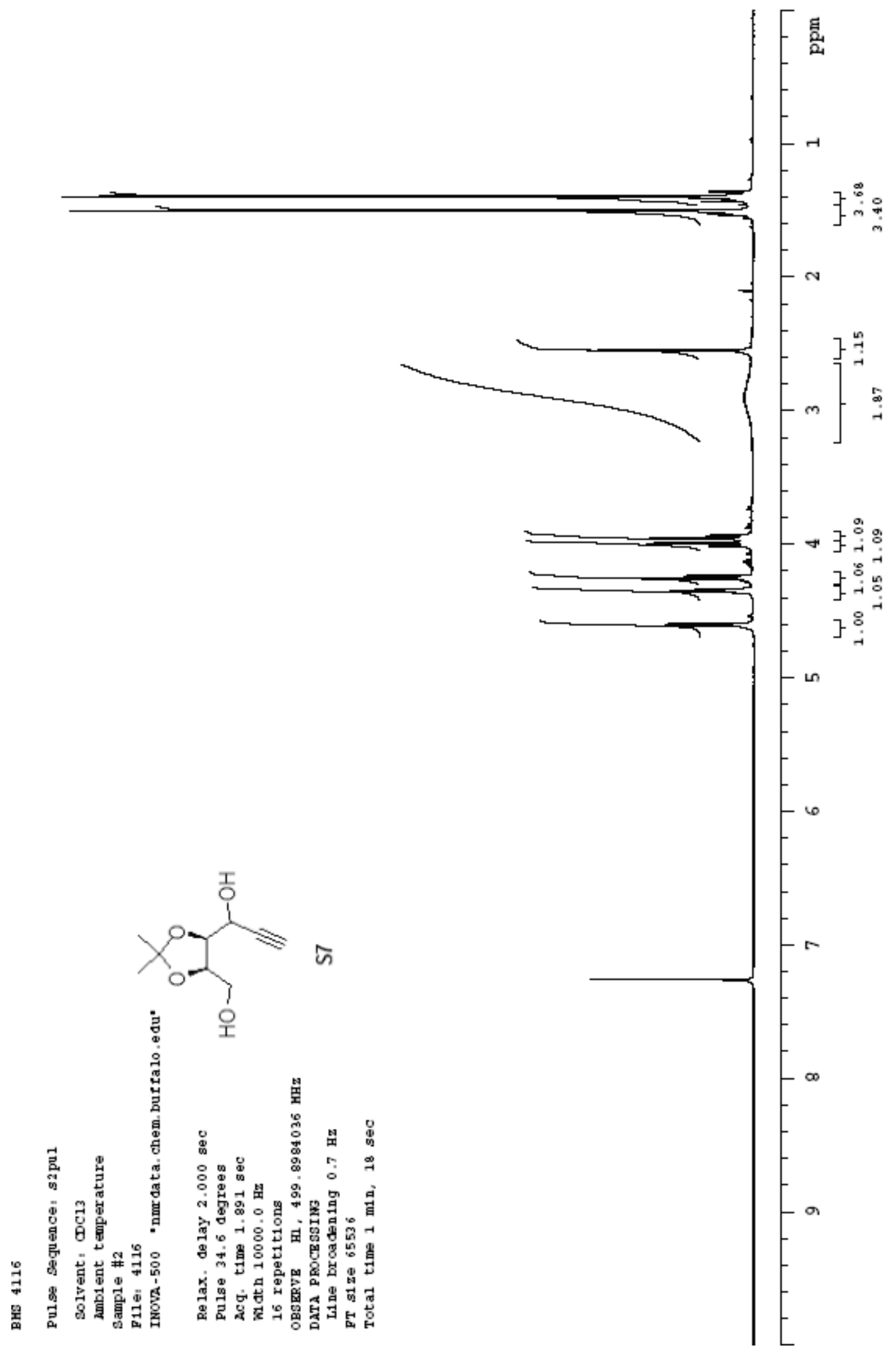




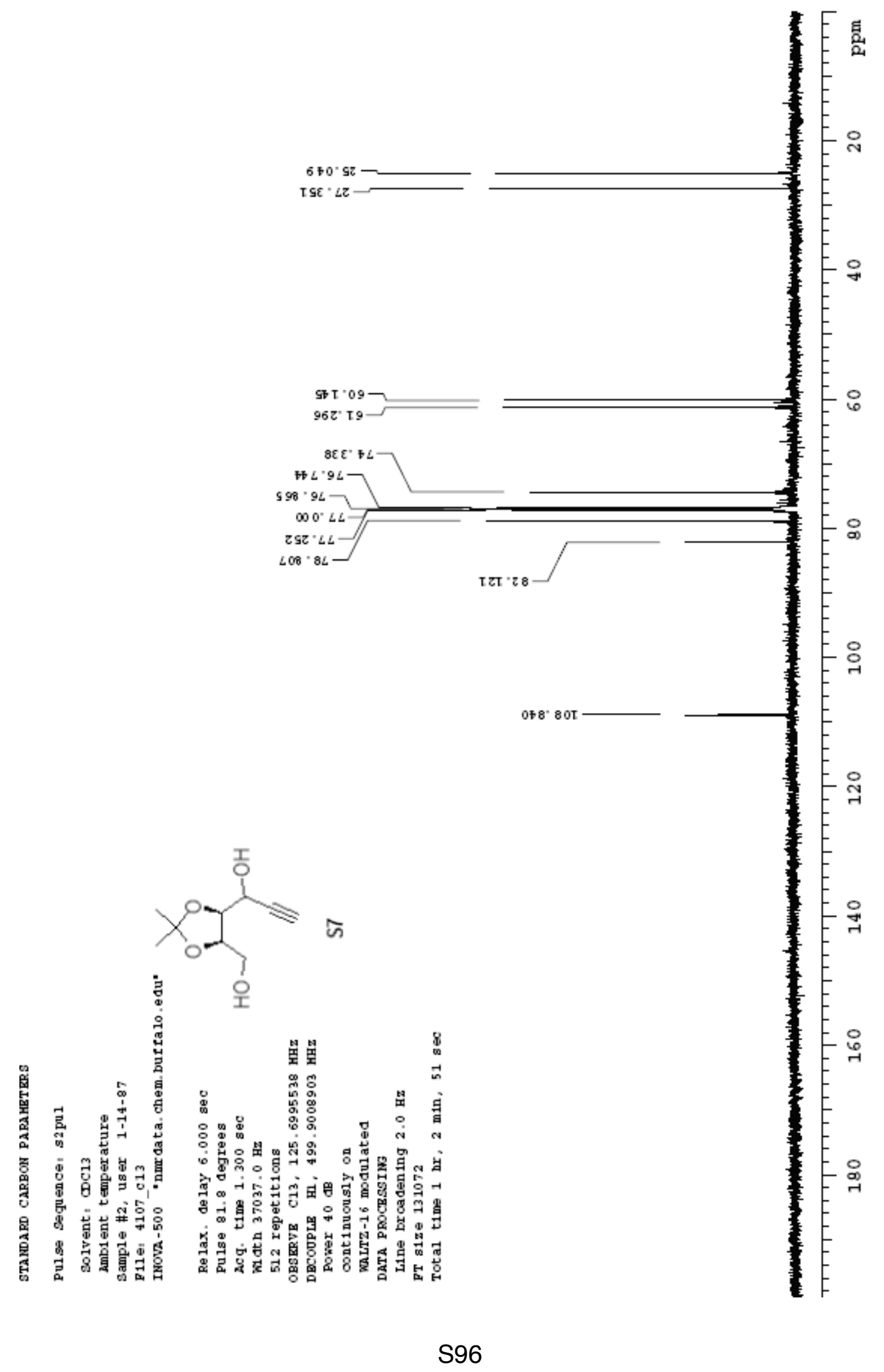




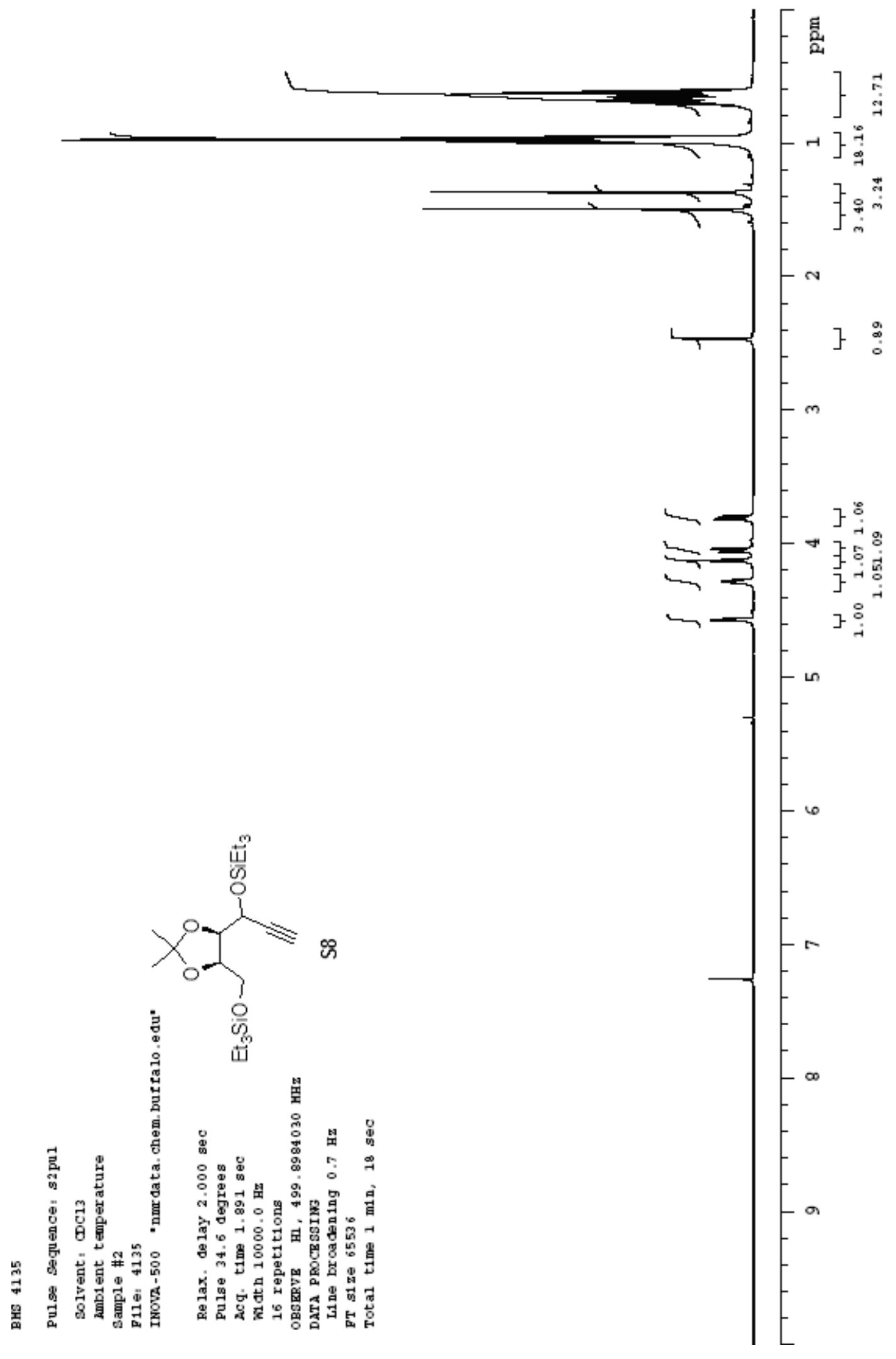




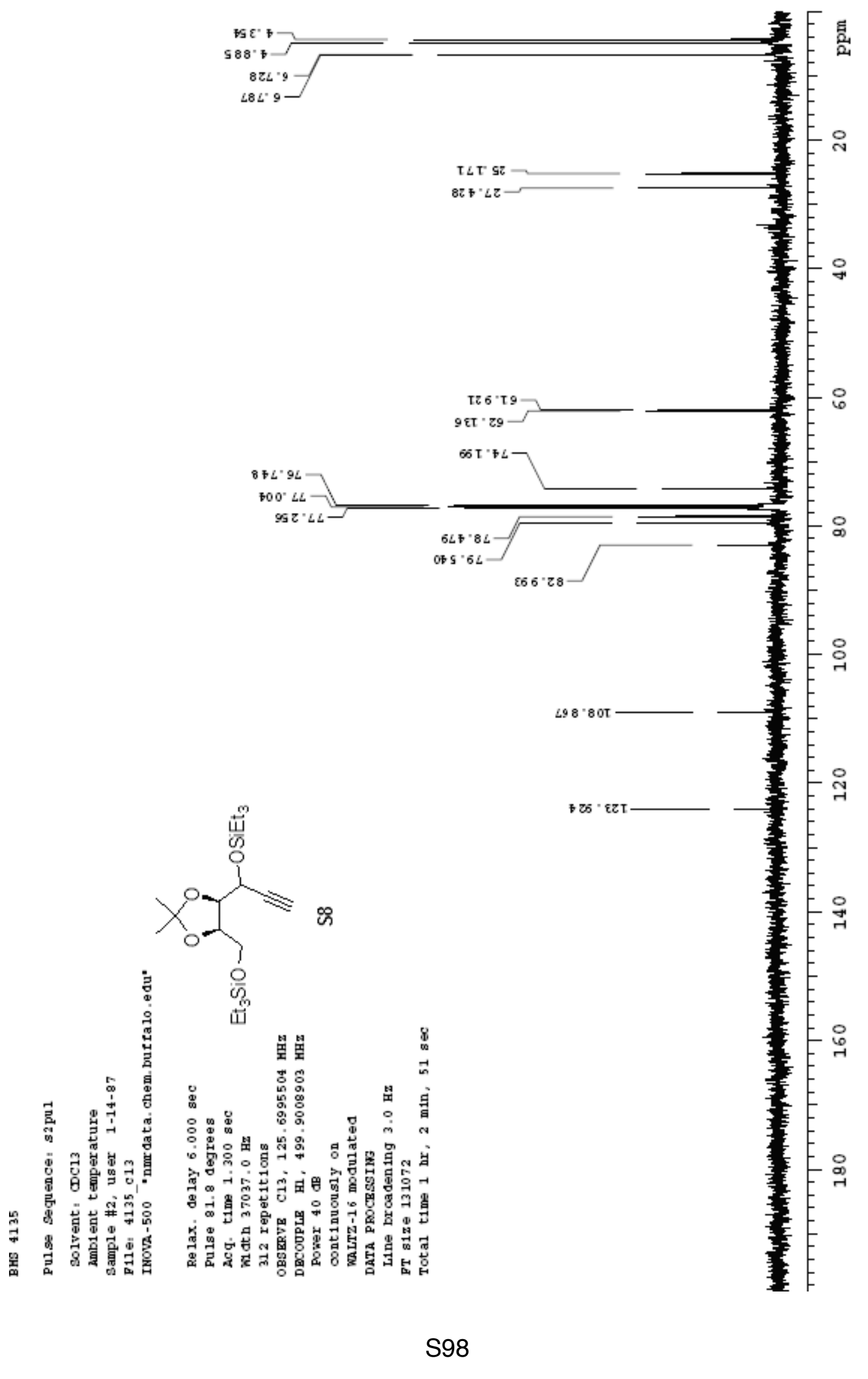




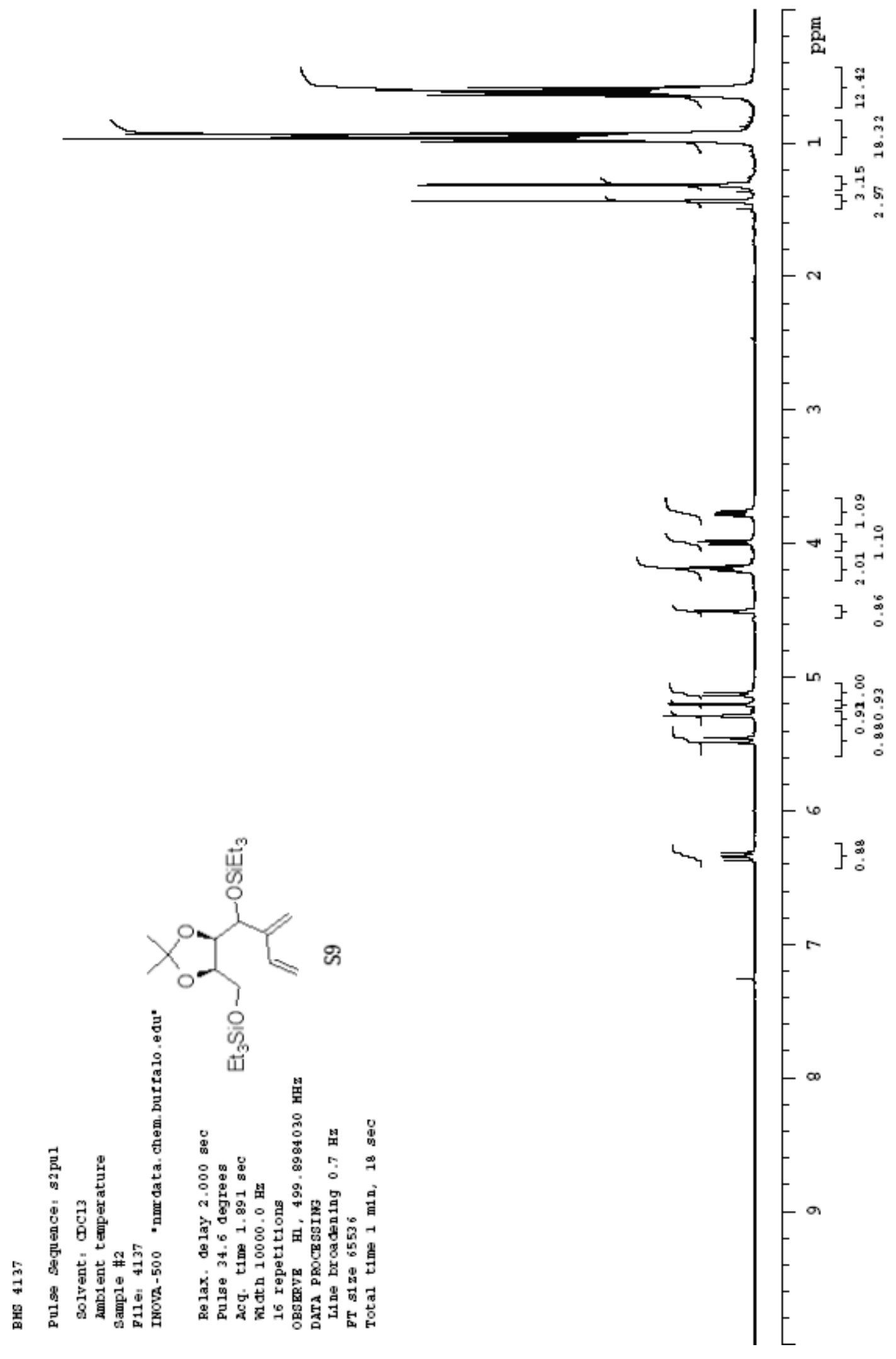




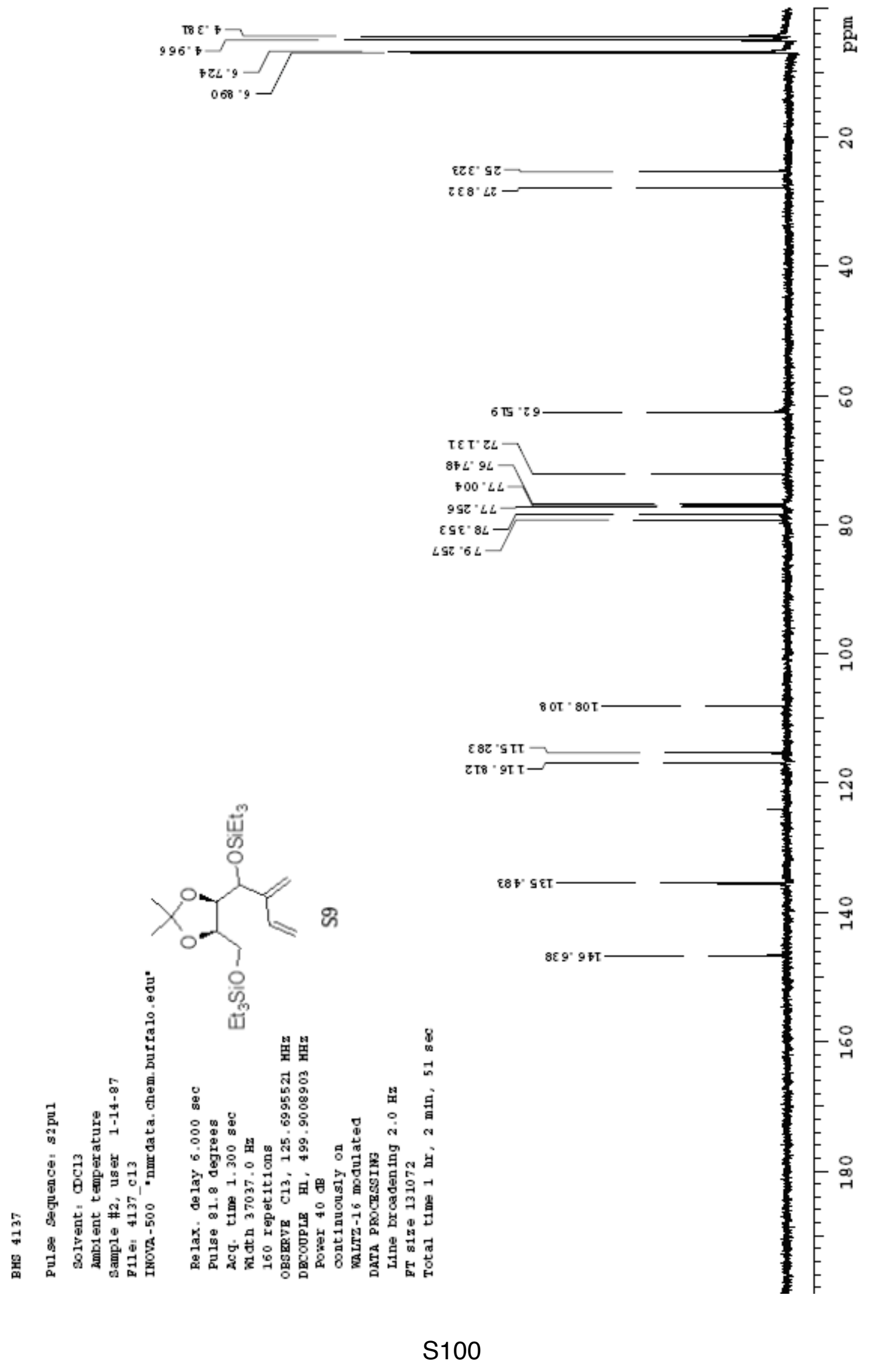




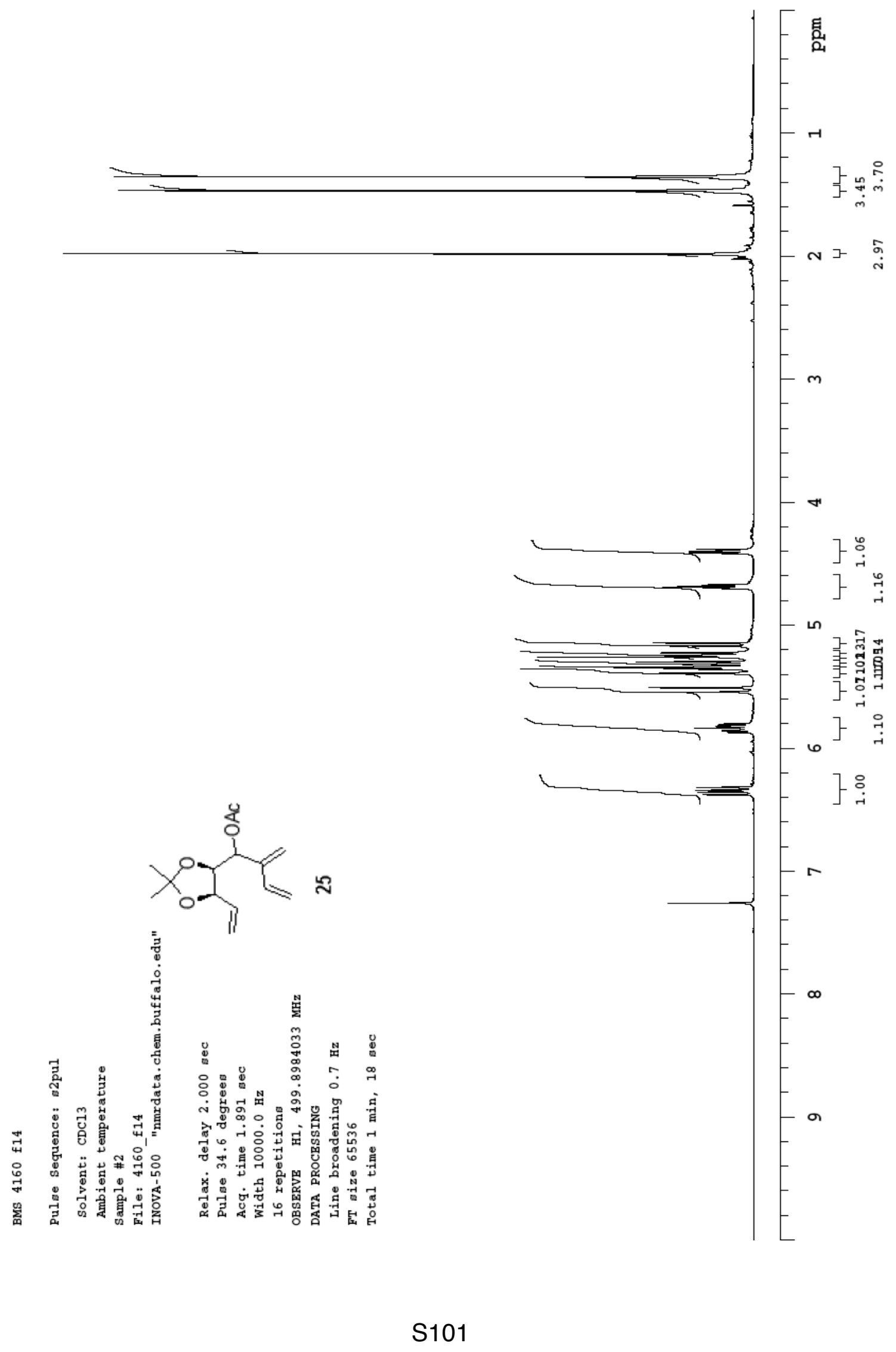




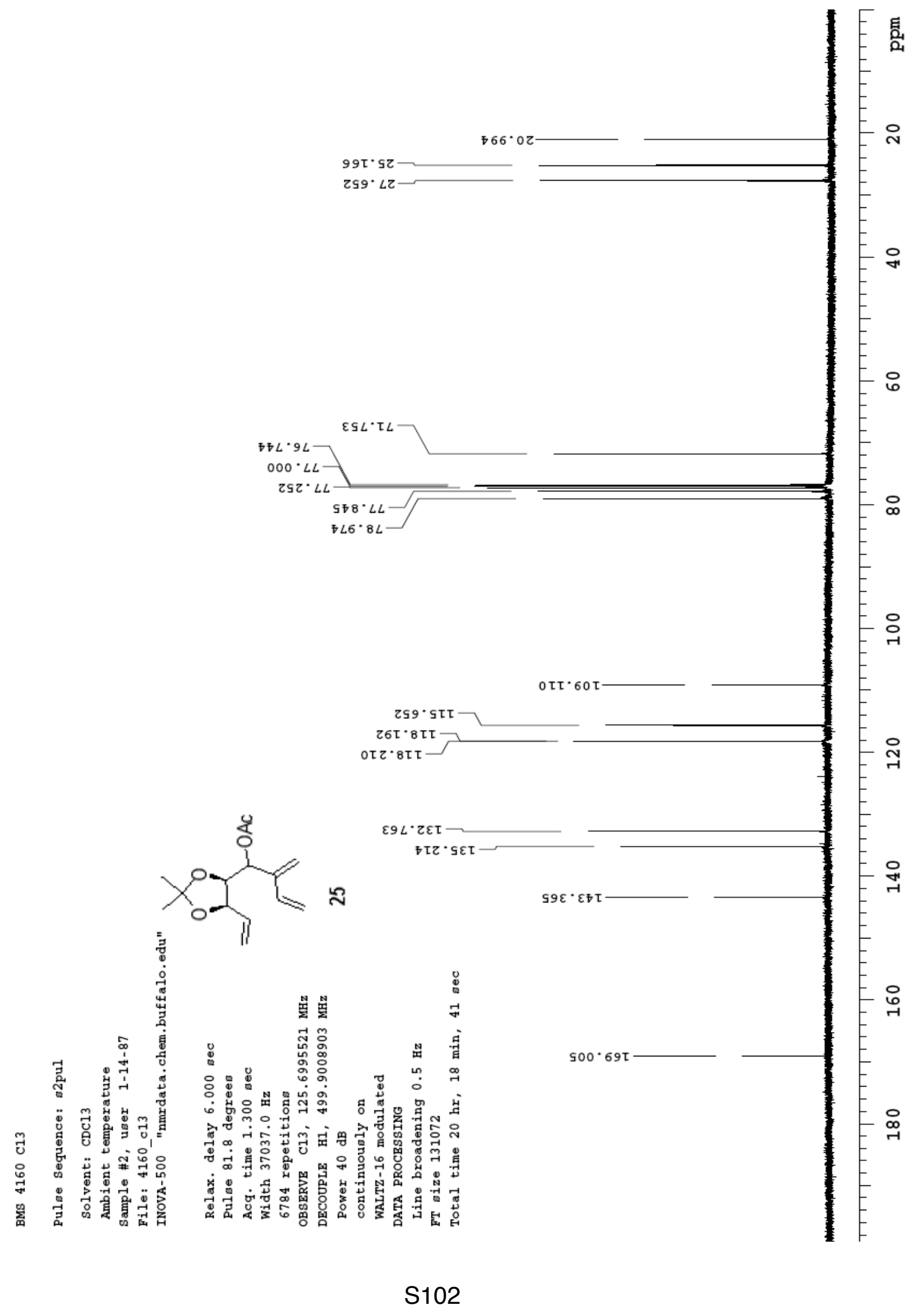




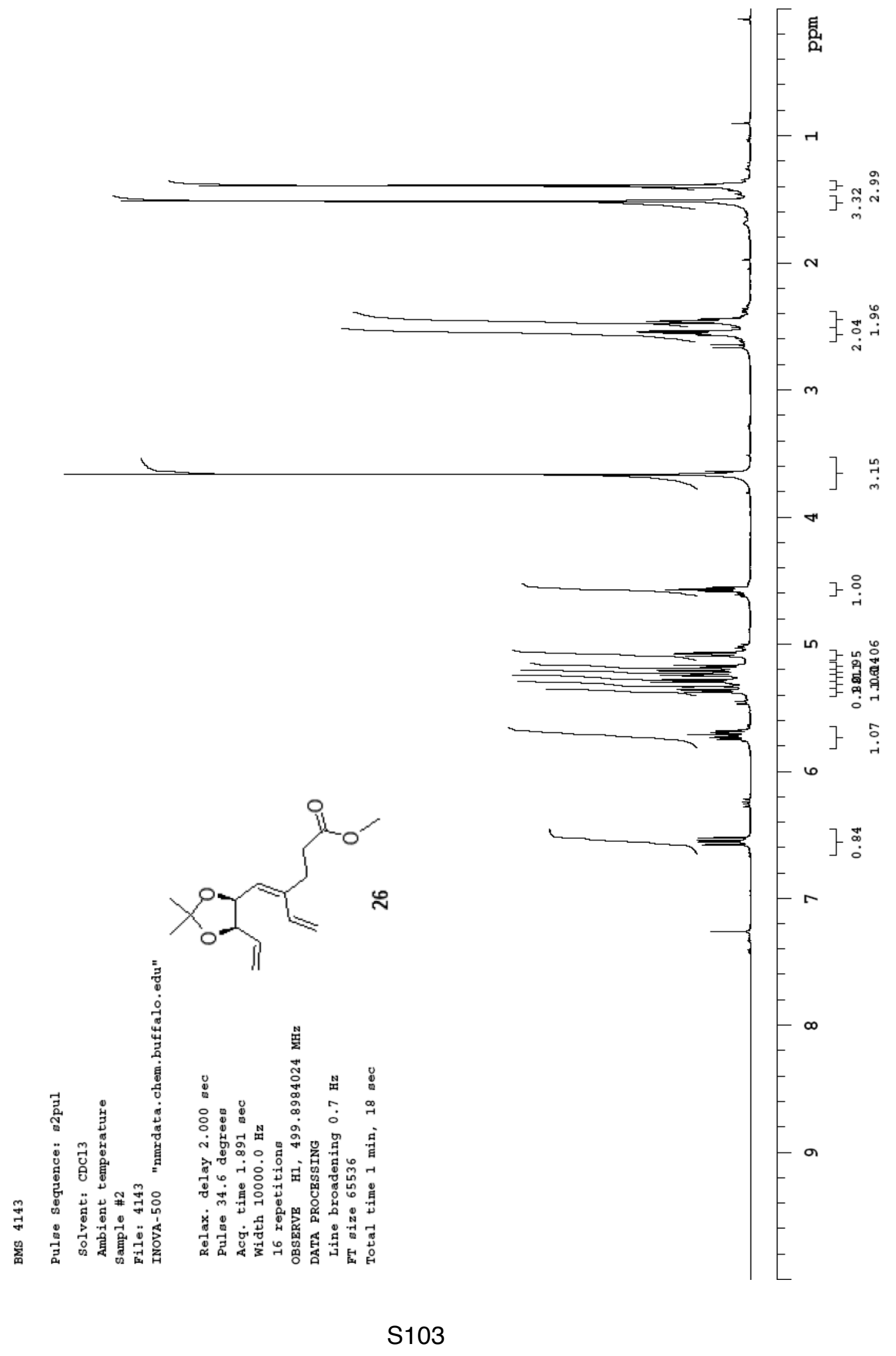



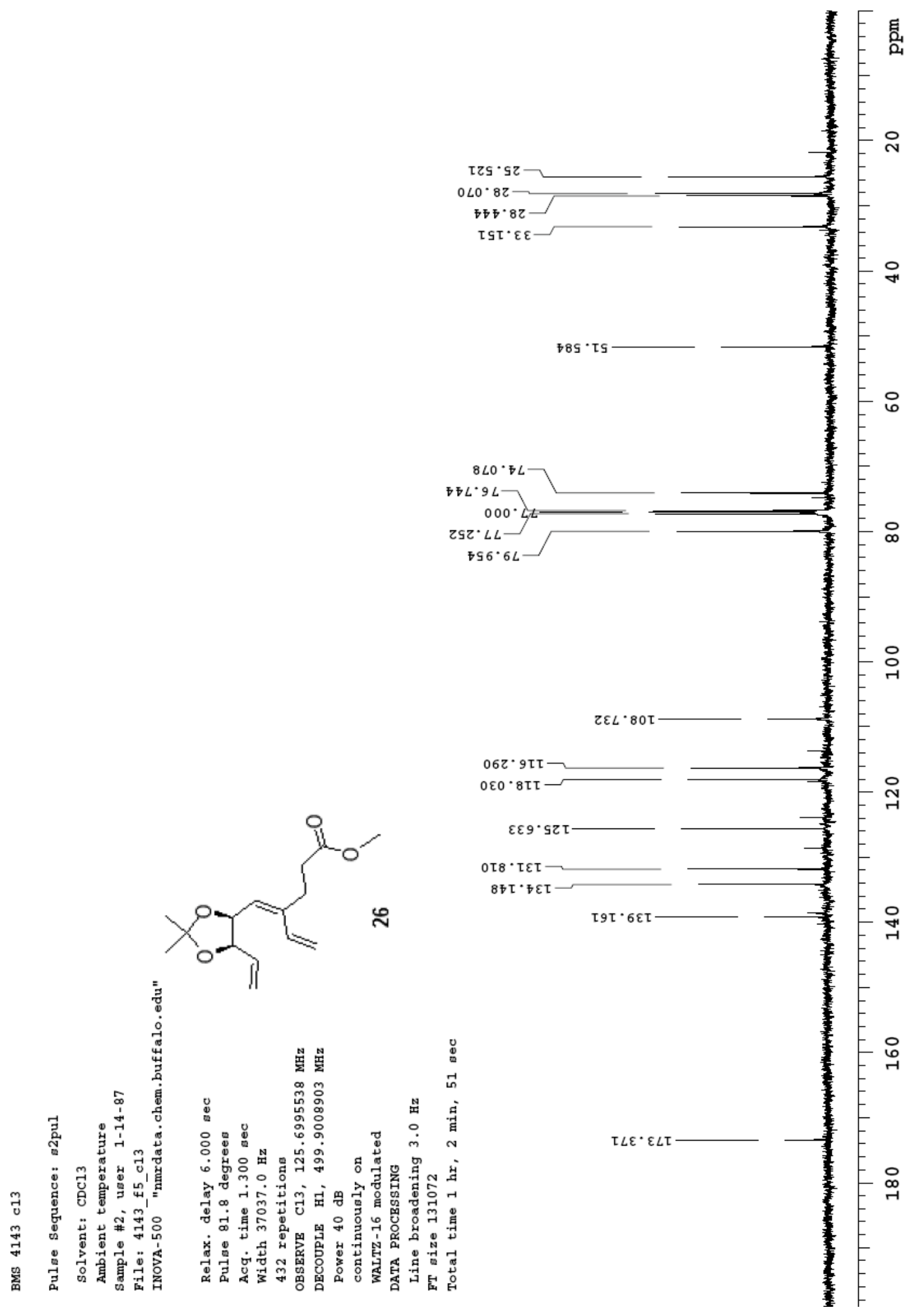


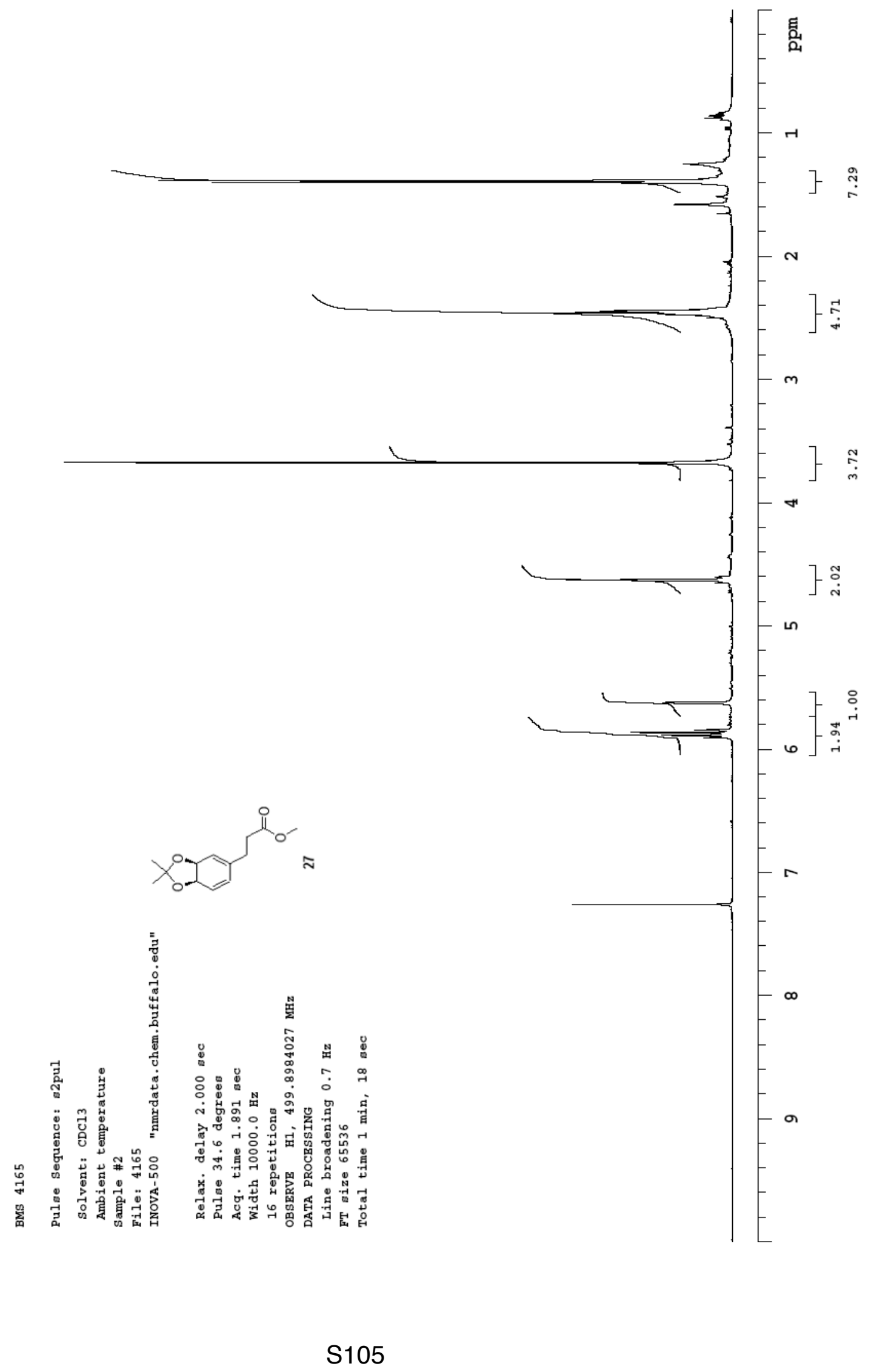




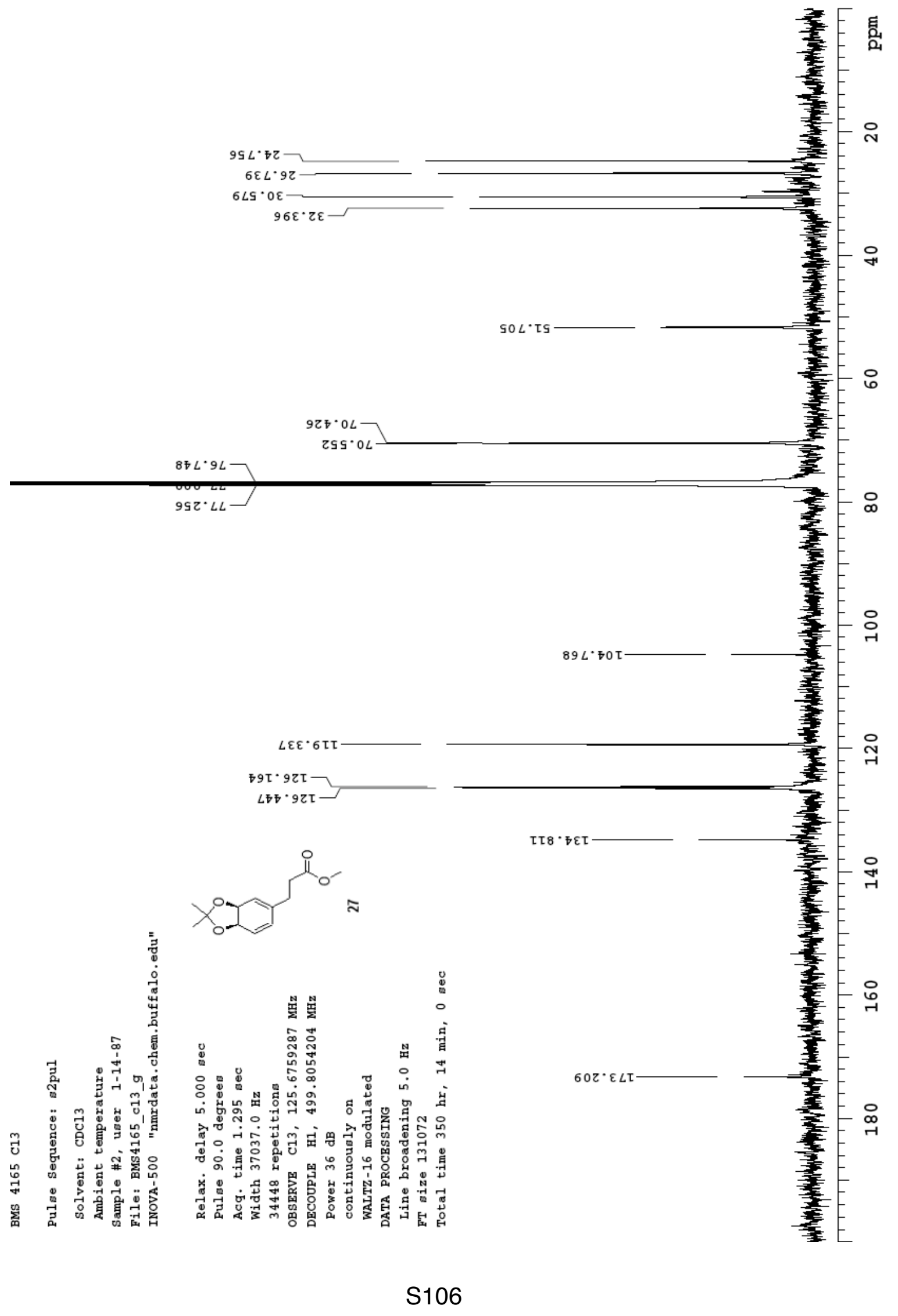

